UNIVERSIDADE DE SÃO PAULO

ESCOLA DE COMUNICAÇÕES E ARTES

RODRIGO GOMES GUIMARÃES

A voz do Outro na voz do documentário 


\section{A voz do Outro na voz do documentário}

Tese apresentada ao Programa de Meios e Processos Audiovisuais da Escola de Comunicações e Artes da Universidade de São Paulo como requisito para obtenção do título de Doutor em Meios e Processos Audiovisuais.

Área de Concentração: Cultura Audiovisual e Comunicação

Orientadora: Prof. Dra. Rosana de Lima Soares 
Autorizo a reprodução e divulgação total ou parcial deste trabalho, por qualquer meio convencional ou eletrônico, para fins de estudo e pesquisa, desde que citada a fonte.

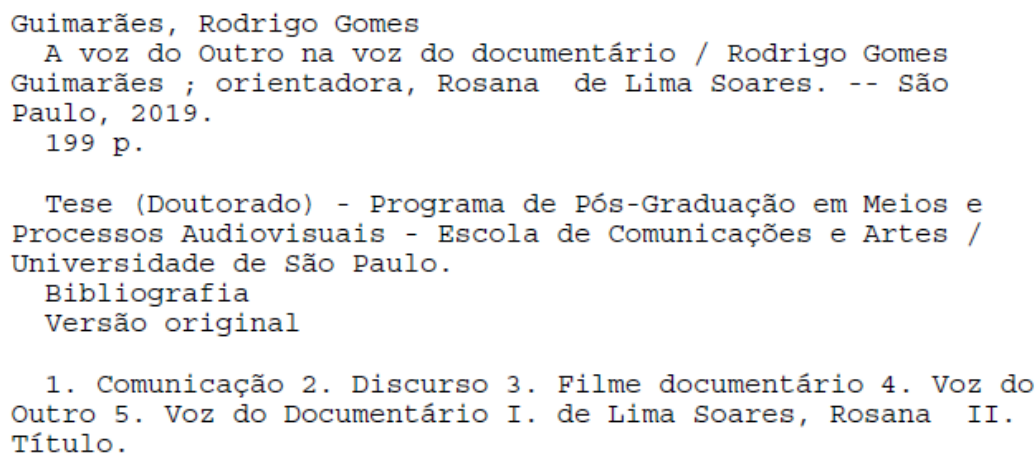

CDD 21.ed. - 791.43 
Nome: GUIMARÃES, Rodrigo Gomes

Título: A voz do Outro na voz do documentário

Tese apresentada ao Programa de Meios e

Processos Audiovisuais da Escola de

Comunicações e Artes da Universidade de

São Paulo como requisito para obtenção

do título de Doutor em Meios e Processos

Audiovisuais.

Aprovado em:

\section{Banca Examinadora}

Prof. Dr.

Instituição:

Julgamento:

Assinatura:

Prof. Dr.

Instituição:

Julgamento:

Assinatura:

Prof. Dr.

Instituição:

Julgamento: Assinatura:

Prof. Dr. Instituição:

Julgamento: Assinatura: 
A todos que se colocam a caminho de um mundo com mais justiça social e liberdade. 


\section{AGRADECIMENTOS}

À Profa. Dra. Rosana de Lima Soares, minha orientadora, que aceitou o desafio desse trabalho e foi fundamental à sua construção e realização. Sua atenção para o pensamento complexo e rigoroso, ao mesmo tempo sua dedicação ao modo como o pensamento vive como ação me deram ânimo para finalizar esta pesquisa.

Aos meus ex-professores e orientadores, Dra. Angana Chatterji e Dr. Richard Shapiro, sem os quais eu teria me tornado um pensador metafísico sem pés no chão, enquanto o que eu realmente buscava eles puderam me proporcionar: pensamentos altos e potentes em vida.

À Andrea Limberto, cuja revisão formal e teórica deste trabalho foi de alto valor para a melhor comunicação.

Aos amigos, familiares e colegas que, ao longo da vida, engajaram-se em projetos e pensamentos pulsantes comigo: eu sei quem vocês são e isso basta.

À Escola de Comunicação e Artes da Universidade de São Paulo, um lugar onde é possível pensar para e com mundos diferentes. 


\section{Resumo}

GUIMARÃES, Rodrigo Gomes. A voz do Outro na voz do documentário. 199f. Tese (Doutorado em Meios Processos Audiovisuais) - Escola de Comunicação e Artes, Universidade de São Paulo, São Paulo, 2019.

O filme documentário foi utilizado, desde seus primórdios, para representar a alteridade, as diferenças de modos de vida, cultura e pensamento. Documentaristas produziram com base em modos de trabalho variados e, dentre eles, sempre houve discussões sobre a (im)possibilidade da representação da alteridade em filmes. Nesta pesquisa, utilizamos o conceito da "voz do documentário", de Bill Nichols, para pensar sobre modos de representação da voz de Outros dentro da voz do documentário. Alargamos seu entendimento para analisar tanto modos de produção quanto de recepção em que a representação pelo documentário possa ser concebida e praticada como forma de ação pela melhoria da vida de Outros sujeitos filmados. A leitura do conceito de "voz" se deu pelas contribuições do campo da linguagem, da cultura e do cinema enquanto discurso, uma leitura baseada nos legados do pensamento crítico trazidos pelo pós-colonialismo, pós-estruturalismo, estudos culturais, feminismo e pela genealogia proposta por Michel Foucault, como abordagem metodológica. Por ser um trabalho genealógico, esta pesquisa buscou evidenciar discursos dominantes e seus Outros: discursos subalternos sobre o Outro, discursos do Outro como alteridade, discursos que são Outro dos dominantes. Nosso foco na questão da dominância priorizou os discursos produzidos por documentaristas e pensadores do documentário brasileiros, embora não tenha se limitado a eles. Os resultados indicam que há um discurso dominante no Brasil sobre a voz do Outro na voz do documentário, que é o da impossibilidade da representação dessas vozes no que elas trazem de intencionalidades para o mundo vivido. Por outro lado, encontramos pelos discursos dos filmes documentários a subalternidade na prática do documentário como intervenção direta no mundo, realizando a ressonância da voz de Outros. Indicamos que tem ocorrido uma reversão nesse sentido, pela qual a ética do documentário pode ser repensada por meio de relações entre cineastas, Outros sujeitos filmados e públicos, em que os efeitos dos filmes documentários no mundo são valorizados de maneira diferente do que na ética dominante presente, em quem o Outro é, comumente, apenas personagem de filmes. A pesquisa levanta questões teóricas e práticas para pensar filmes documentários que visem representar a voz do Outro na voz do documentário com vistas a intervir para a melhoria das condições de vida de Outros sujeitos filmados e suas comunidades.

Palavras-chave: Comunicação. Discurso. Filme Documentário. Voz do Outro. Voz do Documentário. 


\begin{abstract}
GUIMARÃES, Rodrigo Gomes. The voice of the Other in the voice of the documentary. 199f. Tese (Doutorado em Meios Processos Audiovisuais) - Escola de Comunicação e Artes, Universidade de São Paulo, São Paulo, 2019.
\end{abstract}

From its beginnings the documentary film was used to represent alterity, the differences in ways of life, culture and thought. Documentary filmmakers developed multiple modes of work and within these there have always been discussions about the (im)possibility of the representation of alterity in films. In this research, we use Bill Nichols' concept of the "voice of the documentary" to reflect on ways of representing the voice of Others within the voice of the documentary. We extend such concept to analyze both the modes of production and reception by which representation in the documentary can be understood and practiced as a form of action for the improvement the lives of Other filmed subjects. Our understanding of the concept of "voice" comes from the contributions of the field study of language, culture and cinema as discourse, a perspective based on the legacies of critical thinking brought about by postcolonialism, poststructuralism, cultural studies, feminism and genealogy in consonance with what is proposed by Michel Foucault, as a methodological approach. Intended as a genealogical work, this research sought to highlight dominant discourses and their Other subaltern discourses considering both the Other as otherness and discourses that are Another of the dominant. Our focus on the dominance issue prioritizes the discourses produced by Brazilian documentary filmmakers and theorists of documentary, though not limited to them. The results indicate that there is a dominant discourse in Brazil about the voice of the Other in the voice of the documentary that is of the impossibility of the representation of these voices as they bring intentionalities toward the lived world. On the other hand, we found in the discourses on documentary film the subalternity of the practice of the documentary as a direct intervention in the world, including the resonance of the voice of Others. We point out that a reversion must be taking place in this direction, as the documentary ethics is reviewed in the relations among filmmakers, other filmed subjects, and public, by which the effects of documentary films in the world will be differently valued than they are today in the present dominant ethic where the Other is just a movie character. The research raises theoretical and practical questions about documentary films aiming to represent the voice of Others in the voice of documentary with a will to intervene and improve the living conditions of Other filmed subjects and their communities.

Keywords: Documentary. Communication. Discourse. Documentary Film. Voice of the Other. Voice of the Documentary. 


\section{Sumário}

Introdução

Como utilizamos a genealogia nesta pesquisa

1.1 - O cinema nasce do encontro com Outros

1.2 - O Outro e seus duplos

1.3 - Caminhando do Outro para o documentário como portador de uma voz 
documentário

Considerações finais: para quê serve a representação do Outro? 


\section{Vozes-Mulheres}

A voz de minha bisavó

ecoou criança

nos porões do navio.

ecoou lamentos

de uma infância perdida.

A voz de minha avó

ecoou obediência

aos brancos-donos de tudo.

A voz de minha mãe

ecoou baixinho revolta

no fundo das cozinhas alheias

debaixo das trouxas

roupagens sujas dos brancos

pelo caminho empoeirado

rumo à favela.

A minha voz ainda

ecoa versos perplexos

com rimas de sangue

e

fome.

A voz de minha filha recolhe todas as nossas vozes recolhe em si as vozes mudas caladas engasgadas nas gargantas.

A voz de minha filha recolhe em si

a fala e o ato.

O ontem - o hoje - o agora.

Na voz de minha filha

se fará ouvir a ressonância

o eco da vida-liberdade.

Conceição Evaristo 


\section{INTRODUÇÃO}

\section{Os filmes documentários e seus Outros}

Esta pesquisa busca sondar o filme documentário como portador de vozes de Outros - os sujeitos filmados do documentário. Se o filme documentário passou em vários países por momentos em que pouco se questionava sua relevância para fazer ressoar vozes dos sujeitos filmados, especialmente quando nos anos 1960 o som direto, sincrônico à imagem, se tornou possível graças a avanços tecnológicos, por outro lado parece que o encanto com essa possibilidade de ecoar e fazer ressoar vozes se desfez. No Brasil, buscar por pesquisas e trabalhos que versam sobre a voz do Outro no documentário é encontrar, repetidamente, afirmações da impossibilidade da representação do real, do Outro, ou do pensar o filme documentário como meio de intervenção no mundo. Se já houve épocas em que, de diferentes maneiras, fazer documentários era uma maneira de mudar o mundo, hoje, ao buscar localizar essas discussões no Brasil, acabamos nos deparando com um arcabouço de pesquisas, textos, entrevistas, artigos dos nomes mais renomados do documentário, a nos dizer que o filme documentário não deve fazer nada sobre o mundo.

Poderíamos concordar e, com isso, nossa pesquisa não teria utilidade. Se fosse um fato inquestionável que o filme documentário não tem efeitos, intencionais ou não, sobre o mundo, sobre aspectos de uma sociedade que o filme venha a discutir, de que valeria continuar a fazer documentários sobre contextos sociais, culturais, políticos, econômicos, e outros? Por que é que o filme documentário, que já foi por diversas vezes no passado, pensado como um importante instrumento de mudança social, ou de crítica social visando mudanças, hoje é alvo de um conjunto de discursos e de práticas institucionais que parecem dizer: "Olhe, deixe de lado essa coisa de querer criticar, de querer ensinar algo, de querer mudar alguma coisa do mundo. Apenas faça filmes bons”. Se fosse enveredar pelo autobiográfico, pela autoetnografia, pela autorepresentação ou outro método, como realizador de documentários eu teria muitas dessas frases e histórias a contar. Mas decidi por outro caminho. Minha questão, como sujeito engajado no mundo em que vivo, é como me relaciono com ele, como sou (re)produtor das culturas que me formam, como minha atuação como pensador, ativista, pesquisador e documentarista é sempre resultado e resulta na formação da sociedade em que vivo. Uma pesquisa é mais rica e mais útil se 
feita de dentro e no aprofundamento das questões trazidas pela prática a que se refere. Uma pesquisa distanciada da prática do filme documentário, feita por pessoas que não são praticantes, tende necessariamente a reproduzir esse lugar do documentário como objeto distante. Por outro lado, uma prática do filme documentário por documentaristas engajados demais num modo de fazer, pode reproduzir também esse modo como modelo. O que não estamos aqui a buscar estabelecer é, justamente, um modelo. Essa pesquisa parte do pressuposto de que se o mundo é o lugar em que o documentarista busca produzir seus efeitos, e se busca isso sendo aliado de Outros sujeitos filmados, não pode haver modelos, fórmulas para o filme documentário. Ao mesmo tempo, isso não quer dizer que então vale tudo. Pelo contrário, nossa responsabilidade para com o mundo sendo a primeira, nossos estudos e práticas devem visar melhorar nossas interações com o mundo e sempre estar atentos a estas.

Não há modelos para o filme documentário que queremos. E não acreditamos que os filmes documentários que buscam intencionalmente e com rigor produzir efeitos para a melhoria da vida de Outros sejam necessariamente melhores ou mais valiosos de alguma forma. Ainda assim, reconhecemos que os filmes documentários que visam intervir no mundo na defesa das possibilidades de vida de Outros são aqueles que nos interessam aqui, e esse interesse não é - desinteressado. Acreditamos que nenhuma pesquisa - talvez nenhuma ação humana - seja desinteressada. Nesse sentido, porque estamos interessados em pensar o filme documentário como um meio de intervenção no mundo? Por que ter esse enfoque, e não um enfoque no filme documentário como entretenimento, por exemplo? Justamente porque o documentário como entretenimento, inclusive um entretenimento dos escolarizados, onde filmes se reportam a outros filmes, onde podemos ter conversas filosóficas e antropológicas sobre linguagem, representação, esses filmes e os acadêmicos que os discutem têm lugar hoje garantido, ao menos no Brasil. No entanto, nos últimos anos há também o ressurgimento de produções sobre ou pelos Outros que falam de questões do mundo que afligem muitas pessoas. São documentários sobre negros feitos por negros, de indígenas feitos por indígenas, de LGBTs por LGBTs. Mas não é só isso. Os movimentos sociais de luta por direitos e por mudanças sociais mais radicais também demonstram, cada vez mais, que a solidariedade não vive somente de um grupo para membros desse mesmo grupo. As redes de apoio entre movimentos criaram a noção e a prática - que não é de hoje, mas é reinventada - do aliado. Aquela pessoa que não é membro de um grupo, no entanto de seu lugar na vida social tem seu papel, tem como intervir também como aliado. Pois as dominações que colocam sujeitos 
em posições subalternas atravessam todos os sujeitos, de diferentes maneiras é certo, mas sempre o fazem. Talvez a questão do filme documentário hoje, se estiver conectado com as mudanças sociais em curso, seja se propor a pensar e praticar modos de orquestrar vozes, a como se colocar em meio a conjuntos de possibilidades de ação social. Colocarse estrategicamente, num jogo de vozes que não pára de mudar, pois o mundo não pára e é em última instância imprevisível. Contra uma paralisação da ação pela descoberta de que todos somos Outros, até de nós mesmos, urge pensar nossa ação como tendo que se munir ainda mais de relações, de leituras do mundo que embora sempre parciais, são mais ou menos efetivas em razão de como nos dispomos a ouvir e a produzir o mundo com Outros. Nossa pesquisa sobre o filme documentário se justifica na ética e na política de produzir um mundo que melhore nossas relações, tendo o filme documentário como um meio e não como um fim em si mesmo. O objetivo da pesquisa é relacionar a produção da “voz do documentário” às (im)possibilidades de representação das vozes de “Outros” em filmes documentários.

\section{Método}

Esta pesquisa tem a genealogia foucaultiana como sua base metodológica, e essa seção se esforçará para, em primeiro lugar, responder à seguinte pergunta, com todo o horror e violência que a resposta desperta e rememora em seu autor e provavelmente em alguns futuros leitores: o que é genealogia, no sentido usado por Michel Foucault em seus trabalhos? E por que isso é de certo modo difícil, nos traz memórias de horrores e violências? Se não fosse por qualquer outra coisa, simplesmente pela realidade de que a genealogia de Foucault não é um método no sentido científico do termo: um sistema fechado de regras de abordagem que garante retornos em termos de uma dicotomia verdadeiro/falso, ou então se prova inadequado por causa de falhas na aplicação, isto é, mostra o cientista como falho em sua abordagem. A genealogia foucaultiana não está preocupada com o método científico como uma abordagem unívoca, os fatos não aparecem como fatos como na tradição positivista, mas como “acidentes” (FOUCAULT, 1977) que requerem interpretação parcial e que recortam acontecimentos. É um trabalho “meticuloso e pacientemente documental” (FOUCAULT, 1977) que busca dar lugar, através de uma leitura atenta de produções socioculturais, a eventos como parte e processo de outros eventos, onde a recontagem da história não é uma busca por começos, já que o que o genealogista encontra no início dos acontecimentos, das coisas, “não é a 
identidade inviolável de sua origem; é a dissensão de outras coisas. É disparidade” (FOUCAULT, 1977). Genealogia não é esse novo método que nos libertará e finalmente chegaremos à verdade. Não procura isso. No entanto, também não é simplesmente outro método disponível que nos permite resultados diferentes. É a prática de deixar a questão dos resultados - a história que é contada, multiplamente originada - o mais próximo possível dos sistemas de pensamento que operam no presente, apenas para forçar a busca de entendimentos do presente que podem mudá-lo, porque ficamos com um presente que é ele mesmo multiplicado e contestado. A genealogia é, ao mesmo tempo, uma compreensão erudita da multiplicidade do passado, com uma atenção dirigida às condições de dispersão da formação do presente, com o objetivo de proporcionar entendimentos que possam mudar o presente. Está acima de tudo preocupada com o presente, enquanto ainda está atenta para não discutir com o passado como se fosse aquilo que explica totalmente o presente. A questão, para o genealogista, é abrir possibilidades de vida no presente. É um trabalho inerentemente posicionado no tempo, embora para isso busque aberturas, pois o presente é relativamente aberto e incomensurável, em última instância. Genealogia não é dar uma palavra final sobre o tempo.

Nesse sentido, praticar a genealogia e produzir filmes contam como atividades muito diferentes. Pois muitos filmes, mesmo sem a intenção de seus produtores, são recebidos por públicos como afirmações finais sobre o tempo. Afirmações sobre o que ocorre com Outros numa linha do tempo do filme, ou mesmo como no caso do documentário, no tempo recortado de uma vida. Filmes têm que lidar o tempo todo com a possibilidade (re)criar ou (re)produzir fechamentos sobre Outros representados nos filmes.

Na genealogia, não há explicação final. A história do presente que ela clama não é para corrigir o presente, porque tal possibilidade assume a história como intencional, como tendo um desígnio e, como tal, denuncia um "sistema de pensamento" específico que Foucault (1972) chamou de "história contínua". Esse é uma das epistemes ${ }^{1[1]}$ do nosso tempo, ainda dominante embora já contestado de diversas formas, especialmente nas ciências humanas pelo pós-estruturalismo, pós-colonialismo, feminismo, e na filosofia não-metafísica de Nietzsche, Heidegger, Deleuze, entre outros. Os legados de

\footnotetext{
1 “A análise das formações discursivas, das positividades e do saber em suas relações com as figuras epistemológicas e as ciências é o que se chamou, para distingui-la das outras formas possíveis de história das ciências, de análise da episteme” (FOUCAULT, 1972).
} 
pensamento dominante no Ocidente e num mundo onde a globalização introduz a dominância desses legados ocidentais, colocou a metafísica como sistema dominante de pensamento que tem na identidade do Mesmo, sua fórmula básica para o saber e para práticas sociais. A história contínua é ainda a base epistemológica dominante nas sociedades ocidentais e em globalização. Nela, as ordens do Mesmo, do Humano enquanto ser universal, e da História enquanto linha evolutiva unívoca, são a episteme do sistema de pensamento dominante. O pensamento do Outro, do radicalmente diferente, não tem lugar nesse pensamento dominante, a não ser como um Outro com potencial para o Mesmo, para o qual falta a identidade do Mesmo. Ser Outro, para a episteme dominante, é ser o Mesmo em potencial, ou então é não ser, não existir.

Sob essa episteme, a representação do Outro é acessível, é não-problemática, ou quando se apresenta como problema, é porque já se tem a solução. A alteridade não consegue se apresentar como diferença incomensurável. É nessa linha que muitos filmes documentários foram realizados nas primeiras décadas do século passado. Falando sobre o filme que é considerado por muitos como sendo o primeiro documentário da história, Nanook (1922), o diretor Robert Flaherty relata suas intenções:

Eu queria mostrar os inuit, e queria mostrá-los não do ponto de vista da civilização, mas como eles próprios se vêem. Como nós, o povo... Dei ao meus trabalhos um sentido etnográfico. Pode-se descobrir uma graça, uma dignidade, uma cultura, um refinamento que ignoramos, nesses povos que as circunstâncias colocaram fora das condições habituais. Minha intenção era trazer de lá uma pintura exata e favorável (FLAHERTY apud GERVAISEAU, 2012, p. 74).

A prática de falar pelo Outro era comum na etnografia, que era incentivada como atividade realizadora do domínio colonial europeu sobre outros povos. A etnografia, no entanto, tinha uma dupla face: falar pelo Outro poderia também querer dizer criar representações do Outro como digno em si mesmo, sem necessidade de ser tutelado por um poder colonial. Como prática do documentário, falar pelo Outro se concretizou em filmes muito diferentes, alguns românticos como os de Flaherty, e filmes que produziram, no outro extremo, o Outro como aberrante, aterrorizante, ou inerentemente falho. Nesse legado de falar pelo Outro, houve documentários que romperam com esse imperativo, no entanto. O primeiro deles talvez tenha sido Terra Sem Pão (Direção Luis Buñuel, 1933), 
em que a narração em voice-over é construída de modo a satirizar a voz de autoridade das narrações em documentários, embora muitos públicos não tenham entendido a crítica, por estarem acostumados a documentários que falavam sobre/pelo Outro. Esse foi o primeiro filme a revirar a linguagem do documentário de ponta-cabeça, e a produzir uma reflexão sobre a ética do filme documentário, sobre o modo como a representação do Outro pode ser uma forma de violência. A história do filme documentário, portanto, teve desde seus primórdios uma preocupação com os efeitos da representação, embora dominantemente as primeiras décadas tenham tratado a representação do Outro como possível, gentil e desejável.

No pensamento dominante no Ocidente, a história caminha somente em linha reta e única, do passado ao presente ao futuro. Uma teleologia do mundo seria possível, a história pode assim ser contada como progressiva e chegando a unidades definidas do Ser. Essa teleologia de certa forma tanto interpreta o pensamento dominante quanto lhe dá um discurso de autolegitimação e autoperpetuação. Mas como sempre na história, sob a perspectiva de um genealogista, Foucault apontava que isso já estava mudando, mas que ainda havia muito a ser repensado e transformado com relação à epistemologia e à possibilidade do pensamento sobre a não identidade, sobre o Outro como possibilidade do mundo vivido, como possibilidade de nova abertura para o pensamento e para as diferenças. A genealogia busca explicitar o que é esquecido quando se conta a história de modo finalista, com uma voz universal ou unívoca, ao escavar as linhas esquecidas da memória e das histórias dominantes que chegaram ao presente. Foucault conta que o modo dominante, metafísico, de pensar a história tem passado por mudanças e novas aberturas para o Outro sempre presente em toda narrativa:

Essa mutação epistemológica da história ainda não está completa. Mas isso também não é de origem recente, já que sua primeira fase pode sem dúvida remontar a Marx. Mas demorou muito para ter muito efeito. Mesmo agora - e isso é especialmente verdadeiro no caso da história do pensamento - não tem sido nem registrado nem refletido, enquanto outras transformações mais recentes - as da linguística, por exemplo - foram. É como se fosse particularmente difícil, na história em que os homens refazem suas próprias ideias e seu próprio conhecimento, formular uma teoria geral da descontinuidade, de séries, de limites, unidades, ordens específicas e autonomias e dependências diferenciadas. Como se, naquele campo em que nos acostumamos a procurar origens, a empurrar de volta 
cada vez mais a linha de antecedentes, para ir reconstituindo tradições, seguindo curvas evolutivas, projetando teleologias, e para ter constante recurso a metáforas da vida, sentimos uma repugnância particular em conceber a diferença, em descrever as separações e dispersões, em dissociar a forma tranquilizadora do idêntico. Ou, para ser mais preciso, como se achássemos difícil construir uma teoria, tirar conclusões gerais, e até mesmo tirar todas as possíveis implicações destes conceitos de limiares, mutações, sistemas independentes e limitações da série - na maneira em que eles foram usados de fato pelos historiadores. Até parece que tínhamos medo de conceber o Outro no tempo do nosso próprio pensamento (FOUCAULT, 1972, pp. 11-12, tradução nossa).

A histórica contínua, segundo Foucault, é uma episteme do nosso presente. Ela marca o pensamento de modo a invisibilizar qualquer alteridade que se apresente como radical. As diferenças de pensamento, de modo de ser e agir, são nesse sistema rapidamente recolocadas na ordem do Mesmo. Aquilo que, no sistema de pensamento dominante, é Outro como diferença irredutível, como alteridade que não pode ser totalmente conhecida, é tornada Outro do dominante como não-ser, não podendo ser ou existir. No sistema de pensamento dominante no Ocidente, o Outro é ser ou existe na medida de sua identidade com o Mesmo. A diferença, aquele que recusa ser identificada como o Mesmo, é forçada a fazê-lo, ou é aniquilada, silenciada.

Há uma razão para isto. Se a história do pensamento pudesse permanecer como lócus de continuidades ininterruptas, se pudesse forjar infinitamente conexões que nenhuma análise poderia desfazer sem abstração, se pudesse tecer, por volta de tudo o que os homens dizem e fazem, uma síntese obscura que antecipa para ele, prepara-o, e lhe conduz infinitamente para o seu futuro, lhe forneceria um abrigo privilegiado para a soberania da consciência. A história contínua é o correlativo indispensável da função fundadora do sujeito: a garantia de que tudo o que lhe escapou pode ser restaurado para ele; a certeza de que o tempo não vai dispersar nada sem restaurá-lo em uma unidade reconstituída; a promessa de que um dia o sujeito - na forma da consciência histórica - será mais uma vez capaz de se apropriar, trazer de volta sob seu domínio, todas aquelas coisas que são mantidas a uma distância por diferença, e encontrar nelas o que poderia ser chamado de sua morada. Fazer da análise histórica o discurso do contínuo e fazer da consciência humana o sujeito original de todo o desenvolvimento 
histórico e toda ação são os dois lados do mesmo sistema de pensamento. Neste sistema, o tempo é concebido em termos de totalização e as revoluções nunca são mais do que momentos de consciência (FOUCAULT, 1972, pp. 11-12, tradução nossa).

Foucault escava aqui o sistema de pensamento dominante ainda em nossos dias, que tem no sujeito a origem da história, do pensamento, do Homem. O Homem na episteme moderna está, segundo Foucault, sendo retirado de seu lugar de fundamento do saber. A história passa cada vez mais a ser entendida como produzida também por acasos e acidentes, por limiares e diferenças, por incomensurabilidade, e menos pelo Homem como fundador, embora ainda vejamos os discursos sobre o Homem dominarem nossos dias. As ações que buscam alinhar Homem e Verdade são dissecadas pelo genealogista como apenas uma forma de se pensar as relações entre subjetividade e verdade, onde a produção mesma da verdade só acontece em consonância à produção de sujeitos dessa verdade, que são sujeitados a ela no mesmo momento de sua dominância. Para Foucault, sujeitos são produzidos por discursos de verdade sobre esses sujeitos, e verdades são produzidas em consonância com a produção de sujeitos. Não há um sujeito sem história, mas não há uma univocidade da história do sujeito. Essa univocidade, ou a compreensão e prática da história como unilinear, Foucault mostra, é um certo legado cultural específico, um sistema de pensamento que está ligado a práticas dominantes em uma sociedade. Ele trouxe à tona o sistema de pensamento dominante que faz com que a história seja contada a partir de sujeitos fundantes, e a base epistemológica que reproduz esse sistema como atracada na função do discurso unívoco sobre a história, sobre a vida. A função fundadora do sujeito é uma produção histórica, como discurso. O sujeito é agente da história, podemos dizer, mas sempre dentro de circunstâncias dadas. Mas já disseram isso de forma mais elaborada:

Os homens fazem a sua própria história, mas não a fazem segundo a sua livre vontade, em circunstâncias escolhidas por eles próprios, mas nas circunstâncias imediatamente encontradas, dadas e transmitidas (MARX \& ENGELS, 1982, p. 417). 
Foucault leva a historicidade inaugurada por $\operatorname{Marx}^{2}$ a um novo patamar, e com isso nos mostrou como o legado da história contínua e única é particular a uma cultura dominante metafísica Ocidental, cristã e, como tal, não pode suportar suas próprias reivindicações de universalidade, mesmo dentro dessas tradições. A história única tem como força motriz de sua reprodução a ação voltada para a totalização, o chegar a um destino mais completo, mais verdadeiro, através do acúmulo da verdade do Ser. A história única e contínua é a prática dos sujeitos que se maximizam, que buscam de certo modo uma perfeição de suas práticas, com a garantia de que se saírem do rumo, a continuidade mesma da história estaria garantida na essência do Ser no mundo. A genealogia mostra como essa é apenas uma das muitas práticas do ser que se criaram, dos modos de produção de subjetividade, de coletividade e da história. E que esse modo de produção de subjetividade têm suas produções e seus limites, onde se encontra o Outro, e se apóia na produção de Outros para se autoproduzir. Edward Said (2003), por exemplo, relacionando o percurso de Foucault ao colonialismo, mostrou como o Oriente foi criado como um Outro do Ocidente, onde o que se diz do Oriente mostra mais sobre o próprio Ocidente com seus discursos e práticas coloniais, do que ao Oriente propriamente que é apenas um espaço imaginado do colonizador, reunindo as culturas mais e territórios mais diversos entre si, num grande Outro que ao mesmo tempo criava e justificava a dominação europeia.

Contra o modo dominante de se entender o Ser como essência metafísica e as práticas sociais como unilineares e em progressão ou evolução históricas, a genealogia joga luz sobre o que é esquecido, apagado, reescrito, silenciado, aniquilado dos Outros, pela história dominante. Nesse sentido, a genealogia é também a prática da desestabilização da dominância dos sistemas de pensamento, ela procura mostrar como, ao procurar as origens, tudo o que encontramos são cópias de cópias, como afirmou Friedrich Nietzsche. Foucault (1977, p. 146, tradução nossa) recupera a prática de Nietzsche e insiste:

A genealogia não se parece com a evolução de uma espécie e não mapeia o destino de um povo. Ao contrário, seguir o curso complexo da descendência é manter os acontecimentos que passam em sua devida

\footnotetext{
${ }^{2}$ Embora haja em Marx também uma leitura da história como contínua, que levaria necessariamente do capitalismo ao socialismo e ao comunismo, há leituras de outro Marx, histórico, onde o que o Homem se torna é específico às suas relações com outros e com a natureza.
} 
dispersão; é identificar os acidentes, os desvios minuciosos - ou, inversamente, as inversões completas - os erros, as falsas avaliações e os cálculos errôneos que dão origem àquelas coisas que continuam a existir e têm valor para nós; é descobrir que a verdade ou o ser não estão na raiz do que sabemos e do que somos, mas da exterioridade dos acidentes.

A genealogia de Foucault estava interessada em articular as impressões da história sobre o corpo, como os eventos tomam forma por sua associação com o corpo, como o Eu nunca é uma unidade e está sempre em um estado de "jogo de dominações" (FOUCAULT, 1977, p. 148) dinâmico. Procura mapear o terreno do jogo de dominações no corpo, não para fornecer uma palavra final sobre poder e dominação, mas muito pelo contrário, para permitir uma análise ponderada e crítica da problemática da sujeição e dos “modos de subjetivação” (FOUCAULT, 1994, p. 697) - o termo usado por Foucault para processos de produção de sujeitos através de práticas de si e de governo dos outros. Para Foucault, então, um sistema de efeitos diferenciais de dominação é formador do corpo, efeitos que se deslocam com a história. Foucault não fornece resolução a formas de dominação e opressão - porque a compreensão que ele consegue chegar é apenas uma entre outras abordagens possíveis, apenas uma genealogia entre outras possíveis. Sua genealogia está mais interessada em relacionar-se com os emaranhados de discursos e práticas em seus vínculos com outros discursos e práticas por meio de relações de poder, a materialidade dos corpos e acontecimentos como relações, como processos mais do que como autocontidos e opacos. Distancia-se, assim, dos modos dominantes de discursos científicos, políticos, sociais e históricos no presente que investem na busca de verdades, enquanto ao mesmo tempo aparece como a incursão na presença da multiplicidade nos discursos que reivindicam a unidade. Não como uma tarefa para o seu próprio bem, mas como uma tarefa necessária, se partirmos da compreensão do mundo atual como profundamente globalizado, ocidentalizando-se no sistema de pensamento que usa continuamente a história linear e contínua como sua forma de produção da verdade, de modos de subjetivação e dos caminhos pelo quais relações de poder são naturalizadas e capazes de funcionar.

A genealogia não era, para Foucault, a atividade mais perfeita em que ele poderia se engajar como pesquisador. Tornou-se necessária para dar sentido aos discursos que ele viu precisando ser articulados, discursos dominantes que apareceram em sua arqueologia 
cuja impermanência, abertura estratégica para manobras e heterogeneidade em relação a si provaram que nenhuma história contínua e unilinear pode captar o minucioso funcionamento do poder através dos discursos, pois os discursos são sempre uma marca de contestação e luta pela diferença.

Esse empreendimento é muito importante, dado que em nosso mundo, o conhecimento especializado - da tradição positivista, e esse claramente não é um espaço incontestável - é o legitimador das relações de poder que dominam nosso presente. Usamos aqui "nosso" em solidariedade ao globo, visto que hoje não existe um único espaço no mundo que não seja afetado por formas de conhecimento especializado espelhadas em suposições positivistas sobre o real como incontestável. Edward Said (1983, p. 2) escreve que “o reino cultural e sua expertise estão institucionalmente divorciados de suas conexões reais com o poder”. Uma abordagem genealógica estaria preocupada precisamente com as conexões de poder e conhecimento, como os mundos vividos os vivenciam. Sua necessidade em nosso presente é derivada da ausência dessa abordagem do conhecimento que o constrói como uma tradução direta de poder para o discurso, afirmando que a linguagem e o conhecimento são um subproduto secundário do poder, ou então entende o poder como um efeito direto de linguagem e conhecimento. Ambos os relatos, se falham a partir de uma perspectiva genealógica, não o fazem porque não equivalem poder a conhecimento ou porque deixam de fornecer relatos “complexos” ou holísticos de suas relações. Para Foucault, o que importa são os interstícios, a abertura adequada das relações de poder e conhecimento, e não a origem de um sobre o outro ou a impossibilidade de todas as suas relações serem contadas. Nada é estável, não há fundamentos para que nenhum tipo de conhecimento seja fixado no tempo, nem pontos de referência, apenas alteridade. Foucault encontrou, entre seus vários estudos de genealogias, ligando subjetividade, poder e verdade, sempre a alteridade dos discursos subalternos como o duplo necessário dos unitários e dominantes. Nenhum discurso é puro, unitário, mesmo aqueles - e possivelmente especialmente aqueles - que comandam dominâncias sociais autorizadas. Chatterji (2009, p. 22) escreve:

Formações subalternas, como lutas pela autonomia, como intervenções em regimes dominantes de verdade e relações sociais de injustiça, desafiam taxonomias existentes. Eles produzem altercações na cultura e na política nos interstícios da afirmação da privação-asserção, em 
simultaneidade que perturba nossa compreensão da história como linear e da resistência como espetacular.

A tarefa do genealogista é encontrar a subalternidade nos discursos e práticas mais dominantes, não para levantar o terreno da dominação e limpá-la de modo que a subalternidade seja reconhecível em si mesma (uma tarefa impossível), mas para melhor entender a dominação em sua multiplicidade de formações, sempre nos escapando onde quer que possamos localizá-la, para outro domínio. É suspender as construções de dominação e seus binários, rejeitar o mapeamento total e final da dominação e da resistência, abandonar toda vontade de verdade universal e de pureza do pensamento e das ações; é contra esses quadros que o genealogista funcionará. Precisamente onde a dominação procura tornar um Outro localizável, conhecível e se estende mesmo na resistência que procura transformá-la, ainda ler a alteridade onde a dominação busca a identidade. A alteridade que pode ser enunciada por nós (genealogistas, se eu puder) irá sempre interpor o Ser como Outro para si mesmo também, fará o Ser cada vez mais presente porque mais cheio de diferença que se baseia tanto na resistência quanto nas acomodações dentro de si-Mesmo.

Nessa busca por encontrar a alteridade mesmo nas dominações mais fortes, é impossível ao genealogista encontrar apenas um efeito unívoco em qualquer representação. Uma representação de um Outro num filme documentário será sempre múltipla e contraditória, em última instância incomensurável como é um Outro. O genealogista não faz afirmações sobre efeitos de filmes como unívocos. Entende que todo filme, ou toda produção cultural mais amplamente, carrega sempre a possibilidade de ser Outro do que é, conforme vive e é feito circular em contingências diferentes.

A genealogia de Foucault o leva a afirmar em seu livro Vigiar e Punir que a prisão funciona como um aparato de conhecimento (FOUCAULT, 1995, tradução nossa). Com isso, ele quer dizer que a prisão é um lugar onde todo um corpo de conhecimento sobre o indivíduo e seus potenciais, como perigo para a sociedade ou como um Outro possivelmente corrigível para o Mesmo, é produzido. A prisão agiu como uma força de individualização, de criação do indivíduo (alienado) como aquele de onde o conhecimento e a moralidade emanam. O livro mostra como o conhecimento dos indivíduos, a produção de conhecimento sobre a subjetividade como essência fundamental dos sujeitos, caminhava de mãos dadas com práticas de controle e transformação do comportamento dos indivíduos. Processos de disciplina, ou a efetivação 
de um poder disciplinar, eram ao mesmo tempo a observação e registro de saber sobre indivíduos, através da vigilância constante, da produção constante de saber sobre o Outro, quanto a radicalização de um processo de voyeurismo sobre o Outro com vias à produção de conhecimento que sujeitava esse mesmo Outro a essa produção, que decidia quem era delinquente, quem era corrigível ou quem não. Quem era o Outro que não tinha mais condições de viver dentro da verdade da sociedade, do Mesmo aceitável. Claramente, a individualização do saber sobre o Outro, escondia contingências históricas de formação desse mesmo Outro que era estudado como um Ser desconectado de uma vida social numa cela.

A formação de saberes sobre Outros é maior e mais prolixa, mais legitimada por discursos da ciência e das leis, quanto mais esse Outro é parte de grupos oprimidos ou subalternizados. Como objeto do saber é que muitos Outros foram criados, em relação ao dominante. O dominante, geralmente não-nomeado, é quem estuda Outros. Esses Outros, o delinquente das prisões, o anormal das clínicas, e outros povos discursados como selvagens, primitivos, assim foram categorizados devido a formações de saberes institucionais a regular a vida desses Outros, visando torná-los dóceis e produtivos para o capital, o Estado-nação, e para servir ao dominante. As construções, os "regimes de representação” (HALL, 1997), articulam tendências de significado de imagens, textos, produções culturais.

Significado 'flutua'. Não pode ser definitivamente fixado. Contudo, buscar 'fixar' é o trabalho de uma prática representacional, que intervém nos muitos significados potenciais de uma imagem na tentativa de privilegiar um (HALL, 1997, p. 228, tradução nossa).

Os significados da representação de Outros não podem ser definitivamente fixados. Mas há sempre processos, práticas de tentativa de fixação. Entre esses, processos que Foucault chama de normalização - a conjunção de conhecimento especializado, práticas institucionais e modos de subjetivação- promovem o indivíduo como a esfera de causa e ao mesmo tempo de solução do crime. O indivíduo (re)criado como sendo a origem de si mesmo e da história. O social e o político desaparecem como objetos do discurso a partir do horizonte do crime por esse processo de individualização. Vigiar e conhecer o Outro, justificar sua alteridade como fundadora de sua condição, era ao mesmo tempo invisibilizar o mundo que o criou: sociedade, cultura, política deixam, por 
via desse processo, de existir como definidores de indivíduos. Dentro da prisão, em constante observação, o preso teria direito somente a fazer o que lhe fosse pedido, a ser questionado, deveria responder, mas não teria ele mesmo direito à voz. Ele pode falar apenas quando interpelado, em situação que não é de sua escolha. Para responder a essas formas de dominação, o genealogista recorre à produção de contra-memória, que questiona a produção de conhecimento em seu trabalho como consolidação da verdade: “A contra-memória intervém nos discursos dominantes da 'verdade', liberando espaço para os saberes subalternos” (CHATTERJI, 2009, p. 16).

Para forjar a contra-memória, precisamos de práticas diferentes das dominantes. Produzir contra-memória é uma prática de relação contínua com o dominante apenas na medida em que busca forjar novas experiências de memória, não-unitárias. Precisa ser uma prática contínua, pois é na prática que ela vive, não em ideias. A contra-memória requer uma abordagem desconstrutiva (derrideana), questionando as funções da memória e incluindo a reconstrução da memória dominante. Não é contra-verdade ou contrahistória. É uma intervenção em Verdade e História no modo como são discursadas e praticadas pelo sistema de pensamento dominante.

Ao considerar a representação do Outro em documentários, uma abordagem genealógica não aceita como bastante o estabelecimento de verdades sobre Outros, especialmente se esses Outros estão inseridos em dominâncias que tentam fixar os seus significados ligados a um papel inferior numa hierarquia. Para a genealogia, o que se diz sobre Outros é apenas uma parte - muito importante - mas sempre apenas uma parte do que se produz de representações e com elas, de possibilidades do Outro ser ou não ouvido, ser ou não efetivo em afirmar a si mesmo, ser ou não capaz de minimamente afetar sua própria vida. Linguagem, incluindo a linguagem audiovisual, é apenas um lado da história quando falamos em representações do Outro.

Tanto na arqueologia como na genealogia, a linguagem é viva, não é apenas um efeito da história e das instituições sociais, é também produtiva delas, até mesmo enredada com elas em um grau inextricável. A linguagem é não-representativa. Para Foucault, é uma relação, ligando, por exemplo, o criminoso no sistema penal a um sistema de objetivação, a constituição do criminoso como um duplo objeto/sujeito. Constitui o sujeito criado como criminoso como o objeto de conhecimento que conhecemos como indivíduo e suas disposições subjetivas para a criminalidade. A linguagem da criminalidade não pode deixar de ser um local de contestação, pois a linguagem é. A construção do crime, então, através da linguagem, necessita de um campo 
de objetividade em movimento, não estático. Embora em uma decisão por um juiz ou em um testemunho técnico-científico, médico ou psicológico, o indivíduo é, para aquele momento decisivo, considerado uma criatura estática, uma espécie de desviante. Este campo opera através do controle individual, através da normalização, o que acontece através de

Um modo duplo; o da divisão binária e da marca (louco/são; perigoso/inofensivo; normal/anormal); e aquele de atribuição coercitiva, de distribuição diferencial (quem ele é; onde ele deve estar; como ele deve ser caracterizado; como ele deve ser reconhecido; como uma vigilância constante deve ser exercida sobre ele de uma maneira individual, etc.) (FOUCAULT, 1995, tradução nossa).

O que foi preparado com a individualização da sociedade, operando através da prisão? Podemos ver isso como mais um momento da gestão da violência? Qual a forma que esse gerenciamento toma? De acordo com Foucault, essa gestão toma forma justamente quando a burguesia cresce como classe, quando há vontade de tornar a sociedade produtiva. Isso envolve também uma nova maneira de administrar o tempo, para torná-lo útil, para levar ao progresso baseado na gênese dos indivíduos, ambos produzidos através de sua sistemática vigilância, gerenciamento, controle. O que conhecemos como indivíduo ou sujeito é inseparável dos processos de individuação por meio dos aparatos institucionais e da linguagem. Os indivíduos têm que ser localizáveis no espaço e no tempo, suas forças dirigidas em relação aos outros, com uma vigilância contínua quanto aos resultados obtidos a partir do arranjo de forças, uma vigilância que com o Panopticon também será auto-imposta, introduzindo o poder disciplinar que está espalhado por todo o corpo social ocidental, nos centros militares, escolas, fábricas, desde o século XVII, também ligados à conduta individual: "Também se vê a disseminação de procedimentos disciplinares, não na forma de instituições fechadas, mas como centros de observação disseminados por toda a sociedade. Grupos religiosos [cristãos] e organizações de caridade há muito tempo desempenhavam esse papel de 'disciplinar' a população” (FOUCAULT, 1995).

Disciplina, escreve Foucault, “é um tipo de poder, uma modalidade para o seu exercício, compreendendo todo um conjunto de instrumentos, técnicas, procedimentos, níveis de aplicação, metas; é uma 'física' ou uma 'anatomia' do poder, uma tecnologia” (FOUCAULT, 1995). É aquilo que se investe na normalização dos indivíduos, seu apego 
aos modos de conhecimento que os constrangem ou os liberam, mas sempre dentro de formas de poder que buscam torná-los conhecíveis entre si e para si mesmos, e localizáveis e administráveis por instituições. As disciplinas ocupam os interstícios, a microfísica de nossas formas jurídicas, são fundamentais para nossa compreensão de nós mesmos como tendo liberdades jurídicas. "O Iluminismo, que descobriu as liberdades, também descobriu as disciplinas” (FOUCAULT, 1995). Pode-se dizer que as liberdades foram produzidas através de mecanismos disciplinares, e estes, por sua vez, vieram através de uma suposição da liberdade como um problema. Pode-se dizer também que estes se tornam uma sociedade empenhada na produção e conversão de todos em trabalhador. Aqueles considerados inaptos para o trabalho, foram estudados - produzidos como delinquentes, equacionados com os crimes que cometeram e com um corpo de conhecimento que correspondia a eles, chamado criminologia. Disciplina exige, como uma forma de poder que é, que um corpo de conhecimento acompanhe suas ações de normalização.

A prisão, aquela região mais sombria no aparato da justiça, é o lugar onde o poder de punir, que não se atreve a se manifestar abertamente, organiza silenciosamente um campo de objetividade no qual a punição poderá funcionar abertamente como tratamento e a sentença ser inscrita entre os discursos do conhecimento. É compreensível que a justiça tenha adotado tão facilmente uma prisão que não seja fruto de seus próprios pensamentos. A justiça certamente devia à prisão esse reconhecimento (FOUCAULT, 1995).

O reconhecimento de que a história tem seus fluxos, suas mudanças, que só avançam no tempo, mas que no momento em que tentamos localizar um evento específico, encontramos sempre numerosas rupturas, é a tendência perspectivista nietzschiana da genealogia. Quebrando a história, mostra que espaços como a prisão são uma multiplicidade de efeitos, sem centro para segurá-la, pendurada no capitalismo de um lado, no sistema judicial de outro, e a burguesia de um terceiro lado, como da prisão surgiram também coisas que pareciam novas, mas apenas com relação à própria prisão. $\mathrm{O}$ exame e a normalização dos sujeitos, construídos como indivíduos por meio desses mecanismos, são parte integrante da prisão, do capitalismo, do sistema judicial e da formação da dominação de classe. Não há, então, apenas um sistema normalizante ou 
individualizante, a criação de sujeitos é dessa forma múltipla e contraditória. No entanto, a normalização dos sujeitos que acontece na prisão não é o simples efeito desses três outros lados, nem o lugar onde, a priori, essas instituições sociais se reproduzem. Em vez disso, a normalização vem de muitos lados.

Trata-se também da formação do conhecimento e de sua reprodução que, por uma perspectiva genealógica, é fragmentada, dispersa. É por isso que a prisão não é a “descendência” dos "próprios pensamentos” da justiça. A prisão é aquela instituição nascida das múltiplas montagens de histórias que vêm de múltiplos lugares, incognoscíveis para nós em última instância, das quais só podemos ver um reflexo de partes do nosso presente e suas muitas formas de dominação. Contar a história de sujeitos é atentar para a multiplicidade incomensurável destes, ao mesmo tempo em que é reconhecer que há a necessidade de sondar quais são os discursos e formações históricas importantes na produção do que se pode ver e falar de sujeitos, ou o que os próprios sujeitos veem e falam. É por isso que, mesmo quando Foucault afirma - como ele não poderia ter feito de outra forma - que a prisão é parte do sistema judiciário, ele escreve sua história, genealogicamente, como vindo de muitos lugares que não são apenas esse sistema. Na tentativa de encontrar objetos em uma história, Foucault sempre encontra outros objetos, todos criados em sistemas, pois todo sistema de pensamento cria (ao menos parcialmente, ao menos no nível da linguagem) seus objetos.

Ele também encontra continuidades. Desde o século XIX, as críticas à reforma das prisões permaneceram praticamente as mesmas até nossos dias: que a prisão não diminui a taxa de criminalidade; que a detenção causa reincidência; que a prisão não pode deixar de produzir delinquentes; que joga a família do preso para a miséria, etc. Estas são várias críticas ainda feitas. Em todas estas, a criação do Outro como delinquente, como um modo de subjetividade diretamente acessível pela lei, que se torna responsável por ele. Os reformadores penitenciários, ao tentarem questionar a legitimidade do sistema prisional devido à sua produção de delinquência, estavam ao mesmo tempo produzindo delinquentes. Seu discurso, ao tentar explicar o funcionamento da prisão, promoveu de fato um modo de conhecimento que veio a legitimar, mas mais do que isso, criar uma realidade a ser conhecida como tal, um domínio de verdade e objetos com o delinquente construído como o Outro a ser estudado e regulado. Como causa e efeito da prisão (embora o Outro como delinquente só tenha vindo à tona depois de estabelecida a prisão). O delinquente é o sujeito que sempre escapa ao controle total e à normalização pelo 
sistema carcerário. Foucault pergunta: “O suposto fracasso não é parte do funcionamento da prisão?” (FOUCAULT, 1995).

Pois foi justamente a discussão em torno do fracasso da prisão que fazia parte da produção de delinquência, do delinquente como um "sujeito patologizado", que então retroativamente se insinuava a necessidade da prisão, para sua normalização. Isso ilustra como a genealogia também é perigosa, pois se tomarmos qualquer formação de sujeito como um produto de certas tecnologias de poder, precisamos repensar todas as nossas instituições atuais e a maneira como elas nos normalizam. O perigo da genealogia está em gerar nossa necessidade de repensar, possivelmente, todas as nossas instituições ocidentais, nossas subjetividades dominantes disponíveis, nossas práticas de produção de conhecimento em sua capacidade de nos normalizar.

A resistência à normalização exige uma abordagem genealógica da história, porque simplesmente existe pouca informação disponível que reconheça as falhas fundamentais em qualquer tentativa de envolver a normalização, a fim de promover mudanças sociais. A genealogia reconhece a impossibilidade da pureza no discurso tanto quanto na ação social e nas instituições. Não procura fornecer um refúgio seguro ou um ponto de vista livre de dominação de onde ver melhor a dominação, de fora. Não existe tal coisa. Na verdade, muito pelo contrário. Foucault mostra como a dominação está ainda mais presente precisamente nas tentativas de resistir a ela em seus próprios termos. Todo discurso de resistência reproduz o que critica de uma maneira ou de outra. A genealogia torna-se então uma disposição estratégica de críticas baseadas em rupturas seletivas de continuidades e descontinuidades históricas. O processo de seleção, pode-se apenas imaginar, tem a ver com a atenção que está sendo dada às contingências atuais do que está sob escrutínio, mais a capacidade do genealogista de trazer o jogo de dominações para uma relação com o presente. Na genealogia, só há perspectiva, nenhuma tem como propósito um mapeamento total do campo das relações de poder e saber, pois não existe tal univocidade das relações de poder e saber: como relações do mundo que são, estão vivas, sempre em movimento, escapando a qualquer mapeamento ou registro totalizador.

Para tanto, a tarefa de fornecer arqueologias do conhecimento se torna indispensável, pois é somente através delas, com suas transições e contradições e multiplicidades internas, que o genealogista pode trazer o presente para o jogo entre as contingências. Este jogo, o genealogista só pode esperar, será aquele que permitirá aos outros repensarem seus sistemas de pensamento como sistemas. A genealogia reivindica, 
assim, uma relação com a desconstrução, com a ruptura da cientificação de tudo o que impede a justiça no presente como responsabilidade ética da produção de conhecimento. Não para que esta prática nos coloque dentro do verdadeiro ou do justo, mas por causa de uma prática do mundo e do eu que deseja dissipar o poder das formas de normalização, tornando elas pelo menos mais suportáveis, se não esperançosamente irreconhecíveis em práticas futuras de libertação.

A genealogia como prática implica dúvidas fundamentais sobre as possibilidades de libertação, no entanto, com um correspondente hiperativismo de interrupções do que é construído como verdade, arte, linguagem, cultura, ciência, nação e história. Ela opera através de uma violência nietzschiana, porque as palavras não dizem sobre ações voluntariamente, precisam ser levadas a isso, e o conhecimento nunca é transparente, sempre um jogo de luz e sombra. No sentido foucaultiano, a intervenção nos saberes dominantes condiciona diferentes arranjos de dominação, nunca a liberdade total. Vamos de dominâncias em dominâncias, e a questão é saber quais podem melhorar a vida de quem nos importa. O que podemos conseguir, esperançosamente, é um rearranjo do jogo de dominações e das violências que os seguem, visando melhoras para nós ou para Outros de nós. Brincando com dominações, o genealogista nunca se liberta delas, nunca é capaz de colocar a questão final, na verdade duvida de sua existência, e tenta se entender como sempre já falando de dentro, nunca sem, o jogo das dominações. Dentro dos domínios, a genealogia exige rigor em testemunhar a diferença e a particularidade. Exige que, ao encontrar dominações, que se percorra seus caminhos e seus efeitos possíveis na vida das pessoas no presente. Isso requer um compromisso de viver com discernimento, por isso é também uma “prática do eu” (FOUCAULT, 2005). Requer um tipo específico de prática do eu, que se inclui no domínio das relações (dominantes) a serem testemunhadas.

Tal prática não inclui a possibilidade de conhecimento pleno, na verdade, torna a parcialidade de acesso às realidades aquilo que se necessita testemunhar. Testemunhar não é feito em um vácuo, então o genealogista precisa dos Outros, fala apenas sobre os Outros em suas resistências e dominações presentes, de modo a fazer da genealogia uma luta pela justiça - e não a verdade da justiça. É somente através dos Outros e através do testemunho que pelo menos alguma habilidade para discernir a injustiça pode surgir. Esse testemunho pode incluir o que faz as pessoas viverem, lutarem, resistirem, lamentarem, festejarem, celebrarem e morrerem. Isso nos força a entender as histórias de produção em socialidade, pensamento e legados - como necessárias em aliança com outras pessoas. 
A intervenção genealógica é intersticial, age entre o texto e o mundo. Isso está longe de ser uma prática comum nos ambientes acadêmicos tradicionais. O texto foi, nesses ambientes, designado como aquele que, por si só, representa uma leitura do mundo, divorciado do mundo.

\begin{abstract}
Isso pode ser considerado, penso eu, o triunfo da ética do profissionalismo. Mas não é por acaso que o surgimento de tão estreita definição de uma filosofia de pura textualidade e não-interferência crítica coincidiu com a ascendência do reaganismo, ou mesmo com uma nova guerra fria, aumento do militarismo e gastos com defesa e uma volta massiva à direita em assuntos que tocam a economia, os serviços sociais e o trabalho organizado. Tendo desistido inteiramente do mundo pelas aporias e paradoxos impensáveis de um texto, a crítica contemporânea recuou de seu eleitorado, os cidadãos da sociedade moderna, que foram deixados às mãos das forças "livres” de mercado, das corporações multinacionais, das manipulações. dos apetites do consumidor (SAID, 1983, p. 4, tradução nossa).
\end{abstract}

O genealogista não discute textos por si mesmos. Ou práticas sociais. A genealogia, tanto quanto a desconstrução derrideana, é uma prática de justiça. Ou então corre o risco de se tornar apenas mais uma crítica aos textos por si mesmos, seja pela construção de carreira acadêmica, seja pela manutenção do status quo. Como prática de justiça, não deseja o fechamento, a permanência das relações entre os textos, o eu, o Outro e o mundo. Ela precisa refletir continuamente sobre seus efeitos à medida que eles circulam, à medida que o mundo se movimenta, à medida que o eu é continuamente repensado em sua luta pela justiça com os seus aliados. A genealogia procura entender as cumplicidades das formas de dominação entre si, suas estratégias de dispersão e enredamento entre si, as maneiras pelas quais elas podem se misturar umas com as outras e também com formas de resistência.

Na produção de documentários, uma reflexão genealógica nos impele a sempre reavaliar os efeitos das escolhas de modos de produção e circulação na vida dos Outros sujeitos filmados e também na de Outros que sejam afetados. Não existe um vácuo de efeitos, ou apenas efeitos circunscritos e totalmente cognoscíveis: os efeitos de produções culturais como filmes se produzem continuamente na sua circulação e fora de qualquer 
controle total possível. Isso clama por uma atentividade contínua para essa (re)produção de cultura e que informa a ética e política do documentário.

A micropolítica do poder, analisada por Foucault em Vigiar e Punir, as formas pelas quais o poder emana e se aprofunda nos aspectos mais minuciosos da vida social na sociedade disciplinar, mostra como a tarefa do genealogista é a de um cartógrafo de relações mutáveis, onde apenas relações e não coisas em si existem. Nada evapora, extingue-se, tudo em si é outra coisa, dominação sempre marcada por resistências a ela e vice-versa. A dominação atua não apenas pela supressão e repressão, mas pela produção da diferença, disseminada pelo corpo social, sem necessidade de centro. Os objetos produzidos pelas disciplinas são elementos de uma estratégia, e é a tarefa da genealogia e o livro Vigiar e Punir é um exemplo disso - mapear o jogo, as estratégias possíveis, o que foi experimentado ou - deixando para a interpretação do leitor - poderia ter sido tentado. A genealogia também mostra o que está presente, mesmo quando parece que a história mudou completamente. Para a genealogia, a história está sempre mudando, mas nunca completamente, pois isso seria uma reivindicação da verdade acima da própria história. A genealogia é a tarefa de fazer com que o conhecimento da história se coloque em função do presente como uma luta por justiça sem verdade final.

\section{Como utilizamos a genealogia nesta pesquisa}

O filme documentário, enquanto objeto de pesquisa e de discursos tanto acadêmicos quanto de realizadores, é alvo desde seu início, de discursos concernentes à razão de sua existência, ao que ele pode ou não pode fazer, a suas fronteiras ou pontes com outros gêneros do cinema e das artes. Essa pesquisa não faz uma análise de todos os discursos sobre o documentário, em primeiro lugar, porque isso é praticamente impossível de realizar por apenas uma pessoa, em um momento onde todos os dias são lançadas novas pesquisas e discursos ancorados no objeto filme documentário. Em segundo lugar, porque uma genealogia é sempre um recorte, ela necessita do recorte, de um modo parecido ao de qualquer ciência, para poder ser feita.

Mas sua diferença para o discurso científico é que a genealogia assume de antemão que seu trabalho não visa um objeto - como o filme documentário social, ou o filme documentário político etc. - e sim sobre as condições de formação de relações que produzem um filme documentário e os discursos que lhe dão vida e sustentação. $O$ discurso sobre o filme documentário nasce junto com o próprio, como parte de suas 
relações, e vem de outros lugares para além do próprio como objeto criado pelo discurso. O discurso realista sobre o cinema, por exemplo, nunca foi o único a circular sobre o documentário. O discurso sobre os usos do documentário, como pedagógico ou como arte ou como político, também se retroalimentam na história do uso do termo documentário para designar filmes. Além do mais os discursos sobre o filme documentário vêm também de outros lugares, outros objetos e relações com a cultura, artes, e com as contingências de subjetividades, instituições e legados do pensamento envolvidos.

Nosso propósito com essa pesquisa é buscar uma compreensão dos modos pelos quais o documentário tem sido produzido e discursado enquanto um meio da representação do Outro. Em particular, estamos interessados em saber como se dá a utilização das vozes de Outros nos filmes documentários, e da possibilidade dos filmes serem produzidos com vistas a fazer ressoar a voz de Outros a fim de se tornarem os filmes instrumentos de intervenção social para a melhoria da vida dos Outros sujeitos filmados.

Como realizador de documentários e como pesquisador do tema, realizo a genealogia dos usos das vozes de Outros nos filmes a fim de buscar abrir conversas sobre a ética, a política e a relevância social do documentário. A pesquisa, portanto, é interessada em si mesma. Ela parte do lugar do realizador e pesquisador que quer entender caminhos para a produção de documentários onde as vozes de Outros são o eixo de produção de efeitos que visam reverberar para além dos filmes.

O que esperamos compreender com isso é se há lugar, tanto na prática quanto no pensamento sobre o filme documentário, para um aprofundamento sobre maneiras de produzir filmes onde as vozes de Outros visam mudanças sociais em que os filmes participam como aliados de propósitos de Outros sujeitos filmados. Ao fazer essa colocação, fazemos um convite à pesquisa sobre o tema e à realidade que encontramos ao realizar a nossa: a ausência quase total de pesquisas que versam sobre vozes de Outros como parte integrante de filmes documentários integrando as implicações disso para mudanças sociais. A maior parte das pesquisas que encontramos, além dos discursos de realizadores e de pensadores dos documentários em artigos, livros, palestras, entrevistas etc., versa sobre a impossibilidade de representar o Outro, ou sobre a irrelevância, ou inconsequência, de filmes que buscam representar vozes de Outros visando fins de mudanças sociais, legais, culturais ou políticas. O que é notável, já que nunca se produziu tantos filmes documentários como na última década, e grande parte desses filmes visa justamente se colocar como ressonâncias das vozes de Outros, é certo que para diversos 
fins, mas muitos filmes se baseiam nas vozes de Outros para indicar, mesmo que poeticamente ou de modo não didático muitas vezes, problemas que afligem Outros em sua possibilidade de uma vida melhor.

Esta não é uma pesquisa que visa provar que se pode dar voz ao Outro. Também não é uma pesquisa que parte da impossibilidade da representação da voz do Outro. Ela vai buscar, naquilo que fazem, e naquilo que dizem que fazem através de seus realizadores, os filmes documentários, meios para compreender como se constroem discursos e práticas sobre o filme documentário em sua relação com as vozes de Outros. É nos interstícios entre práticas, discursos e efeitos, em sua relação com o mundo vivido dos Outros, que podemos pensar o filme documentário enquanto uma rede de relações que ele sempre é. Pensar como o mundo sempre atravessa um filme, e se assim é, pensar e trabalhar o filme documentário como agente vivo nesse mundo, é tanto uma perspectiva quanto uma afirmação ética e política do documentário.

Em nossa parcialidade, sabemos que o que estamos a propor não é nem inovação nem uma volta ao passado. Estamos no meio da história do documentário, sempre. É nesse meio, numa história do presente, que fazemos nossa escrita de nós mesmos, que é realizada essa pesquisa, uma documentação de onde estamos como cultura do documentário, como estamos com nossas relações entre documentário e os Outros que buscamos como documentaristas ouvir. O que podemos com o documentário e com os Outros sujeitos filmados depende também de como temos definido para nós documentaristas e para Outros o nosso trabalho. É possível ouvir as vozes de Outros na voz do documentário? Mais do que respostas prontas, entender as redes que formam respostas dominantes e inibem Outras respostas, subalternas, é nossa tarefa numa genealogia.

Para isso, no capítulo 1 começamos pela própria história do documentário em sua relação com Outros. Ao sondar as múltiplas articulações e modos de representação de Outros no documentário desde os primeiros filmes, passando pelo advento do som sincrônico e os novos modos de representar Outros no Cinema Direto e no Cinema Verdade, em que o Outro ainda era representado dominantemente por cineastas que olhavam de fora para dentro esses grupos, para produções mais recentes nas quais o Outro passa a se auto-representar. Na história que contamos aqui do documentário, o Outro é, a princípio, representado por um olhar de fora, não fala em sua voz (até porque não havia meios para isso); depois passamos para um momento no qual a voz do Outro é um dos principais ingredientes do documentário, mas ainda predomina a representação 
distanciada de cineastas que observam ou produzem representações mescladas entre suas vozes e a de Outros. Posteriormente, enfim, chegamos ao momento em que o Outro (no sentido da alteridade a discursos dominantes) se auto-representa, e com isso vem a confrontar representações, discursos e práticas que se abatem sobre grupos oprimidos. Nesse trajeto, notamos a valorização das produções que visam não tipificar o Outro, não produzir generalizações ou fechamentos, mas que junto trazem também um distanciamento em relação a representações dominantes sobre o Outro, e concebem o documentário como instrumento de mudanças sociais. Posicionamos o documentário numa rede de relações que são fundamentalmente políticas, no que concerne ao modo como ele se insere sempre num mundo, onde não há escolha sobre reproduzir ou não as dominações, onde a questão da inserção do documentário em relações de poder e saber que o atravessam sempre está presente.

No capítulo 2, nos detemos na questão da "voz do documentário", conceito desenvolvido pelo pesquisador e professor Bill Nichols, para aprofundar o debate sobre as maneiras pelas quais o filme documentário se insere no mundo, quais efeitos ele vem a produzir, bem como com que intenções e motivações é produzido. Começamos pela discussão da $\mathrm{Voz}$ de Deus como um legado do documentário que tanto teve dominância quanto produziu reações adversas e produções que buscam dele se desligar. A univocidade e as representações fechadas sobre o Outro, que marcaram parte da história do documentário, são seguidas por uma repulsa criativa que produz novos modos do documentário, aliado a novas técnicas que se tornaram possíveis, como o som direto captado no momento da filmagem, em que a voz de Outros passou a figurar e, muitas vezes, a ser considerada bastante para os filmes. No entanto, muitas vezes as vozes de Outros foram também usadas para fechamentos unívocos - ao menos na intenção - o que ocasionou nova ruptura. Documentaristas começaram a produzir filmes em que a monofonia era evitada, em que os fechamentos se tornaram repreensíveis.

O documentário passou a ser concebido como representação e não como a realidade em si mesma. A partir disso, caminhou-se para a cristalização de uma dominância dos discursos sobre o documentário como não sendo um representação direta da realidade, e sim na fronteira entre filme e arte. Isso foi feito tanto por meio de discursos reativos à Voz de Deus e a outros legados da representação do Outro que foram colocados como problemáticos, quanto por meio de filmes que passaram a produzir distanciamento de qualquer ligação com uma tentativa de influenciar ações no mundo, ou o filme ser, ele mesmo, visto como uma ação. Em nossa pesquisa, partimos da visão do 
filme documentário como discurso. Desse modo, o filme documentário nunca deixa de (re)produzir políticas, sejam culturais, artísticas, de linguagem, de subjetividade, de saber e poder, seja diretamente, seja involuntariamente. Nesse recorte que fazemos dos discursos e práticas do documentário, analisamos a voz do documentário como um conceito útil se for alargado para incluir os modos de recepção e de produção de efeitos de filmes na vida de Outros, passando a entender a voz do documentário como processo vivo, sempre em (re)construção a partir das relações entre cineastas, sujeitos filmados e públicos.

No capítulo 3, tratamos das relações estabelecidas num filme documentário entre cineastas e Outros sujeitos filmados, tanto para a produção quanto para a tentativa de criação de efeitos desejados pelos filmes que, embora nunca garantidos, podem ser trabalhados em aliança. Discutimos a aliança entre cineastas e Outros sujeitos filmados como importante em filmes nos quais o intuito seja promover melhorias de vida para esses Outros; assim, apresentamos ideias do que seria um Aliado, baseados em aprendizados que tivemos ao escutar movimentos negros, indígenas, feministas e outros. Discutimos como os Outros que são representados pedem cada vez mais que filmes lhes forneça condições de representatividade, lugar de fala, e outros conceitos importantes para os movimentos sociais na atualidade como o movimento negro, o indígena, o LGBT, o feminismo. Aprofundamos nossas considerações sobre as (im)possibilidades do Outro ter sua voz representada na voz do documentário tanto em termos dos discursos dominantes enfrentados por filmes, quanto na intencionalidade colocada em filmes para que produzam efeitos, novamente, embora não haja garantias de representação. A fim de desenvolver nossas hipóteses apresentamos alguns estudos de caso de filmes em que vozes de Outros oprimidos são representadas, não para alcançar modelos, mas para pensar caminhos sobre o que fazer e o que não fazer, deixando aos leitores as opções abertas. Discutimos, ainda, o que seria uma voz libertadora, aquela que pode representar a voz do Outro na voz do documentário e se faz ressoar por ser afirmativa de si mesma e de Outros, por mais que haja diferenças, e como, no entanto, a nenhuma voz está garantida ser escutada ou produzir efeitos pretendidos. Ao final, argumentamos que a ética do documentário está mudando, que o documentarista que até então evitava falar pelo Outro pode passar a falar com o Outro novamente, em aliança, de seu lugar de fala específico, numa recomposição do documentário como intervenção no mundo visando mudanças. 


\section{CAPÍTULO 1}

\section{Documentário e seus Outros}

\subsection{O cinema nasce do encontro com Outros}

O documentário pode ser entendido como tendo tido a mesma origem ao cinema, começando nos primeiros registros por Thomas Edison, passando pelas primeiras projeções dos irmãos Lumière, chegando ao amadurecimento com filmes como Nanook (1922), de Robert Flaherty, pelos grupos soviéticos e também pelos britânicos nos anos 1920, esses últimos em torno de John Grierson. Já em 1914, Edward Curtis cunhou o termo “documentário” para o registro em parte espontâneo e em parte dramatizado feito para a câmera pelos povos nativos Kwakwaka'wakw, no seu filme $\mathrm{Na}$ Terra dos Caçadores de Cabeças. Nesse momento temos a origem do exercício documental e dizendo isso, não estamos aqui postulando a verdadeira origem do documentário, pois assim como seu status como gênero do cinema pode ser questionado, também podemos questionar seu momento de nascimento. Documentário define um objeto que, assim como muitos outros, carece de unanimidade quanto às suas origens e limites. Enquanto alguns autores, como Bill Nichols, afirmam que de algum modo “Todo filme é um documentário” (2001), outros, como Fernão Ramos, consideram o documentário um gênero do cinema (2013). O que grande parte, senão a maioria dos estudiosos, concorda é que filmes documentais têm relação com o mundo vivido por sujeitos específicos e localizáveis no tempo e espaço. Como toda prática cultural, o documentário - e aqui o artigo “o” utilizado já invoca uma noção de singularidade histórica unívoca, que pretendemos alargar - é problematizado em sua existência singular, especificidade, limites e margens. Quando se recupera a origem ou história do documentário, ela sempre é contada a partir do ponto de vista específico de quem narra. No Brasil, Amir Labaki nos conta que os primeiros documentários silenciosos podem ser datados antes dos anos 1900 (LABAKI, 2006, p. 18).

Desde o início de sua história, o documentário é contestado em sua unidade ou mesmo como gênero específico. Frances Flaherty, esposa de Robert Flaherty considerado por muitos como o primeiro documentarista - colocava em questão se o que seu marido fazia era dizer algo sobre o mundo, ao filmar povos tidos como "primitivos" 
nos lugares mais distantes. Ela defendia que ele estava apenas interessado em "art for art's sake”, arte pela arte, e que nada lhe interessava dizer sobre o mundo. Frances Flaherty dizia que Robert Flaherty não carregava nada pré-concebido sobre a realidade, e que, ao contrário do trabalho que ele realizava, por definição o documentário seria um modo de trabalhar apenas com o pré-concebido. A questão que foi levantada por muitos sobre o trabalho de Flaherty, como, por exemplo, por seu amigo e ao mesmo tempo rival ideológico John Grierson, era: será que não há algo pré-concebido em trabalhar com culturas e temas parecidos: culturas exóticas? Será que uma pré-concepção já não existe ao se escolher quem filmar, como filmar, onde filmar e como contar uma história?

Quando Robert Flaherty criava Nanook, escolheu atores para formar uma família nuclear Inuit, um povo aborígene da América do Norte. A vida comunitária dos povos com os quais filmou ${ }^{3}$ está quase ausente nos seus filmes. Ao filmar povos diferentes dos seus, Flaherty os recriava para ficarem mais parecidos com sua visão de mundo eurocêntrica ocidental (embora acreditemos que muito provavelmente o fazia de modo inconsciente, pois ele acreditava estar realizando filmes sob o ponto de vista dos sujeitos filmados). Flaherty filmava o que podemos chamar de "Outro cultural”, mas o recriava ao fazê-lo. Por “Outro cultural” nos referimos tanto ao fato de que cineasta e sujeitos filmados fazem parte de grupos culturais distintos, com suas diferenças de território, língua, crenças, modos de vida e hábitos, quanto reconhecemos que, a respeito de “Outros culturais” que não se enquadram como ocidentais, há sempre discursos que préconcebem o que se diz sobre Outros, como são imaginados. O termo “discurso” usado por Michel Foucault é central para nossa análise das relações entre linguagem, práticas sociais, relações de poder e de como linguagens, incluindo a linguagem audiovisual do cinema, é sempre formada ela mesma por legados do pensamento, e ao mesmo tempo práticas sociais e instituições. Para Foucault, um discurso é sempre ligado à "episteme”, isto é, às estruturas do saber, do tempo histórico e do contexto sociocultural e político dentro do qual emerge. O termo também é empregado não como conceito final, mas estrategicamente, conforme as camadas de complexidade de saberes, linguagens e instituições a que Foucault se refere, não se tornando possível dessa maneira uma definição final e totalizadora do termo.

Os discursos também influenciam em como a cultura dominante ocidental se relaciona com Outros. Utilizarei neste trabalho a noção de dominância articulada por

\footnotetext{
${ }^{3}$ Robert Flaherty, como veremos adiante, praticava um modo de produção do documentário que trazia os sujeitos filmados a co-produzir seus filmes.
} 
Raymond Williams no livro Marxism and Literature (1987, p. 113): "Uma maneira de expressar a distinção necessária entre os sentidos práticos e abstratos é falar do 'hegemônico' ao invés de 'hegemonia' e do 'dominante' ao invés da simples ‘dominação'”. Com isso, Williams consegue falar dos processos de opressão, resistência e produção cultural, social e política sem criar instâncias monolíticas como Cultura, por exemplo, para a qual podemos indicar se estamos falando de uma forma de cultura dominante ou de formas de resistência ou de diferença a uma cultura dominante. O conceito de dominância implica tanto que há relações de poder, saber e institucionais que operam para reproduzir formas de opressão, quanto pode significar um campo do nãopensado, não-refletido, não-dito que, por isso mesmo, passa e se faz valer. Utilizo como derivantes desse conceito de dominância as palavras dominante e dominantemente.

Toda relação com Outros é carregada, e quanto mais oprimidos ou subalternos ${ }^{4}$ os grupos tornados Outros, mais difícil é escapar da reprodução de relações desiguais quando o cineasta entra em posição de filmar esses Outros-sujeitos filmados. Por isso é que em parte Grierson tem razão quando diz que o que Flaherty faz não é desprovido de pré-concepções. Sendo uma relação entre desiguais no nível do poder colonial, a produção de filmes por ocidentais sobre povos chamados nativos, indígenas ou aborígenes nunca se dá numa igualdade plena de poderes, ou num vácuo de poder. Ao mesmo tempo, podemos retornar a mesma crítica a Grierson mesmo, pois na nos argumentos dele contra Flaherty também existe um dogmatismo que é o de somente filmar o atual e o familiar, como se apenas a identificação com sujeitos filmados pudesse autorizar uma representação mais fiel a suas realidades ou pudesse garantir um maior valor documental. Porém, mesmo quando o Outro, como sujeito filmado, é supostamente familiar ao cineasta - a exemplo de como o documentarista John Grierson pensava que produzia filmes sobre pessoas familiares a ele por habitarem próximo - não se pode clamar igualdade de poderes sem com isso subestimar as relações desiguais que sempre podem existir entre quem filma e quem é filmado. Para Grierson, diferentemente de Flaherty, fazer documentários não seria apenas fazer arte, seria também a possibilidade

\footnotetext{
${ }^{4}$ De acordo com Gayatri Chakravorty Spivak, “(...) subalterno não é apenas uma palavra elegante para "oprimidos", para [o] Outro, para alguém que não está recebendo um pedaço do bolo (...) Em termos pós-coloniais, tudo o que tem acesso limitado ou o imperialismo cultural é subalterno - um espaço de diferença. Agora, quem diria que é apenas o oprimido? A classe trabalhadora é oprimida. Não é subalterno (...) Muitas pessoas querem alegar subalternidade. Eles são os menos interessantes e os mais perigosos. Quero dizer, apenas por ser uma minoria discriminada no campus da universidade; eles não precisam da palavra "subalterno" (...) Eles devem ver o que são os mecanismos da discriminação. Eles estão dentro do discurso hegemônico, querendo um pedaço do bolo, e não sendo permitido, então deixe-os falar, use o discurso hegemônico. Eles não devem se chamar subalternos” (DE KOCK, 1992).
} 
de impulsionar melhorias no mundo vivido, ou seja, para ele, o valor do documentário estava em ser uma interferência no mundo.

Ao mesmo tempo em que Flaherty construía um Outro para seus filmes, ele o fazia buscando com os próprios sujeitos filmados seu roteiro e seu modo de representar esse Outro. Sabemos que ele instituiu um método próprio que consistia em filmar e assistir logo em seguida o que havia filmado junto com os personagens. Quando filmava Nanook durante o dia, reunia seus atores à noite para assistirem ao material gravado verem e juntos comentarem juntos sobre os aspectos que estivessem funcionando, o que precisaria ser melhorado, e desse exercício partiam dali ideias de sequências para o filme. Nanook pode ser considerado, em parte, uma co-criação entre o cineasta e os sujeitos filmados, embora a decisão final sobre o que seria filmado e como seria montado o filme fosse tenha sido de Flaherty. Com essa escolha por de trazer seus atores - que na vida real viviam de forma muito parecida, porém, nunca exatamente como as histórias filmadas - para decidir sobre os rumos do filme, Flaherty deu início a um legado dentro do documentário que foi levado adiante por outros cineastas:, que é o de envolver os sujeitos filmados num processo de colaboração, o que em certos casos se desenvolve estende até mesmo para a co-direção de filmes.

Esse legado iniciado por Flaherty foi citado pelos diretores do filme Two Laws, ou Duas Leis (Direção Alessandro Cavadini e Carolyn Strachan, 1982). Two Laws é um filme inteiramente feito no modo de co-criação e co-direção, em que os diretores australianos deixam à cabo do povo aborígene todas as escolhas sobre o que filmar, como filmar e como montar o filme final. Os diretores apenas operam a câmera e o gravador de som, transferindo as decisões do sobre o filme para os sujeitos filmados. Podemos ver claramente em Two Laws que há escolhas de feitas sobre os modos de apresentação das questões dos aborígenes, bem como na escolha dos temas que foram tratados, com especial atenção para a questão de terra e territorialidade, centrais nas vidas dos nativos.

Os aborígenes usaram o filme como modo de luta, encenando e até teatralizando tudo que lhes tinha acontecido e que escolheram mostrar num na narrativa de um filme, inclusive visando seus efeitos práticos em termos de leis e políticas. Sem dúvida, o fizeram porque julgaram que o filme poderia ser um instrumento de sua luta por melhor qualidade de vida e por direitos sobre terras. Há necessariamente da por parte dos diretores uma disposição muito grande de em se deixar guiar pelas vontades dos aborígenes, colocando estas talvez até acima da sua própria visão sobre o que seria o filme. Dessa forma, tal projeto inovou ao levar ainda mais a sério certos caminhos que já 
tinham sido traçados anteriormente por Robert Flaherty. Em Two Laws, vemos essas tendências de para novas formas do fazer documental, pois não se tratava mais apenas de realizar um filme para mostrar a um público curioso sobre povos aborígenes, mas de fazê-lo também com intenções claras do que se quer alcançar com o filme de em termos de efeitos sociopolíticos que se quer alcançar com o filme. No caso dos aborígenes, deixaram estava clara a intencionalidade em lutar por suas terras ancestrais.

Podemos dizer, então, que a força do filme Two Laws reside está em justamente em ter sido co-criado e co-dirigido, pois com isso os aborígenes conseguem conseguiram levar a uma discussão sobre o que está na raiz do impedimento impede seu acesso a suas terras e deixar essa questão dar forma ao filme. Há a lei do branco, que os impede de ter suas terras ancestrais, mas também há a lei dos aborígenes ${ }^{5}$, que os liga fundamentalmente e espiritualmente à terra. Sua terra não é apenas física, é também o espaço da cultura e do espiritual, a terra necessária para a própria continuidade da cultura. Eles conseguem articular no filme tanto na temática quanto no desenho espacial imagético da narrativa, e decidem inclusive pelo título da obra. Imprimem, assim, a si mesmos e à sua disputa central em um filme feito para eles próprios, mas também para que outros vejam e entendam suas reivindicações e a maneira pela qual identificam-se com elas. Chegar a esse tipo de desprendimento em relação ao seu controle sobre o filme, no caso dos cineastas brancos, quanto ao seu controle sobre o filme, é muito difícil. Geralmente os cineastas se preocupam em realizar filmes para certas audiências - brancas ou dominantes - que têm expectativas quanto a linguagens, conteúdos, técnicas e formas. Em Two Laws, o controle é evidentemente cedido aos aborígenes para que façam o que precisam fazer com o filme.

Com Two Laws, podemos ver como um filme pode ser um instrumento de lutas políticas e culturais de uma população, como pode ser apropriado mesmo que essa população não seja ela mesma quem tecnicamente opera a câmera ou grava o som, mas ainda assim tem meios de dirigir sua obra. Isso diz muito sobre como há padrões dominantes de produção de filmes, que não se deixam influenciar pelos grupos e sujeitos filmados que exibem. Sabemos que, na história do documentário ou do filme etnográfico, há uma quantidade muito grande de filmes que foram feitos sobre o que estamos pleiteando como Outro cultural, um Outro que é construído muitas vezes como

\footnotetext{
${ }^{5}$ A lei do branco, na concepção aborígene no filme, são as leis do Estado. A lei dos aborígenes compreende sua história e mitologia sobre a criação e o que essa mitologia lhes concede como habitantes de terras ancestrais que são para eles espirituais.
} 
homogêneo, vivendo ou pensando igual, sem diferenças internas, sem contradições. O cineasta ou antropólogo se coloca, geralmente, como aquele que pode falar sobre o esse Outro, até mais do que esse o próprio Outro ${ }^{6}$. Atualmente vemos um movimento nesse sentido e já temos filmes que se descolam dessa tradição, filmes que não buscam fechamentos sobre o Outro, mas essa tradição de falar pelo Outro foi forte o bastante para continuar ecoando até mesmo nas nossas formas de recepção de filmes que buscam fazer diferente. Assim é que, mesmo obras que se recusam a falar pelo Outro, que inclusive se recusam a representar seres humanos ao máximo que podem, como faz o filme Sweetgrass (Direção Lucien Castaing-Taylor e Ilisa Barbash, 2009) ao filmar quase que exclusivamente ovelhas e não os seus pastores humanos, não conseguem imprimir uma imagem desse Outro humano sem ajudar a estereotipá-lo: os efeitos de filmes que buscam neutralizar a representação de Outros muitas vezes são contrários às intenções de seus realizadores. Todas as formas de representação de humanos correm o risco perene de ajudar a estereotipar os sujeitos filmados. Pois já desde o século XVI, antes dos filmes, os missionários cristãos, e depois os antropólogos, entre muitos outros grupos de cultura dominante, já haviam deixado seu legado de representação sobre Outros na cultura ocidental.

Nunca conhecemos totalmente esse Outro cultural, mas sempre temos alguns enquadramentos e julgamentos prévios que acabam por moldá-lo em alguns pré-conceitos que carregamos. Devemos nos perguntar: quem é esse "nós” que reconhece/desconhece um Outro? Quem em “nós” ouve, vê, sente? Por que o faz de certas maneiras e não de outras? Quais são os legados de pensamento e sentimento, quais os paradigmas de ser e existir que nos formam para que tenhamos certos efeitos de um certo Outro em nós, e não de outros/Outros? Assim é com cineastas, assim é com quem assiste como público. O Outro não é muitas vezes o Mesmo. O Mesmo é um conceito criado dentro da filosofia crítica, que mostrou que a filosofia dominante no ocidente é metafísica, definida por Jacques Derrida (1978) como a “metafísica da presença”. Nela, há sempre uma divisão do mundo em dualismos, criando uma hierarquia entre o que é considerado Verdadeiro contra o Falso, entre outras construções que colocam na origem dos acontecimentos a Verdade, o Ser, a Interioridade, e apenas como consequência destes é que haveria

\footnotetext{
${ }^{6}$ A Antropologia é o campo que justamente por ter nascido sobre a produção de conhecimento sobre Outros povos, nações, etc. Acabou também por ser a disciplina que veio a questionar sua própria prática - a de falar pelo Outro incitada também em grande parte pelos povos estudados que vieram a questionar os estudos antropológicos feitos sobre eles. Até mesmo antropólogos que antes estavam habituados a fazer etnografias sobre outros povos vieram a repensar suas práticas a partir do final dos anos 1970. Ver como exemplo o livro Nova Luz Sobre a Antropologia, de Clifford Geertz.
} 
possibilidade de diferenças, porém diferenças que sempre partem do Mesmo (Verdade, Ser, Interioridade) e a ele retornam como origem.

O empreendimento de retornar 'estrategicamente', 'idealmente', a uma origem ou a uma prioridade considerada simples, intacta, normal, pura, padrão, auto-idêntica, para então pensar em termos de derivação, complicação, deterioração, acidente, etc. Todos os metafísicos, de Platão a Rousseau, Descartes a Husserl, procederam dessa maneira, concebendo o bem antes do mal, o positivo diante do negativo, o puro diante do impuro, o simples diante do complexo, o essencial antes do acidental, o imitado antes da imitação, etc. E isso não é apenas um gesto metafísico entre outros, é a exigência metafísica, aquilo que tem sido o mais constante, mais profundo e mais potente (DERRIDA, 1988, p. 236, tradução nossa).

Nesse sistema de pensamento, o Outro só existe e só pode ser afirmado como o Mesmo, portanto como identidade com o dominante. Não há pois, espaço para a diferença incomensurável, intraduzível ao Mesmo. O que a crítica de Derrida à metafísica coloca é que o Outro só pode ser Outro na medida em que não é igual ao Mesmo, ao Universal, ao Homem, a todo discurso de "presença” que torna todas a diferença familiar. Há sempre a possibilidade do Outro já ser outro dele mesmo no momento de ser filmado ou interpretado. Mas há sempre os legados de representação pairando sobre todos, que tentam fixar o Outro em significados estabelecidos dentro da metafísica do Mesmo.

O Outro de Flaherty não deixa de ser Outro por conta do cineasta considerar esse Outro um Mesmo, familiar, pela via de um certo humanismo ou romantismo que pode ser lido nos seus filmes. Muito pelo contrário. Flaherty produz seus filmes dentro de um contexto de público ocidental, dos anos 1920, que considerava a alteridade dominantemente apenas sob o prisma do Humano-Mesmo, aquele que em todo lugar seria igual em essência. Essa essência é (re)produzida por Flaherty pelos modos como humanos em determinado lugar se relacionam com o meio natural para ter condições básicas de sobrevivência como comer, vestir, dormir. Justamente por essa redução do humano a um denominador pretensamente comum, ou seja, a sobrevivência na natureza, em que o humano seria Humano-universal, a diferença já vem nesse caso empacotada, pré-concebida dentro dos moldes dominantes de entender o humano no Ocidente. A história de um povo que é julgada relevante de ser contada tem esse julgamento realizado 
por alguém que não faz parte da comunidade. E como alguém que não faz parte, traz seus próprios interesses e visões de mundo. Sabe-se que Flaherty cresceu numa comunidade de pescadores. Isso pode ajudar a explicar em parte suas escolhas de temas e lugares que filmou. Talvez por sua própria história, sendo ele parte de uma comunidade não-moderna (numa visão dominante sobre o moderno), acabou ele por mostrar que culturas que parecem muito diferentes ou estranhas não o são, ou pelo menos não são um Outro enquanto apenas diferente.

O amigo e um dos maiores críticos de Flaherty, o escocês John Grierson, numa trajetória em certos pontos oposta à dele, buscou o familiar, o mais perto de casa, o “drama at the doorstep”, (o drama em casa, familiar), como ele dizia. Talvez uma de suas maiores contribuições tenha sido, além do fomento à produção de documentários britânicos, a guinada para a representação do que ele considerava próximo: a vida de trabalhadores retratados com dignidade. Ao invés de representar o exótico, como fez Flaherty, ou o heroico, como faziam os soviéticos que filmavam propagandas para a nascente União Soviética, Grierson se voltou para o trabalhador cotidiano. Ele disse, em uma reação crítica direta a Flaherty:

Temos acreditado persistentemente que o primeiro e último lugar para encontrar o drama da realidade é naquilo que homens de hoje estão fazendo e pensando e planejando e lutando. Temos de fato encontrado nosso campo de observação e os padrões brutos de nosso trabalho no choque de forças dentro de nossa própria comunidade metropolitana (GRIERSON, 1946, p. 16, tradução nossa).

Tanto Flaherty quanto Grierson se consideravam em campos opostos, porém por razões distintas: enquanto Flaherty dizia que fazia apenas "arte”, Grierson lhe cobrava uma intencionalidade clara de engajamento social ou de mensagem sobre o mundo para os filmes. Contudo, os dois tinham um campo em comum para discordar: Flaherty fazia arte, porém uma arte que retirava o que tinha a mostrar apenas do que um dia foi real para os sujeitos filmados ou para o cineasta e sua visão sobre o que se convém chamar de real; já Grierson considerava mais real aquilo que se pode chamar de contemporaneidade, particularmente dos trabalhadores das cidades da Grã-Bretanha, junto a pessoas supostamente mais familiares a ele. Mas há algo que, enfim, os dois têm em comum é a crença de que filmes representam a chamada "realidade" do Outro e que isso pode ser feito por um cineasta 
tomando para si as decisões sobre a representação. É esse ponto que os aglutina enquanto operadores de um mesmo discurso sobre a representação do Outro. Eles divergem no modo de produzir documentários sobre a "realidade" do Outro, mas não questionam as (im)possibilidades de representação de realidades por filmes. A discussão entre eles era mais sobre onde e quem representar, e o que isso faz - arte pelo seu próprio valor, no caso de Flaherty, ou mudança social, no caso de Grierson -, do que um questionamento, que pouco havia na época, sobre o que fazem os cineastas ao representar uma “realidade”. Flaherty admitia abertamente que "em alguns aspectos seus filmes são tanto sobre ele mesmo - seus prazeres, seus preconceitos, suas convicções - quanto sobre as pessoas que ele filmava” (ELLIS \& MCLANE, 2005, p. 22, tradução nossa). Flaherty via beleza nos modos de vida de culturas diversas, mesmo porque as filmava levando-as a dizer algo para além delas mesmas, pois dramatizava situações criadas por ele.

Grierson, por outro lado, tinha uma intenção de função educativa para os documentários, queria mudar o mundo o mais diretamente possível por meio deles. Acreditava que a função do filme como um "tratamento criativo da atualidade”, como veio a definir o documentário (GRIERSON, 1933, pp. 7-9), era encontrar modos de intervir no meio social ao buscar mostrar novas compreensões do supostamente familiar. Flaherty e Grierson então, disputavam entre si, ou melhor dizendo, somente poderiam ter disputado tanto entre si sobre os significados e os valores atribuídos aos seus filmes por estarem num mesmo plano quanto ao que compreendiam estar representando em seus filmes. Para os dois, tratava-se de levar às telas a realidade como a viam. Mesmo que a construção da realidade no filme fosse diferente para cada um, os filmes carregavam em si versões diferentes de realidade, sendo para Flaherty apenas “arte” para ser apreciada sem qualquer compromisso ou intencionalidade elaborada para ter efeitos no mundo vivido, enquanto Grierson dizia: "Vejo o cinema como um púlpito, e o uso como um propagandista” (ELLIS \& MCLANE, 2005, p. 71). Havia, tanto em Flaherty quanto em Grierson, a noção pré-concebida de que o cinema é uma linguagem universal e até mesmo necessariamente benéfica. Os perigos da representação de Outros (mesmo aqueles Outros supostamente familiares aos cineastas) naquelas décadas de 1920 e 1930 não eram questões centrais nas discussões sobre o documentário ou sobre o cinema em geral.

Flaherty foi precursor de uma tendência emocional, até potencialmente romântica, de representação do Outro no documentário. Já Grierson inaugurou a tendência racionalargumentativa, baseada no discurso da evidência e na linguagem didática. Grierson trabalhava com o tratamento de temas onde poderia haver consenso, apelava ao senso 
comum - um caminho que não era o dos documentaristas norte-americanos dos anos 1930, por exemplo, que tinham posições mais minoritárias, consideradas ideologicamente de esquerda, e por isso mesmo sofreram com a falta de patrocínios para seus filmes. Grierson era propriamente um cientista social, despreocupado e desinteressado dos “problemas pessoais do homem” individual, assim como da estética dos filmes. Para ele, o conteúdo é a mensagem ao povo, ao coletivo, muito semelhante ao que vinham fazendo os soviéticos como Dziga Vertov, Sergei Eisenstein e outros. Já muitos documentaristas norte-americanos e canadenses tinham em geral uma preocupação maior com a estética, assim como uma visão de mundo mais baseada em personagens específicos, trilhando um caminho aberto por Flaherty.

Podemos dizer que Flaherty representou para a história do documentário o advento da representação do Outro como uma busca pela beleza. Grierson, por sua vez, acreditava que a busca pela beleza atrapalhava as mensagens e priorizava o conteúdo como mensagem racional quase instrumental. A história do documentário é repleta de filmes utilitários que ensinam a realizar ações técnicas, relatam sobre um novo desenvolvimento da medicina, ensinam sobre as ciências. Outros filmes foram doutrinadores, como aqueles feitos por americanos, britânicos e canadenses em apoio ao esforço de seus países na Segunda Guerra Mundial ${ }^{7}$. A utilidade de filmes para gerar efeitos sociais em direção a motivações, que vão desde a melhoria de serviços públicos ao ensino e até mesmo para a guerra, mostra a diversidade de instrumentalizações a que documentários serviram.

É indiscutível que documentários são usados para intervir na sociedade, na cultura, na política e - podemos até mesmo dizer - nos rumos da história. Porém, isso não é uma verdade sobre todos os documentários. Muitos estão mais para retratos, documentos sobre o mundo, alguns tendendo mais para representações sobre a Beleza (Flaherty) presente no mundo, do que para o filme como uma intervenção social nesse mundo por meio de um conteúdo racional (Grierson). Outros são uma mistura das duas tendências. E outros, ainda, como alguns documentários experimentais, são difíceis de classificar, até como documentários.

\footnotetext{
${ }^{7}$ Dentre estes, destacamos a série de sete filmes documentários intitulados Why We Fight, encomendados pelo governo dos Estados Unidos durante a Segunda Guerra Mundial para justificar aos soldados dos EUA o envolvimento de seus países na guerra. Mais tarde, eles também foram exibidos ao público dos EUA para persuadi-lo a apoiar o envolvimento dos EUA na guerra. Em 2005 foi lançado um filme documentário homônimo, dessa vez crítico ao militarismo e guerras dos EUA dos últimos 50 anos. Ver Why We Fight (Direção Eugene Jarecki, 2015).
} 


\subsection{O Outro e seus duplos}

Nem tudo se resume a dualismos, oposições binárias. No Ocidente, temos uma tendência a enxergar tudo em dualismos. Como disse Michel Foucault (1977, p. 230), há uma “dualidade fundamental da consciência Ocidental”, a qual organiza o mundo em torno de objetos e sujeitos, sempre em contradições ou oposições binárias. Esse legado do pensamento dominante Ocidental vem de muito tempo, da metafísica enquanto sistema de pensamento que há milênios se reproduz, mas também dessa mesma metafísica enquanto modos de vida e do viver, da organização de instituições e do saber Ocidentais. Desse modo, não é de surpreender que possamos facilmente cair na tentação - ou mais precisamente, no legado - dualista e colocar Flaherty e Grierson como ocupantes de tendências completamente opostas, com filmes de Flaherty e seus seguidores ocupando o espectro do Sujeito/Emoção/Arte de um lado, e aqueles produzidos com a ajuda de Grierson e suas equipes como sendo pelo Objeto/Razão/Ciência. Claro, Grierson compunha ele mesmo um discurso sobre o documentário que promove esse entendimento dualista, no qual para além dessa divisão, estaria também uma diferença de valor, colocando o "seu” lado, o do Objeto/Razão/Ciência em superioridade moral/estética em relação ao outro lado.

Como formula Jacques Derrida, na história dos dualismos no Ocidente, não se trata apenas de separar o mundo em dois lados: há sempre um lado colocado como moralmente superior ao outro:

Uma oposição de conceitos metafísicos (fala/escrita, presença/ausência, etc.) nunca é o face a face de dois termos, mas uma hierarquia e uma ordem de subordinação. A desconstrução não pode limitar-se ou proceder imediatamente à neutralização; deve, por meio de um duplo gesto, uma dupla ciência, uma dupla escrita, praticar uma reviravolta da oposição clássica e um deslocamento geral do sistema. É somente nessa condição que a desconstrução proverá os meios para intervir no campo de oposições que critica (DERRIDA, 1982, p. 195, tradução nossa). 
A colocação dos dualismos é uma só com as estruturas de injustiça, por isso podemos definir a desconstrução derridiana como uma prática da justiça. Os dualismos e as formas dualistas de representação se reproduzem por e são reproduzidas por formas de opressão, violência, injustiça. Esse modo de representação do Outro na forma do dualismo é evidente nas relações do Ocidente com povos indígenas pelo mundo afora, em que esses povos são caracterizados geralmente no negativo dentro da oposição: "sem Estado”, “sem escrita”, sempre em oposição a um Ser (europeu, branco, masculino no mais das vezes etc.) que é o Sujeito contra o qual o Outro é construído (TORGOVNICK, 1990). Dualismos também foram fundamentais nas relações com povos da Ásia chamados Orientais (SAID, 2003), onde todo um conjunto de ideias sobre o Oriente, tido como homogêneo, se fundou na construção de um conjunto oposto sobre o Ocidente esse seria racional, livre, por exemplo, enquanto o Oriente seria irracional e despótico. Para Edward Said, o Orientalismo não era apenas um conjunto de teorias sobre o Oriente e o sujeito Oriental, os quais esse mesmo discurso produziu. O Orientalismo foi possível justamente porque haviam relações opressoras, coloniais, entre povos que se diziam Ocidentais, ou passaram a se chamar assim, ao subjugar os que vieram a ser chamados de Orientais. Discurso colonial (dualista) e colonialismo andam juntos, as práticas institucionais de colonização caminham juntas às práticas de formatação de saberes e de subjetividades coloniais. O colonialismo é mais forte porque produz sujeitos coloniais tanto do colonizador quanto do colonizado.

Com povos do continente africano ou da diáspora africana os dualismos também aparecem, e Frantz Fanon (2007) mostrou como nessa construção do sujeito negro, o que sucede a ele é que a inferiorização de tudo que remeta à sua diferença racial, faz com que este busque se identificar com a ideologia e cultura dominante branca. Para Fanon, tanto a libertação institucional do poder colonial, quanto a libertação a nível subjetivo do negro como sujeito colonizado eram duas faces da mesma moeda. Há sempre uma interiorização relativa da opressão quando o poder colonial opera de forma a prejudicar quem se identifica com o Outro e a valorizar somente um dos lados do dualismo. Quando o sujeito pertence ao grupo tornado Outro, muitas vezes sua forma de resistir inclui modos de assujeitamento e negação de si, pois o valor dominante se encontra justamente em não ser Outro da cultura dominante. A libertação do colonialismo tem, portanto, um fator inegável de auto-valorização e auto-superação, em conjunto com a libertação de poderes institucionais. 
Ao falar sobre o Outro e como ele é representado, o que estamos vendo é que, pela história do Ocidente, outros povos, nações, religiões e grupos não dominantes têm dificuldade para se verem representados pelas imagens, saberes, crenças, instituições dominantes. Quando Gayatri Spivak pergunta “Pode o Subalterno Falar?” (WILLIAMS; CHRISMAN, 1994) ela se refere às formas como as tentativas de "falar a verdade" sobre alguém são tão cheias de problemáticas e de perigos tanto para os que se consideram aliados quanto para as formas mais colonialistas de representação. Quando os intelectuais pós-coloniais tentavam falar pelo sujeito colonizado, de forma muito direta reproduziam aquilo que buscavam combater: a representação do Outro por sujeitos que não estão localizados e dominados pelas mesmas estruturas de poder e saber. O que aprendemos com a filosofia contemporânea, com os estudos pós-coloniais, o feminismo entre outros legados contemporâneos do pensamento, é que a resistência sempre reproduz ao menos em parte o que ela critica. E que se isso não é prontamente identificado, o que deve importar é: há que se ter por precaução a predisposição a aceitar que nenhuma resistência é total, assim como nenhuma liberdade é final.

A teleologia, as filosofias do fim da história, são também o fim da vida, e se a vida segue, essas filosofias precisam estar erradas. A possibilidade da alteridade deve sempre permanecer aberta, e para isso ao menos ao nível do pensamento, este não pode quietar e dar por finda a questão do Outro. O pensamento, para dar conta ao menos parcialmente da heterogeneidade do corpo político e social, precisa estar sempre se fazendo Outro de si mesmo. Spivak, seguindo o legado dentre outros de Jacques Derrida, recusava qualquer ponto final sobre a questão da alteridade, pois um ponto final nessa questão seria mais um sinal e uma ação de opressão. Esse foi sua crítica ao movimento de pensadores pós-coloniais que, ao criticar o colonialismo, criaram noções do Subalterno como um sujeito unívoco e homogêneo, criando assim a impossibilidade de diferenças internas às colônias de poderem se expressar. Ao falar pelo Sujeito Colonial, mesmo com as melhores das intenções, os pensadores anticoloniais e mesmo pós-coloniais reproduziam a metafísica do Outro que combatiam no colonialismo.

Spivak aponta para os perigos de qualquer representação essencialista de um Outro (e nosso uso aqui de Outro com letra maiúscula é justamente para ressaltar e apontar que o essencialismo sempre pode ser lido no Outro). O perigo do essencialismo é tanto para um grupo, nação, cultura, ou mesmo um Estado, quanto para um sujeito individual. Porém, em todo discurso que, num primeiro momento, pode soar essencialista, como "Eu sou isso”, “Eu penso assim”, “Nós queremos assim”, não está 
dada a questão sobre o essencialismo. Esse Outro que fala afirmativamente e de modo unívoco pode precisar justamente dos efeitos do essencialismo para melhorar sua vida. "Eu quero isso" pode ter os efeitos pretendidos por quem vocaliza por exemplo, e isso muitas vezes é o que importa ali àquele sujeito em questão. A questão do essencialismo, como Spivak demonstra, não é se diz ou não a verdade. A questão que deve ser vista é se o discurso unívoco (ou pelo menos a tentativa é unívoca) melhora ou piora a vida do sujeito subalternizado. Por isso é que Spivak cunhou o termo "essencialismo estratégico" (2008), ao perceber que as colocações essencialistas têm um papel mobilizador e que muitas vezes podem ser a única opção disponível rumo a uma melhora da vida, da liberdade, do que seja que se busca. É interessante notar como toda a crítica tanto póscolonial quanto pós-moderna pode sempre ser cooptada pelos centros e sujeitos investidos de privilégio. Robert Stam e Ella Shohat (2005, pp. 404-405) mostram como

os escritores metropolitanos anunciam a "morte do autor" exatamente quando os escritores "periféricos" começam a ganhar seus prêmios Nobel. Todos esses “desinvestimentos" refletem um privilégio disponível somente àqueles já investidos de poder, porque a proclamação do fim das margens não põe fim aos mecanismos que de fato desapropriam os povos de suas culturas ou as nações de seu poder. (...)

O fato de que a identidade e a experiência sejam mediadas, narradas, construídas, apanhadas na espiral da representação e da intertextualidade não significa que a luta tenha chegado ao seu final. Diana Fuss ${ }^{8}$ distingue entre "empregar" e "ativar" o essencialismo, por um lado, e "mergulhar" ou "afundar" nele por outro. O que Spivak denomina "essencialismo estratégico" e o que [Stuart] Hall chama de "necessidade ficcional do fechamento arbitrário" são cruciais para qualquer luta multicultural que pretenda tornar possíveis comunidades de identificação, ainda que estas sejam múltiplas, descontínuas e parcialmente imaginárias.

A escritora e ativista bell hooks - que usa seu nome artístico assim mesmo, em minúsculas, para diminuir a importância de sua pessoa como autoria em relação ao conteúdo de suas obras como intervenção no mundo - reconhece a validade da crítica pós-moderna a

\footnotetext{
${ }^{8}$ Ver Diana Fuss, Essentially Speaking. Londres: Routledge, 1989, p. 20-21.
} 
metanarrativas. A colocação da problemática das metanarrativas foi feita por Jean-François Lyotard (1984). Lyotard mostrou como as metanarrativas, aquelas narrativas que se desenvolvem a partir do preceito do Sujeito Universal que tem acesso ao conhecimento de forma unívoca, pois a esse Sujeito todo conhecimento verdadeiro seria unívoco, se desenvolveram de forma paralela a instituições de poder como o Estado, a Ciência, o Partido, todos esses lidos e praticados também como unívocos e universais. Obviamente, esses Universais eram tanto mais universais quanto mais se alinhavam aos saberes dominantes (nesse contexto, brancos, masculinos, ocidentais, cristãos etc.) em jogo. Essa crítica, também feita pelos movimentos anti-coloniais e pós-coloniais, gerou uma discussão sobre ela ser inerente ao processo de pós-modernismo. Embora esse também seja um termo amplo e complexo, alguns autores como Stuart Hall (2003) entendem que houveram transformações nas práticas e saberes sobre identidades que nos permitem entender um processo pós-moderno (que não refuta totalmente o Sujeito Universal Moderno, porém reage a ele). Os movimentos negros, indígenas, feministas e outros se utilizaram da crítica pós-moderna à univocidade do Ser e do Mundo para buscar ampliar os espaços de debates, práticas, vivências e possibilidades de vida. Houve aberturas possíveis para vozes e identidades que antes estavam abafadas ou invisibilizadas pela dominância do Sujeito Moderno - o Homem Universal.

As críticas às orientações do pensamento pós-moderno não devem obscurecer as percepções que este pode oferecer que abrem nossa compreensão da experiência afro-americana. A crítica do essencialismo encorajada pelo pensamento pós-modernista é útil para os afroamericanos preocupados em reformular noções antiquadas de identidade. Há muito tempo nos impusemos, tanto de fora como de dentro, uma noção estreita de negritude. Críticas pós-modernas do essencialismo que desafiam noções de universalidade e identidade estática sobredeterminada na cultura de massa e na consciência de massa podem abrir novas possibilidades para a construção do self e a afirmação da agência (HOOKS, 1994, p. 425, tradução nossa).

Porém, hooks também aponta os perigos de análises que não consideram as lutas contra o racismo e o colonialismo, e outras formas de opressão. Pois nenhuma teoria é crítica de dominações em si, sem seus laços com comunidades de prática. A crítica pósmoderna à identidade pode ser uma abertura de possibilidades de resistência para sujeitos subalternizados e oprimidos em luta contra estruturas opressoras. 
A cultura pós-moderna com seu sujeito descentrado pode ser o espaço onde os laços são rompidos ou pode proporcionar a ocasião para novas e variadas formas de vínculo. Em certa medida, rupturas, superfícies, contextualidade e uma série de outros acontecimentos criam lacunas que abrem espaço para práticas oposicionistas que não mais exigem que os intelectuais sejam confinados a esferas estreitas e separadas, sem conexão significativa com o mundo de cada dia. Muito do envolvimento pós-moderno com a cultura emerge do anseio de fazer um trabalho intelectual que se conecta com hábitos de ser, formas de expressão artística e estética, que informam a vida cotidiana de uma população em massa, assim como escritores e acadêmicos. No terreno da cultura, pode-se participar de um diálogo crítico com os pobres sem instrução, a classe baixa negra que está pensando em estética. Pode-se falar sobre o que estamos vendo, pensando ou ouvindo; existe um espaço para troca crítica. É emocionante pensar, escrever, falar e criar arte que reflita o engajamento apaixonado com a cultura popular, porque isso pode muito bem ser "a" localização central futura da luta de resistência, um local de encontro onde acontecimentos novos e radicais podem ocorrer (HOOKS, 1994, p. 427, tradução nossa).

Uma das chaves para se contornar os modos de representação dominantes do Outro em filmes, evitando assim os legados dominantes da construção seja colonial, seja dualista, ou ainda buscar encarar de frente e com responsabilidade a parcialidade e incompletude de qualquer representação, é buscando trazer o Outro a uma maior participação ativa na produção da imagem de si. Esse legado, como já apontamos, pode ser entendido como tendo iniciado com Robert Flaherty e seu convite aos sujeitos filmados para co-criar os filmes. Mas quando a tecnologia passou a permitir ouvirmos a voz do Outro de modo sincrônico nos anos 1960, outras possibilidades de representação surgiram.

Um dos primeiros filmes a gravar a voz dos entrevistados e a dar início ao estilo de entrevistas foi Housing Problems (Direção Edgar Anstey e Arthur Elton, 1935), produzido pelo grupo em torno de Grierson. Depois de ouvir os problemas na voz de pessoas que vivem em más condições de moradia, o filme apresenta soluções, apoiado em falas de especialistas. Esse filme é um marco na história do documentário por dois motivos: busca ouvir as pessoas diretamente afetadas sobre seus problemas e busca 
encaminhar soluções. Realizado em 1935, o filme reflete o otimismo de alguns documentaristas britânicos à época, em torno do projeto iniciado por Grierson. Mas há um outro motivo para considerá-lo importante: o documentário apontava tipos de soluções para o problema da moradia apenas aquelas referentes ao aspecto técnicoarquitetônico, que se mostraram insuficientes. Housing Problems mostrou que não basta apenas ouvir o Outro - morador de casa insalubre, nesse caso -, em torno do projeto iniciado por Grierson. Esse filme vinha numa trajetória griersoniana de documentários que são sobre o Outro e seus problemas, porém numa tentativa de se manterem apolíticos, isto é, de não tomarem uma posição crítica a sistemas e culturas políticas, sociais e econômicas. Grierson não faria uma crítica ao capitalismo. Em Housing Problems, a tecnocracia é a linguagem que impera sobre o Outro. Esse Outro, na realidade, não é ele mesmo nem parte do problema, nem parte da solução. Ele é apenas um meio que aponta os problemas para que soluções técnicas ou tecnológicas possam ser encontradas. O Outro é, no legado griersoniano, fundamentalmente despotilizado. ${ }^{9}$

O legado flahertiano é também fundamentalmente despolitizado, mas de outra maneira, pois ele nem tem por meta intervir no campo social, político ou cultural. Sua intencionalidade é outra, a de realizar uma representação do Outro que seja uma poética de imagens. No entanto, esse legado também é o dos efeitos das construções de representações desses Outros. Ao criar uma imagem do “nativo” em O Homem de Aran (1934), Flaherty não se atentou para o fato de que estava criando uma mitologia sobre as pessoas da ilha de Aran. Como consequência do filme, o turismo floresceu para ver os sujeitos do filme, mesmo que estes não existissem mais na realidade, pois a ilha já não era mais habitada, e tanto as famílias quanto suas atividades foram todas encenadas para o filme. O filme How the Myth Was Made: A Study of Robert Flaherty's Man of Aran, dirigido por George Stoney, um descendente de ex-moradores da ilha de Aran, mostra como um filme pode depois ser questionado em seus efeitos por aqueles a quem busca representar. Para algumas pessoas de Aran, o filme as retrata de maneira problemática como "pobres" e eles se sentiram mal representados. O filme de Flaherty passou a ser usado como instrumento de turismo, sendo apresentado aos visitantes e trazendo receitas aos envolvidos, porém mesmo assim não conseguiu ser um fator de orgulho para eles (WINSTON, 1995, p. 219). Ao representar o Outro, sempre o fazemos de um ponto de vista. Se este não é devidamente e rigorosamente refletido pelo cineasta ao produzir,

\footnotetext{
${ }^{9}$ Brian Winston (1995, p. 49) deixa claro esse ponto e coloca que o filme Turksib, de Viktor Alexandrovitsh Turim, pode ter deixado esse legado de filme apolítico ponto do qual Grierson teria partido.
} 
inevitavelmente uma visão muito parcial se dá. Por mais que Flaherty tenha tentado conviver, ao modo de um antropólogo, com as pessoas que filmava, e buscando extrair do cotidiano delas suas histórias, ele não tinha como escapar do seu próprio olhar e parcialidades. A questão já colocada pelos estudos culturais, pós-coloniais, feministas e outros legados sobre a representação do Outro é que ela é sempre parcial. O cinema, mesmo quando é sobre um Outro olhar, pode agir para que de incomum esse Outro se torne comum ou familiar, ao menos ao nível dos discursos e imagens das formas de representação dominantes.

Formas de representação, mesmo quando aparentemente libertadoras são criações. A construção do Outro num filme será o resultado das condições de sua produção, bem como de recepção, sua “comunidade interpretativa” (FISH, 1980, p. 22). Com esse conceito, Stanley Fish nos ajuda a entender que nenhuma interpretação é imparcial, pois toda interpretação precisa de uma formação, uma socialização na interpretação. Uma interpretação só acontece quando tem seu espaço para ser. O filme Let There Be Light, de John Huston (1946), termina a série de filmes de guerra nos Estados Unidos, realizados por diversos diretores com financiamento público que exaltavam o esforço de guerra do país e aliados na Segunda Guerra Mundial. Nesse filme, pela primeira vez temos registrado em documentário o lado mais sombrio dos efeitos de guerra sobre soldados. Soldados com problemas psíquicos ficam oito semanas no hospital, e Huston registra suas atividades do dia a dia com psiquiatras em sessões individuais e coletivas. O filme mostra também como eles ficam com a fala prejudicada por conta de traumas de guerra. É interessante como o filme nos permite notar como traumas de guerra - violência e perigo extremos - mexem com a capacidade de fala dos soldados. É o primeiro filme a tratar sobre Transtorno de Estresse Pós-Traumático ${ }^{10}$, antes do termo ter sido inventado. A narração em voice over constrói um Outro unívoco e dá um tom otimista ao final. Todos estariam recuperados. Não poderíamos esperar diferente de um filme que foi feito por encomenda do exército, desse modo não havia como não terminar de modo otimista se Huston quisesse ter autorização para mostrá-lo ao público. Huston queria provocar um entendimento de que as guerras têm efeitos devastadores sobre soldados. Mas a Polícia Militar confiscou o filme logo antes dele ser exibido em um festival de documentários no Museu de Arte Moderna de Nova York. O filme foi censurado por um longo período de

\footnotetext{
${ }^{10}$ O Transtorno de Estresse Pós-Traumático tem sido colocado pela psicologia e psiquiatria como distúrbios resultantes de situações de alto estresse como guerras, acidentes, estupros, sequestros, e outras situações traumáticas, após as quais a pessoa-vítima afetada revive sensações, têm reações e pesadelos ligados a esses traumas.
} 
40 anos. Talvez porque, segundo seus censores, ele tivesse um impacto muito forte exatamente sobre o esforço de guerra. Em relação a civis, pesquisa de 2018 do Departamento de Assuntos de Veteranos dos Estados Unidos mostra que os soldados veteranos de guerras nos Estados Unidos têm o dobro de chances de cometer suicídio ${ }^{11}$, e cerca de 20 vinte morrem todos os dias dessa forma ${ }^{12}$.

Por mais que se tente, nunca se consegue transmitir a realidade cruel da guerra por meio da fotografia ou de um filme, como já nos alertou Susan Sontag no livro "Regarding the Pain of Others”, ou Sobre a Dor dos Outros (2003, p. 126). A dor do Outro é algo que em última instância não se pode transferir. A estetização do sofrimento e da opressão, o tornar o sofrimento do Outro, já oprimido pelas circunstâncias, “bonito” na fotografia ou em filmes, opera também como mais uma forma de reproduzir a opressão.

\begin{abstract}
Pensava-se, quando imagens cândidas não eram comuns, que mostrar algo que precisava ser visto, trazendo uma realidade sofrida para mais perto, compeliria os espectadores a sentir mais. Num mundo onde a fotografia está brilhantemente a serviço de manipulações consumistas, nenhum efeito de uma fotografia de uma cena dolorosa pode ser tomada como garantida. Como consequência, fotógrafos moralmente alertas e ideólogos da fotografia tem se tornado cada vez mais preocupados com as questões de exploração do sentimento (piedade, compaixão, indignação) em fotografia de guerra e em maneiras rotineiras de provocar sentimentos (SONTAG, 2003, pp.79-80, tradução nossa).
\end{abstract}

A fotografia, ou o filme, podem provocar sentimentos pelo Outro em nós, mas nunca nos fazer passar pelos sofrimentos do Outro. A representação não é capaz de nos fazer vivenciar plenamente uma experiência de outra pessoa, mesmo quando a tecnologia dos dias atuais com o possibilidade tecnológica que nos leva a passar por simulacros de realidade virtual. Pois sempre somos nós que entramos numa cena de cinema 360 graus, 3D, ou outros tipos de tecnologia. Nunca podemos ter o Outro representado de forma

\footnotetext{
${ }^{11}$ https://www.nbcnews.com/health/health-news/veterans-more-likely-civilians-die-suicide-va-study-finds-n884471.

12 https://www.realcleardefense.com/articles/2017/09/21/veterans_society_and_suicide_112346.html.
} 
transparente, numa relação de 1 para 1, quando adentramos essas realidades produzidas pela tecnologia, mesmo que o Outro esteja ali representado. Portanto não se trata nunca de uma questão apenas tecnológica.

A questão, idealmente, é não mais como representar o "outro”, mas como colaborar com o "outro”, ou melhor dito, como criticar as práticas produtoras de alteridade. (Ao fim e ao cabo, não há “outros”, mas tão somente "alterização".) O objetivo, raramente reconhecido, passa a ser garantir a efetiva participação do "outro" em todas as etapas de produção, inclusive na produção teórica (STAM; SHOHAT, 2004, p. 413).

A participação dos sujeitos filmados em documentários, como já vimos, vem desde o início da história do documentário, com Robert Flaherty. Recuperamos esse dado nesse momento para dizer que apesar dele ter trazido. Ele trouxe a participação desses sujeitos na fase de planejamento de cenas e de sequências. Porém, ainda levaria cerca de 10 anos para que a montagem e a narração de filmes entrassem no rol dos processos participativos em documentários a partir de Jean Rouch. Assim como o americano Flaherty, que tinha sido enviado a trabalho ao Canadá para trabalhar com mineração, mas acabou depois se voltando à filmagem do povo nativo Inuit, o francês Jean Rouch era um engenheiro quando foi enviado à África para construir estradas e pontes para o poder colonial francês no Níger. As relações coloniais dos territórios filmados foram determinantes para os dois cineastas. No Níger, Rouch entra primeiro em contato com a religiosidade e medicina nativas, para depois estudar etnologia em Paris com Marcel Griaulle, um dos pioneiros do filme etnográfico. Os primeiros filmes de Rouch são filmes etnográficos tradicionais, com a filmagem de rituais, por exemplo, acompanhadas de narração em off do antropólogo, no caso, ele mesmo.

Rouch imprime um novo estilo aos filmes quando traz para seu trabalho o que cunhou de “antropologia partilhada”. Essa forma de trabalhar na produção dos filmes incluiu caracterizava-se por trazer os sujeitos filmados para pensar a construção dos filmes. Essa estratégia de produção, onde em que a mise-en-scène construída coletivamente pelo cineasta e personagens do filme, tinha sido iniciada por Flaherty, mas Rouch foi quem a levou a novos patamares de experimentação. Alguns dos aspectos de 
caráter experimental, como no filme Jaguar (1967), aconteceram também devido a dificuldades técnicas, como a falta de som sincronizado. Elas seriam, superadas muitos anos depois pela gravação que Rouch fez dos comentários dos seus personagens ao corte montado do filme, incorporados ao filme finalizado. Em Jaguar a tônica é a improvisação pelos sujeitos filmados, assim como pelo cinegrafista, no caso o próprio Rouch. Em seu próximo filme seguinte, Eu, Um Negro (1958), ele leva assume tanto a improvisação de situações já experimentada em Jaguar quanto a dramatização planejada - legado herdado de Flaherty - a novos limites. Rouch dessa forma trazia novamente os sujeitos/personagens para a partilha da construção de seus filmes. Desse modo,

o “outro" deixa de ser apenas objeto do registro, mesmo que contribuindo para que este aconteça - como nos filmes de “registro etnográfico” - e passa a ser “inventado”, construído pelo cineasta e por ele próprio. Não é preciso dizer que, tanto num quanto noutro existe construção de uma realidade fílmica, uma realidade que não é propriamente aquela do mundo histórico. A diferença entre os dois está justamente na explicitação dessa invenção, na eleição dessa invenção como condição prévia para a existência mesma do filme (FREIRE, 2007, p. 60).

Como aponta Amir Labaki (2006, p. 60), “da “antropologia compartilhada”, Rouch estabeleceu o “documentário compartilhado”. A esse modo de produção, de seus filmes Rouch cunhou a tipologia Cinéma Vérité, o “cinema verdade”, equivalente ao conceito Kino Pravda russo de Dziga Vertov, um dos precursores do documentário, para quem o cinema produzia uma nova verdade, a "verdade do filme”, criada a partir da presença da câmera. Jean Rouch dizia que buscava combinar a teoria de Vertov com o método de Flaherty. Com Vertov, Rouch aprendeu que a câmera cria seu próprio ponto de vista, que traz ao mundo algo novo, uma produção que não estava ali antes da câmera chegar. Aprendeu também que a, e da montagem atuar também sobre as imagens. A verdade cinematográfica, para Vertov, é sempre uma produção que se dá no ato da filmagem e da montagem. Ela parte dos “fatos da vida”, mas é pela montagem que se chega às “coisas fílmicas”. Na linha do pensamento marxista, Vertov, assim como Sergei Eisenstein, pensavam o filme como resultado quase imaterial, ideológico, de um processo 
que paradoxalmente começa no material filmado pela câmera e termina com uma produção audiovisual que deve intervir novamente no mundo material. Porém, diferente de Vertov, Rouch não aceitava apenas os “fatos da vida” capturados pela câmera, mas os instigava, os produzia tais fatos, mesmo que conjuntamente com os sujeitos filmados ou a partir desconsiderando suas ações deles, como Flaherty fazia.

Com o advento da sincronização do som com a imagem, especialmente com o lançamento dos gravadores de som direto no final dos anos 1950, começaram a ser produzidos filmes com estilos tão diferentes no estilo como quanto Primary, da Drew Associates, e Crônicas de um Verão, de Jean Rouch e Edgar Morin. Nascia o "Cinema Direto", com os americanos e sua metodologia que ficou conhecida como "mosca na parede $^{13 »,}$ de filmagem “objetiva”, e chegava ao ápice o estilo de Rouch, chamado “Cinema Verdade”, em que a câmera incita ações e reações, participando ativamente da produção de situações. As duas novas tradições do documentário romperam, ao menos parcialmente, com o modelo de John Grierson ao buscar ouvir sobre a interioridade e as visões particulares de indivíduos, seus sentimentos e pensamentos. Trata-se de dois métodos ou dispositivos bem diferentes, quase simetricamente opostos. Quase, porque o Cinema Direto, ao mesmo tempo em que tem um estilo “objetivo" na forma de filmar e no modo de montar, ainda assim reconhece, na fala de seus autores reconheciam, que suas a escolhas das pessoas e situações eram subjetivas. De outro lado, o Cinema Verdade, por mais que incitasse as pessoas a ações que vinham da própria direção dada pelos cineastas, não deixa por isso de ser interpretado como uma produção sobre o mundo "objetivo" das pessoas.

O filme Titicut Follies (1967), assim como Hospital (1970), e outros filmes do cineasta do Cinema Direto Frederick Wiseman sobre instituições, uma característica da sua produção, demonstram como esse legado nunca consegue ser apenas objetivo: a angulação da câmera, os planos em seus enquadramentos e durações, mais a montagem em termos de suas sequências, tudo acaba por criar uma narrativa, e narrativas são sempre construções de autores. Além do mais, o que as narrativas do Cinema Direto realizam é a criação de um espaço interpretativo que alguns receptores, alguns públicos desses filmes vão preencher com o paradigma da “objetividade”, embora na prática de maneira diversa conforme as subjetividades diversas desses públicos. Os Outros

\footnotetext{
${ }^{13}$ O conceito “mosca na parede” descreve o modo de produção de documentários característico do Cinema Direto, em que a câmera e os cineastas se comportam de modo a não interferir nem aparecer na cena, como se não estivessem presentes. Alguns, como Frederick Wiseman, argumentaram que "mosca na parede" é "o termo mais depreciador (...) nenhuma das moscas que conheço são conscientes”.
} 
apresentados, as pessoas internadas no hospital psiquiátrico para criminosos no filme Titicut Follies, por exemplo, muitas vezes não têm como avaliar ou muito menos decidir sobre o uso de suas imagens. No entanto, ainda no caso específico desse filme, essa mesma injunção foi usada para censurar o filme por muitos anos, pois Titicut Follies trazia também um potencial de crítica à própria instituição do hospital psiquiátrico, muitos sendo fechados nos EUA Estados Unidos em função dos efeitos do filme. Enquanto o Estado acusava o filme de não respeitar os sujeitos filmados, muitos espectadores acusavam a própria instituição filmada de não respeitar os mesmos sujeitos. No filme Hospital, apesar de não haver comentários do cineasta, não temos como não jogar nossos próprios valores e julgamentos sobre o Outro que aparece faz-se visível à nossa frente. Pois já temos nossos conceitos e pré-conceitos sobre pessoas de todos os tipos, em todas as situações, especialmente se somos mais que alfabetizados, ou mesmo bombardeados constantemente, por diversas mídias.

Usando uma metodologia quase oposta, e com o recurso da gravação do som sincronizado em mãos, Jean Rouch e Edgar Morin realizaram um filme que é considerado o marco inicial do Cinema Verdade e que foi feito como uma antropologia que volta para casa para estudar o Outro “em casa”. Eles andam por Paris, entrevistam pessoas conhecidas e desconhecidas com uma atitude forte, perguntas e interferências diretas sobre esses sujeitos filmados. “As pessoas em frente à câmera e nós na audiência somos continuamente lembradas que um filme está sendo feito, que estamos a ver um filme” (ELLIS \& MCLANE, 2005, p. 215). Jean Rouch continuava a exercer a "verdade do filme” que tinha aprendido com Vertov, reconhecendo que um filme é sempre uma nova produção sobre o mundo, com o acréscimo da participação dos sujeitos filmados na construção dessa "verdade", metodologia de trabalho aprendida de Flaherty e da antropologia. Embora consideremos que essa tendência fosse ainda incipiente na própria antropologia, que tinha naquela época ainda a auto-incumbência de falar pelo Outro, ou seja era uma antropologia colonial que servia ao colonialismo.

Ao mostrar a construção do filme, seus bastidores, Rouch não transformava por isso seu filme em ficção. Ele apenas mostrava que filmes são construções sobre o mundo, apoiadas no mundo, mas sempre construções. Mais que isso, ele acreditava que era preciso atuar ativamente sobre personagens para chegar a essas construções cinemáticas, para chegar a alguma "verdade”, pois para Rouch havia, por mais paradoxal que pareça, verdade na encenação fílmica. Os encontros e desencontros do Cinema Direto com o 
Cinema Verdade acontecem de várias formas. Como bem formulou Erik Barnow (1993 apud LABAKI, 2006, p. 60):

O documentário do Cinema Direto levava sua câmera para uma situação de tensão e torcia para uma crise; a versão de Rouch do Cinema Verdade tentava precipitar uma. O artista do Cinema Direto aspirava à invisibilidade; o artista do Cinema Verdade de Rouch era frequentemente um participante assumido. O artista do Cinema Direto desempenhava o papel de observador neutro; o artista do Cinema Verdade assumia o de provocador.

O filmes brasileiros até os anos 1920 eram silenciosos e feitos sob encomenda, em que os interesses institucional ou comercial reinavam. A partir de 1930, alguns documentaristas, entre os quais destacamos Humberto Mauro, produziam filmes ao modo de Grierson, com vertente pedagógica-educativa. Nos anos 1950, Humberto Mauro passou a produzir filmes com vertente mais documental, no sentido de registro de culturas do Brasil. A representação do Outro em filmes de sua autoria que compõem a série Brasilianas era romantizada, talvez em razão da projeção de sua própria visão de mundo: "Brasilianas são a quintessência do documentarismo mauriano, que afirmava buscar com seus registros “o reencantamento do mundo”. O Brasil de Mauro é um país mítico. Um país rural, harmônico, idílico, em que homem e natureza convivem em absoluta paz - numa palavra, o interior de Minas e sua infância.” (LABAKI, 2006, p. 40). Nos anos 1950, produzida por Thomaz Farkas, a Caravana Farkas realizou filmes sobre culturas tradicionais do povo brasileiro que, segundo o produtor, corriam risco de desaparecer. O Outro - de cultura tradicional - em vias de desaparecer é um dos grandes temas do documentário brasileiro.

O legado de representar povos tradicionais, rurais ou pesqueiros, foi levado adiante em dois filmes que marcam a história do documentário no Brasil: Arraial do Cabo (Direção Mário Carneiro e Paulo César Saraceni, 1959) e Aruanda (Direção Linduarte Noronha, 1959). Arraial do Cabo é considerado uma das grandes inspirações do Cinema Novo, realiza uma representação do Outro (que no Cinema Novo viria a ser o “povo”) em que este Outro vive um conflito e dualidade entre a tradição e a modernidade. A tomada de lado é pela “tradição”. Já o filme Aruanda se restringe-se a ser mais um documentário de imersão numa cultura no sentido de se estar preso apenas às pessoas da 
Serra do Talhado que vivem a seca do semiárido. Os dois filmes marcaram época no sentido de trazer o enfoque num Outro - o “povo” do Brasil.

Foi a partir dos anos 1960 que o Cinema Novo produziu filmes com inspiração nas possibilidades do som direto exploradas pelo Cinema Direto e Cinema Verdade. O som direto possibilitou ainda mais o foco à representação do Outro - o "povo" - que o cinemanovismo herdou como legado dos anos 1930 a 1960.

Com [o filme] Maioria Absoluta, Leon Hirszman realizou talvez o primeiro exemplo acabado de Cinema Verdade no Brasil. Se “é bem CPC”, como reconheceu Hirszman, o é em novo estilo. O próprio cineasta o reconhece ao frisar o "som direto" neste "cinema documentário da realidade" em que busca "que os outros tivessem voz, com uma compreensão do mundo mais ampla (LABAKI, 2006, p. 52).

A mudança trazida pela inserção da voz sincrônica do Outro no documentário possibilitou novos tipos de filmes. Se antes o documentarista precisava de um certo planejamento do filme pensando antecipadamente sua montagem, talvez até roteirizando a montagem, com o som direto sincrônico outras possibilidades surgem. E com elas surgiu também Eduardo Coutinho, o grande mestre das entrevistas sem roteiro. Um filme como O Fim e o Princípio (2006) só é possível pelo som direto que permite ao cineasta trabalhar sem pré-concepções sobre o Outro. No caso desse filme, o Outro é definido apenas pelo local onde mora. O dispositivo utilizado por Coutinho no filme é de apenas escolher apenas o vilarejo onde vai realizar as entrevistas, sem saber muito previamente sobre o local. Nesse sentido, podemos dizer que o dispositivo está criando o Outro para o filme - dispositivo que, nesse caso, envolve a presença do diretor numa conversa, e a câmera, o sujeito filmado como co-criador da "verdade da filmagem” (COUTINHO 2013, p. 23). Para Coutinho, a montagem do documentário, que inclui o apelo a uma narrativa, por isso mesmo tem um certo teor de ficção, pois toda narrativa é uma criação após o ato da filmagem mesma (COUTINHO 2013, p. 27). Coutinho adotou para si como regra o “cinema de conversação”. Diz ele:

Escolhi ser alimentado pela fala-olhar de acontecimentos e pessoas singulares, mergulhadas na contingência da vida. Eliminei, com isso, até onde fosse possível, o universo das ideias gerais, com as quais 
dificilmente se faz bom cinema, documentário ou não, e dos "tipos" imediata e coerentemente simbólicos de uma classe social, de um grupo, de uma nação, de uma cultura. O improviso, o acaso, a relação amigável, às vezes conflituosa, entre os conversadores dispostos, em tese, dos dois lados da câmera - esse é o alimento essencial do documentário que procuro fazer. O que não exclui, é claro, uma ideia central, prévia à filmagem, que preside a construção do filme mas que não passa de uma hipótese de trabalho a ser testada na prática desses sucessivos encontros com personagens de carne e osso (COUTINHO, 2013, pp. 15-16).

O Outro de Coutinho é um Outro específico. O dispositivo - a escolha do local onde se dão, e de que forma se dão as entrevistas, e com quais pessoas, tudo isso gera o Outro com os quais Coutinho dialoga, particularmente em seus últimos filmes, sem querer criar uma representação geral sobre o Outro enquanto tipo de pessoa, ou grupo a que pertence. O Outro de Coutinho só tem utilidade para o momento da filmagem e do filme em si. Ele não está em busca de se tornar um aliado de uma ou mais pessoas. Está ali apenas para conversar e ver o que sai, esperando ser surpreendido:

Creio que a principal virtude de um documentarista é a de estar aberto ao outro, a ponto de passar a impressão, aliás verdadeira, de que o interlocutor, em última análise, sempre tem razão. Ou suas razões. Essa é uma regra de suprema humildade, que deve ser exercida com muito rigor e da qual se pode tirar um imenso orgulho (COUTINHO, 2013, p. 20).

Eduardo Coutinho representa uma parte dos dos documentaristas que aprendeu que falar pelo Outro é problemático. Junto a outros cineastas, como João Moreira Salles, incluído nesse grupo, critica o que chama de “documentário militante”. De origem griersoniana, o termo refere-se a filmes que, antes de ouvir o Outro, já sabem o que buscam e o que querem ouvir. Desse modo, documentaristas militantes criam filmes de “pedagogia utilitária”, termo utilizado por Salles (LABAKI, 2006, p. 89). Salles é o diretor de um filme que virou referência quando se fala em representar um Outro e suas implicações em termos de relação de poder. Em seu filme Santiago (2007), mostra como lhe foi difícil pessoalmente realizar um filme sobre seu mordomo. Seus enquadramentos, 
a distância que mantinha do sujeito filmado Santiago, suas perguntas e modo de se relacionar, tudo é refletido no filme para mostrar como a produção da representação de um Outro envolve implica relações sociais e posicionamentos que às vezes não estão conscientes para o cineasta. Só muitos anos depois de filmar, Salles consegue fazer uma montagem e narração que reflete muito mais sobre sua dificuldade em fazer esse filme e os bias, pré-concepções ou pré-determinações que ele carregava ao filmá-lo, do que propriamente um filme sobre Santiago. Talvez, na época da filmagem, sua amizade e respeito por Santiago se impusessem e refreavam a possibilidade de Salles finalizar o filme. As construções e efeitos na representação de um Outro às vezes ficam mais aparentes em suas construções e efeitos quando o cineasta é próximo o bastante do sujeito filmado para saber enxergar que o que estamos fazendo é uma construção sobre esse sujeito.

A possibilidade da neutralidade na representação do Outro já é, há muito tempo, colocada em xeque nos estudos culturais, pós-coloniais e pós-estruturalistas, na crítica literária e por pensadores da cultura Ocidental (CLIFFORD, 1986; 1988). Essa neutralidade, em certas instâncias se mostra-se, em certas instâncias como relações de opressão e subalternidade, como formadora e sustentadora de esquemas de poder. Seja na representação do Outro como “indígena”, “nativo”, “primitivo” ou "selvagem” (CHURCHILL, 1998; TORGOVNICK, 1990), seja na representação do Outro como “oriental”, “árabe”, “terrorista” (SAID, 2003), seja na representação do Outro como “preto”, “negro”, “africano” (FANON, 2007; HALL, 1997; HOOKS, 1992), todas essas representações existem em relações de dominação colonial, capitalista, patriarcal. O Outro que é mostrado num filme nunca existe num vácuo de poder. Por essa mesma razão, pelas porque as relações de poder sempre estarem estão “lá” em qualquer representação, não existe um método perfeito para realizá-la. Sempre haverá espaços de diferença e contestação a se apresentar seja na produção, seja na recepção dos filmes. Da maneira como estamos concebendo, o Outro não é fixado nem tornado transparente por um filme. Pelo contrário, embora sempre haja discursos dominantes sobre o Outro, estes estão em constante deslocamento e readaptação em relação a outros Outros. Embora o cinema norte-americano tenha produzido suas imagens sobre o Outro indígena, o Outro oriental e tantos outros Outros, esses são produzidos também um em relação ao outro, em que pese a contingência do momento histórico. 
Enquanto o Wild West [ocidente selvagem ou faroeste] se tornou politicamente correto, com uma abundância de filmes revisionistas dos anos 60 e 70 retratando cowboys negros, homens brancos se tornando indígenas, a indígenas compassivos e heróicos, o Wild East [oriente selvagem] se tornou ainda mais bárbaro, especialmente depois de Guerra Árabe-Israelense de 1973 e o subsequente embargo de petróleo (GRAHAM, 2010, p. 86, tradução nossa).

A autorreflexividade sobre a construção do Outro em documentários já tinha sido parte da tradição fílmica ao menos desde os filmes de Jean Rouch. Porém, observamos que um outro tipo de reflexividade vem à tona com as produções realizadas a partir dos anos 1960 com a ascensão de diversos movimentos sociais pelo mundo, inicialmente aliados entre eles contra a Guerra do Vietnã, depois voltando-se cada um para suas questões “em casa”. Com diferenças entre países no modo em que circunstâncias cada movimento pôde ou não se realizar, lutas por libertação nacional e contra a colonização nos países africanos e asiáticos, principalmente, o movimento de direitos civis contra o racismo nos Estados Unidos, de mulheres, gays e lésbicas por diversos países, o nascente movimento ambientalista, todos (res)surgem e encontram no documentário um modo não somente de se expressar, mas de lutar por direitos e políticas.

Surgem filmes feitos por mulheres cineastas numa maior expressividade, especialmente filmes sobre outras mulheres. Os anos 1970 viram uma nova produção surgir, especialmente nos Estados Unidos. Os filmes frequentemente envolviam as relações das cineastas com suas mães ou avós, como faz Amalie Rothschild em Nana, Mom, and Me (1974). O Outro aqui como mãe e avó já não é tão outro assim, é alguém de casa que revela relações de construção de identidade e alteridade. Os estereótipos de “virgem”, “esposa”, “mãe”, “femme fatale” já eram desafiados nos anos 1970 e 1980 por filmes que buscavam desconstruir esses Outros do discurso dominante sobre a mulher (NICHOLS, 2010, pp. 399-429). Os documentários por mulheres cineastas não se fecharam apenas nas questões de gênero, mas na maior parte trataram de questões diretamente ligadas às mulheres, especialmente na década de 1970 (JACOBS, 1979, p. 517). Uma característica que aparece muito nos documentários realizados por mulheres na década de 1970 é a reflexividade, é a presença do lugar da cineasta em relação às posições ocupadas pelos sujeitos filmados. Pois sendo a cineasta ela mesma mulher, um Outro para a sociedade dominante patriarcal, sua condição, quando refletida pela 
cineasta, aparece entremeada por esforços de resistências a uma sociedade machista. A cineasta frequentemente se coloca em frente à câmera ao modo do Cinema Verdade, ou deixa suas perguntas e comentários a pessoas entrevistadas audíveis na montagem para se fazer presente.

A realização do documentário por mulheres não se limitava a explorar questões excessivamente pessoais ou familiares. Diferentemente do que quereria um sexismo que encontrando nisso nessa temática mais um sinal de que a mulher como está mais ligada à emoção/casa/família/subjetividade do que o homem, que seria tomado como seu oposto simples, a realização do documentário por mulheres não se limitava a explorar questões excessivamente pessoais ou familiares. O que as mulheres cineastas dos anos 1970 conseguiram foi trazer a perspectiva feminina sobre diversos assuntos, que incidem inclusive sobre a vida dos homens, no modo como os poderes e as instituições dominantes estão estruturados. Nessa perspectiva reflexiva, dominante entre cineastas mulheres, não há neutralidade ou objetividade possível - ou mesmo desejável. O entendimento é de que o neutro se mostra, pois sua ligação é com o dominante, com a manutenção do status quo. E quando as cineastas tomam para si o questionamento do status quo, que é necessariamente machista, patriarcal, são chamadas de feministas ou assumem isso para si mesmas. Pois “o feminismo é um movimento para acabar com o sexismo, exploração sexista, e opressão”. A autora bell hooks continua:

Eu amo essa definição, que eu apresentei pela primeira vez há mais de 10 anos, em meu livro Feminist Theory: From Margin to Center. Eu a amo porque afirma claramente que o movimento não é sobre ser antimasculino. Deixa claro que o problema é sexismo. E essa clareza nos ajuda a lembrar que todos nós, do sexo feminino e masculino, temos sido socializados desde o nascimento para aceitar o pensamento e a ação sexistas. Como consequência, as fêmeas podem ser tão sexistas quanto os homens. E embora isso não desculpe ou justifique a dominação masculina, significa que seria ingênuo e equivocado para pensadoras feministas ver o movimento de forma simplista como sendo as mulheres contra os homens. Para terminar o patriarcado (outra maneira de nomear o sexismo institucionalizado) nós precisamos estar claros de que somos todos participantes na perpetuação do sexismo até que mudemos nossas mentes e corações, até deixarmos o pensamento e 
ação sexistas e substituí-los com pensamento e ação feminista (HOOKS, 2000, p. viii, tradução nossa).

Documentários se mostraram particularmente efetivos em seu uso por grupos e comunidades marginalizadas, como a de lésbicas, gays, bissexuais, transgêneros. Nos anos 1980, filmes que tratam de uma complexidade de identidades e de opressões começam a ser produzidos em quantidade. O filme Tongues Untied (1989), do cineasta Marlon Riggs, marcou época por tratar ao mesmo tempo de homofobia, racismo e sexualidade não-dominante, misturando estilos diferentes de documentário experimental, poético, autobiográfico e histórico, e foi censurado em diversos espaços, mostrando que aquele Outro criado como o estereótipo do gay, o "homem branco gay" - que ofuscava a visibilidade de lésbicas (chamadas de gays) e de todas as outras existências de sexualidade -, por mais dominante que fosse, o branco gay, não conseguia eliminar a existência de homens negros gays, bissexuais etc. A essa maneira de mostrar que ao em relação ao Outro dominante existem variações e silenciamentos, que a figura do homem gay não é unívoca ou homogênea, se seguiram-se diversas produções que fazem emergir o não-dominante como existente. Os grupos que sofrem diversas formas de opressão, tais como sexismo, racismo, heterossexismo ou uma combinação destes, justamente por suas experiências mais marginais em relação à cultura dominante, produziram também alguns dos filmes mais dissonantes em contraposição às dominações, tanto nos aspectos estilísticos, narrativos, cinematográficos, quanto nos socioculturais.

Assim é que muitos cineastas queer, por exemplo, recusam a univocidade, seja das palavras, seja das imagens. As palavras podem ser usadas para contradizer imagens, ou imagens podem contradizer palavras, ou ainda imagens podem estar a contradizer imagens e palavras outras palavras. Por exemplo, a experiência de uma pessoa transgênero é muitas vezes vista como fazendo parte de um gênero, mas se sentindo de outro. Ou ainda, uma pessoa pode não se reconhecer dentro do binarismo masculino/feminino, e dessa forma nunca se sentir representada pela cultura dominante. Mas, o Outro sempre é encaixado pelo dominante em alguma posição de sujeito prémoldada (e essas posições atingem a todos de diferentes formas):

Aparências enganam. A identidade cultural “queer” e a problemática do documentário contemporâneo convergem nesse ponto (platônico). O fenômeno da presunção heterossexual (alguém é heterosexual até que se 
prove o contrário) frequentemente coloca os sujeitos queer numa posição que mimetiza e inverte a estrutura da ironia dramática. Presumido heterossexual, o sujeito queer se torna um ator numa cena encenada por um outro, pelo imaginário cultural de um outro. No entanto nessa cena, o ator sabe mais, é mais do que o público dele ou dela, mais do que a cultura dele ou dela imagina. Um efeito de conhecimento, que mina a coerência presumida da identidade em si, emerge da dinâmica da encenação: o de quem o sujeito não é.

(...)

No documentário experimental lésbico e gay, estas ironias - subjetivas, afetivas, e representacionais - convergem. Cineastas queer talvez sejam afiadas na não-ficção experimental, reflexiva por conta de sua experiência vivendo em subjetividades reflexivas e retóricas. Assim esses trabalhos apresentam um campo particularmente rico para a investigação de táticas efetivas em produção de filmes e vídeos de nãoficção experimentais em geral, porque interrogam a representação tanto em relação à mídia e em relação aos sujeitos do trabalho (MACHUGH, 1997, p. 224, tradução nossa).

Tratamos da possibilidade de um cinema documental com olhar queer, com o cuidado de referenciar a partir de nosso lugar de fala, como pesquisador-cineasta aliado da comunidade queer que não é parte da comunidade, e com o cuidado para aqui não inferir que estamos falando de todas as pessoas queer ou que a cineasta é determinada, pela sua condição, a ser de uma maneira apenas. Uma pessoa queer tem a todo tempo que lidar com o Outro que ele/a não é. Uma experiência que pode levar uma pessoa a questionar a própria subjetividade assim como toda objetividade como historicamente conjunturais. Isto é, uma identidade, e com ela um filme que se versa sobre identidades, só se faz no aqui e agora e todas as suas aparências conjunturais e contextuais. A cineasta queer trabalha muitas vezes pela quebra do discurso unitário e unívoco, seja usando a dissonância entre sons, imagens, palavras uns com os outros, seja trabalhando com diferentes regimes de representação, fazendo dos seus encontros e desencontros os pontos onde em que a univocidade é impossível, mas podemos dizer que também a univocidade da cultura dominante fica impossível. Cineastas como Joyan Saunders, com seus filmes Here in the Southwest e também Brains on Toast: The Inexact Science on Gender, utilizaram muito sabiamente as possibilidades de desconexão inerentes ao audiovisual 
como um duplo áudio/visual, aproveitando para colocar em desconstrução outros duplos como subjetividade/objetividade, emocional/racional. Saunders foi mestre em desmontar a suposta objetividade tanto dos discursos científicos sobre sexualidade, quanto da produção de discursos documentais sobre o Outro.

Ao ligar a documentação visual a falácias retóricas, aparência com decepção, visibilidade com demonstrações do que não sabemos ou não podemos saber sobre os sujeitos retratados, todas essas cineastas registram uma lição profunda e crucial sobre identidade queer e documentário. As únicas verdades que podem ser contadas sobre identidade e verdade são limitadas, e as declarações mais verdadeiras, a mais veraz documentação, só pode documentar essas limitações. Trabalhando no interior/nesses nãos todos, todas essas impossibilidades, essas cineastas gesticulam ao que foi deixado de fora, não recontado, não visto, um sujeito muito elusivo e queer (MACHUGH, 1997, p. 240, tradução nossa).

Para grande parte de cineastas queer, gays e lésbicas, assim como negros, indígenas e mulheres, não existe a opção da imparcialidade ou neutralidade. Pois o seu próprio ser é uma questão para ele/a/x, enquanto um Outro da cultura dominante. Enquanto nãodominante, sua existência é rica em contra-memória, a memória de grupos subalternizados e não dominantes e que se apresenta em sua diferença ao dominante, não buscando ser o dominante, não buscando a identidade do Mesmo (FOUCAULT, 1977), por isso contém formas de resistência a formas do Outro impostas a si por sua própria vivência. “A documentação da contra-memória experienciada por pessoas marginalizadas cujas histórias são largamente ignoradas é um terreno delicado que deve ser navegado cuidadosamente. A questão de “"no interesse de quem”” uma história está sendo construída deve ter precedência” (AGUAYO, 2014, p. 176). Pois mesmo no caso dos filmes que romantizam ou idealizam o Outro, com quais interesses isso é feito? Em relação à representação do Outro “primitivo” construído pelo Ocidente, como Torgovnick apontou em Gone Primitive, o discurso sobre o "primitivo” tem sido um que usa um tipo de dualismo de nós/eles, onde o textualmente “nós”, têm sido principalmente uma pessoa “européia, ou de ascendência européia, branca, alfabetizada, educada, de classe média ou acima” (TORGOVNICK, 1990, p. 4). 
A representação sobre o Outro se mostra sempre interessada, nunca imparcial. Essa percepção da impossibilidade da neutralidade fez documentaristas como Rouch caminharem para a ficcionalização realizada de forma compartilhada. No entanto, o que Rouch não compartilhou foram os projetos e os efeitos desejados de seus filmes. Ao deixar de pensar nos efeitos desejados, à vida que teriam seus filmes, Rouch deixou ao acaso, ao modo do Cinema Direto do qual foi contemporâneo, a vida que seus filmes tomariam, os rumos possíveis e enfrentamentos pelo mundo tomados por eles. Por mais que se olhe para as diferenças entre o Cinema Direto e o Cinema Verdade em termos de métodos de produção entre o Cinema Direto e o Cinema Verdade, um e outro tinham uma fé profunda no nascimento espontâneo dos filmes a partir da escolha dos Outros como sujeitos filmados. Descrevendo sobre um debate acalorado entre Jean Rouch e Richard Leacock, que foi um dos fundadores do Cinema Direto, os historiadores do documentário, Jack Ellis e Betsy MacLane (2005, p. 217, tradução nossa) relatam que

ambos esperavam encontrar a "realidade da vida", “a verdade nas pessoas” escondida sob as convenções superficiais da vida cotidiana. Rouch buscou perfurar a superfície observável para chegar a essa verdade subjacente por meio de discussão, entrevista, e uma espécie de improvisação ficcional. Leacock pensava que poderia capturar essa mesma realidade obscurada fotografando pessoas sem se intrometer; que sujeitos revelariam o que realmente sentiam e eram quando relaxados sem auto-consciência ou profundamente envolvidos em alguma atividade. Rouch buscava desmascarar a verdade através de um processo de auto-revelação [do Outro] deliberadamente encorajada. Leacock tentou expor essa realidade pela captura de momentos de autorevelação sem defesas no movimento da vida vigente. Rouch queria explicar a raison d'être da vida, enquanto Leacock queria deixar a vida revelar a si própria.

Tanto o Cinema Direto quanto o Cinema Verdade tem como seus paradigmas a verdade como algo que é produzido por um filme. A diferença é como se dá a produção da verdade, mas essa é sempre uma verdade sobre o Outro filmado - e com Nietzsche dizemos que verdade não depende apenas de intenções, mas sim de criação. Para o Cinema Direto, essa produção é vinda da própria espontaneidade do Outro e das circunstâncias em que ele se encontra. Para o Cinema Verdade, a produção da verdade do 
Outro é uma invenção da qual participam tanto o Outro quanto o cineasta, não sendo por isso menos verdadeira a "verdade do filme" de Rouch. Paradoxalmente, enquanto a produção do Cinema Direto busca o efeito do "naturalismo", para a "invisibilidade dos meios de produção desta realidade” (XAVIER, 2012, p. 41) do filme bem ao estilo mais consagrado por Hollywood, por outro lado o Cinema Verdade, mais influenciado pelo movimento do cinema russo do início do século $\mathrm{XX}$, não acredita que apenas a observação da realidade é o bastante, coloca o cinema enquanto produtora ela mesma dessa realidade, o que "implica na admissão de que há um trabalho produtivo por trás da representação artística” (XAVIER, 2012, p. 58). Isto é, as duas tradições do documentário depositam um investimento na produção da verdade pelos filmes, porém estão em desacordo sobre como chegar à verdade.

Mas o que poderia conferir aos documentários essa crença na produção da verdade aos documentários, principalmente agora que tinham o som sincronizado como recurso? O que o som sincronizado possibilitou, em conjunto com as metodologias tanto da “mosca na parede” quanto do "documentário compartilhado", foi a produção de narrativas. Pois

com o advento do cinema verdade/direto as distinções agudas entre documentário e ficção (...) foram ofuscadas. Oferecendo uma relação próxima à vida enquanto vivida, os filmes do cinema verdade/direto são preponderantemente, quase automaticamente, narrativos em forma. Eles mostram algo acontecendo, seguido por algo mais que acontece, seguido por mais algo, e por aí vai. Pessoas no cv/direto são apresentadas atuando e reagindo umas às outras, de maneiras análogas ao comportamento de personagens nas ficções em dramas (ELLIS \& MCLANE, 2005, p. 222, tradução nossa).

O formato narrativo, que no documentário nasceu com Flaherty, embora sem a força dos diálogos em Nanook, não demorou para ser novamente questionado. Os filmes de Wiseman, já citados anteriormente, como Titicut Follies, tinham retornos dos públicos que eram muito contraditórios entre si. As narrativas dos filmes cinema verdade/direto têm seus comentários implícitos tanto no modo de capturar imagens quanto na montagem, porém não podem controlar a recepção e a interpretação dos públicos, que pertencem a diferentes “comunidades interpretativas” (FISH, 1980). A evolução dessas 
comunidades em termos de capacidade reflexiva sobre o audiovisual possibilitou aos documentaristas experimentar com novas formas, e os documentários foram eles mesmos protagonistas dessa evolução de possibilidades de interpretação e experimentação. A expectativa de que um documentário fale sobre a "realidade" criou também, paradoxalmente, a possibilidade de quebrar ou retornar a essa mesma expectativa. No final dos anos 1960 surgem os primeiros “mockumentaries”, conhecidos também como “falsos documentários”, em que há criações de situações falseadas feitas especialmente para os filmes como estratégia narrativa. Os “falsos documentários” fazem uso nessas situações da própria estética do documentário, com a câmera ficando por um momento fora da ação que ocorre fora para além de seu controle, ou pela adoção do estilo de movimento de câmera mais mexido e irregular, indicando a filmagem improvisada. Observamos que, e essa estética passou a ser usada hoje em dia até em filmes de ficção que recorrem a ela para com isso se ligar à "realidade” de alguma forma. O interessante é que documentários poéticos ou performáticos, no entanto, pouco ou nada se prestam enquanto recursos para apontar de forma clara ao documentário como linguagem, pois estes se confundem mais facilmente com a estética das ficções.

Para alguns autores, o que faz um documentário ser documentário é como o público recebe e interpreta o filme, o que chamamos em estudos do cinema de recepção. Para Brian Winston (1995, p.253), “são os públicos que podem dizer a diferença entre uma narrativa ficcional e um argumento documental. Em outras palavras, é uma questão de recepção. A diferença deve ser encontrada na mente do público.” Contra essa tese, Bill Nichols (2012, p. 26) afirma que “todo filme é um documentário”. Podemos compreender tal posicionamento teórico se pensarmos os documentários como resultados ou produções de culturas específicas a um tempo e espaço. Nenhum filme é feito sem buscar referências em seu contexto sociocultural, mesmo que seja para negar ou opor-se às produções culturais desse contexto.

Dito isso, podemos considerar que mesmo filmes de ficção acabam por reagir ou até interferir às conjunturas mentais, sociais, culturais e políticas e, enfim, dialogam com o que por vezes se entende como "realidade", mesmo que entendamos que ela seja sempre produzida pelo imaginário cultural. Não é nosso objetivo e, ou talvez não seja uma tarefa possível, dizer determinar se Nichols está certo ou errado ao afirmar que todo filme é um documentário. Podemos admitir, por princípio, que todo filme busca causar algum impacto no espectador, ou que todo filme precisa de um espectador. Só pelo fato de ser produzido para ser visto, para causar uma impressão, seja essa qual for, um filme é 
feito para se tornar um discurso que, a exemplo de obras literárias, como que acaba por assumir uma vida própria, em que a sua produção determina seus caminhos mas apenas parcialmente, não é sobre-determinante, pois filmes têm efeitos múltiplos e contraditórios nos diferentes contextos socioculturais em que se inserem. Na mesma linha, porém em pólo oposto, há estudiosos que afirmam serem os documentários sempre ficcionais, pois ficções podem ser entendidas como "os rearranjos materiais dos signos e das imagens, das relações entre o que se vê e o que se diz, entre o que se faz e o que se pode fazer" (RANCIÈRE, 2005, p. 59). Nesse sentido, ficcionalizar é sempre parte da arte do falar sobre e do fazer cinema. Porém, é necessário também notar um uso do conceito de ficção para o documentário, quando se coloca que fazer ficção é fazer algo para além/aquém do real. Dizer que documentários nunca falam/lidam com o real, é uma afirmação que busca muitas vezes isentar e até desculpar previamente os documentários de por qualquer efeito (ou falta de efeitos vislumbrados) sobre o mundo vivido pelas pessoas.

Entender todos os filmes como documentários, ou entender todos os filmes como ficção, não precisam ser compreensões excludentes. Somente o idealismo de um fazer e um ser universal para o que se convém chamar de documentário pede que pensamentos supostamente opostos neguem um ao outro. De outro modo, parece-nos que a produção de documentários é inerentemente dúbia entre ser ele uma intervenção no mundo sociocultural e político, ao mesmo tempo em que é uma história que pode tocar nesse mesmo mundo (se é que o mundo é unívoco, assim como nossa linguagem e língua por vezes exige quando dizemos “o mundo”) apenas como isso: uma história, tocando a cada sujeito de maneiras ligeiramente ou até absurdamente diferentes. Pois um filme não é nada sem sua recepção. E essa recepção faz tanto parte do filme quanto todo o seu contexto de produção. O que une os dois contextos, produção e recepção, é o mundo vivido $^{14}$. Um documentário se alicerça sobre o mundo vivido para fazer recortes, comentários, produzir reflexões e até ações sobre contextos pessoais, sociais, culturais e históricos específicos. Por mais que um documentário envolva encenação ou até mesmo sátira do mundo vivido (como num “falso” ou “pseudodocumentário” ou mockumentary), ele é sempre feito de asserções sobre o mundo, ou ao menos asserções sobre o seu autor. Fernão Ramos afirma que:

\footnotetext{
${ }^{14}$ Utilizo aqui a noção de “mundo vivido” ao invés de “mundo real” ou “mundo histórico” para buscar - mesmo que parcialmente - uma linguagem menos positivista ou naturalista, pois menos carregada por essas tendências.
} 
Documentário é uma representação narrativa que estabelece asserções com imagens e sons, ou com o auxílio de imagens e sons, utilizando-se das formas habituais da linguagem falada ou escrita (a fala da locução, ou a fala dos homens e mulheres no mundo, ou ainda entrevistas e depoimentos), ruídos ou música. As imagens predominantes na narrativa documentária possuem a mediação da câmera, fazendo assim que asserções faladas sejam flexionadas pelo peso do mundo. Essa é a graça e o âmago da fruição espectatorial do documentário, e compõe o núcleo motriz de sua tradição longeva: asserções que trazem ao fundo a intensidade do mundo, de modo dramático, trágico, cômico, poético, íntimo, etc. (RAMOS, 2008, p. 81).

Um filme documentário não é uma reprodução total da realidade, mas é, ele mesmo, sempre uma nova produção que não existia antes de ser produzido. "Indiscutivelmente, o documentário não é reflexo da realidade, mas interpretação, seleção, discurso” (BERNARDET, 2003, p. 278). Desse modo, o documentário é sempre uma novidade, uma interferência no mundo, muitas vezes buscada como uma intervenção planejada em contextos pessoais, sociais, culturais ou históricos. Não é nunca simplesmente ou unicamente a "imagem do povo" que é expressa em documentários, mas sempre a imagem que os realizadores têm do povo, ou de poucos sujeitos, ou de um sujeito, ou de outros seres e objetos, por mais ativos em co-realizar o filme com outros que os cineastas possam ser.

Bill Nichols (2012, p. 135) define seis tipos ou modos de representação do documentário: expositivo, reflexivo, observativo, participativo, poético e performático. Porém atualmente, esses modos do documentário não são mais suficientes (ou nunca foram) para descrever o documentário. As barreiras entre ficção e não-ficção se tornaram menos claras ou mais permeáveis, e uma leva grande de filmes dos anos 1980 e 1990 se utilizaram justamente dessas fronteiras para enriquecer seus trabalhos em termos de alcance e significados. Por conta de ser múltiplo e contraditório, nem realidade unicamente, nem ficção unicamente, o documentário passou a ser entendido também como um “campo":

Portanto, a paisagem documental atual não se ergue num horizonte canônico único, mas numa multiplicidade sem precedentes de formas, certamente como algo que se deixou afetar e abriu passagens por entre 
as tantas ondulações e revoluções da cultura audiovisual contemporânea. Nunca se produziu tantos documentários, nunca se dispôs de tantos suportes e mídias (químicos, eletrônicos, digitais), nunca um regime imagético propiciou tamanha variação estilística. Das formas flaherty-griersonianas revisitadas, do compenetrado Cinema Direto ao perambulante Cinema Verdade, dos filmes de montagem que re-interrogam os arquivos audiovisuais às poéticas experimentais performáticas que sacodem as significações dominantes, o campo do documentário diagrama-se como uma vasta e polifônica rede de produções urdida na correlação de descoberta e invenção, tradição e transformação, referenciado, assim, num tipo de temporalidade bastante diverso do padrão exclusivista moderno (RENOV, 1999, p. 318).

Traçamos esse caminho teórico entre muitas outras categorizações ou identificações, feitas por diversos autores, que podem ser feitas para documentários com base nas suas formas de relação com o Outro representado. Alguns filmes como os de Robert Flaherty ou Jean Rouch fazem do documentário uma apresentação antropológica do Outro, no sentido de visar uma representação do mundo real, mesmo esse mundo sendo produzido especialmente para um filme. Outros filmes "podem representar o mundo da mesma forma como um advogado representa os interesses de um cliente: colocam diante de nós a defesa de um determinado ponto de vista ou uma determinada interpretação das provas” (NICHOLS, 2013, p. 30). Outros se querem didáticos, apresentando um Outro num modelo sociológico como na tradição griersoniana. Outros, ainda, ficam retidos na experiência individual, de um Outro ou do próprio cineasta (que se produz em Outro para o filme). Observamos que nesses modos de representação do documentário e não há uma correlação direta entre a sua categoria do modo, as estratégias e técnicas de produção, e as formas de recepção.

O Outro do documentário não é de um tipo assume uma forma somente e isso tem sido notado nos estudos do documentário, onde nos quais, por vezes, tem essa variedade tem sido usada para categorizado os próprios filmes com base na relação com o Outro. Esse Outro pode ser desde um outro cultural, (pessoas de uma outra cultura diferente daquela dos realizadores do filme,) ou pode ser mesmo alguém muito próximo dos realizadores. O Outro é construído por discursos e várias formas de representação em produções culturais como livros, filmes, fotografias, entre outras, etc. e toda essa gama 
de produções intervêm na recepção das representações fílmicas, preexistem a elas para muitos públicos. Essas formas de representação são muitas vezes parte das práticas de opressão e dominação que mantêm certos grupos na condição de subalternos. Contando como os regimes dominantes de representação, as conexões entre representação e dominação atuam sobre pessoas negras, Stuart Hall diz que esses regimes

\footnotetext{
tinham o poder de nos fazer ver e vivenciar a nós mesmos como “Outro”...Uma coisa é posicionar um sujeito ou grupo de pessoas como o Outro do discurso dominante. É outra coisa bem diferente sujeitá-las àquele "saber," não somente em questão de desejo e dominação impostas, mas pelo poder de compulsão interna e conformação subjetiva à norma (HALL apud HOOKS, 1992, p. 3, tradução nossa).
}

Temos que ter cuidado aqui para não recorrer levianamente a teorias do campo da psicologia, ou seja, atribuir apenas aspectos psicológicos a essa produção do Outro, como se essa produção começasse de dentro da interioridade dos sujeitos, o que nos levaria a uma posição narcísica em relação a esse processo. bell hooks nos lembra que, sem a supremacia branca, não haveria a internalização do racismo. Portanto, não se trata de um processo psicológico interno, e sim de um processo histórico e cultural que opera na construção dos negros como Outro da cultura dominante, que ao construir seu Outro, no mesmo processo constrói seu Eu, que na cultura ocidental dominante é de cor branca. Ela também aponta que há um Outro criado com a representação do "branco" e da "branquitude” no imaginário dos grupos negros, que aprenderam a associar branquitude com terror (HOOKS, 1997, p. 346), e que perceber isso ajuda a descolonizar nossas mentes.

Existem muitos legados de representação do Outro, e na cultura ocidental em particular podemos apontar para alguns destes deles, como o romantismo, o evolucionismo, o orientalismo (SAID, 2003, p. 1). Essas formas estiveram intimamente ligadas a processos de dominação e colonialismo. Porém não serviram apenas para justificar dominação e colonialismo após o fato justificá-los: esses legados da cultura Ocidental foram também impulsionadores das empresas coloniais. Antes da dominação inglesa do século XIX nos continentes asiático e africano, antes mesmo desses serem continentes assim nomeados pela colonização, a cultura vitoriana inglesa, por exemplo, já 
vivia sob a episteme $e^{15}$ da evolução, um dos grandes legados de pensamentos propulsores da colonização, que se julgava benéfica pois o "mais evoluído" - (e aqui as palavras importam menos que as formações do pensamento e do desejo -) teria o direito natural e o dever moral de ajudar os menos favorecidos pela natureza. (FICHMAN, 2002). O evolucionismo vitoriano enquanto teoria(s) é indissociável do colonialismo europeu enquanto prática.

Entre formas de representação dominantes do Outro geralmente encontramos estigmas e estereótipos (HALL, 1997, p. 225; SOARES, 2009, p. 2). Na tradição cinematográfica e documentária, essas formas dominantes de representação também se dão. Com a crítica pós-colonial e pós-estruturalista da subjetividade e da representação desde os anos 1960-70, aos realizadores de documentários têm sido requisitado que conheçam bem os legados históricos e culturais de sua formação como sujeitos do saber, da produção da comunicação e como sujeitos políticos. Não são aceitas mais tão facilmente as asserções objetivistas sobre o mundo, onde o realizador seria neutro ou imparcial. Reconhece-se cada vez mais a parcialidade de qualquer representação, por mais “indexada” (XAVIER, 2012, p. 18) que seja. Ao falar do Outro, estamos falando da “representação da diferença” articulada por Stuart Hall (1997, p. 232, tradução nossa).: "Podemos descrever todo o repertório imagético e de efeitos visuais pelos quais a 'diferença' é representada num dado momento histórico como um regime de representação (...).”

Não podemos, contudo, saber, simplesmente ao ver um filme, quais escolhas foram feitas conscientemente sobre a propagação de supostas verdades sobre um Outro. Nossas representações são sempre parciais e refletem nossas escolhas, que são formadas pela nossa constituição específica dentre de redes sociais de poder, de linguagem, cultura, história, etc. Não há determinismo aqui, embora as escolhas de realizadores sejam feitas dentro dessas redes. Entender a nós mesmos, nossas histórias, culturas, políticas, subjetividades, é então uma condição sine qua non do audiovisual que se quer produzir enquanto um meio para a melhoria da qualidade de vida e para a reconstrução ou a reprodução de nós mesmos.

No Brasil, dentre os filmes que alcançaram as telas de cinema ou televisão nos últimos 15 quinze ou mais anos e que retratam grupos oprimidos, grande parte é de filmes realizados por produtores que não são desses grupos. No entanto, cresce a cada dia a

\footnotetext{
${ }^{15}$ Ver definição na página 5 da Introdução.
} 
produção audiovisual de grupos marginalizados ou excluídos, como moradores de favelas e periferias, por exemplo (POLYDORO, 2011; SILVA, 2011). Tanto realizadores não pertencentes ao grupo que desejam retratar, quanto realizadores a ele pertencentes, se veem na condição de fazer da voz de Outros a voz predominante no documentário. Nesse sentido, a tradição cinematográfica e do filme documentário no país têm no "outro popular” (RAMOS, 2008, p. 205) um dos seus traços representativos marcantes.

Nos anos 1990, por exemplo, o filme documentário brasileiro se voltou, em grande parte de suas produções com distribuição em nível nacional, para a representação do Outro socialmente marginalizado ou criminalizado. Fernão Ramos (2008, p. 207) aponta para duas formas de representação dominantes nesses filmes: o "popular criminalizado” e o “miserabilismo” (RAMOS, 2008, p. 211), ambos ocasionados pela diferença de classe (e podemos dizer também de raça, e por vezes gênero e sexualidade) entre realizadores (a maioria de classe média ou alta) e os Outros representados. Todas essas formas dominantes de representação do Outro têm contextos sociais, culturais e históricos específicos. O que é (re)produzido como representações dominantes por um filme documentário é sempre o resultado dos (des)encontros entre realizadores, sujeitos representados como Outros e os espectadores que trazem suas próprias cargas interpretativas baseadas em seus legados próprios de representação.

O Outro é irredutível às representações que se fazem. Jean-Claude Bernardet (2003) já mostrou, por exemplo, como as representações do outro popular, o “povo”, são historicamente contingentes. Segundo Bernardet, passamos no Brasil por uma história semelhante a outros países, onde o filme documentário deixou de ser dominado por representações sobre o "outro”, nas quais impera um discurso do saber, para produções que dão mais margem a esse "outro" como sujeito de seu próprio discurso. "Para ele, o sucesso da representação de indivíduos das classes populares nos documentários dependeria especialmente de dois fatores: a posse efetiva dos meios de produção e as rupturas na linguagem cinematográfica convencional.” (DE GRANDE, 2004, p. 6). As estratégias nesse sentido têm variado desde a co-realização de filmes, até o peso maior dado a testemunhos. Essa mudança de paradigma é notável, embora ainda assim tenhamos dificuldade em articular as bases - mesmo que frágeis - para filmes documentários que se querem aliados dos Outros. Escreve César Guimarães:

Se para Fernão Ramos um dos problemas mais incômodos no âmbito do documentário brasileiro recente é a “má consciência” do realizador 
(pertencente à classe dos que têm títulos) ao filmar os que pertencem à classe dos não-contados, julgamos que tal dificuldade só pode ser enfrentada se a relação entre quem filma e quem é filmado alcançar, simultaneamente, um processo de subjetivação um ato de individuação. Como afirma Rancière, um processo de subjetivação só pode ocorrer se surge uma tomada de palavra na qual o sujeito se arranca do lugar dos não-contados, de todos aqueles que só tem a phoné [voz], e passa a participar do sensível sob outra modalidade, a do logos [saber, palavra]. Resta identificar, contudo, os recursos expressivos de que o documentário dispõe para dar conta de um processo que tanto o atravessa quanto o ultrapassa (GUIMARAES, apud MIGLIORIN, 2010, p. 185).

Alanis Obomsawin, documentarista indígena do Canadá, diz: “Eu amo o filme documentário porque a voz vem diretamente das pessoas”16. Obomsawin lutava contra a opressão dos povos nativos do Canadá tanto pelo governo do país, quanto pelas formas dominantes de representação desses povos nos filmes de Hollywood. Através de seus filmes, ela acredita ter levado as vozes desses povos aos lugares em que essas não chegariam de outra forma, além de ter lhes dado a palavra. No entanto, como nas questões que são debatidas por muitos, como Fernão Ramos e levantadas por César Guimarães, como podemos avaliar se as vozes de Outros nos filmes documentários são ouvidas como mais que sons, se são ouvidas, de fato, como um outro saber? Essa avaliação é também uma reflexão sobre o mundo vivido que atravessa e que ultrapassa o filme documentário, seu próprio contexto de produção e recepção. Analisar criticamente o documentário como forma de representação do Outros exige, ao mesmo tempo, um foco particular em filmes específicos e uma reflexão contínua sobre as formas de representação em outros campos, tais como a literatura, as ciências humanas e o cinema mais amplamente, para citar alguns. Isso porque as representações sobre Outros em documentários já estão sendo produzidas em grande parte antes dos filmes mesmos o serem: por exemplo, há vários discursos sobre o “louco”, o “delinquente”, entre outros que circulam, e é nesse contexto que filmes são produzidos. Um filme intervém e produz efeitos conforme as respostas que dá às formas de recepção e aos discursos que se ligam a ele muitas vezes antes mesmo dele ser produzido.

\footnotetext{
${ }^{16}$ Retirado de http://blog.nmai.si.edu/main/2013/06/alanis-obomsawin-documenting-native-canada.html.
} 
Todo documentário é um produto sociocultural, e, como tal, reflete relações sociais, culturais, históricas e políticas, assim como as (re)produz, podendo interferir no mundo vivido de formas múltiplas e até contraditórias entre si. Pois os efeitos do documentário no contexto social, cultural e político dependem de suas contingências desses. Considerando essa problemática, essa pesquisa busca entender os meios utilizados e as relações de poder, saber e subjetividade que interferem na produção de documentários que representam Outros particulares. Esses Outros junto aos quais o documentário se engaja são definidos pelo próprio documentário, que em sua "voz" (NICHOLS, 2012, p. 72) por vezes busca, por exemplo, impulsionar a voz de Outros que se encontram “subalternizados” (SPIVAK, 1988, p. 273), marginalizados ou oprimidos. Essa voz do Outro subalterno, como mostrou Spivak (1988, p. 273), é sempre construída, isto é, porta uma novidade que é o filme, portanto muitos projetos falham ao querer representar vozes de Outros justamente por não atentar para essa construção. Nessa perspectiva, muitos documentaristas querem representar as vozes de Outros como aliados que buscam ser (entre outras possibilidades) ${ }^{17}$, mas ao atuarem podem estar fazendo exatamente o contrário: reproduzindo opressões ou silenciamentos.

Homi Bhabha, um importante pensador pós-colonial, utiliza o conceito de hibridismo para descrever a presença de um espaço de alteridade dentro do processo cultural. Embora ele centre sua atenção na colonização especificamente, hibridismo é a diferença sempre presente em qualquer produção cultural. Para o autor, a resistência à opressão não pode ser reduzida a um ato de oposição de intenção política. O hibridismo está sempre já presente em qualquer forma de relação de dominação que envolva discursos e práticas culturais. É assim que a modificação e a multiplicidade de discursos e práticas culturais sempre está operante, inclusive pelas ausências e silêncios. Não há possibilidade de um discurso, por exemplo, ser fixado de uma vez por todas, para além de todas as novas representações e interpretações. Os discursos sobre um Outro não podem ser fixados para sempre. Como afirma Bhabha afirma, o significado nunca é simplesmente mimético e transparente, existe o "Terceiro Espaço da enunciação" (BHABHA, 1994, p. 37). Portanto, deve-se esperar que qualquer discurso de libertação pode também - e, de fato, devemos esperar que irá - oprimir. Para o autor, qualquer ato de interpretação é ambíguo, pois a cultura é um híbrido, há sempre um “no meio” da cultura, iludindo a "política de polaridade" (BHABHA, 1994, p. 37). Assim, em seu

\footnotetext{
${ }^{17}$ Há sempre a possibilidade de se representar vozes que são consideradas inimigas dos realizadores do documentário.
} 
entendimento, qualquer representação é repleta de incertezas, trocas desiguais, diferenciais de poder, e significantes que significam coisas muito diferentes para pessoas diferentes, particularmente dentro de diferenças de cultura, história e relações sociais e políticas. Na história do colonialismo, se por um lado a ideia do Homem universal foi parte integrante da instituição de poderes coloniais, por outro gerou resistências a esse mesmo paradigma ocidental de entendimento e organização do mundo. Como diz Bhabha (2001, p. 72):

\begin{abstract}
A luta contra a opressão colonial não apenas muda a direção da história ocidental, mas também contesta sua ideia historicista de tempo como um todo progressivo e ordenado. A análise da despersonalização colonial não somente aliena a ideia iluminista do "Homem", mas contesta também a transparência da realidade social como imagem prédada do conhecimento humano.
\end{abstract}

Assim como Bhabha, Gayatri Spivak faz críticas contundentes a tentativas essencialistas de representação. Não só apenas por conta de serem construções falidas, mas muito mais do que isso, pois o "essencialismo” é um dos instrumentos de poder de relações desiguais. Ao enquadrar sujeitos em categorias fixas, o discurso essencialista cria o campo do que pode ser e do que não pode ser para o sujeito. O sujeito construído como essência é sujeito (no sentido de sujeição) à dominação e à opressão. Spivak não é contra a utilização do essencialismo, no entanto. Ela fala, inclusive, na possibilidade do "essencialismo estratégico": quando se faz uso de representações essencialistas como escolha politizada para a promoção da resistência à opressão. Ou seja, para Spivak os efeitos da representação no mundo são mais importantes do que a questão de utilizar ou não o essencialismo. A questão não é decidir qual a representação correta do Outro, mas sim avaliar quais os efeitos de representações específicas no mundo vivido. Outras pensadoras feministas têm nos desafiado a sermos baseados nos efeitos (sociais, culturais e políticos) e não baseados no conhecimento (HOOKS, 1992). Essa preocupação maior com os efeitos de uma produção do que sobre uma suposta representação final e isenta de relações de dominação, é característica também de Michel Foucault e Jacques Derrida.

Derrida é um autor importante para nossa pesquisa, apesar de seus escritos versarem muito mais sobre textos, em sentido amplo, do que sobre outras formas de representar. Mas se utilizarmos as ideias dele sobre textos para produtos audiovisuais, 
temos como resultado um grande impacto nas formas de pensar dominantes sobre o ato de representar audiovisualmente. Isso porque, como são sempre relacionais, tanto os textos audiovisuais quanto textos verbais dependem de contextos sociais, políticos e culturais de interpretação, utilização e fixação de significados. Os documentários são desde sempre socioculturais e sempre reproduzem o contexto de sua formação, em muitos aspectos, em suas problemáticas. Portanto, com Derrida, o que podemos esperar de um documentário que faz críticas, é que ele reproduza justamente o que critica, de alguma forma. Podemos também esperar que um documentário possa ir além disso e provocar fugas e saídas (mesmo que parciais) para os problemas que ele apresenta. Spivak faz uma crítica que foi elaborada por Edward Said em relação ao trabalho de Michel Foucault sobre o poder, colocando que o intelectual não pode se esquivar de sua “responsabilidade intelectual” (SPIVAK, 1994, p. 75). O intelectual, como um ser no mundo, não tem escolha sobre tomar ou não tomar parte na representação, nas relações de poder, em suma, em quem pode ou não pode ter voz ou vez. Com Derrida, temos a impossibilidade de qualquer representação se dizer final, pois há sempre uma multivocalidade presente, uma impossibilidade de um processo que busca representar Outros e o mundo ser fechado e final em si mesmo. .

Michel Foucault nos mostra em diversos trabalhos, entre eles como Vigiar e Punir (1975), e nos volumes de História da Sexualidade (1976), por exemplo, como sujeitos são efeitos de discursos, não somente seus produtores. Em seus estudos, discursos são o acoplamento das relações de poder com o saber, ambos historicamente contingentes e relacionados. Todo sujeito joga com e compreende eventos através de formas de representação que são sempre culturalmente, historicamente, politicamente múltiplas, ainda que os sujeitos não possam ser. O sujeito não pode ser totalmente consciente das formas de representação com as quais está lidando. Foucault chegou a trabalhar em três eixos: verdade, poder e subjetividade. Para ele, a triangulação entre produção de verdade, produção de subjetividade e produção de relações de dominância e resistência (as quais sempre coexistem), é o eixo para discutir como se constroem "sujeitos falantes.”. O sujeito pode ser, aqui inclusive, a voz no/do documentário.

Foucault propõe um conceito ampliado de discurso, fazendo-nos olhar para aquela triangulação como central para a compreensão das operações de sistemas de saber e de poder. Para funcionar, discursos precisam de sujeitos que operam de certas maneiras e não de outras. A dominância de certas verdades que circulam como tal está, então, intimamente ligada à produção de sujeitos (nos dois sentidos da palavra, como sujeitos de 
ação e assujeitados), quanto a instituições e hábitos que não são verbalizados, assim como um filme não fala diretamente para nós sobre sua produção. Para Foucault, mesmo os discursos que parecem mais libertadores, como o da liberdade, numa certa conjunção institucional e de produção de sujeitos, podem ser justamente a prática do retorno da opressão (FOUCAULT, 1977, p. 150). Ele não se preocupa, portanto, com a verdade de produções culturais tanto quanto se preocupa com seus efeitos sobre as possibilidades do saber, do poder e da subjetividade. A verdade é, para Foucault, uma produção, realizada entre relações de linguagem e poder, portanto sempre situada e sempre relacional. Falando sobre suas investigações, ele diz:

Não estamos portanto buscando descobrir o que é verdadeiro ou falso, fundado ou infundado, real ou ilusório, científico ou ideológico, legítimo ou abusivo. O que estamos tentando descobrir é quais são as ligações, quais as conexões que podem ser identificadas entre mecanismos de coerção e elementos do saber, qual é a interação de retransmissão e apoio desenvolvidos entre eles, de tal modo que um dado elemento do saber toma para si os efeitos do poder num dado sistema onde é alocado a um elemento verdadeiro, provável, incerto, de tal modo que um procedimento de coerção adquira a forma própria e justificativas de um elemento racional, calculado, tecnicamente eficiente etc. (FOUCAULT, 2007, p. 59, tradução nossa).

Para Foucault, o que ele chama de discurso, verdade, ou poder é sempre um campo instável de relações onde coerções coexistem com resistências, e tanto a coerção quanto os elementos de conhecimento e saber não precisam ser conscientes ao indivíduo para que este possa agir. Pelo contrário, Foucault aponta para o modo como sujeitos, saberes e poderes são inconscientes culturais herdados que vão sendo retrabalhados a todo instante, ao mesmo tempo em que são instituições e materialidades. O máximo que podemos fazer, dado que somos todos parte de inconscientes culturais, é tentar ver o claro no escuro, e mesmo assim, podemos nos enganar quanto ao que é o claro ou escuro, dado o claro/escuro da cultura e época em que vivemos e instituições e materialidades que nos formam e cercam.

Ismail Xavier mostrou como o cinema opera num campo maior que ele mesmo, que é o do "discurso cinematográfico” (XAVIER, 2012, p. 165). Para Ismail Xavier, o cinema é - também -- um discurso, o que implica que há muito que não se revela muito 
diretamente, ficando num nível mais inconsciente ou interpretativo no trabalho que se faz com imagens e sons pelo cinema. Para fazer uma crítica do discurso cinematográfico de um filme, é necessário, primeiramente, buscar compreender a quê esse discurso está relacionado, seja nas artes, seja na vida social, cultural e histórica. Para Xavier, nossos métodos de análise de filmes são desde sempre influenciados pelos filmes mesmos. Não há uma crítica objetivista de filmes, na qual seria possível, por exemplo, se utilizar de dicotomias como representação/desconstrução ou realismo/vanguarda para catalogar filmes.

Os discursos dominantes sobre o cinema num dado momento têm como resultado a prática de hierarquizar filmes, colocando alguns como mais “modernos” do que outros. Assim, muitos estudos, assim como os próprios filmes, são o resultado de respostas reativas ao cinema dominante de uma época. Deste modo, a análise crítica tem que entender que conceitos e discursos operam no entorno e por meio dos filmes, mas precisa ir muito além disso. Escreve Ismail Xavier:

Dentro de uma perspectiva mais consequente, creio ser fundamental não apenas considerar o que uma proposta rejeita, mas também o que ela incisiva ou veladamente afirma. E, principalmente no que se refere a propostas recobertas por conceitos como vanguarda, realismo ou desconstrução, a tarefa fundamental do analista é a interrogação pelo que de particular tal realismo, tal vanguarda ou tal desconstrução apresenta. Tais etiquetas, via de regra, consistem na instância inicial de um debate; aquelas noções por onde a discussão começa e não a referência definitiva por onde a discussão termina.” (XAVIER, 2012, p. 166).

Ismail Xavier, assim como Bill Nichols (1994, p. 42) e Paula Rabinowitz colocam que a compreensão do audiovisual é um ato intrínseco de interferência no meio sociocultural. Com estes autores aprendemos que nunca escapamos de valorar, não há análise neutra do audiovisual. Escreve Rabinowitz: "Precisamos estar atentos a como são importantes a representação e a referência histórica um para o outro e para as relações de poder e saber” (RABINOWITZ, 1994, p. 214, tradução nossa). Nenhuma representação, mesmo aquela realizada por analistas críticos, ocorre num vácuo de poder. Falar e escrever sobre produções culturais como filmes, é sempre um ato político no sentido da prática da transformação social ou da manutenção do status quo, ou, o que é mais certo, um pouco dos dois. Bill Nichols cunhou um tipo de análise crítica de filmes que tem um caráter dual, chamada por ele de “análise formal-social”, desenvolvida no seu livro Engaging Cinema (NICHOLS, 2010). Nesse livro, o autor mostra como um filme pode 
sempre ser analisado tanto em seus aspectos de forma, sua utilização e tratamento de imagens e sons, sua narrativa, montagem, etc. - como em seus aspectos sociais -, como responde a questões de identidades e diferenças, questões históricas, socioculturais e políticas de seu tempo. Pois é certo que todos os filmes são produzidos dentro de contextos socioculturais e depois circulam produzindo efeitos em sujeitos formados de maneiras que determinam em parte como os mesmos filmes são recebidos. Filmes são seres que têm vida, circulam produzindo efeitos em outras vidas.

Edward Said cunhou o termo "mundanidade” (SAID, 2007, p. 84), referindo-se a uma maneira de fazer a crítica de textos enquanto linguagem social. O conceito nos serve para a pesquisa, pois filmes são representações, linguagens. O termo “mundanidade” (worldliness) surgiu tanto das análises culturais de Said, quanto da experiência dele como Palestino e exilado, e é sua resposta de Said ao pós-estruturalismo dos anos 1970, que ele admirava mas que, para ele, era pouco politizado pelo "mundo" fora dos textos teóricos e da academia, ou mesmo frente a desafios sociais e políticos colocados desde os anos 1960. É uma crítica da especialização excessiva que impõe uma linguagem inacessível e cria dogmas culturais, o que faz com que, muitas vezes, a academia acabe falando somente consigo mesma. O crítico mundano, para Said, precisa ser “amador” no que faz. Uma crítica mundana considera, simultaneamente, tanto os aspectos formais quanto sociais de um filme, simultaneamente.

Críticos de Said lhe perguntaram como é que povos colonizados poderiam ser entendidos fora dos processos de representação. Para Said, no entanto, a realidade é uma característica da textualidade em si, da mundanidade da linguagem, e a questão não é tanto a de uma representação dominante esconder a realidade, mas sim a luta entre representações diferentes e contestadoras entre si, que é também uma disputa entre discursos. Ele mostra como a crítica literária contemporânea valoriza sobremaneira as “operações formais do texto, mas muito pouco a sua materialidade.” (SAID, 1983, p. 148). Aqui, arriscamos dizer que o mesmo se dá em relação à crítica cinematográfica contemporânea, em que vemos as análises formais e técnicas de filmes terem primazia sobre análises socioculturais. Os motivos me parecem ser os mesmos colocados por Said, central entre eles o do academicismo exacerbado ao ponto das análises que se dizem críticas se perderem em aspectos formais em detrimento dos sociais, que ajudariam inclusive a compreender melhor as direções formais tomadas pelos filmes. 
Said constrói o conceito de “mundanidade” em relação ao estruturalismo, em que o texto não precisa de um Autor, como em Roland Barthes ${ }^{18}$, e ao pós-estruturalismo, em que o texto não tem um significado central, como em Derrida. Ambos retiravam a relação direta do texto com o mundo, com as relações de poder. Para Said, “o texto é produzido pelo mundo, um concerto das forças materiais de poder neste mundo, e a contextualidade/localidade de que fala especificamente” (ASHCROFT, 1999, p. 24). Ele elabora seu conceito de Afiliação/Filiação de textos: "Recriar a rede de afiliação é, portanto, tornar visível, dar materialidade de volta, aos fios que prendem o texto à sociedade, autor e cultura” (SAID, 1983, p. 175). O crítico mundano precisa ser “amador” no que faz.

A linguagem tecnocrata/especialista silencia sobre questões de opressão e resistência. O crítico, como um ser do mundo, não tem opção senão reproduzir de alguma forma esse mundo, nem que seja pela negação, ou mesmo que inconscientemente. O crítico está inserido na crítica que faz, tem responsabilidade pela leitura, mesmo que parcial: “A crítica é, portanto, não uma ciência, mas um ato de engajamento político e social que é por vezes paradoxal, por vezes contraditório, mas que jamais se solidifica em certeza dogmática”. A tarefa do crítico seria humanista:, “falar da verdade ao poder”, e nisso Said faz uma leitura em contrapontos: rejeita a univocalidade, mas deixa aberta a possibilidade de que uma voz seja produzida, e que esta tenha materialidade e efeitos pretendidos.

Na sua suspeita de conceitos totalizadores, em seu descontentamento com objetos reificados, em sua impaciência com alianças, interesses especiais, feudos imperializados e hábitos ortodoxos da mente, a crítica é mais ela mesma e, se o paradoxo pode ser tolerado, menos ela mesma no momento em que começa a se transformar em dogma. (SAID, 1983, p. 29).

A crítica, numa palavra, não pode silenciar.

\footnotetext{
${ }^{18}$ No texto “O que é um Autor?” (1998), Michel Foucault mostra como o conceito de Autor é um discurso - no sentido que não segue regras da lógica ou gramática, mas surge por outras relações com os "autores”, suas relações institucionais, o status de seus trabalhos numa dada cultura. A própria desconsideração do Autor em nome do Texto, portanto, como faz o estruturalismo, é resultado de operações discursivas e institucionais.
} 


\subsection{Caminhando do Outro para o documentário como portador de uma voz}

Se, como vimos até aqui, toda representação sobre um Outro é sempre carregada de história, subjetividade e cultura, é múltipla e contraditória; se o documentário mesmo é múltiplo em suas formas de representação e suas possibilidades, fronteiras e usos; então analisar o filme documentário enquanto objeto é tratar de um objeto já múltiplo, já contraditório, já não-apenas-objeto pois quase-sujeito a muitos Outros além dele. A história do documentário que traçamos aqui, longe de ser única e unívoca, é uma linha traçada que nos mostra que houve sempre, desde os primeiros filmes, uma preocupação com as técnicas e estratégias de representação. Para além do documentário, discorremos sobre como os legados de representação e suas relações com culturas e poderes dominantes afeta qualquer relação com Outros representados.

Se na história do documentário sempre houve essa preocupação com as formas de representação de Outros, por outro lado essa é uma preocupação que vai muito além do processo de produção ou recepção de filmes. A representação do Outro é o grande campo dentro do qual escolhemos aqui pensar o filme documentário (e dizemos aqui filme com o propósito de enfoque teórico). Nossa indagação ao filme documentário é sobre o quanto ele é capaz de ser aliado de seus Outros representados, seus sujeitos filmados. Nossa elaboração teórica está centrada até aqui o Outro representado em filmes documentais onde a esse Outro ao menos foi concedida uma representação não-afrontosa ou conflitiva e se buscou utilizar do filme como um instrumento de afirmação do Outro em sua diferença. Pelo momento, deixaremos um pouco a questão do Outro, para adentrar na questão do filme documentário como um Sujeito/Objeto ele mesmo, que ao ser posto no mundo, circula, produz efeitos, cria possibilidades enquanto desafia ou inibe outras. 


\section{CAPITULO 2}

\section{A voz mútlipla do documentário}

\subsection{A Voz de Deus}

A Voz de Deus. Com esse termo, foram categorizadas muitas narrações em filmes documentários, embora esse seja apenas um conceito criado que não tem definições ou delimitações rígidas. Ele define documentários em que há a voz de uma pessoa que narra o filme, sendo sobreposta às imagens e outras faixas de áudio. Trata-se de um lugar para a narração conhecido como voice-over, em que o narrador nunca aparece em cena, nem comunica nada sobre sua subjetividade. "Desencorporada, essa voz é construída como fundamentalmente irrepresentável em forma humana, conotando uma posição de absoluto domínio e conhecimento fora das fronteiras espaciais e temporais do mundo social que o filme retrata” (WOLFE, 1997, p. 149, tradução nossa). Esse foi o legado de uma parte significativa dos documentários dos anos 1930 e 1940. Esse mesmo legado serviu de ponte para o que veio depois, nos anos 1950 e 1960, com o Cinema Direto, Cinema Verdade e outros legados de filmes que optaram por não terem narração ou por usarem apenas som ambiente ou direto. E muitas vezes essa opção por não utilizar narração foi uma resposta direta ao legado da Voz de Deus. Em documentários contemporâneos, o uso da narração deixou de ser dominantemente impessoal para se tornar em grande parte pessoal, seguindo a tendência da inserção da subjetividade dos cineastas ou dos sujeitos filmados. Essa mesma valoração existente hoje para os documentários mais subjetivos, pode ser entendida no contexto da rejeição, de um grande “Não!” à Voz de Deus como legado formal do documentário. O perigo da construção de um comentário unívoco e quasi-onisciente assombra, até hoje, muitos documentaristas quando realizam seus filmes. Todo comentário unívoco dentro de filmes evoca a lembrança do legado da Voz de Deus no documentário e muitos documentaristas justamente por buscarem se afastar dela, acabam por moldar seus trabalhos em resposta a esse legado. Desde os anos 1960 pelo menos,

O impulso dos críticos vèritè a rejeitar comentários vocais no documentário como não simplesmente autoritativa mas autoritária, e desse modo a resistí-la, carrega consigo a suposição de que vozes 
sobrepostas a imagens e sons gravados são de algum modo destacáveis do documento fílmico autêntico. Preconceito contra as ambições imoderadas de uma 'sobre-voz' podem desse modo revelar uma fé nãodita na autenticidade de imagens e sons "não-narrados”, repositórios de uma verdade que pode ser discernida sem as interrupções ou interferência de um intérprete invisível (WOLFE, 1997, p. 151, tradução nossa).

Nem tudo é a Voz de Deus, no entanto, quando se fala em narração ou comentário no documentário, mesmo quando essa narração é feita em off. Como pontuamos inicialmente, trata-se de um termo genérico e não há consenso sobre seus limites. Porém, ele é sim útil pois podemos considerar que ele já faz parte do léxico de documentaristas e, quando colocado, todos esses profissionais têm alguma ideia do que se está a dizer. Para muitos, é algo a evitar, e isso acaba por ter o efeito prático de delimitar os recursos a utilizar. Para outros, talvez não ainda apresentados ao termo e às críticas sobre os discursos autoritativos, as problemáticas de representação trazidas à tona pelo uso desse tipo de narração talvez ainda não tenha chegado aos olhos. Os cineastas escolarizados, no entanto, têm no geral uma opinião formada sobre a Voz de Deus e sobre o quanto essa herança é problemática quando utilizada sem critérios, sem responsabilidade e de maneira inconsequente. Essa grande rejeição ao comentário em voice-over, no entanto, pode ser ainda um resíduo da mesma vontade de verdade, de mostrar as "coisas como elas são”, como aponta Wolfe. A teórica feminista Mary Ann Doane observa que

Entretanto, no documentário, a voice-over passou a representar uma autoridade e uma agressividade que já não podem ser mantidas - assim, como diz Bonitzer, a proliferação de novos documentários que rejeitam o absolutismo da voz over e dizem estabelecer um sistema democrático "permitindo ao assunto falar por si mesmo". E mais, o que este tipo de filme realmente promove é a ilusão de que a realidade fala, ao contrário de ser falada, e que o filme não é um discurso construído. Efetuando uma "impressão de conhecimento", um conhecimento que é dado e não produzido, o filme oculta seu próprio trabalho e coloca a si mesmo como uma voz sem sujeito. A voz é ainda mais poderosa em silêncio. A solução então não é banir a voz, mas construir outras políticas (DOANE, 1983, p. 471, tradução nossa). 
A crítica que podemos fazer em relação ao modo autoritativo do uso do voiceover, é aquela baseada em aspectos da narrativa ou comentário do fílmico unívoco que opera de modo a ocultar seus "lugares de fala”, como se falasse "apenas" a "verdade”. Como Doane aponta nesse sentido, a questão não seria usar do silêncio - pois este pode apenas estar ainda reproduzindo os discursos dominantes - mas, sim, criar discursos a partir de outras políticas, nas quais caibam outras vozes, particularmente as mais oprimidas. Acreditamos que sem os recursos técnicos e poderes para se colocarem, são silenciadas. Djamila Ribeiro, em seu livro O que é Lugar de Fala, mostra que cada sujeito ocupa posições distintas dentro das dinâmicas das relações de opressão e resistência, que tanto possibilitam quanto limitam suas experiências de mundo. Como resultado, tais posicionamentos lhe dão mais ou menos vivência direta das formas de opressão presentes numa sociedade. Uma pessoa branca, rica, nunca sofre o mesmo sentido de opressão que uma pessoa negra e pobre no Brasil, seja pela presença do racismo estrutural em termos das oportunidades oferecidas, seja pelo racismo de atitude em termos de como as pessoas são tratadas diferencialmente. Desse modo, ao falar de racismo, a pessoa branca e a negra falam de lugares diferentes, a pessoa negra da vivência direta dos efeitos e dos limites criados pelo racismo, e a pessoa branca quando não é privilegiada e alienada com relação a questões raciais no Brasil, consegue no máximo falar do racismo enquanto alguém que se preocupa com o Outro. Nesse sentido, o papel da pessoa branca, e sua fala, pode no máximo ser o lugar de fala de uma pessoa Aliada, e não pode ser ela a definir o que é ou não racismo quando este é vivenciado por uma pessoa negra, pois a pessoa branca não tem a vivência corporificada do racismo para entender de dentro como ele se apresenta. O lugar de fala do Aliado, no entanto, é fundamental, e embora observemos a necessidade de dar primazia, estando nessa posição, à escuta do Outro que é alvo do racismo, no Brasil temos ainda um longo caminho a percorrer para entender como podemos ser Aliados. Um Aliado nunca presume uma universalidade da realidade nem do discurso, pois isso seria como falar pelo Outro.

Em meu primeiro filme, Wai'á e o Mundo Xavante (2000), utilizei, quase que inadvertidamente, da construção de uma narração ao estilo Voz de Deus. Eu ainda não conhecia o conceito, e, na época, aos meus 23 anos, acreditava que tinha algo universal a dizer sobre culturas indígenas. Essa noção estava muito em sintonia com uma certa antropologia colonial e também com a psicologia do inconsciente, especialmente baseada na obra de Carl Jung. Em contato com suas teorias, entendi que, assim como Jung, eu tinha sido socializado numa cultura ocidental com um legado de pensamento dominante, 
a metafísica. Porém eu não nomeava meu pensamento como metafísico, ou se o fizesse acreditaria na época ser a metafísica a Verdade. Eu acreditava que a cultura dominante deveria ser repensada, pois tinha se distanciado da natureza. Acreditava numa Verdade universal, mas que essa tinha sido perdida, e que o mundo teria que se reencontrar com ela, realinhando-se ao Natural como Verdade. Como resultado de minha socialização, acreditava que mudanças aconteciam primeiro na consciência e, depois, somente depois, no nível das ações, instituições e materialidades. Pensava eu que primeiro vinham as ideias, depois as ações no mundo (e com isso não quero dizer que o contrário é a verdade). A ideia e a consciência estavam na origem da história. Desse modo, se eu conseguisse mostrar que a Verdade era de que todos fazemos parte do Uno, do Universal que é Unívoco, a Natureza, tudo se resolveria - como num passe de mágica. Como se me inspirasse no modo de Jean-Jacques Rousseau, havia em mim a crença de que o passado da humanidade - algo a ser encontrado em uma cultura particular muito diferente da minha e mais original, segundo meu pensamento na época - esse passado da Humanidade estaria acessível e disponível para ser utilizado como recondução ao caminho do Certo e do Bem. Claramente, a cultura do platonismo e suas releituras pelo cristianismo fizeram parte da minha criação, tudo muito parte da metafísica enquanto formação cultural. Esses eram os legados dominantes de pensamento onde nasci (cidade de São Paulo, Brasil). Esse legado se fez ainda mais forte pelo fato de eu ter crescido em meio aos privilégios dos homens brancos numa sociedade dominantemente racista. Porém, não sei muito bem por que motivo, eu também cresci com um olhar para as injustiças, para as desigualdades raciais, econômicas, de gênero ou outras. Nasci no seio da ditadura no Brasil, numa família onde se criticava essa mesma ditadura e se almejava mais liberdade para todxs. Se por um lado fui educado para buscar a Verdade e fazer o Bem, por outro não percebia o quanto esses conceitos são construções historicamente situadas, daí que ao fazer meu primeiro filme, reproduzi as ideias de Verdade e do Universal, sem refletir sobre por quê o fazia. Eu realmente queria encontrar a Verdade Universal e achava que isso seria não só a minha, mas talvez a libertação do Mundo. Ninguém tinha me ensinado que acreditar na Salvação - como em “A Salvação”, no singular - é um legado histórico que traz consigo toda uma carga de reprodução de formas de opressão.

A socialização na cultura metafísica me fazia muito mal. Mal porque eu realmente me sentia assim por mim e pelo mundo. Tinha problemas psicológicos e físicos por conta disso. Tinha problemas em me relacionar com leveza, pois tudo parecia pesado demais para carregar. Carregar o mundo nas costas, era isso que a cultura dominante me pedia. 
Eu o fazia sem o saber. Pois acreditava que a Verdade era necessária e que era pesada, eu carregava o Mundo nas costas e acreditava que esse era meu caminho.

Fui então buscar a Verdade em outra cultura particular, que na época acreditava mais original que a minha, mais verdadeira. Tive a oportunidade de conviver com o povo Xavante no centro-oeste do Brasil. Tal povo deixava meus dias mais leves enquanto convivia com eles, eram, ao mesmo tempo para mim, uma chave para a Verdade. Mas essa Verdade, sobre a qual colocava tanto peso, não vinha como fardo do povo Xavante. Vinha como fardo que eu levava, buscando me entender como pessoa e entender o mundo. Só que essa busca foi dada por uma parte de minha cultura que me pedia - e pede ainda a todo momento - a Verdade do Eu, do Ser, do Mundo, e de qualquer Objeto ou Outro, como se houvesse uma história final das coisas.

Só fui me dar conta dessa busca pela Verdade que tinha sido inculcada em mim após ter a oportunidade de estudar antropologia pós-colonial num mestrado, onde esse fardo metafísico pôde finalmente deixar-me ao menos em parte. Pois como ensina Jacques Derrida (1978), no momento em que acreditamos estar livres da metafísica, ela pode estar ali com mais força, pois a busca de pureza é busca da Presença, da Verdade sobre si ou sobre o Outro. Acreditar-se livre da metafísica pode ser o retorno dela. O meu primeiro filme, gosto de dizer que marcou uma época da minha vida que logo depois alguns meses depois - não era mais a mesma. Se eu tinha buscado num Outro uma Verdade salvadora, alguns meses depois no ano 2001 eu não era mais o mesmo. Tinha aprendido que as verdades são todas problemáticas e contraditórias, que representar o Outro é um perigo, e que o fechamento de uma verdade ou verdades sobre um Outro, como inevitavelmente acontece quando se fecha ou finaliza um filme sobre Outros, é de uma responsabilidade grande, pois como antropólogos e cineastas sempre intervimos com nossas bagagens históricas nesses fechamentos que recaem com seus efeitos sobre esses mesmos Outros. No entanto, ter feito meu primeiro filme logo antes de me especializar em antropologia, disciplina em que um dos principais campos de estudo é justamente as formas de representação de Outros, me deu sem dúvida alguma bagagem para entender porque vários cientistas sociais estavam levantando as problemáticas da representação. A toda representação que diz “dar voz ao outro”, logo me recordo do que Foucault (1983, p. 231-232, tradução nossa) afirma:

Meu ponto não é que tudo é ruim, mas que tudo é perigoso, o que não é exatamente o mesmo que ruim. Se tudo é perigoso, então sempre temos 
algo a fazer. Portanto, minha posição não leva à apatia, mas a um ativismo hiperativo e pessimista. Eu acho que a escolha ético-política que temos que fazer todos os dias é determinar qual é o principal perigo.

O perigo, para documentaristas que buscam representar Outros, é representá-los de forma que o efeito seja uma piora nas condições de vida desses Outros. Abandonar a narração em voice-over, autoritativa, em favor de formas de representação subjetivistas é uma maneira reativa e metafísica de proceder. Pois acreditar na Verdade da subjetividade - mesmo se se coloca a Verdade como apenas subjetiva, relativa, é continuar na crença da Verdade. Talvez o que venha a piorar a vida desses Outros, seja justamente relativizar sua representação. Talvez em dado contexto uma representação autoritativa seja mais eficaz na defesa do modo de vida de um Outro. Talvez. Pois um mesmo filme pode ter efeitos múltiplos e contraditórios. Como diz Foucault, temos como responsabilidade buscar definir qual é o principal perigo, sem acreditar que encontramos a saída sem problemáticas, pois tudo é perigoso. A questão da representação do Outro deve ser pensada em relação à "mundanidade” do filme e do Outro, no modo como relações culturais e políticas os atravessam, pois os efeitos da representação recaem sobre as vidas dos Outros sujeitos filmados, quer queiramos ou não. Temos que deixar de pensar na Verdade como definidora da representação, para pensar nos efeitos de verdade e práticas sociais que os filmes produzem e reproduzem nas vidas dos Outros sujeitos filmados. Ninguém dá voz a ninguém. Mas filmes podem produzir, reproduzir ou silenciar discursos e práticas das pessoas representadas.

A voz do documentário é um conceito colocado por Bill Nichols em seu livro Introdução ao Documentário, lançado em 2001, e que apresenta a ideia de que todo filme documentário tem uma voz. Seu entendimento sobre tal voz está ligado aos 6 "modos de representação" do documentário que descreve, sendo eles: poético, expositivo, participativo, observativo, reflexivo e performático (NICHOLS, 2012, p. 135). O autor afirma que todos os documentários fazem uso de ao menos um desses modos ou de alguns ao mesmo tempo. Esses modos de representação do documentário, no entendimento de Nichols, são meios pelos quais os documentaristas encontram uma voz que preencha suas necessidades como cineastas. Desse modo, a voz do documentário seria definida pelo cineasta enquanto produz, relativa a esse contexto de produção do documentarista que visa dizer algo a um público. A voz do documentário seria, para Nichols, essencialmente uma voz buscada pelos cineastas que encontram "técnicas 
cinemáticas que funcionam para eles para falar sobre a realidade. Então sentimos que estão falando para nós sobre uma realidade comum."19 Essa voz, para Nichols, é produzida pelo cineasta não somente com vozes de Outros sujeitos filmados, mas também com imagens, sons e músicas. Ele afirma que os primeiros documentários, entre eles os filmes de Dziga Vertov e outros filmes conhecidos como "sinfonias da cidade", como o filme Berlin: Sinfonia de Uma Metrópole (Direção Walther Ruttmann, 1927), - e podemos pensar em outros como Nada Além das Horas (Direção Alberto Cavalcanti, 1926) -, eram filmes que “falavam” apesar de não incluírem falas de pessoas. Nichols caracteriza os filmes silenciosos dos anos 1920 como já tendo uma voz, pois há mensagens passadas pela via das imagens e pela música escolhida, da montagem, ritmo, etc. A partir do final dos anos 1920, entra em cena o legado da Voz de Deus, momento em que a narração passa a fazer parte dos documentários. Mas Nichols lembra que esse é apenas um dos meios cinemáticos usados na produção da voz do documentário e deve ser considerado junto a outros dispositivos de som e imagem. A Voz de Deus não fala sozinha nos filmes, ela é parte de um conjunto cinemático a produzir um tipo de voz do documentário específico a cada filme.

Nos anos 1960, o Cinema Direto e o Cinema Verdade trazem o som direto como um dos principais dispositivos dos filmes, nos quais o que acontece à frente da câmera é frequentemente espontâneo e não planejado. Quando isso acontece, segundo Nichols, uma nova voz é possível aos documentaristas, que podem mostrar o mundo de novas formas, mais parecidas com o tempo dos movimentos e da experiência cotidiana. Nessa perspectiva, os filmes frequentemente trazem sequências contínuas sem cortes, oferecendo ao espectador uma experiência de um tempo mais próximo do que seria aquele dos gestos, pausas, silêncios e movimentos de pessoas. Nos documentários, a voz pessoal do documentarista, inclusive sua presença na cena como personagem do filme, tornou-se, assim, possível. Mais contemporaneamente, a utilização de todos os meios possíveis, incluindo efeitos especiais, animação, momentos de filmes ficcionais ou experimentais, levam a uma proximidade com a ficção e dão riqueza de interpretações via esse uso de dispositivos, técnicas e estratégias variadas (NICHOLS, 2016, pp. 62-68). A voz do documentário pode incluir, por exemplo, uma certa produção de distância entre o que um Outro sujeito filmado diz ou faz, e o que o filme pode buscar afirmar ou deixar em aberto para o espectador decidir por si mesmo. A voz do documentário não aparece

\footnotetext{
${ }^{19}$ Vídeo do Youtube: https://www.youtube.com/watch?v=ROlx1b3q3Dc.
} 
apenas de forma unívoca: pode muito pelo contrário apresentar dissenso entre sujeitos, ou entre os sujeitos filmados e o cineasta, ou ainda usar de dispositivos cinemáticos para colocar em dúvida ou em questionamento aquilo que vemos e ouvimos no filme. Uma multiplicidade de representações e perspectivas cabe na voz do documentário.

A Voz do documentário existe para falar de um mundo compartilhado entre cineasta e público, pois na concepção de Nichols, documentários “falam” desse mundo vivido e compartilhado entre cineastas e públicos. O autor entende a voz do documentário como sendo fundamentalmente definida pelo cineasta, que trabalha sobre os sujeitos e objetos filmados. Porém, é importante notar que a ênfase do conceito está na construção dessa $v o z$ pelos cineastas (e não necessariamente pelos Outros sujeitos filmados). Afirma ele:

os documentários representam o mundo histórico ao moldar o registro fotográfico de algum aspecto do mundo de uma perspectiva ou de um ponto de vista diferente. Como representação, tornam-se uma voz entre muitas numa arena de debate e contestação social. O fato de os documentários não serem uma reprodução da realidade dá a eles uma voz própria. Eles são uma representação do mundo, e essa representação significa uma visão singular do mundo. A voz do documentário é, portanto, o meio pelo qual esse ponto de vista ou essa perspectiva singular se dá a conhecer (NICHOLS, 2012, p. 73).

Bill Nichols aponta para a inevitabilidade do documentário ser a produção de uma nova voz que não estava presente antes de sua produção. Mesmo quando um documentário busca apenas reforçar vozes pré-existentes a ele, enquanto um novo artefato ele não foge de ser uma representação da realidade e não pode ser identificado como a realidade própria. “No que é considerado hoje um texto clássico, Bill Nichols examina a questão da 'voz' no documentário, usando esse termo para indicar o que um documentário está dizendo, que tipo de comentário sobre o mundo está sendo feito” (CORNER; ROSENTHAL, 2005, p. 8, tradução nossa). Dessa forma, todo documentário é a colocação em jogo no campo da prática social, cultural ou política, de uma nova voz que não estava antes. Nichols esclarece: “Quando uso o termo voz, estou tentando usá-lo para veicular todos os signos, todos os significantes que tenham relevância ou sentido, 
sejam eles verbais ou não-verbais. E os não-verbais são freqüentemente mais importantes que os verbais" (NICHOLS in BONOTTO, 2009, p. 255).

A voz nos estudos de cinema também é entendida como narração. Esta não é produzida somente como discurso oral ou textual, mas depende de muitos canais:

Se a narração no cinema é sempre resultado da interação entre várias instâncias que se manifestam através de materiais heterogêneos, simultâneos, o analista tem sempre de verificar se as várias instâncias (palavra, mise-en-scène, olhar da câmera, montagem, música extradiegética) se organizam para trabalhar "na mesma direção", de modo a fazer sentido em se falar em um ponto de vista da narração. Pode não haver essa conjunção dos canais, como acontece em muitos filmes modernos onde há disjunção, o filme se fazendo do conflito entre as diferenças de posturas associadas aos diferentes canais” (XAVIER, 1997, p. 131).

Ismail Xavier aponta para uma diferença importante entre narração e ponto de vista. No filme documentário, a narração é resultado do trabalho dos cineastas envolvidos, e o ponto de vista pode variar de cena a cena. Quando voltamos ao conceito de voz do documentário de Nichols, no entanto, narração e ponto de vista se comungam para comunicar. Para Nichols, o documentário é o meio que o cineasta documentarista tem para "falar" sobre o mundo.

O filme documentário, ao buscar uma voz que produz o seu posicionamento sobre as questões mesmas de que vai tratar, ou seja, quando faz uma relativa construção da voz do documentário tem que lidar e orquestrar as várias possibilidades de construção dessa voz. As imagens e sons no filme, sua montagem, tudo se abre para várias possibilidades de interpretação, e o documentarista precisa sondar os efeitos interpretativos/receptivos dessas possibilidades. Se o filme documentário não é a realidade, se é apenas mais uma interpretação sobre ela, é também, ao mesmo tempo, um produtor de outras interpretações que não pode controlar. Por mais que a voz do documentário seja construída para produzir efeitos unívocos, ela sempre falha, pois, como "discurso" (FOUCAULT, 1972), ao circular na rede social essa voz tem efeitos múltiplos e contraditórios. Uma voz nunca é unívoca, sendo ela mesma um processamento de relações de produção de discursos e práticas sociais. Nesse sentido, a voz do 
documentário é desde sempre uma multiplicidade e não pode ser reduzida a uma unidade: há uma "heteroglossia”20 (BAKHTIN, 2010, p. 291) inerente a ela. Essas múltiplas vozes estão sempre presentes, por mais que se procure direcionar a representação a uma univocalidade. Mesmo assim e contra toda essa multiplicidade de interpretações possíveis sempre atuantes, um filme documentário muitas vezes busca imprimir ao menos uma voz (ligada a ao menos uma pessoa) como legítima representação de sua própria voz e porque não, sua realidade. Essa relativa legitimação da voz do Outro na voz do documentário pode ser apenas uma estratégia do documentarista; pode ser apenas um efeito nãopretendido pelo documentarista; também pode ser uma estratégia do sujeito filmado documentado/representado, entre outras possibilidades. De todo modo, o que gostaríamos de destacar em nossa pesquisa é que o conceito de voz do documentário permite uma análise simultânea dos efeitos da produção e da recepção dos filmes, e essa talvez seja sua maior utilidade. Ao falar sobre Outros, seja falar sobre ou falar com os Outros - por mais difícil que essa linha tênue seja de diferenciar muitas vezes -, Linda Alcoff sugere que a análise do documentário deve ser sobre os efeitos de sua fala sobre a vida do Outro:

Entramos aqui num outro lado da questão, que consideramos ter sido tocado apenas brevemente por Nichols: para que um documentário tenha voz, é preciso que seja escutado. É preciso que a recepção do documentário seja capaz de escutar essa voz. Para Nichols, isso acontece porque existe um mundo compartilhado entre cineastas, sujeitos filmados e públicos. Seria a partir do compartilhamento de um mesmo mundo que o documentário faria sentido e poderia falar sobre esse mesmo mundo. E é nesse ponto que vemos pesar sobre o conceito de voz do documentário uma incompletude. Para Nichols, a voz do documentário ainda se ouve univocamente. Essa capacidade de se fazer ouvir seria a capacidade do documentarista de, além de saber ouvir Outros sujeitos filmados, também compor uma voz a ser ouvida por um público na medida em que compartilham o mesmo mundo, mesmas linguagens, mesmos modos de representação. Ambos fariam parte de uma mesma comunidade receptiva ao filme. Identificamos, no conceito, uma fé no poder da comunicação unívoca. Por mais que o cineasta documentarista possa trabalhar acionando vários dispositivos cinemáticos em conjunção e utilizar-se até mesmo de artifícios de dubiedade ou até de surrealismo, haveria, ainda assim, uma voz que perpassaria toda essa conjunção de diferentes variedades e que seria ouvida pelo público. Assim, reforçamos a ideia de que uma univocidade perpassa o conceito de voz do

\footnotetext{
${ }^{20}$ Mikhail Bakhtin usa o conceito de heteroglossia para se referir à multiplicidade de vozes ou linguagens existentes em qualquer interação linguística, dado que toda nossa comunicação tem uma história múltipla e anterior a seu uso atual.
} 
documentário de Nichols, assim como talvez esteja também presente em todo o campo de discurso do documentário contemporâneo: um discurso dominante sobre o que pode o documentário. É ao debate sobre esse ponto que passamos agora.

\subsection{A verdade do filme}

Vimos anteriormente que quando o documentário ganha a possibilidade da narração, aquela no estilo $\mathrm{Voz}$ de Deus foi um legado dominante entre os vários usos possíveis. Uma das primeiras reações à Voz de Deus, utilizando esse recurso de forma irônica, pode ser encontrada no filme Terra Sem Pão (1933), de Luis Buñuel. Nele, Buñuel utiliza de um comentário grosseiro nas cenas sobre as pessoas de um povoado da região de Las Hurdes, na Espanha, que vemos em situação de miséria. O texto da narração foi escrito pelo poeta Pierre Unik, que dá o tom por vezes sarcástico do filme, associado ao tema musical, a IV Sinfonia de Brahms. Trata-se de um sarcasmo pelo qual o filme foi criticado duramente, acusado de ser insensível em relação às pessoas filmadas. Vindo da corrente surrealista nas artes, Buñuel fez seu primeiro filme, Um Cão Andaluz (1929), em parceria com Salvador Dalí. Em Terra Sem Pão, o cineasta traz a confusão criativa entre objetividade e subjetividade para dentro de um filme. Acreditamos que tal obra possa ser classificada como documentário na medida em que documenta e faz comentários sobre o mundo vivido. Porém, de forma irônica e sarcástica, talvez seja o primeiro filme que faz alusão à $V o z$ de Deus apenas para descontruí-la. Sua narração assume por vezes um caráter ambíguo, situando-se entre a realização de uma crítica das situações socioeconômicas sofridas pelo povoado, e uma ironia. Entendemos que essa ironia se oferece para múltiplas interpretações, inclusive entender a voz que narra como preconceituosa, tornando possível ler nesse jogo uma crítica à parcialidade do narrador. A única voz que ouvimos é a do narrador e nenhuma perspectiva vinda de alguém do povoado é mencionada. As imagens dependem do narrador para ensinar sobre o que estamos vendo. Mas ao mesmo tempo esse narrador se mostra - ao menos a uma parte dos espectadores - como não confiável. Dessa forma, podemos propor que Buñuel tenha realizado um documentário com base na utilização do recurso à Voz de Deus para fazer a crítica desse mesmo legado a que respondia e foi contemporâneo. Muito cedo na história do documentário, já se sabia que falar pelo Outro é perigoso, que pode ser uma forma de violência, e que documentário é uma representação da realidade, e não a realidade mesma. Consideramos que o filme Terra Sem Pão, como exemplo privilegiado, sirva 
para evidenciarmos todos esses aspectos. Se quisermos considerar a experiência brasileira no documentário, Ilha das Flores (Direção Jorge Furtado, 1989) é um dos grandes exemplos de uma narrativa irônica em seu tom e construção. Nesse caso trata-se de ironizar não somente a linguagem autoritativa do documentário, mas, em conjunto com ela, a da ciência, a linguagem científica que, por vezes, dá o tom das narrações em documentários. Ilha das Flores até hoje surpreende o público, talvez porque ao mesmo tempo que ironiza, faz associações que são a base mesma do pensamento racionalcientífico que critica. Dessa forma, faz um tipo de crítica imanente, em que a linguagem documental-científica é ao mesmo tempo valorizada, pois é utilizada, e criticada.

O caminho traçado por Buñuel, no entanto, é o da crítica a um modelo de documentário, que aqui isolamos entre tantos possíveis, o documentário com narração ao estilo Voz de Deus. Quais seriam outros caminhos? Já mostramos que muitos outros caminhos foram traçados, por diversos movimentos no documentário pelo mundo como o Cinema Direto, o Cinema Verdade, entre outros. A grande mudança no entanto veio quando o Outro sujeito filmado deixou de ser apenas objeto, para ser representado também como sujeito com um ponto de vista e uma vida específica. Os documentários passaram a ouvir vozes por vezes dissonantes entre si, e por vezes a buscar a história a ser contada sem roteiros, na espontaneidade do encontro com o Outro. No Brasil, o maior representante que tivemos de uma vertente da escuta ao Outro foi o documentarista Eduardo Coutinho. Ele desenvolveu filme a filme uma estética e uma ética próprias, relacionadas a compreender a razão do Outro evitando julgamentos. ${ }^{21}$ Coutinho reconheceu a assimetria de poder entre quem filma e entrevista e quem é filmado. E, nesse sentido, defendia que as perguntas do entrevistador - ou "conversante" - tinham que ser ouvidas também nos filmes. Cabe dizer que os diálogos e perguntas realizadas pelo documentarista normalmente são retirados de grande parte dos documentários, mas Coutinho acreditava que isso criava uma ideia de que o documentário estaria "apenas” falando a "verdade". Ele afirmou:

Mas o documentário, ao contrário do que os ingênuos pensam, e grande parte do público pensa, não é a filmagem da verdade. Admitindo-se que possa existir uma verdade, o que o documentário pode pressupor, nos

\footnotetext{
${ }^{21}$ Para aprofundamento na estética, ética e as regras que Coutinho utilizava em cada filme, criando dispositivos específicos para cada um, ver LINS, 2004.
} 
seus melhores casos - e isso já foi dito por muita gente -, é a verdade da filmagem (COUTINHO, 2013, p. 23).

A "verdade da filmagem”, como diz Coutinho, é um conceito antigo, que podemos traçar desde Vertov a Rouch e outros. Ele implica na contingência da filmagem - a presença da câmera, a situação vivida por todos envolvidos no momento da filmagem, as expectativas tanto do Outro filmado quanto do cineasta quanto ao filme e a uma pergunta feita, etc. Implica na construção de um “real” do filme. Para Coutinho, esse “real” é algo muito particular que acontece no encontro com um Outro. Coutinho sabe que esse Outro traz consigo muitas bagagens, e essas lhe interessam, quanto mais particulares, singulares forem. Ele sabe que as pessoas carregam respostas prontas a qualquer pergunta, respondem o que acham que o entrevistador gostaria de ouvir, por isso se coloca na posição de questionador das respostas mesmas dadas pelos entrevistados. O que interessa a Coutinho é o diálogo que acontece, e sendo um diálogo que gera confiança no Outro filmado, esse pode trazer respostas ou momentos inesperados e que a câmera - considerada como também participante e somada a toda a situação da produção do filme - pode ajudar a trazer à tona. "Estou falando do meu "real”, da necessidade que tenho do "real”, dos outros como trampolim de associações e estruturas. Estou falando do real, olhar, documentário” (COUTINHO, 2013, p. 17). Para Coutinho, o real que acontece é o documentário, é a filmagem daquilo que não se repete e que vem, no caso especial dos seus últimos filmes, apenas da voz e presença do rosto do Outro em relação à sua voz como cineasta que conversa. A “verdade do filme” de Coutinho é esse encontro singular, dado também pelo dispositivo ${ }^{22}$ da produção do filme. Coutinho não tem objetivos para um filme além do próprio filme ser o que pode ser. Ele cria seu dispositivo e o segue para encontrar pessoas que nunca viu na vida, nem o viram. São pessoas comuns, e o que elas têm em comum entre si é, por exemplo, o fato de morarem no mesmo prédio, como no filme Edifício Master (2002), ou no mesmo vilarejo, como em $O$ Fim e O Princípio (2006). O que define, portanto, a voz do documentário de Coutinho é tanto seu dispositivo escolhido para um filme, quanto a espontaneidade do que acontece em suas conversas com as pessoas que encontra. Para Coutinho, o Outro serve para fazer

\footnotetext{
22 “Dispositivo”, conceito de Jean-Louis Comolli retrabalhado por Consuelo Lins e Cláudia Mesquita e que remete "à criação, pelo realizador, de um artifício ou protocolo produtor de situações a serem filmadas", de modo a negar a idéia de “documentário como obra que 'apreende' a essência de uma temática ou de uma realidade fixa e preexistente” (LINS; MESQUITA, 2008, p. 56).
} 
filmes e isso se dá numa tentativa de, a marteladas, eliminar tudo que possa remeter o Outro a generalizações fáceis.

A possibilidade de "filmar o que existe", ou de aceitar "tudo o que existe pelo simples fato de existir", é um dos efeitos dos dispositivos de Coutinho. É verdade que essas frases do diretor - dentro de um contexto documental atravessado pela crença na transposição do real para a imagem - provocam mal-entendidos, porque podem sugerir que ele filma a realidade "tal qual ela é", ou que se conforma com o mundo como ele se apresenta: injusto, cruel e desigual. Nada mais oposto ao cinema de Coutinho. O que esse pensamento expressa é um desejo de se esquivar das idealizações que impedem justamente uma aproximação mais efetiva com o que nos cerca. É um movimento que desloca teorias, crenças, interesses, preconceitos, pontos de vista prévios, sentimentos piedosos, culpas e toda a sorte de clichês visuais e sonoros que aderem a nossa percepção e nos fazem acreditar que conhecemos o mundo. Tratase de uma prática que se atém, na medida do possível, ao material oferecido pelo universo a ser filmado - uma favela, um prédio, um morro, um depósito de lixo -, imprimindo aos filmes uma espécie de imanência radical, em que ética e estética se articulam de modo inextricável.

Coutinho provoca e diz que a questão é se "o menos artista possível”. Eu diria que o "menos" a que Coutinho se refere é justamente uma forma de trabalho ou de arte minimalista, que se concentra em uma operação de subtração de tudo o que não lhe parece essencial. Na montagem, isso significa retirar excessos, "fazer buracos", introduzir vazios no material filmado, respeitando, de certa forma, características do que foi captado pela câmera. É um exercício de eliminação que exige um esforço desmesurado e uma postura extremamente ativa e trabalhosa, que pensa, repensa e discute o que está sendo produzido, distante de qualquer passividade ou submissão diante do real (LINS, 2004, p. 12).

O cinema de Coutinho, portanto, não é uma reprodução do real, ao menos em sua produção e discurso do diretor. O Outro de Coutinho não é tipificado, não há generalizações a se fazer por conta do filme em si. Mas esse Outro é construído, tanto na 
criação do dispositivo, quanto na captação, terminando na montagem, em função do que Coutinho acredite ser o melhor que esse Outro tem a dizer. O que o Outro diz, nesse caso, tem a ver com o encontro com a produção de um filme, com a realidade de uma câmera que o filma, e Coutinho sabe que isso produz efeitos nas pessoas, socializadas que estão a pensar a representação e o que pode ter ou não interesse televisivo ou fílmico. Através do dispositivo, de suas perguntas e de sua montagem, Coutinho cria personagens. Mas são personagens que criam a si mesmos, imbuídos do mundo em que vivem. Contra os legados precedentes, dos documentários ao "modelo sociológico", Coutinho cria sua saída para fazer filmes que não são mais apenas sobre Outros, não visam nos dar a conhecer o Outro a fundo, pois não acredita que isso seja possível ou desejável por um filme. A ética e estética dos filmes de Coutinho são fundamentalmente uma recusa à representação do Outro, embora, paradoxalmente, se fundem justamente nessa representação. Para Coutinho, a presença do Outro serve para fazer filmes, e isso lhe basta.

Como aponta Nichols, há características dos documentários dos anos 1990 para cá que trazem à tona tanto as novas possibilidades tecnológicas da era digital -hoje basta um celular na mão para fazer filmes - quanto a guinada ao dialógico que se deu na história do documentário. A voz do documentário passou a ser construída mais e mais em razão das vozes de Outros, muitas vezes incluindo o cineasta como personagem. Filmes passaram mais e mais a mostrar seus bastidores, sua construção, bem como a presença ativa dos cineastas no que sucede em frente à câmera:

Algo pessoal está em jogo aqui, como é sempre num encontro, um fato frequentemente disfarçado por conceitos e categorias que submergem o indivíduo num enquadramento pré-estabelecido, incluindo a observação como um fim em si mesma. A cineasta se torna mais do que um realizador profissional de filmes: ela se torna uma colaboradora e confidente, uma parceira na vida a um grau notável. O que emerge é uma verdade dialógica, o tipo de verdade sobre si que só se chega no e através do encontro, interação e relacionamento. É radicalmente distinto da verdade fatual ou lógica e da verdade pessoal ou subjetiva. Não é o que é verdade para a cineasta somente ou seus sujeitos somente e não o que é verdade sobre o mundo em sua faticidade empírica. É a manifestação do que é verdade quando duas pessoas se engajam uma com a outra e pelo seu engajamento dialógico descobrem para si 
mesmas, e nós, aspectos de nosso ser em comum não evidentes de outra forma (NICHOLS, 2016, p. 70, tradução nossa).

Assim como Coutinho, Nichols também aqui coloca a existência da "verdade do filme” no "engajamento dialógico” entre cineasta e sujeito filmado. Para Nichols, porém, talvez por ser ele um pesquisador do cinema e não um realizador de documentários, a “verdade do filme” se dá de muitas outras maneiras, estando presente inclusive onde não há diálogos, mas há sempre a voz do documentário a falar sua mensagem ao público. Notamos aqui, no entanto, um consenso interessante que temos que entender melhor. Há notadamente em discursos do presente sobre o documentário, uma celebração da “verdade do filme”, do encontro que cria uma "verdade dialógica” entre cineasta e sujeito filmado. É como se, na história do documentário, tivéssemos passado de uma relativa dominância de discursos autoritativos na Voz de Deus, para o que seria seu oposto hoje celebrado, a construção da "verdade do filme" entre cineasta e seus Outros sujeitos filmados. Além de Nichols e Coutinho, essa tendência a valorar a "verdade do filme" perpassa o discurso de outros estudiosos do documentário e documentaristas nos dias atuais. Notamos no Brasil uma tendência de dos nomes mais conhecidos entre documentaristas e pesquisadores do cinema, a desqualificar documentários que sejam considerados unívocos. Como escreve Amir Labaki (2006, p. 89):

A inquietação estilística desta nova geração reflete a nova liberdade alcançada pela ruptura do documentário com o padrão griersoniano dominante na história do gênero no Brasil. A “pedagogia utilitária”, para usar um termo do próprio João Moreira Salles, não mais monopoliza o gênero no Brasil.

A tendência no discurso hoje dominante entre documentaristas e pesquisadores do documentário no Brasil é valorizar filmes que rompam claramente com posicionamentos unívocos e pedagógicos. Os filmes valorizados são aqueles em que há "fascinação" e “inspiração” com o Outro (NICHOLS, 2016, p. 72), quando essas reações vêm dos encontros do cineasta como personagem do filme, o valor parece aumentar. Além dos documentários de “verdade dialógica”, o “documentarismo subjetivo” (LABAKI, 2006, p. 87) é valorado como mais fiel a uma realidade que seria sempre fragmentária, onde memória/história e ficção/realidade/imaginação constróem o filme. Esses novos modos 
de representação do documentário são por um lado mais abertos à interpretação, deixam mais pontos em aberto em geral para a imaginação do espectador. Certamente, alguns documentaristas, temendo a responsabilidade do fechamento de representações sobre o Outro, optam por deixar ao espectador qualquer generalização ou afirmação sobre o Outro ou sobre as contingências da situação ou da história representada. Mas o fato notado por muitos estudiosos do é que há um novo discurso e prática dominante "o documentário hoje [no Brasil]: lugar de produção de imagens "menores”, da realização de auto representações, da afirmação da diversidade de experiências, identidades e linguagens”. (LINS; MESQUITA, 2008, p. 13).

Vimos que com Nichols afirma que voz do documentário, aquela mesma que seria responsável pela “verdade do filme”, é o cineasta que produz, que cria dispositivos, que escolhe ângulo, locação, perguntas a serem feitas, e no final realiza a montagem, criando uma narrativa. Se é o cineasta quem faz tudo isso como criador da voz do documentário como esse filme pode ser dialógico e não apenas suas cenas? A voz do documentário pode ser criada entre vozes de Outros - mas com qual direção? Para entreter apenas? Ou pela glorificação da interação humana?

Em sua tese de doutorado intitulada Ponto de Vista A(u)torizado: Composições da Autoria no Documentário Brasileiro Contemporâneo (USP, 2013), Mariana Silva demonstra que por mais dialógico que possa parecer, o documentário sempre precisa ser pensado a partir da autoria em todas as suas instâncias, que há níveis de controle da representação que podem estar apenas do lado do cineasta e não do Outro sujeito filmado:

Trata-se então de uma discrepância que se perfaz em cascata: o primeiro nível - mais elementar - diz respeito à consolidação de um lugar de autor que estabelece, de saída, as condições do jogo, os limites da própria interlocução: lança as perguntas (que eventualmente se apagam no processo de montagem) e espera as respostas. O segundo, já explicitado, refere-se à posse das condições de produção e da fluência quanto à linguagem do próprio documentário. Tentar elidir essa distância no mais das vezes redunda em uma expropriação da alteridade, que tem sua potencialidade de interlocução desqualificada: "Porque, simplesmente, não se dialoga com entrevistado pobre. Há como que uma dupla atitude em relação a esse tipo de entrevistado. Por um lado, uma relação fetichista: tudo o que diz o pobre vale; não vamos contradizer o pobre, que isso implicaria uma colaboração com os 
mecanismos de opressão - entrevistado pobre é um tanto sacralizado. Por outro, não passa de matéria-prima para os filmes.” (BERNARDET, 2003: 294-295). Se assistimos ao esgotamento da entrevista como estratégia de produção de sentidos para além do lugar-comum, a exemplo do que ocorrera com os comentários em voz over na conjuntura do modelo sociológico, isso não se deve, evidentemente, pela colocação em cena da fala do outro, mas pela forma de agenciamento desse recurso. No caso dos entrevistados que servem de matéria-prima aos filmes, majoritariamente ilustrando as teses do realizador (em um resquício do mesmo modelo sociológico, em que a autorização do lugar de autor se efetivava pelo exercício comprobatório/ilustrativo/explicativo), seus atos de fala frequentemente parecem extorquidos (SILVA, 2013, p. 95).

Um documentário pode, portanto, incluir entrevistas ou conversas e ter um certo nível de autoria por parte do Outro sujeito filmado, mas isso não garante isonomia das decisões, poderes e saberes de representação entre este e cineastas. Se ao Outro sujeito filmado não é dada a autoria nas decisões sobre sua representação, se há pouca ou nenhuma colaboração nesse sentido, devemos nos perguntar até que ponto podemos realmente pensar em “encontro”, “diálogo” ou mesmo “relação”, se esta é sempre desigual. Se o único propósito do convite ao Outro é que se torne personagem de um filme, um personagem para um cineasta que depois tem para si a decisão sobre a montagem, podemos nos satisfazer com a declaração de que ali ocorre apenas um “encontro" como se fosse algo fortuito, sem intenções, poderes institucionais, relações assimétricas?

Quando se usa a voz humana para pronunciar palavras num diálogo ou conversa, temos mais do que apenas a emissão de sons e palavras. Particularmente no documentário, utiliza-se muitas vezes da presença do corpo do sujeito falante em imagem. Para ouvirmos a voz do Outro é preciso ter seu som. Mas “vozes, no entanto, podem fazer muito mais do que falar textos ou aludir a ideias, e uma outra maneira de lidar com a complexidade da presença não é se voltando para a interioridade do ser mas se abrindo para a comunicação intersubjetiva entre corpos materiais.” (THOMAIDIS, 2017, p. 25, tradução nossa). A comunicação intersubjetiva é o que Nichols e Coutinho estão, por exemplo, a valorizar como “verdade do filme” na voz do documentário. Essa se dá para eles na percepção de que maneira o cineasta se abre para não julgar de forma 
moralista ou final o seu interlocutor, o sujeito filmado. Entre cineasta e sujeito filmado não há presunção de igualdade plena. Há diferenças de classe, raça, e de poder sobre a imagem que são reconhecidas e que servem inclusive como base da conversa que acontece em frente à câmera. O documentarista precisa saber ouvir, mais do que falar, para que haja a conversa. E saber ouvir atentamente, sem precisar fingir nada. Existe uma ética de respeito pelo Outro no documentário da "verdade do filme” ou "documentário dialógico”. Mas como já colocamos, esse respeito existe ali muitas vezes já numa ordem assimétrica, guiado por quem decidiu filmar, por que motivo, com qual intenção, etc.Quem vai montar a narrativa, não é o Outro sujeito filmado. Todo dispositivo que é escolhido para um filme, necessariamente faz mais do que incluir vozes. Ele é também um meio de silenciar outras vozes. Dispositivos podem criar oportunidades para vozes, mas sempre por necessidade também silenciam outras, pois são, por necessidade, limitadores, facilitam um trabalho e ao facilitarem precisam reduzir e silenciar sobre alteridades. Todo encontro com o Outro, particularmente se é construído através de técnicas como a entrevista, produz vozes e ao mesmo tempo silenciamento. Podemos saber do Outro apenas aquilo que ele fala ali na entrevista, ouvimos de um Outro entrevistado sobre sua esposa apenas o que ele fala, podemos nunca ouvi-la, vê-la, pois o dispositivo da entrevista assim o fez num dado filme. O Outro já carrega consigo representações as quais foi socializado e muitas vezes busca apresentar a si mesmo de uma maneira teatralizada para causar certo impacto.

Indivíduos desprovidos de uma educação mais formal revelam consciência notável a respeito de sua imagem pública, exibem sabedoria intuitiva do que pode "funcionar" em uma entrevista (...) Esse estado de coisas deve ser levado em conta - especialmente por aqueles que constroem filmes a partir da palavra do outro, sob pena de imprimirem, sem o saber, maior existência social e mais crédito a pensamentos e emoções que têm origem nos próprios clichês que a televisão faz circular (LINS, 2008, p. 46).

Há, na cena do documentário contemporâneo, muitas exceções à utilização do Outro como apenas o sujeito que fala. Há filmes, como Two Laws, que já citamos, deixando todo o controle da filmagem e edição para os Outros sujeitos filmados. Há outros, como O Prisioneiro da Grade de Ferro - Autorretratos (Direção Paulo 
Sacramento, 2003), que partem da filmagem realizadas pelos Outros sujeitos filmados, numa semi-auto-representação ou coautoria, pois a montagem ainda ficou a cargo do diretor. Esses filmes inserem de alguma forma o Outro sujeito filmado como cocriador e até codiretor.

A questão que queremos colocar agora vem de outra ordem e não diminui a relevância ou importância dos filmes que prezam a "verdade do filme”, para usar o termo de Rouch.. Em documentário, não se constrói a "verdade do filme” sem o "peso do mundo” (RAMOS, 2008, p. 81). Vamos nos fixar num filme em específico para falar desse "mundo" e do Outro filmado. O filme Edifício Master (2002), de Eduardo Coutinho, vai ser nosso apoio para não corrermos o risco aqui de generalizar demais sobre o discurso da "verdade do filme". Trazemos aqui na íntegra um texto do crítico de cinema Inácio Araujo, publicado no jornal A Folha de S. Paulo logo após o lançamento do documentário, que nos ajudará a pensar os efeitos e interpretações possíveis a partir do filme:

Filme apresenta mundo como ficção plena

INÁCIOARAUJO

CRÍTICO DA FOLHA

Quem espera de "Edifício Master" grandes revelações sobre a vida secreta em um cortiço vertical esqueça. Tudo se passa como se Eduardo Coutinho tivesse feito este filme antes de tudo para frustrar nosso voyeurismo.

Os personagens que habitam esse prédio de Copacabana com mais de 20 apartamentos por andar não têm nada de especial a dizer, e sua diversidade é grande o bastante para configurar uma espécie de representação em escala do que seja o Rio de Janeiro na virada para o século 21.

Moram ali jovens músicos, senhores aposentados, técnicos de futebol, camelôs, prostitutas, mães solteiras.

A amplitude da amostragem é desnorteante, e é apenas isso que credencia o edifício, entre tantos, a se tornar o lugar privilegiado de um filme. Aliás, já nas cenas iniciais, o síndico avisa que os tempos de decadência são passado. O Master é um prédio como qualquer outro. O que vem a seguir não irá desmenti-lo. 
Qual, então, o interesse do filme? "Santo Forte" (1999), do mesmo Coutinho, tinha a propriedade de atirar o espectador em um registro muito particular: captava discursos de natureza religiosa, isto é, que dizem respeito diretamente ao imaginário, de tal modo que a ficção se instalava no coração das imagens e de certa forma nos arrastava.

No "Master", nada disso. Lá estão a garota renegada pelos pais por ter engravidado, o senhor que encontrou a mulher nos anúncios de jornal, as irmãs solteiras que passaram a vida juntas (uma delas se ocupando da outra e da mãe, ambas doentes), a poeta desempregada. Etc.

Com exceção do aposentado que emigrou para os EUA quando jovem e, à parte deixar seus três filhos por lá, cantou certa vez com Frank Sinatra, as histórias são prosaicas. Talvez a cena final, noturna, em que os apartamentos são vistos de fora pela câmera, desminta tudo o que foi dito aqui (ou seja, antes, seu corolário).

Nesse rápido instante, vemos não mais que silhuetas, figuras que não chegamos a identificar. Existências fechadas em si mesmo, cujo mistério permanece intacto apesar de tudo que, agora, sabemos a seu respeito (a cena lembra um pouco quadros de Edward Hopper que, à força de realismo, acabam nos falando da irrealidade do mundo).

Talvez, na verdade, "Edifício Master" comece depois que termina. Isto é, quando saímos à rua e deparamos com nossos semelhantes.

E, por um momento, podemos pensar que habitualmente não conhecemos das pessoas nada mais que a casca, a aparência. E que qualquer uma delas (isto é, qualquer um de nós) tem um discurso, um ponto de vista, uma história a contar. E que qualquer história pode ser interessante, porque todas as vidas o são.

É apenas então -já terminado- que o filme nos restitui à atmosfera ficcional de "Santo Forte", embora num grau de radicalidade maior. Se neste entrávamos em contato com a ficção que cada um cria para si (sob a forma, no caso, de discurso religioso), aqui é o mundo que se apresenta como ficção plena, fascinante, na medida em que cada corpo é investido de uma história: aquela que cada um narra a si mesmo e que faz de cada ser um mistério.

Daí, talvez, o formidável achado que é "Edifício Master": cada cubículo contém um mundo particular e fechado em si mesmo. Vistos de perto, esses cubículos configuram um labirinto. Talvez esse labirinto seja cada um de nós, talvez a soma de todos. 
Talvez, por fim, seja preciso ver Eduardo Coutinho como o criador de um gênero paradoxal: o documentário fantástico. ${ }^{23}$

Araujo começa dizendo que o documentário frustra o voyeurismo. Esse termo, numa acepção mais rígida, denota o ato de uma pessoa que olha pelo buraco da fechadura, com vistas a cenas de sexo ou de atração sexual. O filme A Janela Indiscreta, de Alfred Hitchcock é um clássico do cinema que além de retratar o voyeurismo de um fotógrafo em relação a uma mulher que ele vê da sua janela sem ser visto, remete ao próprio voyeurismo inerente ao cinema. Pela janela da tela vemos como espectadores sem sermos vistos. Não seria o voyuerismo - sem a conotação sexual - necessário ao cinema? Ver como outros vivem, o que fazem até em seus espaços privados? Não seria uma das grandes atrações do documentário, justamente perscrutar a vida dos outros? A diferença é que em grande parte dos documentários, o Outro filmado consentiu de alguma forma a ser filmado. No entanto, a motivação de quem assiste ainda pode carregar muito do voyeurismo que é alimentado pelos filmes mesmos ao modo: “venha conhecer como vivem essas pessoas aqui!” Araujo mesmo demonstra voyeurismo, uma insaciedade sobre a vida dos outros - seria o caso dos cinéfilos em geral? - ao afirmar: “qualquer história pode ser interessante, porque todas as vidas o são.” O voyeurismo é algo consciente até para o entrevistado, que atua muitas vezes para a melhor cena, mais impactante possível. Sobre Edifício Master, filme no qual Consuelo Lins trabalhou, afirma ela:

Houve momentos nos quais foi preciso defender o entrevistado dele mesmo, em que a lógica do pior se impôs, e o que se ouviu foi a pior história, a maior desgraça, a grande humilhação. Porque o desejo dos moradores, em muitos casos, é o de escapar do isolamento, ganhar visibilidade a qualquer preço. O confronto com esse tipo de exibicionismo, indissociável do voyeurismo do espectador, é incontornável e transformou-se hoje em imperativo para o documentário (LINS, 2008, p. 49).

Araujo em sua crítica diz que Edificio Master mostra uma diversidade de pessoas, que não se alinham a um tipo - pois o filme não os categoriza sociologicamente como tal.

\footnotetext{
${ }^{23}$ Fonte: https://www1.folha.uol.com.br/fsp/ilustrad/fq2211200210.htm Acesso em: 29 out. 2019.
} 
No entanto, afirma que essa "diversidade é grande o bastante para configurar uma espécie de representação em escala do que seja o Rio de Janeiro na virada para o século 21.” Com essa afirmação, Araujo mostra que há espectadores como ele que sempre vão generalizar o que vêem, por mais que o filme não o faça. Espectadores, especialmente se estão familiarizados com a vida e população do Rio de Janeiro e especificamente de Copacabana, dificilmente escapam de abstrair e comparar as pessoas do filme com outras que elas já conheceram, acabando por caracterizar essas pessoas como fazendo parte de alguma comunidade, grupo, classe, tipo, ou outras formas de enquadrá-las sociologicamente. A representação sobre "tipos" de pessoas, que vem junto com expectativas sobre essas pessoas, faz parte da socialização de todos, sendo isso um fator fundamental para um indivíduo poder navegar pelo social. Araujo, portanto, não faz diferente do que uma parte do público certamente faria: logo se põe a pensar para além do Edifício Master, na sua concretude, para outros edifícios e lugares. É por isso que ele afirma na sequência: “Talvez, na verdade, "Edifício Master" comece depois que termina. Isto é, quando saímos à rua e deparamos com nossos semelhantes.” O filme, portanto, por mais que seja feito para a "verdade do filme" segundo seu cineasta, faz muito mais que isso, e aponta para o mundo.

Ismail Xavier também enaltece a novidade trazida por Coutinho em sua diferenciação em relação à tradição sociológica no documentário:

Edificio Master inaugura um movimento de consulta que se afasta daquele usual contato que elege as classes populares, comunidades marcadas por uma forte personalidade enquanto grupo (ligado pela religião, o espaço de moradia, a classe social). Trata-se agora do mergulho no que lá atrás se definia em Arnaldo Jabor como o terreno da “opinião pública”, observada a partir de uma ótica específica, com ênfase para a uniformidade, a partilha do medo e do conservadorismo. Aqui, se há em Coutinho uma recusa das posturas apriorísticas que lembra aquela tônica de "dar voz" ao outro, típica dos anos 1960 e 1970, a sua investigação empírica tem outros pressupostos, pois não se atém a perguntar o que pensa o sujeito a respeito de certo tema de relevância para a discussão política. Ao não se conformar com os clichês da fragmentação, da crise do sujeito e da massificação consentida, seu horizonte é um movimento contrário de afirmação, de encontro com narradores, figuras capazes de falar sobre sua experiência, 
expor um imaginário, figuras que, curiosamente, buscam ser personagens no sentido clássico, não propriamente figuras da alienação e da fragmentação, não-sujeitos. O que resulta desta tensão entre convite à abertura e um possível abrigar-se na convenção é muito variável, e a leitura de cada cena é sujeita à controvérsia. (XAVIER, 2010, pp. 76-77).

Vemos que a novidade inaugurada por Coutinho é a rejeição a qualquer generalização sociologizante. Certamente, ele abriu novos horizontes para o documentário no Brasil e no mundo. A recusa em escolher como sujeitos, representantes do que quer que seja, abriu novos ares para um documentário que não almeja nada além do encontro com um Outro. Sua recusa é uma resposta direta aos modos até então dominantes no documentário. Ele afirmou:

Nenhum filme filma a verdade. Se você fizer um filme etnográfico, a câmera ficar parada três horas no quintal e depois quatro horas em uma mulher socando pilão, é uma ilusão que o cineasta está conhecendo o real. Ele está documentando um encontro entre o cineasta e o mundo, sempre. Eu não filmo senão esse encontro, filmo uma relação. (COUTINHO, 2008, p. 110).

Na mesma linha, o documentarista João Moreira Salles apontou que

Nos últimos anos o cinema documental vem tentando encontrar modos de narrar que revelem, desde o primeiro contato, a natureza dessa relação. São filmes sobre encontros (...). Filmes assim não pretendem falar do outro, mas do encontro com o outro. São filmes abertos, cautelosos no que diz respeito a conclusões categóricas sobre essências alheias. Não abrem mão de conhecer, apenas deixam de lado a ambição de conhecer tudo (SALLES, 2005).

Às posições de Coutinho e Salles, documentaristas, podemos contrapor as de Araujo e Xavier, pesquisadores do cinema. Se por um lado os documentaristas colocam que não fazem generalizações, ou que ao menos são “cautelosos”, por outros os críticos e estudiosos do cinema indicam que as generalizações e julgamentos ou tipificações 
acontecem do lado do público espectador. Embora Xavier afirme que os sujeitos filmados de Edifício Master "não propriamente figuras da alienação e da fragmentação, nãosujeitos”, por outro, reconhece que “a leitura de cada cena é sujeita à controvérsia.” E aqui chegamos num ponto fundamental em relação à voz do documentário no caso da “verdade do filme” de Coutinho e de outros filmes contemporâneos, um ponto pouco refletido nos estudos em cinema: a recepção, o modo como as pessoas consomem, interpretam e vivenciam filmes.

\subsection{A voz do documentário e o mundo que o cerca}

Os estudos de recepção de mídias como o documentário apontam hoje para o caráter ativo do espectador, que traz sua bagagem cultural, suas socializações em relações linguísticas, de poder e institucionais ao encontro do que assiste na tela do filme. O espectador age sobre o que vê e ouve, em parte conscientemente, em parte não. Sua leitura do mundo sempre está presente. Sendo assim, a recepção de um filme, devemos esperar que seja múltipla e contraditória. Podemos começar com uma colocação muito simples. Há filmes de que gostamos e outros de que não gostamos, como espectadores. Nosso gosto não é apenas racional, é emocional também, é cultural, é histórico - no

sentido de que gosto é algo construído numa vida específica. Gosto é também valor. É aquilo que um indivíduo, dentro de sua cultura e contingência histórica, coloca para si como mais valioso. Escreveu Friedrich Nietzsche:

E vocês me dizem, meus amigos, que não há disputa de gosto e degustação? Mas toda a vida é uma disputa sobre gosto e degustação. Gosto - que é ao mesmo tempo peso e escalas e o pesador; e ai de todo o vivente que viveria sem disputas sobre peso, escalas e pesadores! (NIETZSCHE, 1986, p. 129).

Nietzsche se refere à impossibilidade de qualquer imparcialidade, à necessidade inextricável de julgar e ser julgado pelo Outro. Toda disputa que coloca-se como "a melhor maneira de...” é fundamentalmente uma disputa de gosto. E gosto, para Nietzsche, é tudo que se discute, e em tudo que se discute, fundamentalmente está o gosto e o valor. O estabelecimento de alguma verdade esconde gosto, esconde também uma "vontade de 
verdade" que é também uma "vontade de poder". Nietzsche mostra como a "vontade de verdade” na cultura ocidental é socializada através da moral cristã que provocou sujeitos a quererem uma pureza que só poderia ser encontrada na interioridade dos sujeitos. Nietzsche inaugurou o estudo da história da subjetividade e da moralidade.

O que torna a história da subjetividade e da moralidade importante é para Nietzsche uma questão prática. A história ligada a isso é a passagem de uma cultura prémoral - da qual ele vê representantes nos filósofos pré-socráticos - para uma cultura moral, psicológica. Nessa última, em que ainda estamos imersos hoje, as intenções tornam-se mais importantes do que os efeitos das ações. A intenção está ligada à vontade de ser bom em uma interioridade, apesar do mundo. O cristianismo impulsionou a formação de sujeitos privatizados ao considerar o mundo como mal e a interioridade como o espaço da comunidade, com base na "crença compartilhada." ${ }^{24}$ Isso também se tornou o espaço de intervenção, uma vez que se tornou considerado como a origem das ações. O próprio Nietzsche afirma o subjetivo como um espaço para a transformação. No entanto, suas ideias sobre subjetividade são uma rejeição do sujeito estável; para ele, o sujeito é sempre multiplicidade. Seu projeto é levado adiante por Foucault, particularmente em relação à história da subjetividade, verdade e moralidade. Para Foucault, “Há sempre o trabalho da 'vontade de verdade', que constrói, dentro de seu próprio espaço legitimador, alguma narrativa de significado que recupera seu próprio passado construído.” Dessa forma, para Foucault todo discurso sobre objetos e sujeitos é uma “recuperação" construída visando determinados fins. Podemos entender com Foucault, porque é que quando as formas de se fazer documentário se desligam reativamente até - da Voz de Deus, do sociologismo, do documentário militante de dar “voz ao povo" - o discurso passa a ser de rejeição a qualquer sinal que possa ser identificado com esses legados. A reconstrução do passado que é feita constrói uma barreira entre o que veio antes e depois. A crítica feita ao passado, passa a categorizar esse passado como "menos": menos criativo, menos humano, menos arte, etc. O discurso hoje dominante sobre o documentário rejeita os modelos dominantes do passado, como passado. E ao fazê-lo, priva de possibilidades de diferença o próprio documentário. Devemos sempre fazer a crítica dos legados da Voz de Deus, do sociologismo, etc. Mas ao acreditar que rompemos totalmente com essas tradições, que não as reproduzimos, mesmo quando, reativamente, as rejeitamos, podemos novamente estar a trazer de volta

\footnotetext{
${ }^{24}$ Devo esses argumentos e entendimento sobre Nietzsche a meu professor Richard Shapiro.
} 
os documentários sociologizantes. Por que? Porque todo espectador é sociologizante, necessariamente projeta sobre a tela suas socializações. Não seria, portanto, suficiente que o cineasta pense em sua ação correta, seu ouvido atento, seu julgamento seja paralisado. O cineasta é apenas parte do processo, importante, mas apenas uma parte. Não há como evitar que espectadores julguem os personagens de Edifício Master como “propriamente figuras da alienação e da fragmentação” como gostaria Xavier. Pois cada espectador traz suas relações com o mundo para o momento de sua leitura da voz do documentário. E só assim é que a voz pode ser ouvida: com os ouvidos dos espectadores específicos. Com Nietzsche e Foucault, aprendemos que as ações são mais do que as intenções e as práticas são sempre relacionais e intermináveis: um filme, enquanto produtor de verdade, tem vida própria e ao circular, produz efeitos diversos, inclusive não-programados, até incontroláveis. Dessa maneira, podem sempre fazer justamente o contrário da vontade do seu realizador, e devemos esperar que assim seja.

Nietzsche e Foucault fornecem maneiras de pensar sobre a verdade e moralidade que escapam à paralisia que o pensamento moral acarreta. Suas avaliações são de que não devemos esperar pelo conhecimento "completo" ou "todo-abrangente" para agir. Eles não participam da crença de que o conhecimento é primordial para a ação, ou de que é preciso dominar-se para agir eticamente. Para eles soaria absurda a ideia de que para que tenhamos a "verdade do filme”, bastaria que o cineasta se pusesse a escutar sem julgar. Pois o julgamento já se iniciou quando foi tomada a decisão de se fazer um filme, e escolhidos os Outros a filmar, e como filmar! O gosto por fazer, por quem filmar e como filmar, raramente é partilhado entre cineasta e sujeitos filmados. E quando o é, ainda temos a questão da audiência: quem são, quem vai escutar o filme, com quais ouvidos? Com quais relações de poder e saber projetadas sobre a tela do filme - até mesmo contra as intenções dos cineastas e realizadores?

Para ambos os pensadores, a razão (como universal, metafísica) e a moralidade resultam e são métodos para a construção de fundações, origens e princípios que orientam a ação, na cultura ocidental dominante. Essas suposições participam de batalhas morais que empurram a ação para as margens enquanto priorizam respostas anestesiadas, até reativas. Agir a partir de um espaço de conhecimento total, obrigação moral ou da crença em unidades fictícias é promover a aniquilação da diferença. A vida como aparece, então, é automaticamente categorizada e domada através dos rótulos do certo, justo, bom, correto e moral. Nietzsche quer avaliar a ação a partir da pergunta "Isso é um fator que melhora a vida ou nega a vida?”. Foucault está interessado em avaliar a ação sob a 
perspectiva da diferença e da possibilidade social. A avaliação seria na forma de "Quais são os efeitos dessa ação, em múltiplos contextos e formas de conhecer?” Em última análise, porém, as questões para ambos os pensadores não devem ser tornadas cognoscíveis. Eles não devem se tornar exatamente aquilo que desafiam: a capacidade de conhecer a ação. Eles só servem aos seus propósitos quando respondidos no contexto e com o menor componente de um conhecimento universalizado possível. Não há nada para Nietzsche ou Foucault que sirva como base para toda ação, ou para o pensamento. Nem mesmo a verdade ou a moralidade, por mais que a vontade de ver a verdade e a moralidade, a vontade de bondade, seja difundida na cultura cristã secular. Nietzsche diz que sempre "o homem ... procura a verdade apenas para fazer o bem -, pode-se dizer, e eu a sustento, que não se pode encontrar nada.”

A "verdade do filme” é verdade de que tipo? Para quem? Isso vai mudar conforme o público, e pode ser diferente para os diferentes sujeitos filmados de um mesmo filme. Quem é o pesador? O que ele gosta? O que ele quer da vida, sua e dos Outros? Isso tudo sempre influencia um filme. Quem pode, afinal, decidir, medir para nós se um “diálogo”, ou "encontro” entre cineasta e sujeito filmado acontece ou não? Onde está essa régua? Se ela existisse, fazer documentários seria fácil. Mas essa régua existe apenas no processo em que cada espectador (cineasta incluso) foi socializado, que teve seu processo de subjetivação ${ }^{25}$ realizada. E, com isso, toda afirmação de certa isonomia de poder e de saber entre cineasta, sujeito filmado e espectador, é discurso, é colocação em jogo de uma verdade que circula apenas quando as regras do jogo são compartilhadas. Não há régua que possa medir isonomia de poder ou saber entre sujeitos. No fim, quando algum espectador afirma que enxerga isonomia de poder, ou que enxerga "diálogo" ou “encontro", estamos falando de gosto. Não temos réguas para medir a verdade intersubjetiva. A “verdade do filme”, talvez exista, talvez não, e isso é uma questão de gosto e socialização, em cultura fílmica e acadêmica, por exemplo.

O grande “Não!” aos comentários, narrações, montagens em documentários que querem falar do Outro - com diferentes meios de obtenção de registro - presente nos discursos sobre o documentário nos dias atuais, reflete uma questão de gosto político e estético, esse gosto foi criado como ao mesmo tempo repulsa ao passado do documentário, e como um meio de salvaguardar o documentário e o documentarista do

\footnotetext{
${ }^{25}$ Foucault define a "subjetivação" como “o procedimento pelo qual alguém obtém a constituição de um sujeito, ou mais precisamente, de uma subjetividade que é claro é apenas uma das dadas possibilidades de organização de uma auto-consciência (FOUCAULT IN MARGOLIS, 1993, p. 59).
} 
encontro politizado com Outros, onde os modos e meios de produção não estariam talvez mais nas mãos de cineastas apenas. Não se trata apenas de rejeitar a Voz de Deus, ou abstrações generalizantes sobre uma cultura, povo, nação, religião, etc. O que se constrói como discurso é que o "modelo sociológico" deve ser evitado. Com isso, entende-se saber do que se está falando. Em que ponto começa e em qual termina o "modelo sociológico”? Nós mesmos fizemos aqui, nessa pesquisa, a crítica que também tem como alvo esse "modelo". Mas quando se fala em "modelo" em filmes, será que estamos atentos ao modo como o filme vive no mundo? Será que estamos analisando os efeitos do filme na vida das pessoas? Será que um voice-over "autoritário” que nos diz "precisamos da sua ajuda para salvar essas vidas” precisa ser considerado “sociológico” porque toma lado, mostra um discurso unívoco e isso seria nosso “modelo” do passado a ser jogado fora? Não seria esse nosso parâmetro para avaliar filmes que visam ser aliados de Outros, o quão conseguem sê-lo? E se não conseguimos réguas ou medidas de “impacto" ${ }^{26}$ de um filme na vida das pessoas, isso seria o bastante para desqualificar a busca pelo “impacto”? Será que estamos atentos que àquilo que Stuart Hall nos faz ver, que é a questão de que uma produção audiovisual só pode ser pensada em toda a sua complexidade se considerarmos tanto a produção, quanto a sua circulação e recepção, o modo como os filmes vivem uma vida e produzem efeitos? Afirma Hall (2006, p. 165, tradução nossa):

Philip Elliott expressou este ponto sucintamente, dentro de uma estrutura mais tradicional, em sua discussão sobre a maneira pela qual o público é tanto a "fonte” e o "receptor" da mensagem de televisão. Assim - para pedir emprestado a Marx seus termos - circulação e recepção são, de fato, “momentos” do processo de produção na televisão e são reincorporados, através de uma série de "feedbacks" distorcidos e estruturados, no próprio processo de produção. O consumo ou recepção da mensagem televisiva é assim também um “momento” do processo de produção em seu sentido maior, embora este último seja "predominante" porque é o "ponto de partida” para a realização da mensagem. Produção e recepção da mensagem da televisão não são, portanto, idênticas, mas estão relacionadas: são momentos diferenciados dentro da totalidade formada pelas relações sociais do processo comunicativo como um todo.

\footnotetext{
${ }^{26}$ Organizações de financiamento de documentários como a Doc Society exigem cada vez mais que filmes documentários tenham "impacto" e buscam caminhos para compreender como avaliá-lo.
} 
Hall fala aqui de televisão, mas queremos puxar seu debate para o filme documentário especificamente. Se entendemos que produção e recepção estão relacionadas, de modo que: toda produção de um filme se faz dentro de um corpo social que é formado pela linguagem - incluindo as linguagens técnicas de produção -; essa produção entra em circulação e é recebida e consumida conforme os processos discursivos dominantes e outros intervém sobre essa recepção; depois é no momento seguinte que a própria recepção pode ser reprodutora de novas produções, mesmo que venha a reproduzir transformando. O processo comunicativo se dá nesse loop , portanto temos que considerar que um filme sempre responde - quer queira ou não - a produções culturais anteriores. Os produtores de filmes precisam sempre estar atentos aos modos em que se pode dar a recepção, e para isso contam com os modos pelos quais as recepções já se deram para outros filmes e produções culturais. Ainda assim, os cineastas não controlam a recepção, pois como linguagem que é, um filme diz sempre mais - ou menos, dependendo da recepção - do que querem seus produtores. A "mundanidade" (SAID, 2007, p. 84) do filme é sempre presente, todo o contexto de sua produção é tão importante quanto o de sua circulação e recepção, se queremos entender o que pode um filme. O filme sempre pode ser interpretado como se referindo ao mundo "real" e tem efeitos sobre o mundo nesse sentido.

Hall parte do entendimento de que o audiovisual é uma produção da coletividade, sempre utilizando das linguagens disponíveis, mesmo para subvertê-las. Com Hall podemos dizer que a voz do documentário só pode de fato ser uma voz, no sentido de uma linguagem, se têm lastro numa coletividade. Nesse sentido, temos que alargar o conceito de Nichols e perceber que o cineasta tem apenas parte na criação da $v o z$ do documentário, porém o cineasta não é determinante. O cineasta não produz num vácuo de linguagem e recepção. Se há voz do documentário, ela precisa ser ouvida. E para ser ouvida, ela o será de diferentes maneiras a depender da "comunidade de interpretação" (FISH, 1980) onde o filme documentário circula. Um filme que se diz não-político, pode ser lido como político, e outro que se diz político, pode ser lido ao contrário. Jean-Pierre Esquenazi (2011, p. 200) aponta para o caráter sociocultural e historicamente situado das produções culturais que são filmes quando afirma que

Não há leitura política dos produtos culturais que não seja coletiva. (...) Um produto cultural (...) não se torna uma obra política a não ser que 
ele encontre um grupo social que seja capaz de endossar essa qualificação [do político] aos olhos do espaço público. (...) Trata-se de uma articulação entre uma produção industrial e uma produção de significações para um coletivo humano. Nós designamos (com Stanley Fish) um coletivo que faz esse papel como uma comunidade de interpretação.

Um filme é aquilo que o seu público o torna. Filmes são feitos para públicos, mas são os públicos que lhe dão vida. Filme que não se vê, que não circula, não vive. Filme que circula, necessariamente afeta a vida das pessoas de alguma forma, seja para confirmar suas posições, seja para movê-las em novas direções. A própria história do documentário o atesta: documentários são produzidos no presente, em grande parte, como resposta ao passado. Na atualidade, documentários poéticos, subjetivos, filmes-ensaio, autobiográficos, os chamados criativos, entre outros, permeiam os festivais de cinema e são entendidos por muitos críticos como "melhores” ou mais "avançados” do que os “militantes”, “sociológicos”. A circulação de filmes, portanto, é sempre politizada. Aos documentários rotulados por muitos como ultrapassados, pois tomam partido, escolhem pontos de vista sobre outros, são "engajados demais numa causa”, sobrou serem vistos como não inovadores, como se a inovação fosse um valor em si mesmo. Um dos grandes críticos do "modelo sociológico” é Jean Claude Bernardet, que afirmou, em uma crítica à militância característica do Cinema Novo dos anos 1960 no Brasil:

Compete a quem tiver condições captar as aspirações populares, elaborá-las sob forma de conhecimento da situação do país e reconhecimento dessas aspirações, devolvê-las então ao povo, gerando assim consciência nele. E quem tem condição de efetuar essa operação são os intelectuais. A posição social do intelectual sensível às aspirações latentes do povo lhe permite ser gerador de consciência. (...) Desse modo, a apresentação do povo como alienado explica o doloroso golpe de 64 e justifica os intelectuais, entre os quais os cineastas. A justificativa da existência do intelectual, nesse quadro, é a alienação do povo. (BERNARDET, 2003, p. 34). 
Bernardet estava com isso a mostrar que o cinema reproduzia justamente aquilo que criticava: ao explorar imagens e falas do "povo" e conduzi-las a generalizações, incluindo a de que esse mesmo "povo" era alienado, os cineastas exploravam novamente aqueles sujeitos filmados que diziam estar a lutar por melhores condições. A crítica de Bernardet é ao cineasta que criava uma voz do documentário que visava apenas provar sua tese pré-concebida sobre o Outro e o mundo. Com a chegada do som sincrônico, o falar sobre o Outro de maneira pré-concebida ficou um pouco mais difícil, para alívio de muitos cineastas, pois agora era possível gravar a voz. O modelo sociológico foi em parte deixado de lado pelas novas possibilidades tecnológicas, em parte por uma reatividade ao falar pelo Outro ou à Voz de Deus como legado.

Sobre o documentário brasileiro contemporâneo e o que predomina de produções e discursos na área, afirma Mariana da Silva (2013):

É assim que [no Brasil] o privilégio às narrativas que tomam como princípio as vidas dos sujeitos comuns, englobando aqui não apenas aqueles que são vistos, como também os que dão a ver, deriva-se em uma série de procedimentos ético-estéticos: o recrutamento da voz do outro, então considerado como capaz de elaborar por si seus modos de expressão (donde o adensamento do recurso das entrevistas e depoimentos); as formas de autorrepresentação como maneira de atestar uma autenticidade aos documentários; a ênfase na condição de dispositivo do filme, com a autorreflexividade que aponta diretamente ao caráter situado da enunciação; os investimentos ensaísticos que organizam as materialidades sonoro-imagéticas segundo uma disposição antirreferencial e sobretudo poética; o engate autoral do realizador em primeira pessoa, compondo-se como personagem dramático das deambulações do filme; as diversas modalizações da intervenção do realizador na cena.

Esse retrato do documentário brasileiro contemporâneo dominante parece um espelho refletido do modelo sociológico. É como se pegássemos tudo que pensamos sobre o modelo sociológico, colocássemos numa tabela, e completássemos uma nova tabela com o que seria o documentário em reação a isso. Parece realmente que o modelo dominante hoje no documentário brasileiro, mas também em grande parte do mundo, 
reage ao que considera ser seu passado nefasto. Uma reatividade a qualquer possibilidade de politizar radicalmente o documentário, de torná-lo um instrumento de mudança sociocultural e política. Pelo contrário, o que é dominante hoje no Brasil e outros países, é uma tendência - política, sem dúvida - de entender o documentário apenas como “arte”. Porém se entendermos que nenhuma produção cultural é apolítica, que sendo ela sempre produzida dentro de linguagens que incluem/excluem, oprimem/libertam, que toda produção cultural é feita dentro de relações de poder, e que, como mostra Esquenazi, para uma obra ser política basta que uma comunidade de interpretação assim interprete, podemos afirmar que toda obra é política, no sentido de que nenhuma produção cultural acontece num vácuo de poder e linguagem. Nenhum filme é, assim, “apenas arte.” Se, com Nichols, fôssemos dizer que "todo filme é um documentário", pois todo filme referencia o mundo de alguma forma e é interpretado com base nesse mundo, então temos que dizer também que todo filme é político, pois o mundo é feito de relações em jogo onde é impossível não se posicionar, tomar lados, fazer planos e projetos de futuro, ou esquivar-se dos efeitos de recepção de um filme. A política num filme começa no momento em que aparece a motivação de fazê-lo, pois essa motivação é sempre mediada pela cultura (fílmica, mas também política) em que o cineasta é socializado.

O “objeto” dessas práticas são significados e mensagens na forma de veículos de sinais de um tipo específico organizado, como qualquer forma de comunicação ou linguagem, através da operação de códigos dentro da cadeia sintagmática de um discurso. Os aparatos, relações e práticas de produção, assim, emitem, num determinado momento (o momento da "produção/circulação"), na forma de veículos simbólicos constituídos dentro das regras da "linguagem”. É nessa forma discursiva que ocorre a circulação do "produto”. O processo, portanto, requer, no final da produção, seus instrumentos materiais - seus "meios” - bem como seus próprios conjuntos de relações sociais (produção) - a organização e combinação de práticas dentro dos aparatos midiáticos. Mas é na forma discursiva que ocorre a circulação do produto, bem como sua distribuição para diferentes públicos. Uma vez realizado, o discurso deve então ser traduzido - transformado, novamente - em práticas sociais, se o circuito deve ser completado e eficaz. Se nenhum "significado" é tomado, não pode haver "consumo”. Se o significado não é articulado na prática, não tem efeito. O valor dessa abordagem é 
que, embora cada um dos momentos, em articulação, seja necessário para o circuito como um todo, nenhum momento pode garantir totalmente o próximo momento com o qual ele é articulado. Como cada um tem sua modalidade e condições de existência específicas, cada um pode constituir sua própria ruptura ou interrupção da "passagem de formas” em cuja continuidade depende o fluxo de produção efetiva (isto é, “reprodução”) (HALL, 2006, p. 163, tradução nossa).

Produções culturais são a um só tempo efeito e causa de discursos e práticas sociais. Se por um lado a produção de um filme precisa negociar ativamente com discursos e práticas que o antecedem, também é ela (re)produtora de outros discursos e práticas. Como aponta Hall, todo "momento" do circuito da comunicação é passível de interferências, inclusive o momento da recepção. Nesse sentido, a “verdade do filme” só pode ser o que vem a ser, ao ser consumida. E vai ser consumida de diferentes formas por diferentes públicos. Sendo assim, podemos continuar a dizer que existe a "verdade do filme” no singular? Se sua verdade é sempre múltipla e contraditória? No discurso hoje dominante sobre o documentário, e como parte dele, a “verdade do filme” é necessariamente um esquecimento da recepção - e porque esquecem da recepção? Porque há a crença, não refletida ainda, no "mundo compartilhado" de Nichols. É como se não houvessem diversidades de subjetividade, não houvessem discursos dominantes sobre o Outro - que necessariamente interferem na maneira como cada sujeito interpreta filmes e outras produções culturais. Para haver a "verdade do filme" de Coutinho e a "voz do documentário” de Nichols interpretada por ele como uma produção que parte dos cineastas, estes dois conceitos só fazem sentido num mundo interpretado como unívoco e feito apesar das interpretações possíveis. Se a tarefa do documentarista é “falar” sua “mensagem” - mesmo que a mensagem venha mais do Outro sujeito filmado - quando cineastas e pesquisadores do cinema caracterizam filmes apenas como "arte" e não como sempre inexoravelmente políticos, porque assim sempre são recebidos por alguém - estão a querer controlar o incontrolável: os modos de circulação e recepção de seus filmes. Um resultado do discurso dominante sobre o documentário brasileiro hoje, é que

De maneira mais imediata, percebemos que os enfoques particularizantes, em uma disposição microscópica em se olhar para as experiências dos personagens, como se cada um deles compusesse um 
mundo não coincidente com outros, alicerçam o ponto de vista no documentário contemporâneo. (SILVA, 2013, p. 215).

O discurso dominante no documentário brasileiro levou alguns documentaristas e pesquisadores a afirmar que "A única realidade que existe num filme é a realidade interna de um filme.” (AVELLAR, 2010, p. 145). O mundo é, na prática, fragmentado pelos filmes nesse novo modelo dominante. Contra o modelo sociológico, que é entendido como pedagógico demais, reina hoje o subjetivismo.

Os filmes que são produzidos com intuito de intervir no mundo, que trazem do mundo suas inquietações e visam com elas produzir efeitos - mesmo que múltiplos, contraditórios, incontroláveis - nesse mundo, precisam reconhecer, até para serem mais efetivos, que a realidade do mundo os atravessa. Não estamos aqui a falar de uma realidade unívoca - talvez melhor seria falarmos em realidades no plural para sermos melhor compreendidos. A linguagem é parte do mundo, e apesar de não ser transparente ou não ter uma relação de 1 para 1 com o mundo - dizer charuto não é ter ou ser o charuto, necessariamente -, o que vemos no discurso dominante sobre o documentário no Brasil hoje, é a colocação de que o documentário não fala sobre a realidade. Porque haveria de ser um Sim ou Não à relação entre documentário e realidade? Porque é que saímos do "modelo sociológico" que é caracterizado desse modo justamente por ser tachado de acreditar numa Verdade universal científica e final, para um modelo de Verdades Relativas, subjetivas, poéticas, mas ainda assim Verdades? Porque é que um filme precisa ainda, para ser valorizado, carregar uma Verdade? Porque ao filme documentário restou, assim como para outras produções culturais como a literatura, o espaço do não-político: a ficção é sempre desculpada por ser “irreal”, ou é assim tornada menos impactante?. O filme documentário pode ser mais dócil e subserviente ao status quo se ele se declara, como faz desde Flaherty, “apenas arte”. A política ficaria de fora, para o bem dos poderes estabelecidos.

Como mostra Roger Odin, no entanto, a diversidade que é operada pelas relações de poder num filme nunca fica de fora. Odin identifica ao menos três “actantes” em toda “leitura” do documentário:

- $\quad$ um filme, que demanda, mais ou menos urgentemente, mais ou menos explicitamente, ser lido segundo um ou outro modo de leitura; 
- $\quad$ uma instituição, que programa de um modo mais ou menos restritivo um ou outro modo de leitura;

- $\quad$ e um leitor, que reage à sua maneira às solicitações e instruções das duas outras instâncias.

\section{Continua Odin:}

Não é necessário que as relações entre esses três actantes sejam sempre de natureza pacífica: um filme pode ser rejeitado pela instituição na qual foi projetado, o leitor pode recusar-se a jogar o jogo demandado pelo filme ou não se dar conta das determinações que a instituição faz pesar sobre si etc.; da mesma forma, seria falso acreditar que essas relações permanecem estáveis ao longo da leitura de um filme: às vezes, o leitor se conforma à demanda do filme; às vezes, à da instituição; às vezes, ele se deixa levar a outras determinações... a menos que mobilize simultaneamente vários modos de leitura.

Odin nos ajuda a compreender que, diferentemente do estruturalismo e do positivismo funcionalista, a comunicação não se dá de maneira linear, em que o emissor emite uma mensagem ao receptor (passivo). Diferente disso, sua compreensão da comunicação seria mais pragmática (ele cunhou o termo “semiopragmática”), no sentido de que toda leitura depende de uma rede de relações instáveis, onde todos os “actantes” fazem suas leituras uns dos outros, todos com papel ativo no processo da produção das leituras, e nenhum sendo autônomo ou capaz de sozinho deter a proliferação de interpretações e reações diversas possíveis a um filme. Ou seja, o que um filme vai ser ou fazer, só as relações múltiplas que são parte tanto da produção quanto da recepção de um filme, podem nos ajudar a compreender, e nesse sentido é impossível prever totalmente ou controlar os efeitos de um filme.

Desse modo, o que um cineasta diz que faz o seu filme, é sempre apenas parte da história. E pode ser uma parte muito pequena. A recepção de filmes não está no controle do cineasta. A voz do documentário também não está. A voz do documentário é co-criada em conjunto - e no momento - da sua recepção, além de ser co-criada com a cultura dominante e reproduzi-la de alguma forma, para além de todas as intenções. Nenhuma produção cultural é feita num vácuo de cultura, ou numa universalidade da verdade. Questionar a universalidade da voz (de um Outro ou de um filme) não é questionar sua 
objetividade - pode ser questionar para que se reconheça objetiva em sua parcialidade (RIBEIRO, 2017, p. 25). Porém esse questionamento sobre um filme não se faz apenas como filme. Sendo que todo filme é contingente em sua produção, trazendo sempre consigo a parcialidade e socialização dos cineastas envolvidos, traz consigo também todas as suas zonas de não-reflexão, seus inconscientes, traz necessariamente a referencialidade do mundo vivido, pois este é sempre lido pelo público, suas contradições e embates de saber e poder. Aos conceitos da "voz do documentário" ou da "verdade do filme”, devemos indagar: Quais vozes podem ter sido silenciadas por um filme? Quais formas de opressão podem ter sido reproduzidas através do filme? Quais formas de resistência tiveram algum espaço num filme? A percepção de que todo filme reproduz de alguma forma a sociedade dentro da qual é produzido nos leva à constatação de que por mais que um filme busque ser apenas filme, nunca consegue. Pois todo filme já é feito de outras produções de uma cultura e tem efeitos sobre essas. Nenhum filme é original no sentido de que ele já é cópia - mesmo que tente rompimentos, mesmo que copie reativamente e contrariamente - da cultura fílmica ou do mundo vivido do qual provém.

\subsection{A voz do documentário revisitada}

Queremos aqui propor que o conceito de voz do documentário pode ainda ser útil a nós, se o pensarmos a partir dos estudos de recepção que apresentamos, considerando uma análise que inclua o contexto sociocultural de produções culturais como filmes. Se, como apontam os pesquisadores que citamos aqui como Hall, Fish, Esquenazi, toda produção cultural é uma criação que precisa da coletividade para ter sentido e circular realizando efeitos, se isso parte desde o momento de sua produção, circulação, até a recepção que, longe de ser passiva, é ativa e múltipla e contraditória, a voz do documentário só pode ser ouvida de forma não unívoca e fora do controle de seus produtores - cineastas, instituições, etc. As “comunidades de interpretação” (FISH, 1980) não são fixas em seu modo de interpretar e receber produções fílmicas, nem previsíveis, pois, assim como os filmes, elas também estão em contingência sociocultural, linguística, politica, em constante mudança. Como nenhuma cultura é fixa no tempo, nem se pode esperar que seja homogênea em seus modos de recepção de produções culturais, assim também a forma como se produz e se interpreta filmes muda com o tempo.

Muitas vezes, como buscamos demonstrar aqui, na história do documentário, essas mudanças acontecem de forma reativa. Se na voz do documentário, no conceito de 
Nichols, a parte preponderante dessa $v o z$ é a do cineasta, é porque ainda impera o discurso hoje dominante de que documentário é arte e não é política. E arte nesse discurso dominante é sempre relativa a um autor. Os chamados “documentários criativos” são uma criação do discurso hoje dominante sobre o documentário, onde se diz reconhecer traços de autoria num filme que seriam particulares a um autor específico. Nesse modo de conceber, a recepção não é pensada como um problema, ou como inextricavelmente definidora da $\mathrm{voz}$ do documentário. Pois o próprio cineasta não está sendo pensado como um receptor, como produtor e reprodutor de cultura, em todos os seus aspectos de opressão e de resistência que toda cultura acarreta. O paradigma em comunicação dominante aqui é o de que comunicar é “falar”, é passar uma “mensagem”, mesmo que apenas através de imagens e não de falas.

Mas os estudos culturais, pós-coloniais, o feminismo negro, entre outros legados do pensamento e cultura de nossos dias nos mostram que comunicar é se posicionar, é escolher quem precisa ser ouvido e quem não, quem precisa ter mais poder e recursos realocados para si, e quem não. Que essa é uma escolha, que pode ser ainda mais evidente quando se a evita. Pois evitar a questão da responsabilidade sobre a representação, pelo modo como ela vive no mundo e produz efeitos, reflete o privilégio de um cineasta (geralmente se é branco, de classe média ou rica, mais privilegiado e mais distante de uma reflexão sobre seus privilégios). A questão das escolhas envolvidas na produção da $\mathrm{Voz}$ do documentário partem do mundo compartilhado e vai de volta ao mundo, e nisso estamos com Nichols. Porém não está nas mãos do cineasta determinar a voz do documentário. O cineasta consegue no máximo influir. Sua cultura, sua história, toda a contingência da produção, instituições envolvidas, modos de circulação e as comunidades interpretativas que recebem o documentário, tudo isso é que influi para a criação da voz do documentário, que será sempre múltipla e contraditória. Assim, se um filme documentário tem voz, essa é sempre contingente ao mundo que a produz, reproduz, ou silencia. Essa voz sai primeiro do mundo, é transformada pela produção do filme, para retornar ao mundo e ser transformada novamente pelos receptores ativos. Essa transformação de produções culturais é política, pois envolve relações de poder que influem necessariamente nas produções e recepções possíveis.

Se a voz do documentário é sempre política, o que seria do documentário se levarmos isso a sério? Seria o bastante fazer filmes apenas para responder a outros filmes? Fazer filmes que mostram outro jeito de fazer, apenas porque se pode? O que pode o documentário? Demonstrar técnicas e jeitos de fazer, é sempre apenas uma parte 
do que se faz num filme. Não refletir sobre como um filme reflete o mundo e o (re)produz, é olhar para o filme como um ser unívoco. Se um cineasta faz isso enquanto seu Outro sujeito filmado é machista, e o cineasta lhe dá cordas para falar mais, isso vale a pena apenas para mostrar que podemos fazer as pessoas falarem? E quanto à reprodução do machismo no filme, ele vale a pena, porque afinal é “apenas arte”? A fascinação com o Outro sujeito filmado exige certo romantismo e voyeurismo, e todo romantismo diz muito mais sobre quem olha/ouve, do que sobre quem fala/vê. Porém todo romantismo é meio cego, especialmente se o cineasta é homem, ele não interpelaria seu Outro sujeito filmado sobre seu machismo, pois isso seria “julgar”. Mas o cineasta já julgou que não deveria interferir, e com isso deixou em seu filme o machismo se reproduzir na sociedade. Alguns espectadores vão rechaçar o machismo ou racismo do Outro sujeito filmado - culpando-o, julgando-o, mas, no discurso hoje dominante sobre o documentário no Brasil, raramente vão culpar ou julgar o cineasta. O mesmo discurso que protege os filmes de serem tachados de realidade, protege os cineastas de acusações sobre os efeitos de seus filmes. E muitos, claro, querem que continue assim, pois fazer filmes é uma carreira, e quanto mais uma carreira é protegida de seus efeitos, melhor para cineastas que querem “apenas” fazer filmes de “arte”. Machismo não está apenas nos olhos de quem vê, não está apenas em filmes, está no mundo. Fazer a leitura do machismo num documentário não é criá-lo; é notar que essa leitura vai ser feita, até inconscientemente, por pessoas socializadas nele.

A teórica do cinema feminista Claire Johnston afirmou:

Claramente, se aceitarmos que o cinema envolve a produção de signos, a ideia de não intervenção é pura mistificação. O signo é sempre um produto. O que a câmera de fato captura é o mundo 'natural' da ideologia dominante. O cinema das mulheres não pode permitir tal idealismo; a 'verdade' da nossa opressão não pode ser 'capturada' em celulóide com a 'inocência' da câmera: ela tem que ser construída/manufaturada. Novos significados tem que ser criados perturbando a estrutura do cinema burguês masculino no interior do texto do filme (1976, p. 214).

Muitas cineastas feministas usaram da disjunção entre som e imagem para buscar romper com representações dominantes sobre a "mulher” e o "feminino". Pois assim 
como Johnston afirma, as representações dominantes constroem como "natural" a condição subalterna da mulher. Sendo assim, operar pelas disjunções, assim como pelas justaposições poéticas entre imagens e entre imagens e sons, especialmente no cinema experimental, é um caminho que as cineastas encontraram para falar sobre as condições das mulheres num sistema patriarcal. Pois sabiam que ao operar pelas representações dominantes, pela transparência (mesmo que sempre fabricada) do cinema realista apenas, estariam reproduzindo mais do que gostariam as dominações que combatem.

As cineastas feministas como Chantal Akerman, Yvonne Rainer, Trinh T. Minhha, entre outras, usaram bastante da disjunção entre imagem e som, e da fragmentação de sequências. Seus filmes buscam ativamente romper com interpretações dominantes sobre o Outro, embora o quanto são eficazes nisso perante quais públicos seja sempre uma pergunta em aberto. A aposta das cineastas feministas é no papel ativo da recepção, na possibilidade do rompimento com representações dominantes justamente porque essa possibilidade existiria no público, por mais que seus filmes busquem também não fixar representações sobre seus sujeitos filmados. A tentativa dessas cineastas não é a de fixar a verdade sobre seus sujeitos filmados. Nesse sentido, o que elas operam é o uso do cinema como forma de uma intervenção mediadora.

A mediação é dialética, porque, embora seja perfeitamente possível privilegiar os meios de comunicação de massa como definidores e, talvez, determinantes de significados sociais, essa ênfase desconsideraria o engajamento criativo e contínuo que ouvintes e espectadores possuem com os produtos da comunicação massiva. A mediação é, também, assimétrica, precisamente porque o poder de operar com ou contra os significados dominantes ou profundamente enraizados que as mídias produzem é distribuído de modo desigual entre e nas sociedades (Silverstone in SERELLE, 2016, pp. 79-80).

A mediação, podemos afirmar, é um processo sempre atuante onde as interpretações e efeitos de produtos culturais são tanto resultado dos modos pelos quais esses produtos são feitos, sua contingência de produção envolvendo os discursos, linguagens, representações que mobilizam, quanto dos modos de engajamento de ouvintes e espectadores que trazem seus discursos, linguagens e representações para criar 
sentidos a um filme como produto cultural. Os significados e efeitos, desse modo, não são produzidos apenas pelos produtores, o são também pelos consumidores, e a linha tênue que os junta e separa ao mesmo tempo pode ser difícil ou até impossível de descrever. Um filme, ao ser assistido, toma vida própria, por mais que seus diretores e produtores tenham lhe encaminhado para certa vida mobilizada por eles. Os efeitos de um filme advém da forma como ele é produzido, mas apenas parcialmente. Suas possibilidades interpretativas e (re)produção de cultura e de ações no mundo dependem também fundamentalmente da recepção sem a qual um filme não vive, e se não vive, não produz efeitos no mundo. A questão que deve ser feita então a filmes como entes viventes do mundo que são é: quais efeitos eles (re)produzem ao circular, ao serem consumidos?

O enredamento do midiático no cotidiano se tornou fundamental para o modo como as pessoas administram suas vidas. Segundo Silverstone, a mídia fornece molduras, recursos simbólicos para que possamos nos movimentar na complexidade do cotidiano e produzir sentido a partir de suas relações intricadas. Estamos cada vez mais dependentes dela para definir nossa conduta em relação ao Outro, principalmente o outro distante, que só nos torna visível por meio do midiático (SERELLE, 2016, p. 84).

As mídias são (re)produtoras da cultura e da sociedade, e como tal, todo produto cultural midiático precisa pensar sobre seus efeitos, tanto para o Outro sujeito filmado, quanto para Outros que vão assistir filmes. Como mediador da cultura, um filme documentário tem uma responsabilidade inextricável para com o Outro, pois necessariamente influi sobre vidas, sobre o mundo vivido, quer queira ou não, pois aqui não há a escolha de não-intervenção.

Há modos do fazer cinema que vêem filmes como entes que produzem efeitos e que são pensados para tal. O cinema feminista, assim como cinema negro, indígena, queer, o cinema social e político e outros cinemas que tem sua preocupação com a representação da alteridade, seja para lutar contra legados dominantes na representação, seja para afirmar a possibilidade de vida da diferença social, todos esses buscam ser aliados dos Outros sujeitos filmados. Um cinema que busca ser aliado dos Outros, necessariamente precisa pensar em como fazer para produzir uma voz do documentário 
que seja aliada desses Outros e suas vozes. É nesta questão que nos concentramos no próximo capítulo.

\section{CAPITULO 3}

\section{Vozes no documentário}

\subsection{Jogo de vozes}

A teoria em cinema tem se centrado dominantemente na análise da imagem. Esta dominância se dá por vários motivos, entre eles: o caráter específico do cinema da imagem em movimento, que se aproxima do caráter vivencial, referencial ou indéxico de imagens (1); as possibilidades que se abrem ao rompimento desse mesmo potencial exatamente porque, sendo representação, é apenas potencial - (2) e, ainda, justamente, pela desidentificação com o referencial ou indéxico (3). Desse modo, o cinema tem um caráter duplo e ambivalente: pode aparecer como realismo, em que imagens e sons reproduzem um discurso do mundo vivido, ou pelo contrário, pode desconstruir o realismo, desafiando discursos sobre o mundo vivido e produzindo rompimentos e quebras nos discursos dominantes. Ao primeiro movimento, do discurso cinematográfico realista, Gilles Deleuze cunhou o termo Imagem-Movimento em livro homônimo, e, ao segundo, do rompimento do realismo, o termo Imagem-Tempo em outro livro. Para Deleuze, o cinema produzido pela Imagem-Tempo produz interstícios de imagem para imagem onde não se produz mais a referencialidade ao "real" mas sim ao movimento das imagens e do pensamento, onde as brechas entre imagens permitem o pensamento se desterritorializar e abrir-se para novos potenciais.

A teoria deleuziana do cinema, no entanto, não se preocupa em pensar para além das imagens, para o cinema enquanto discurso. Está preocupado apenas em demonstrar as potencialidades da orquestração das imagens de forma que a alteridade seja possível. Se ela é possível, como demonstra Deleuze, o que pode essa alteridade? Para nosso propósito aqui: O que pode a alteridade no documentário? O filme documentário, como cinema, é sempre uma montagem, uma construção, mesmo que seja “realista”. Teorias que a princípio vieram de outros campos do conhecimento hoje interpelam o cinema, bem como todas as artes, enquanto linguagem e discurso. 
A teoria pós-estruturalista nos lembra que habitamos no interior da linguagem e da representação, e que não temos acesso direto ao "real”. Mas as construções e codificações do discurso artístico não excluem referências a uma vida social comum (SHOHAT \& STAM, 2006, p. 263).

Robert Stam e Ella Shohat são dois teóricos do cinema que trouxeram as inovações do pós-estruturalismo, pós-colonialismo e feminismo para pensar o cinema enquanto produção cultural e seus efeitos de representação para os sujeitos filmados. Eles nos demonstram que o cinema é sempre feito dentro da linguagem, sendo assim opera como discurso e (re)produz jogos de verdade da cultura em que opera. Para eles,

não basta dizer que a arte implica construção. Temos que perguntar: construção para quem? E em conjunção com quais ideologias e discursos? Dessa perspectiva, a arte é uma representação não tanto em um sentido mimético, mas político, uma delegação de vozes (SHOHAT \& STAM, 2006, p. 265).

Todo discurso é uma orquestração de vozes onde algumas são dominantes e outras têm menos espaço de representação ou são mesmo silenciadas. Assim, como discurso, o cinema opera pela reprodução de algumas vozes e diminuição ou silenciamento de outras. Quanto mais uma voz é Outro em relação ao discurso dominante numa dada cultura, maior silenciamento dos Outros que operam ou vivenciam essa voz. Stam e Shohat mostram que toda representação do Outro lida necessariamente com a questão da (re)produção de estereótipos de raça, gênero, etnia, classe social, entre outros. Estereótipos são modos hegemônicos de representação do Outro que descartam ou ignoram suas possibilidades de diferença, e podem ser positivos ou negativos, podem reforçar a condição de opressão de um grupo social, ou podem impedir que os Outros falem por si mesmos, pois todo estereótipo carrega consigo um discurso dominante sobre o Outro. Um discurso que em sua dominância impede ou inibe a produção de outros discursos e diferenças. Os estereótipos, ao não serem confrontados diretamente por um filme, ou mesmo quando confrontados, podem ainda ser lidos pelo público do filme e reproduzidos. Ou seja, por mais que um filme trabalhe sobre a representação do Outro, 
buscando confrontar e romper com discursos dominantes sobre esse Outro, ainda assim os públicos podem ler um reforço do estereótipo no filme. Um mesmo filme pode ser lido como representativo de um Outro, e ao mesmo tempo ser lido como reprodutor de violências e inverdades contra esse Outro, dependendo de quem faz a leitura.

Assim, a despeito do fato de que não existe uma verdade absoluta, nenhuma verdade distante da representação e da disseminação, ainda existem verdades contingentes, qualificadas a partir de certas perspectivas, que informam a visão de mundo de certas comunidades (SHOHAT \& STAM, 2006, p. 263).

O filme documentário lida sempre com verdades contingentes. Essas têm relação com a vida de pessoas, e é a forma com que o filme lida com verdades contingentes que as faz julgar o filme como mais ou menos adequado às suas verdades arraigadas. Tanto o filme em seu todo, quanto os Outros sujeitos filmados que aparecem num filme, são julgados como mais ou menos verdadeiros em relação às contingências vividas pelo público. Essas verdades contingentes, produzidas ou não por um filme (pois podem ser as verdades carregadas do público do filme), produzem a voz do documentário ao modo como a entendemos aqui, enquanto discurso múltiplo e contraditório no ato de ser assistido e interpretado. A voz do documentário só vive e se torna o que pode ser, no ato da recepção do filme. A representação do Outro no documentário é feita através de uma narrativa, mas isso não esgota a colocação em jogo das estruturas sociais que os públicos de filmes trazem em sua representação do filme, que se chocam e entram em embate com aquilo que o cineasta buscou representar. Ao ver um negro pobre do Brasil num filme, a audiência brasileira vai trazer consigo necessariamente os estereótipos sobre esse Outro das mídias e da cultura dominante à tona. E a recepção vai variar muito conforme os públicos. Para uma audiência consumidora branca, um negro passa a representar todos os negros - ou ao menos o negro pobre. A “supremacia branca”"27 influi sobre como se dá a recepção da imagem do negro na sociedade ocidental, onde um negro (ou um indígena,

\footnotetext{
27 bell hooks (1989, p. 113) afirma que "supremacia branca” é um termo muito mais útil para entender a cumplicidade de pessoas de cor na defesa e manutenção de hierarquias raciais que não envolvem força (isto é, escravidão, apartheid) do que o termo "racismo internalizado"- termo mais usado sugerir que os negros absorveram sentimentos e atitudes negativas sobre a negritude. O termo "supremacia branca" nos permite reconhecer não apenas que os negros são socializados para incorporar os valores e atitudes da supremacia branca, mas também podemos exercer o "controle da supremacia branca' sobre outros negros”.
} 
uma mulher etc.) passa a representar toda uma comunidade, mesmo que não haja muitos indicativos para isso no filme. No Brasil, onde a grande maioria dos cineastas são brancos, se instaurou uma tradição no documentário de retratar pessoas negras, mas sem tratar da negritude na narrativa. O tratamento da negritude no documentário brasileiro colocou as

experiências de vida negras situadas sempre na tangencial de um modelo sociológico. (...)

Desta tradição inicial surgirá uma equação fílmica e didática tão falsa quanto aceita: se documentários sobre violência, pobreza - signos comuns - dizem tratar da realidade brasileira filmando pessoas negras, sem apontar a negritude como dado, naturaliza-se que signos comuns da realidade é igual pessoas negras. A equação não é falsa pelos elementos que traz, mas pelos limites que supõe (GALINDO, 2017, p. 305).

Hoje, o negro como Outro do documentário, produz seus filmes sobre a questão negra onde a negritude é referenciada em grande parte dos filmes, transformando-se a negritude em “impulso e não mais limite” (GALINDO, 2017, p. 306). Se a audiência é brasileira, branca e rica ou classe média, suas expectativas quanto à atuação e à vida do negro pobre provavelmente serão diferentes. Expectativas de que o negro pobre possa ser do crime, por exemplo, estarão presentes caso o filme mostre a favela ou dê indícios da presença da criminalidade. A essas tendências conhecidas de representação do negro e pobre no Brasil, surgem propostas de criação de imagens positivas para contrariar estereótipos. A colocação de que uma imagem é errônea, que não representa um Outro ou uma comunidade, é feita por aqueles Outros que são representados, ou por críticos. Porém, como criação de representação que são, essas também precisam refletir sobre sua própria construção e mesmo reprodução daquilo que criticam, pois a imagem positiva é pensada e produzida muitas vezes em reatividade à imagem negativa, desse modo esquivando-se de fazer o confronto com as estruturas sociais e culturais que criam a imagem negativa em primeiro lugar, desse modo individualizando condições históricas e socioculturais. A imagem positiva de uma mulher negra bem-sucedida num filme pode ter 
efeitos positivos para ajudar no confronto do racismo estrutural ${ }^{28}$, mas se apenas mostra uma história onde numa leitura dominante a mulher negra seja "vencedora pelo seu mérito individual”, o filme acaba jogando fora a oportunidade de mostrar que a individualização do mérito reproduz o racismo estrutural (ou de ao menos não reforçar uma crença que reproduz o racismo ao querer mostrar que todos seriam iguais). Há a representação do Outro, de sua vida, do mundo, e há a representatividade - se o personagem é alguém que corporifica uma identidade que pode gerar identificação de grupos do mundo vivido. Porém, a representatividade em si não é necessariamente positiva. Uma pessoa negra pode ocupar um lugar de poder e de fala, porém sua fala e sua prática ser desligada, alienada do restante da população negra - é nesse sentido que hooks aponta para o efeito da supremacia branca, de identificação do negro com a cultura branca. Nesse caso, há uma representatividade que deve ser questionada no tocante ao quanto ela ocupa um lugar de prestígio social para criar oportunidades para outros sujeitos, ou o quanto reforça dominâncias, ou o que é muito frequente, o quanto faz as duas coisas ao mesmo tempo: produz resistências e reproduz dominações, o que é muito comum acontecer com celebridades popstar. Pois filmes não apenas lidam com imagens. Filmes são discursos e são práticas sociais, tendo efeitos sobre essas. Nesse sentido, quando indígenas acusam filmes de Hollywood de racismo por conta de seus estereótipos do indígena, como no livro Fantasies of the Master Race, de Ward Churchill (1998), é porque veem que os filmes os representam de forma subalterna ou estereotipada, o que viria a reproduzir tanto o racismo quanto as estruturas que os mantém em condições subalternas numa sociedade. Em suma, ao não lidar com questões de estruturas sociais, filmes podem estar reproduzindo-as muito mais do que os seus produtores desejariam. Aquilo que não se reflete, se repete, seja porque o cineasta evita o confronto, seja porque os públicos estão prontos a reproduzir os valores e discursos dominantes, ou seja, pelos dois motivos.

Se ficarmos apenas na análise fílmica que prioriza a análise de imagens, deixamos de lado todo o campo que faz a ligação de filmes com as conjunturas sociais, culturais, linguísticas, históricas, o que poderia ser alcançado por outras análises, como a de aspectos discursivos no cinema. Podemos pensar, por um lado, que isso se dá em parte por conta do modo como o campo científico-acadêmico opera dominantemente por meio

\footnotetext{
${ }^{28}$ Em O Que É Racismo Estrutural, Silvio Almeida mostra como o racismo está ligado a processos históricos, culturais, econômicos e políticos, e que essa rede de formações tende a reproduz o racismo ao mesmo tempo que o racismo é fundamental para a manutenção do status quo do Estado, do capital e da supremacia branca, entre outros.
} 
de disciplinas científicas, e toda disciplina para se individualizar precisa definir um objeto de estudo. Dado que o cinema é o “campo" do estudo, muitos estudiosos escolheram como seu objeto as imagens. Por outro lado e em consonância a esse discurso do cinema como campo das imagens, o que sustentaria a posição das imagens enquanto objeto científico seria a singularidade das imagens no cinema, dado que antes do aparecimento do vídeo, o cinema era o único campo social onde as imagens tinham a característica do movimento. Daí, conjeturamos apenas rapidamente aqui, o cinema ter sido aos poucos discursado no meio científico-acadêmico como o campo das imagens. Seria interessante uma pesquisa específica sobre o surgimento do discurso do cinema como campo das imagens, e os discursos alternativos que ficaram de lado nessa dominância.

Diferente de Bill Nichols e sua "análise formal-social” que descrevemos no primeiro capítulo, acreditamos que uma análise de filmes que possa dar conta de seu caráter contingente deve ser uma em que esses dois aspectos, formal e social, devem ser lidos em conjunto, são inseparáveis para o que nos importa como pergunta central de nossa pesquisa: como podem ser representadas as vozes de Outros na voz do documentário, em particular dos Outros que são excluídos, oprimidos, marginalizados? Essa pergunta vem de nossa preocupação com o cinema enquanto produção cultural que tem responsabilidade sobre o modo como (re)produz relações de poder e estruturas sociais. Ela é reflexo de uma posição que é crítica aos modos de entendimento do cinema enquanto campo da “imagem”. Stam e Shohat abriram o campo para nós na teoria do cinema. Afirmam eles:

Acreditamos que uma alternativa metodológica à abordagem mimética [“realista”] dos "estereótipos e distorções” seria um enfoque nas “vozes” e “discursos”. O próprio termo "estudos da imagem” apaga o oral e a "voz" de forma sintomática. Uma predileção pelas metáforas auditivas e musicais - vozes, entonação, acento, polifonia - reflete uma mudança de foco, como sugere George Yudice, de um espaço predominantemente visual e lógico da modernidade (perspectiva, evidência empírica, domínio do olhar) para um espaço pós-moderno do vocal (etnografia oral, uma história dos povos, as narrativas escravas), de modo a restituir a voz dos excluídos. O conceito de voz sugere uma metáfora através da infiltração de fronteiras que, como o som e o cinema, remodelam a própria espacialidade, ao passo que a organização 
visual do espaço, com seus limites, cercas e policiamentos, forma uma metáfora de exclusões e arranjos hierárquicos. Não é nosso propósito simplesmente reverter as hierarquias existentes - substituir a demagogia do visual por uma nova demagogia do auditivo - mas sugerir que a voz (e o som) e a imagem podem ser considerados juntos, dialeticamente e diacriticamente. Uma discussão mais nuançada sobre a raça e a etnia no cinema deveria enfatizar menos uma adequação mimética e unívoca a verdades sociológicas ou históricas, e mais o jogo de vozes, discursos, perspectivas, incluindo aquelas que operam no interior da imagem (SHOHAT e STAM, 2006, p. 310).

A análise fílmica discursiva propõe uma leitura de filmes daquilo que eles carregam enquanto "jogo de vozes, discursos, perspectivas" (Idem) e nesse sentido eles podem remeter, para muito além do falado, ao não-falado, e às imagens mesmas enquanto enunciadoras de discursos ou enquanto silenciadoras. Particularmente no filme documentário, estamos a receber vozes e discursos de Outros, e essa recepção se dá ativamente, a partir das vozes e discursos que carregamos em nós como público - quer estejamos conscientes ou não. Como público de filmes, não somos passivos: há o gosto, há a valoração que uma pessoa faz de um filme como um todo, ou das falas dos Outros sujeitos filmados. Mas há em todos os públicos, discursos dominantes sobre Outros que os atravessam e se impõem de alguma forma, seja porque o filme remete diretamente a eles, seja porque algum jogo de vozes e discursos foi remetido pelo próprio público - que recebe assim ativamente, criando o que para este vai ser a voz do documentário que ele chega a ouvir, em parte, das vozes que carrega consigo. Mesmo que um filme evite ao máximo tipificar o Outro, a leitura que faz o consumidor do filme sempre será carregada de vozes e imagens prévias. Continuam Shohat e Stam (Idem):

Menos importante que a "acuidade mimética” do filme é sua capacidade de transmitir as vozes e perspectivas da comunidade ou comunidades em questão. Se a palavra “imagem” remete à questão do realismo mimético, "voz" invoca um realismo de delegação e interlocução, uma fala situada entre o "quem fala” e o "para quem se fala”. Se existe uma identificação com a voz/discurso de uma certa comunidade, a questão das imagens “positivas” é corretamente reduzida a uma questão subordinada. 
O pensamento pós-colonial afirma a contextualidade ou contingência de todos os discursos. Todo discurso tem uma contingência histórica e sociocultural, por mais que essa seja contestada, dado que é inerentemente político, em que todo discurso tem um discurso contrário, uma dissensão em relação à qual se produzem alteridades e identificações. Se uma dada voz é vista como legítima, ela opera o mesmo discurso - o que não quer dizer que seja idêntica com o discurso. Uma voz é recebida como discurso, isto é, como múltipla e contraditória, mas tem sua especificidade enquanto voz que é. Continuam Shohat e Stam (Ibidem, p. 311):

Pode-se objetar que uma análise das “vozes” textuais pode, no final das contas, incorrer nos mesmos problemas teóricos de uma análise centrada nas imagens. Por que seria mais fácil identificar uma "voz autêntica" do que uma "imagem autêntica”? A questão central, na nossa opinião, é abandonar a linguagem da "autenticidade” e sua ênfase na verossimilhança como um tipo de "padrão-ouro" em favor de uma linguagem de "discursos” e sua referência implícita às filiações da comunidade e à intertextualidade. Essa reformulação desafia a hegemonia do visual e da imagem ao chamar a atenção para o som, a voz, o diálogo e a língua. Uma voz, vale a pena lembrar, não coincide exatamente com um discurso, pois enquanto este último é institucional e transpessoal, a voz é personalizada, tem o acento e a entonação do autor, e constitui uma interação específica de discursos (individuais ou coletivos). A noção de voz é aberta à pluralidade; uma voz nunca é somente uma voz, mas também incorpora um discurso, pois mesmo uma voz individual é uma soma de discursos, uma polifonia de vozes. O que Bakhtin chama de "heteroglossia", afinal de contas, é somente outro nome para as contradições geradas socialmente e que constituem o sujeito como a soma de discursos e vozes conflitantes. Uma abordagem discursiva também evita as armadilhas moralistas e essencialistas embutidas na análise dos "estereótipos negativos" e “imagens positivas”. Os personagens [de ficção] não são vistos como essências unitárias, como amálgamas transformadas em entidades de carne e osso, que vivem em algum lugar "além” da diegesis, mas como “construções discursivas”. Desse modo, toda a questão é alçada a um plano sócio-ideológico e não individual ou moralista. Finalmente, a ênfase no discursivo nos permite comparar os discursos de um filme 
com outros discursos cognatos que circulam socialmente - jornalismo, literatura, noticiários, programas de televisão, discursos políticos, ensaios acadêmicos e canções.

Uma análise discursiva também pode nos alertar sobre os perigos do discurso falsamente polifônico, que marginaliza e enfraquece certas vozes para em seguida fingir um diálogo com uma entidade-fantoche já enfraquecida por diversas falsificações. O filme ou comercial televisivo no qual um em cada oito rostos é negro, por exemplo, tem mais a ver com questões demográficas apontadas pelas pesquisas de mercado e a consciência pesada do liberalismo do que com uma polifonia real, pois nesses casos a voz negra é arrancada do seu contexto e esvaziada de sua cor e entonação. A polifonia não consiste no mero aparecimento de um representante de um certo grupo, mas na criação de um arranjo textual onde a voz daquele grupo pode ser ouvida com força e ressonância. A questão não se resume ao pluralismo, mas ao conjunto múltiplo de vozes, em uma abordagem que procura cultivar e frisar as diferenças culturais enquanto suprime as desigualdades sociais.

Shohat e Stam chamam atenção para a análise discursiva como aquela que permite falar sobre o que um filme faz com as vozes de Outros sujeitos filmados, e como isso está ligado tanto a outros discursos que circulam sobre esses Outros em outras mídias, quanto a estruturas sociais que podem ser reproduzidas ou confrontadas através desses discursos pela transformação desses. Chamam atenção para o entendimento de que uma voz é polifônica quando carrega consigo uma polifonia de discursos e consegue romper com os discursos dominantes que silenciariam ou despontencializariam a voz do Outro. Demonstram que uma voz de um Outro subalterno é ouvida se consegue ressonância em sua diferença em relação ao dominante que lhe domesticaria ou silenciaria. Por fim, contra qualquer "realismo" que é hoje descartado nos estudos de cinema, trazem de volta o filme como produção cultural que tem uma vida, recolocando o mundo que atravessa o filme no modo do jogo de discursos que o atravessam. Não podemos mais dizer que “um filme é apenas um filme”, ou é “apenas arte”. Se todo filme é formado por discursos, se todo filme é lido enquanto (re)produtor de discursos, seja com efeitos de reprodução de dominâncias, seja com transformações do campo dos discursos dominantes e outros, então estamos aqui a poder novamente pensar filmes como 
parte da produção de cultura, linguagem, política e da história. O campo do discurso nos permite "mundanizar” (SAID, 1983, p. 84) os filmes novamente.

O mundo atravessa um filme como discursos e vozes. Mas a voz do Outro é ouvida em meio aos discursos? A voz do Outro pode ser ouvida na voz do documentário? O que seria necessário para que a voz do Outro consiga essa ressonância num filme documentário? Certo de que não há uma receita de bolo para isso, buscaremos responder essa pergunta no que se segue, em caminhos múltiplos e sem esgotar o assunto, que é uma questão da prática da produção e da vida de cada filme, portanto imprevisível na prática e teoricamente inesgotável.

\subsection{A voz do documentário como instrumento}

Já discutimos, nos capítulos anteriores, como no documentário houve um legado dominante onde a $\mathrm{VOz}$ do documentário era formulada e praticada como unívoca, passando uma “mensagem”. Ainda nos dias atuais esse discurso é um dos dominantes, apesar de ter ele mesmo ajudado a gerar seu contrário, o discurso da "verdade do filme" que, reativamente nega seu contrário e gera a si próprio dessa forma reativa. Se antes, com o “modelo sociológico” o documentário, em tom realista, buscava interferir no mundo social-cultural-histórico, com o modelo da "verdade do filme” esse legado foi abandonado em nome da "arte” e das representações fragmentadas e subjetivistas. O cineasta da "verdade do filme" não se preocupa com as interpretações e feitos do filme enquanto intervenção no mundo, na vida de pessoas, pois acredita que o que o filme faz é criar um "momento" único que será julgado e terá efeitos apenas como esse "momento". Desligando o filme de todas as suas ligações materiais e imateriais com a cultura dominante onde é produzido e onde é recebido, o cineasta da "verdade do filme” opera com o filme como seu fim em si mesmo. Muito diferente do legado do "modelo sociológico" onde o fim era o efeito que o filme teria no mundo, mesmo que fosse para um mundo muito particular como uma instituição, região, comunidade ou grupo específico. Saímos da dominância do filme como instrumento de intervenção, para a dominância do filme como um fim em si mesmo.

Nessa passagem, criaram-se discursos sobre o porquê da valorização da "verdade do filme” e da desvalorização, ambas relativas a quem fala, do "modelo sociológico”. A produção dos filmes é ela mesma parte da produção de discursos sobre filmes e o que eles podem, ou não, fazer. Na crítica ao "realismo" no documentário, o discurso hoje 
dominante no Brasil e outros países levou essa crítica ao extremo de descartar a importância do filme enquanto prática coletiva de uma sociedade e cultura a modo de livrar-se "modelo sociológico". É como se, ao buscar por alternativas ao legado da univocidade dos filmes "pedagógicos", torne impossível falar do mundo vivido por Outros sujeitos filmados. Assim como aconteceu com a teoria pós-moderna, em que consideramos que o Outro e o Self passam a não ter uma essência unívoca e, dependendo de quem se fala, uma essência que pode ser lida como universal ou como não-essência, na teoria do cinema o questionamento sobre a possibilidade de se ouvir a voz do Outro num filme foi respondido dominantemente com um grande “Não!” e, desse modo, a valorização de filmes que incluem essa perspectiva deu-se concomitantemente. Junto disso, a desvalorização de filmes que têm na voz do Outro - particularmente aqueles que buscam representar essa voz como destoante do dominante e exigindo representatividade, espaço de poder e visibilidade, lugar de fala, realocação de recursos e mudanças sociais específicas - são ao mesmo tempo desvalorizados enquanto "pedagógicos” demais, pois politizados demais para o novo discurso dominante sobre o documentário no Brasil enquanto “arte” despolitizada. A política das imagens no documentário, assim como na teoria dominante do documentário no Brasil, é a da voz do Outro como necessariamente apolítica, sendo valorizada apenas como a "verdade do filme” e só muito pouco ou nada como “verdade do mundo”. Esse discurso dominante, como já mostramos no capítulo anterior, veio através de uma sobrevalorização da teoria sobre o documentário e seus efeitos sobre o campo, teoria essa que exigiu que o documentário deixasse para trás seu passado "sociológico" e, com isso, deixasse de dar testemunhos sobre o mundo, seus problemas e soluções. Embora, na prática, os documentários realizados em diferentes partes do mundo ainda sejam feitos em grande parte sobre uma preocupação em intervir no mundo, as tendências de um recuo e distanciamento de qualquer tentativa de intervenção são notáveis. Sobre o tipo de documentário valorizado hoje no Brasil, Marcius Freire afirma em relação a A Pessoa é Para o que Nasce (Direção Roberto Berliner, 2005), que retrata a vida de três irmãs com deficiência visual, num filme onde praticamente todas as cenas são criadas para a câmera:

Em A Pessoa é Para o que Nasce os personagens são apenas peças de situações criadas para a câmera, situações essas que não tem outro objetivo que não elas próprias. As três irmãs se dão em espetáculo para a câmera, nada mais que isso. 
Está se tornando cada vez mais comum a realização de documentários cujo objetivo se situa muito mais na mobilização do aparato que vai lhe dar forma, na estratégia de organização do mundo histórico a ser registrado e no apelo a outros suportes de imagem e som, como a internet, durante sua realização, do que propriamente em dar a conhecer, em levar o espectador a ter contato e penetrar mais profundamente na realidade do "outro".

Estamos bem longe de Jean Rouch! Não se trata aqui, como nos seus filmes, de filmar a ficção engendrada por seus personagens como se filmasse o mundo histórico, mas de filmar a ficção criada pelo diretor como se fosse, efetivamente, um filme de ficção. Essa é a grande diferença. Não há, como dizia Chris Marker, uma "verdade no caminho”, não há, como diz Jean Rouch, a “verdade do filme”. Nesse filme, há apenas um exercício explícito de voyeurismo, voyeurismo esse que culmina com a cena em que as três irmãs tiram a roupa e entram no mar, numa das últimas sequências do filme que resume o seu espírito e objetivo: o espetáculo. E, como dizia Guy Debord, “o espetáculo não deseja chegar a nada que não seja ele mesmo" (DEBORD, 1997, p. 17).

Aqui, não estamos a estabelecer que haja um “retorno” ao “modelo sociológico”, pois todo retorno na história é apenas imaginário, pois sempre apenas parcialmente possível. Longe disso. O que estamos apontando é que, enquanto discurso, nenhum filme escapa de carregar efeitos no mundo vivido, efeitos sobre a (re)produção dos modos de representação de Outros sempre estão presentes. A busca seria, então, por escolher Outros para representar entre os que queiram e precisem dessa representação, nem que seja como co-criadores da voz do documentário. Pois a voz do Outro, como discurso que é, não precisa necessariamente estar em primeira pessoa num filme para que esteja presente. Como discurso, o Outro quando fala para a câmera está sempre presente.

Enquanto discurso, a voz do documentário pode ser o espaço de inserção da voz do Outro sem que ele precise ser um sujeito filmado. Quem garante que a voz do Outro pode estar presente na voz do documentário para além dos discursos dominantes, como voz que busca efeitos no mundo? Se houvesse garantias, teríamos um manual para isso e não teríamos que teorizar e repensar continuamente, avaliar continuamente, a vida do filme, sua recepção e o quão alinhada ela está com os efeitos pretendidos pelos Outros 
cujas vozes são orquestradas pela voz do documentário. A questão que deve ser respondida sobre qualquer documentário é: qual o objetivo desse filme? Como as vozes de Outros compõem esses objetivos, e qual o poder de orquestração que tem os Outros sujeitos filmados na produção da $v o z$ do documentário? Lembrando que toda $v o z$ do documentário é ouvida conforme a contingência específica de seus públicos consumidores, as decisões sobre caminhos da representação que incluem o quê filmar, como filmar, como montar e qual o nível de atuação do Outro sujeito filmado nesse processo enquanto produtor capacitado para articular sua representação e seus efeitos possíveis, tudo isso influi para que tenhamos mais ou menos possibilidade de auto-gestão pelo Outro sujeito filmado de sua própria representação.

Quando o Outro filmado é também o cineasta, essas questões recaem sobre a mesma pessoa. Mas enquanto produtor de discurso, então essa mesma pessoa precisa se ver como (re)produtora de uma coletividade, então também nesse caso o cineasta não enxergar como é (re)produtor de dominâncias, opressões e resistências, é deixar os efeitos de seu filme à mercê das circunstâncias, é uma certa irresponsabilidade para com os Outros que serão necessariamente projetados junto com o cineasta nas telas no momento do consumo. Mas por contingências ou posições politicamente estabelecidas nossas, queremos aqui priorizar outras circunstâncias, que não são as do cineasta que filma a si próprio como seu Outro particular - por mais que não consiga se desvencilhar do mundo e seus efeitos no mundo. Nossa questão prioritária é como pensar a produção do documentário quando cineasta(s) e Outro(s) sujeito(s) filmado(s) são aliados, portanto não são a mesma pessoa. Queremos pensar a produção de filmes onde uma relação ética se estabelece entre cineasta e Outros. Pois quando o cineasta é também o sujeito filmado, há uma relação ética a menos, o trabalho é descomplicado dessa forma, portanto teríamos menos a pensar, a dizer sobre essa relação de si para si. Aliados não são pessoas que se encontram ao acaso, apesar de poderem estes se tornar aliados depois. Ao falar sobre o Aliado, estamos falando de uma relação específica cineasta-sujeito filmado.

\subsection{O aliado no documentário}

Escolhemos um Outro para falar sobre a questão da sua voz. Ao invés de escolhermos um Outro muito particular, com nome e endereço, optamos por uma categoria de Outro sujeito filmado. Daremos o nome a ele de Aliado. Por que definimos esse Outro como Aliado? Primeiro, por uma questão prática: se dizemos que esse Outro 
sujeito filmado seria Aliado, temos agora que definir o que seria um Aliado, ou como se pode construir um filme com um Outro como Aliado. Politicamente e praticamente, esse é o Outro que escolhemos como posicionamento frente à produção de documentários, é uma escolha entre outras possíveis, mas que precisa de um pensamento mais rigoroso, porque as complicações são maiores.

O Aliado, em primeiro lugar, não é um inimigo, muito pelo contrário. Somente por esse simples fato, o cineasta precisa estar atento à sua responsabilidade na representação da voz desse Aliado. A um inimigo, a questão da responsabilidade seria muito diversa, e não queremos nos deter sobre essa aqui, pois importa para nós pensar a produção de filmes que visam construir vidas melhores e não destruir um inimigo como o objetivo central. O enfoque sobre o inimigo não é necessariamente mal em si, pode inclusive trazer perspectivas importantes para a melhoria da vida, mas pensamos que um filme sem aliados vira um filme denúncia que, novamente, tem o seu valor, mas pensando a questão da voz como central ao documentário, e essa voz sendo a defesa de modelos de viver, o documentário encontraria seu ponto de inflexão na vida de pessoas específicas se encontrar ao menos uma voz à qual se alia, e não somente um inimigo ao qual se opõe. Quando um documentarista encontra um inimigo e não quer se opor a ele, acaba enaltecendo-o de certa forma, é por isso que Eduardo Coutinho, após fazer o filme Theodorico, Imperador do Sertão, nunca mais repetiu o feito de deixar falar uma pessoa poderosa, que tem poder político e o exerce sobre outros a marginalizá-los e no filme se expõe em suas crenças e atitudes autoritárias. Um filme, se não se ocupa de desconstruir um inimigo, pode lhe dar mais empatia do que talvez esse mereça. Ao não trazer as vozes dos Outros que são oprimidos, um filme apenas garante a reprodução dos discursos dominantes.

Filmes documentários podem ser muito críticos de um inimigo, como faz Michael Moore em seus filmes Tiros em Columbine (2002), no qual a National Rifle Association é sua inimiga ou Roger \& Me (1989), em que o presidente da General Motors é seu inimigo. Mas Moore, ao não escolher aliados para seus filmes, estes viram a história de uma batalha do cineasta-personagem contra os monstros, embora haja aliados que fazem a mesma crítica todos os dias e que não são procurados pelo cineasta que aparece como herói solitário. Vários movimentos e organizações que militam contra as armas e todo um movimento organizado da população afetada pela General Motors são ignoradas em seu papel pelos filmes de Moore. Um filme sem aliados aliena e perde a chance de fazer vozes ressoarem. Parece que, na ânsia de fazer filmes engajados divertidos que por isso e 
pelo fato de criar um herói rendem muito em bilheteria, deixou-se de lado as pessoas que todos os dias dizem as mesmas coisas que Moore, talvez até de modo mais radical e politizado, em favor do filme como espetáculo. O documentário engajado em causas é muitas vezes capaz de circular amplamente, pois é espetáculo de um herói solitário que ri de si mesmo. Pela sua ausência de vínculos com grupos e comunidades organizadas politicamente, mais sua não-seriedade, sua crítica se torna também alienada e solitária, fadada a ser não muito mais que entretenimento que rende muito dinheiro algumas vezes aos seus produtores.

Mas, o que seria um Aliado? Se um cineasta considera que o Outro sujeito filmado é um Aliado, em primeiro lugar sua aliança está no compartilhamento de posições sobre determinados assuntos e no acordo sobre o modo de proceder sobre esses assuntos. E esse acordo, é feito com pessoas. Não com causas. Um Aliado não faz apenas o que acha melhor, nem faz apenas pela “arte”. Um Aliado não faz o trabalho pelo Outro: o que é feito é tão importante quanto o modo como é feito. Assim, se o sujeito filmado e o cineasta são aliados, as decisões sobre como fazer um filme, o que é esse filme, e como ele deve circular e produzir efeitos, são partilhadas também. O cineasta Aliado e o Outro sujeito filmado Aliado partilham das decisões sobre a representação e seus efeitos. Pois se por um lado o cineasta entende de filmes e precisa buscar entender sobre assuntos políticos e socioculturais que são vivenciados pelo Outro filmado, de outra parte o Outro precisa estar capacitado com a ajuda do cineasta e outros para decidir sobre sua representação, pois seus efeitos recairão muito provavelmente sobre o Outro sujeito filmado. Além disso, o Outro é quem vivencia as estruturas sociais e opressões que moldam ao menos parcialmente sua vida. O cineasta enquanto Aliado precisa saber respeitar os limites de suas decisões sobre a vida do Outro.

O cineasta precisa reconhecer seus privilégios em relação ao Outro filmado, particularmente se os dois não fazem parte da mesma classe, raça, gênero, etnia etc. Não tendo passado pelas mesmas vivências, provavelmente os juízos de valor da representação serão diferentes entre cineasta e Outro filmado. Ao buscar ser Aliado, o cineasta precisa reconhecer que a vivência específica do Outro o qualifica melhor para identificar questões de opressão estrutural em suas várias formas como o racismo, sexismo, e suas posições de sujeito dentro da estrutura social. Essa característica de ouvir a experiência do Outro é forte no documentário, porém também é flagrante o nãoreconhecimento das assimetrias da parte do cineasta, que muitas vezes busca ativamente elidir qualquer referência a singularidades de seus Outros sujeitos filmados, por mais 
aparentes que sejam, ajudando assim a invisibilizar as estruturas sociais que reproduzem opressões. Desse modo, filmes que são cegos ou surdos para estruturas sociais reproduzem-nas também de maneira cega e surda. O cineasta Aliado busca sempre entender as opressões estruturais que moldam a vida do Outro sujeito filmado, inclusive buscando a visão desse Outro sobre essas questões que possam estar intervindo para suas contingências e possibilidades de vida.

O cineasta aliado precisa em primeiro lugar sempre buscar se autoconhecer. Precisa conhecer sua cultura e legados dominantes de pensamento e de prática que vivenciou em sua vida, os quais o afetaram. Precisam conhecer ao máximo possível o seu inconsciente cultural. Para não projetar suas visões de mundo sobre o Outro. Isso, é claro, é uma tarefa sem fim. Pois não há subjetividade que não carregue bias cultural, sendo toda subjetividade um processo em construção durante a vida de um indivíduo, um processo produzido em relações de poder e saber que Foucault chamou de “subjetivação”29 justamente por ser algo que não é fixo de uma vez por todas. Os legados de pensamento sobre o mundo e sobre Outros produzem sujeitos, e com eles preconcepções sobre o Outro e sobre o mundo que o cineasta precisa analisar não somente em si mesmo para não projetar sobre o Outro o que não pertence ao Outro, mas também para antecipar as projeções feitas por espectadores sobre o Outro na tela do filme. Todo produtor e espectador de filmes carrega consigo teorias sociais, discursos, mas mais importante que confrontar teorias e discursos sobre o Outro e sobre o mundo, é ver como na prática se dão efeitos de teorias e discursos. Um discurso sobre um Outro indígena como fazendo parte da natureza e sendo assim romantizado, também na prática reproduz a possibilidade do governo desse Outro indígena pelo Estado, já que esse Outro seria incapaz da cultura e portanto de governar a si mesmo. Esse efeito do discurso sobre o Outro indígena - como se fosse um Outro unívoco, “O índio” universal - corre ao mesmo tempo em que outros efeitos como o do respeito aos povos indígenas justamente por ser mais próximo da natureza. O mesmo termo, natureza, funciona tanto para reduzir o Outro quanto para elevá-lo numa romantização, dependendo do discurso posto em prática. O efeito prático do discurso sobre o Outro indígena é dessa forma múltiplo e contraditório, e cabe analisar caso a caso o que está imperando quando se considera o Outro como natural.

\footnotetext{
29 Foucault fornece com sua obra a possibilidade de uma história da subjetividade, a abertura da discussão da subjetividade não como estável ou unitária, mas como sempre constituída e em formação pelo meio social, cultural e político. Essa compreensão da subjetividade como um processo contínuo, Foucault denomina subjetivação (ver FOUCAULT, 2012).
} 
O cineasta como Aliado não fala pelo Outro. O cineasta fala em seu papel de Aliado, de seu "lugar de fala” (RIBEIRO, 2017) que é sempre situado em relação a como as diferentes dominações e resistências são vivenciadas por quem fala. Um cineasta branco brasileiro não tem a mesma vivência de outro que é negro quando o assunto é racismo. Parte-se do princípio ético aqui que para falar sobre como o racismo afeta uma pessoa em específico, ou como afeta todo um grupo, a narração dessa vivência é muito diferente entre quem é alvo de racismo e quem não o vivencia cotidianamente da mesma forma. Como Aliado, o cineasta pode falar - inclusive pela voz do documentário, mas não deve tomar crédito por algo que seus Outros sujeitos filmados já falam sobre suas condições. Ele deve ajudar a provocar ressonância, e essa se dá quando os estereótipos, preconceitos, estigmas, e inverdades sobre os Outros sujeitos filmados são encarados pelo filme de frente. Encarando os discursos dominantes sobre o Outro de frente, é que o cineasta tomando suas decisões de representação junto ao Outro sujeito filmado pode daí ajudar a abrir espaços para que o Outro possa de algum modo ser ouvido. Não há perfeição no trabalho do Aliado, e a medida do acerto ou erro é tanto o Outro sujeito filmado com o seu apoio ao trabalho do cineasta consciente dos efeitos da representação, quanto os efeitos que tem a representação após a circulação e consumo do filme. O cineasta Aliado precisa sempre reavaliar junto com o Outro sujeito filmado sobre os efeitos da representação, pois estes podem mudar. Como Aliado, o que importa ao cineasta são os efeitos do filme no mundo vivido pelo Outro sujeito filmado e suas comunidades. Linda Alcoff partilha dessa primazia dos efeitos na questão do falar com/sobre/pelo Outro:

Falar deve sempre levar consigo uma responsabilidade e responsabilidade pelo que se diz. A quem se é responsável é uma escolha política / epistemológica contestável, contingente e, como diz Donna Haraway, construída através do processo de ação discursiva. O que isso implica na prática é um compromisso sério de permanecer aberto a críticas e de tentar ativamente, com atenção e sensibilidade "ouvir" a crítica (entender). Um rápido impulso para rejeitar as críticas deve tornar a pessoa cautelosa. (4) Aqui está o meu ponto central. Para avaliar tentativas de falar pelos outros em instâncias particulares, precisamos analisar os efeitos prováveis ou reais das palavras no contexto discursivo e material. Não se pode simplesmente olhar a localização do orador ou suas credenciais para falar; nem se pode olhar 
apenas para o conteúdo proposicional do discurso; é preciso também olhar para onde o discurso vai e o que ele faz lá. Olhar meramente para o conteúdo de um conjunto de afirmações sem olhar para seus efeitos não pode produzir uma avaliação adequada ou mesmo significativa disso, e isso ocorre em parte porque a noção de um conteúdo separado dos efeitos não se sustenta. O conteúdo da afirmação, ou seu significado, surge na interação entre palavras e ouvintes dentro de uma situação histórica muito específica. Diante disso, temos que prestar muita atenção ao arranjo discursivo, a fim de compreender o significado completo de qualquer evento discursivo dado. Por exemplo, em uma situação em que uma pessoa do Primeiro Mundo bem-intencionada está falando por uma pessoa ou grupo no Terceiro Mundo, o próprio arranjo discursivo pode reinscrever a visão da "hierarquia das civilizações" onde os EUA aterrissam diretamente no topo. Esse efeito ocorre porque o falante é posicionado como autoritário e empoderado, como sujeito bem informado, enquanto o grupo no Terceiro Mundo é reduzido, simplesmente por causa da estrutura da prática falante, a um objeto e uma vítima que devem ser defendidos de longe. Embora o falante possa estar tentando melhorar materialmente a situação de algum grupo menos privilegiado, um dos efeitos de seu discurso é reforçar as concepções racistas e imperialistas e talvez também silenciar a própria capacidade do grupo menos privilegiado de falar e ser ouvido. Isso nos mostra por que é tão importante reconceitualizar o discurso, como Foucault recomenda, como um evento, que inclui orador, palavras, ouvintes, localização, linguagem e assim por diante.

Todas essas avaliações produzidas desta maneira serão necessariamente indexadas. Ou seja, eles serão obtidos para um local muito específico e não podem ser considerados como universais. Isso simplesmente decorre do fato de que as avaliações se basearão nos elementos específicos do contexto discursivo histórico, na localização dos falantes e ouvintes e assim por diante. Quando algum desses elementos é alterado, uma nova avaliação é solicitada. Nossa capacidade de avaliar os efeitos de um dado evento discursivo é limitada; nossa capacidade de prever esses efeitos é ainda mais difícil. Quando o significado é plural e diferido, nunca podemos esperar conhecer a totalidade dos efeitos. Ainda assim, podemos conhecer alguns dos efeitos que nosso discurso gera: eu posso descobrir, por exemplo, que as pessoas pelas quais eu 
falei estão zangadas por eu ter feito isso ou apreciado. Ao aprender o máximo possível sobre o contexto da recepção, posso aumentar minha capacidade de discernir pelo menos alguns dos possíveis efeitos. Esse mandado incorpora uma abordagem mais dialógica do discurso, que inclui o aprendizado de e sobre os domínios do discurso que minhas palavras afetarão (ALCOFF, 1991, p. 25).

Ser Aliado é perceber que o Outro pode estar numa assimetria em relação à linguagem e discursos dominantes, que por vezes o coloca como o Outro do Outro, como aponta Djamila Ribeiro sobre a questão da mulher negra. Pois se, com Simone de Beauvoir, aprendemos que a mulher é o Outro em relação ao homem, e tomada como secundária no discurso dominante, pois o Outro é sempre o negativo do Self/Homem, então a mulher negra, que sofre uma dupla opressão por ser mulher e por ser negra, se apresenta como o Outro do Outro (RIBEIRO, 2017, p. 38). A mulher negra também é Outro do Outro em relação ao homem negro, já que esse ao menos tem como marcação o fato de ser reconhecido como homem e portanto certo privilégio em relação à mulher negra. Essa condição faz com que a voz do Outro do Outro seja mais difícil ainda de ser ouvida. E o que quer dizer ser ouvida, para a feminista negra? Afirma Djamila Ribeiro: “A reflexão fundamental a ser feita é perceber que, quando pessoas negras estão reivindicando o direito a ter voz, elas estão reivindicando o direito à própria vida.” (Idem., p. 43). O movimento negro hoje no Brasil, em especial onde estão presentes as feministas negras, é um espaço interessante e importante de contestação dos valores e estruturas opressoras de nossa sociedade.

Uma característica interessante de muitas feministas negras é que elas não se restringem a se pensar somente como teóricas, mas como ativistas, militantes. Feminismo negro, segundo Sebastião, seria um movimento político, intelectual, e de construção teórica de mulheres negras que estão envolvidas no combate às desigualdades para promover uma mudança social de fato; não seriam mulheres preocupadas somente com as opressões que lhe atingem, mulheres negras estariam discutindo e disputando projetos. (Idem, p. 49). 
Uma característica do movimento de feministas negras apontado por Ribeiro, que também podemos encontrar em outros movimentos, é justamente que não se trata de defender identidades fixas no tempo, não se trata apenas de uma defesa do pluralismo essencialista, e sim de disputar e buscar novas possibilidades de vida, para todos. Os movimentos que priorizam a vida prática sobre a identidade, enxergam que há sempre “linhas de conexão e de desconexão" (McROBBIE, 2006, p. 531) entre identidades e projetos, e que o que podemos nos tornar deve estar sempre em contestação. Um bom Aliado das pessoas em condição de subalternidade precisa estar atento a como essas pessoas discutem suas condições, particularmente olhando para aquelas pessoas mais engajadas no entendimento de suas condições. Longe de qualquer romantismo sobre o Outro, é preciso atentar para o que dizem os intelectuais e ativistas de um dado grupo com o qual se quer trabalhar. Se alguém vai trabalhar com uma população negra, o que dizem os intelectuais e ativistas negros sobre as condições dessa população? Se vai trabalhar com uma população indígena, o que dizem os intelectuais e lideranças indígenas? Isso não quer dizer que a voz do Outro é unívoca. Mas como Aliado, o cineasta precisa ouvir várias vozes do universo cultural e político com o qual trabalha, para poder ouvir também melhor o Outro sujeito filmado, para saber inclusive como pode escutar melhor. O cineasta Aliado não tem a vivência do Outro, mas pode perscrutar sobre os discursos e estruturas sociais dominantes que afetam a vida do Outro, bem como interferem na sua possibilidade de ser escutado. Ao invés de individualizar a voz do Outro, como Aliados devemos perceber como é que o Outro opera discursos que terão efeitos sobre a vida dele mesmo e de Outros. E que somente o Outro pode ter sua vivência e, portanto, desenvolver uma fala sobre a “experiência” de ser o que é. Longe de qualquer romantismo e de achar que o Outro tem todas as respostas para si, a tarefa do cineasta Aliado é buscar mapear os terrenos de discursos e práticas que afetam o Outro, junto com o Outro. Pode ser um caminho de aprendizado de duas mãos, ou mais mãos, entre cineastas e sujeitos filmados. Ao cineasta Aliado cabe não silenciar sobre questões de opressão, apontá-las, mas sua medida para isso não é sua inteligência e sim o Outro e sua voz e as comunidades de prática as quais pertence o Outro e suas vozes. A sua medida também não é sua noção de "realidade”. Não se trata aqui de fazer apenas aqueles filmes onde o Outro fala em meio a vozes de "especialistas" que o legitimam. Porém, trata-se de concluir que o cineasta Aliado não pode ignorar as vozes dos especialistas, especialmente aqueles que fazem parte de grupos do Outro sujeito filmado, pois ao não buscar mapear os discursos e práticas dominantes, pode reproduzi-las sem o saber. 
Stam e Shohat propuseram um modo diferente de lidar com a questão do realismo. Pois muitas vezes precisamos de um discurso realista para sermos ouvidos, e isso não se dá somente em casos de disputas jurídico-legais, mas também pelo contexto e contingências que formam a comunidade ou audiência receptora de filmes. Shohat e Stam propõem que se faça a distinção entre "realismo como objetivo" e "realismo como um estilo ou constelação de estratégias que têm o objetivo de produzir um 'efeito de realidade' ilusionista”. Explicam que “o realismo como objetivo é perfeitamente compatível com um estilo reflexivo” (SHOHAT \& STAM, 2006, p. 264). Assim, um filme pode se utilizar do realismo como estilo e ao mesmo tempo ter momentos reflexivos, de quebra de um realismo da transparência, com auto-reflexões dos sujeitos e cineastas sobre o filme que estão a fazer, por exemplo. Já o realismo como "estilo ou construção de estratégias” pode ser usado como forma de ancorar o que se quer dizer num discurso do real, seja para afirmar a voz do Outro ou a voz do documentário como imanentes ao real e tendo que ser ouvidas dessa forma, seja para buscar efeitos do discurso do real junto ao público do filme. Em todo caso, o uso do realismo pode ser decidido como necessário seja pelo cineasta ou pelo Outro sujeito filmado, ou pelos dois, como estratégia de produção de efeitos sobre públicos específicos. O realismo, assim como um modo pedagógico ou didático de produção de discurso pode ser necessário para a produção de um discurso apropriado às necessidades de intervenção de um filme. Isso porque se coloca os efeitos do filme em situações específicas do mundo vivido pelo Outro como mais importantes que o alinhamento a uma filosofia do cinema em particular. Quando o que importa mais são os efeitos do filme na vida de Outros, mais do que sua adequação ou não a um real, o próprio real é produzido como estratégia de intervenção discursiva visando efeitos, mesmo que não haja nunca uma garantia plena de que a recepção do filme é idêntica àquela visada por seus criadores.

Nesse ponto, temos que pensar a própria criação de filmes, o processo em que entram cineasta e Outros sujeitos filmados, em produção. Se por um lado colocamos que para visar a afirmação da voz do Outro, o cineasta precisa se tornar Aliado e se colocar em processo como Aliado, por outro ainda estamos falando de um processo onde o cineasta pode estar com todo o controle da produção em suas mãos, e não nas mãos do Outro sujeito filmado. Ainda estamos aqui no processo onde a voz do documentário é produzida pelo cineasta, por mais que, como Aliado, este busque centrar toda a produção em torno da voz do Outro e agir para que os efeitos pretendidos em acordo com o Outro sejam a meta a alcançar. Mas há outra maneira de fazer, não necessariamente melhor, que 
seria pela co-criação de um filme entre cineasta e Outro sujeito filmado. Nesse modo, podemos ter a participação do Outro em apenas algumas fases do processo de criação e produção, ou no processo todo. Hoje em dia, crescem as produções de documentários interativos, muitos que trazem o público também para dentro da criação da montagem ou narrativa de um filme. Novamente, não há nunca garantias dos efeitos desejados por um filme, seja como intervenção, seja como outras formas de ação social, sejam alcançados. E medida para resultados sociais, políticos ou históricos de um filme não existe, ela é criada para cada projeto e seus objetivos específicos, mas quando falamos da recepção, falamos em não ter garantias do modo de recepção. Os novos documentários interativos já partem dessa premissa da pluralidade da recepção. A questão para o futuro será avaliar o quanto esse novo modo de produzir pode abrir ou fechar possibilidades de ressonância das vozes de Outros sujeitos filmados.

Nos últimos anos diversas organizações de financiamento de documentários definiram programas e fundos para filmes que visam “impacto”. Uma “campanha de impacto" vai além da produção e distribuição do filme, exigindo mais da equipe e possivelmente também dos personagens do filme. Pois o filme numa campanha de impacto é um meio para atingir objetivos que são práticos, tais como a mudança de leis, a mobilização de pessoas e instituições, até a mudança de modos de agir por pessoas e instituições. Na campanha de impacto há pessoas a mais na equipe ligada ao filme que fazem esse trabalho, buscando parcerias e realizando eventos, e ações, em que cineasta e personagens do filme podem estar envolvidos ativamente. A dificuldade de avaliar o impacto de um filme continua a mesma, pois ainda que com mais ações acontecendo diretamente pelo envolvimento da equipe ligada ao filme, como medir o impacto de um filme na sociedade continua sempre uma questão a ser reavaliada, já que em grande parte dos casos não se podem estabelecer relações causais. Novamente, a medida parte de quem? No caso de filmes que buscam se aliar a Outros marginalizados ou oprimidos, quem define os objetivos da campanha de impacto? O Outro sujeito filmado ou a equipe produtora do filme e da campanha de impacto? O discurso utilizado pelas organizações que lançaram a proposta de campanhas de impacto é de que os cineastas fazem bons filmes, e que uma campanha de impacto ajuda a ter mais efeitos. O que pouco se questiona é o que faz de um filme um "bom filme”? Quem avalia? O Outro sujeito filmado está sendo parte dessa avaliação? Tem-se como dado, algo que não é. O Outro sujeito filmado é raramente parte da criação de projetos de filme, portanto realizar impacto com um filme que sai do espaço da representação que não é partilhada, onde o 
Outro sujeito filmado tem pouca participação, é realizar o impacto a partir da visão e voz do documentário criada pelo cineasta.

As propostas das organizações proponentes e financiadoras de campanhas de impacto, tais como Doc Society e Fledgling Fund, foram analisados por Bill Nichols, e ele levanta uma questão importante sobre o discurso do “impacto":

Tal modelo também omite qualquer noção de resistência, qualquer ideia de que os espectadores, ou cidadãos, possam ter um profundo investimento no status quo que não é tão facilmente liberado. O que aconteceu com o trabalho de Stuart Hall e outros proponentes dos estudos culturais, com ênfase nas formas complexas pelas quais os filmes, a televisão e outros produtos culturais são recebidos, usados, transformados, endossados e combatidos? Os defensores do impacto social podem se envolver com os espectadores em um nível comparável de sofisticação? Ou eles simplesmente precisam fazer filmes como “componentes de campanhas estratégicas com agendas específicas”, como se o jargão piegas pudesse fazer o trabalho anteriormente reservado para ferramentas analíticas, interpretativas e organizacionais (NICHOLS, 2016, p. 213, tradução nossa).

A crítica de Nichols é de que um filme sozinho não cria impacto, pelo menos não no nível exigido para mudanças sociais profundas e transformadoras. Se um filme não é a origem das ações transformadoras, ele precisa ser pensado como meio, como apenas mais um instrumento em ações maiores que precisam ter base social, precisam ter origem fora do filme. Porém, nos discursos sobre “impacto” do documentário, o que impera é o que Nichols aponta: uma crença de que o filme possa ser a origem da mudança social, e que a recepção se dá de forma que a mudança social por meio do filme é mensurável. Se acontecem mudanças sociais, é porque há bases e movimentos sociais para fazê-lo, o que um filme pode fazer é apoiar essas bases, e nisso as campanhas de impacto têm tido relevância, em que filmes fazem o papel de meio de intervenção. Entender como um filme é recebido pela audiência, também é muito importante. O problema é quando, ao estabelecer métodos e procedimentos, acredita-se que se pode medir o "impacto" de um filme, ou mesmo sua relevância. Continua Nichols, 
Para ser claro sobre um ponto: ter uma boa noção do modo como o público responde a um determinado trabalho, especialmente quando há oportunidades de fazer ajustes, não é uma coisa ruim. O problema surge quando isso se torna um problema de marketing empírico, parte integrante da cultura de commodities, por um lado, e quando a conformidade com definições e procedimentos pré-estabelecidos se torna um requisito para financiamento em primeiro lugar, por outro. Os cineastas podem usar todas as ferramentas que podem obter, mas ter a idéia de alguém sobre ferramentas de medição de impacto social imposta a eles é um desserviço bruto quando restringe opções, diminui prioridades e evita visões radicais (NICHOLS, 2016, p. 213, tradução nossa).

Em nosso propósito aqui, estamos a avaliar as possibilidades da produção de filmes documentários onde haja uma aliança entre cineasta e o Outro sujeito filmado, onde a medida para a avaliação de impacto do filme seja a do Outro sujeito filmado em aliança com o cineasta, ambos buscando estar bem informados sobre o campo de discursos e representações com os quais estão trabalhando. Nessas circunstâncias, por mais que vejamos a importância de trabalhos como a da Doc Society, que criou uma metodologia para projetos de impacto, por outro temos que concordar com Nichols de que a avaliação do impacto não deixa de ser algo muito impreciso e deve assim permanecer, pois se um filme é aliado de um Outro, não se pode perder de vista que o Outro é sempre incomensurável e imensurável. E que a produção de resistência muitas vezes opera seu contrário, uma recepção de filmes pode ouvir a voz do documentário justamente pelo oposto daquilo que seus produtores intencionam. Se o cineasta (e sua equipe) é Aliado do Outro sujeito filmado, sua medida é múltipla e contraditória como é o mundo que cerca o filme e o Outro.

A análise das condições de inserção do Outro sujeito filmado num processo de aliança tem um agravante, pois ela mesma é sujeita a múltiplas visões e vozes. Cineasta e Outro sujeito filmado podem ter expectativas diferentes tanto sobre a produção, quanto aos resultados do filme montado, e sua circulação e distribuição. Para nos atermos a um relato o mais próximo possível da visão e voz do cineasta, vou expor o processo de produção e circulação do filme, Em Nome do Meu Povo (2018), por mim realizado, como estudo de caso. Claramente, temos aqui um relato que é parcial, dado pelo cineasta e não 
pelo Outro sujeito filmado. É desse ponto de vista do cineasta que o estudo de caso a seguir se apresenta.

O filme nasceu a princípio de uma proposta de dar alguma resposta ao que eu via acontecer desde 2001, quando estava morando nos Estados Unidos e realizava estudos em antropologia, e alguns meses depois aconteceu o atentado "terrorista” sobre as Torres Gêmeas em Nova Iorque. Coloquei “terrorista” entre aspas porque esse rótulo, ao mesmo tempo que dá a entender um acontecimento que foi descrito, pelas mídias, dominantemente dessa forma, de outro oculta o contexto do próprio ato. Em pesquisa anterior, realizada no mestrado ${ }^{30}$, estudei os discursos sobre "terrorismo" vigentes na mídia, academia e sociedade norte-americana. O "terrorista” aparecia em meus estudos como um Outro quase sem história: do antigo "comunista” como um Outro inimigo do povo e do Estado norte-americanos, o termo "terrorista” vinha com uma carga que lhe tirava a necessidade de explicações históricas e sociais para o entendimento do ato. Bastava dizer "terrorista" que o Estado tinha o apoio de uma parcela da sociedade para a guerra e para medidas extremas. O "terrorismo” estava assentado num Outro "terrorista”, no discurso dominante o inimigo que pode ser eliminado e que não deve ser ouvido.

Sem ouvir os porquês dos atos do Outro, os Estados Unidos se lançaram em várias guerras, a primeira delas, cerca de um mês depois do ato em Nova Iorque, era a invasão do Afeganistão orquestrada com milícias locais e apoios militares de outros países liderados pelos norte-americanos. O Afeganistão foi o primeiro a sofrer as consequências do discurso do terrorismo, que não permitia refletir sobre os melhores meios de resolver a situação dada pelo ataque à Torres, pois para o discurso dominante terrorismo é guerra “dos fracos” (HOFFMAN, 2006, p. 23), e como sujeitos fracos terroristas não têm o que dizer como Outro a eliminar que são. Passei a olhar para o Afeganistão, sua história repleta de intervenções por outros países. O próprio Osama Bin Laden, um bilionário saudita tornado guerrilheiro e fundamentalista islâmico, havia sido aliado dos Estados Unidos na guerra afegã contra a invasão da União Soviética (1979-89). Passei a estudar a história do Afeganistão e isso me levou ao presente, e o presente, às pessoas cuja voz tinham chegado até mim de lá, e entre elas estava Malalai Joya.

Malalai escreveu uma autobiografia e foi a San Francisco, cidade onde eu morava, para apresentá-la em uma palestra. Assisti a palestra e fiquei fascinado com sua voz potente em tom e palavras, o que ela dizia coadunava com o que eu estava ouvindo sobre

\footnotetext{
30 Discourses on Terrorism, dissertação apresentada como pesquisa de mestrado no hoje extinto programa de Antropologia Social e Cultural da California Institute of Integral Studies em 2003.
} 
o Afeganistão por meio de mídias alternativas e pelos livros de história. Ao fim da palestra me pus na fila de autógrafos. Ao me aproximar de Malalai, contei que tinha a intenção de fazer um filme sobre algumas mulheres e suas lutas no Afeganistão, e que ela seria uma delas. Ela prontamente se mostrou aberta ao trabalho e me passou seu contato. Trocamos mensagens por dois anos, após os quais eu percebi que tudo o que eu gostaria de dizer para o mundo a respeito do Afeganistão, Malalai dizia. Ela seria a única personagem central para o filme, pois através dela contaríamos a história dos últimos 40 anos de guerras no país. Ela aceitou o convite, e colaborou gravando um vídeo de lançamento da campanha de crowdfunding online (financiamento colaborativo através dos sites Indiegogo e Catarse). Com seu vídeo em apoio ao projeto do filme, consegui financiamento de amigos e de desconhecidos. Em 2013 consegui fazer a viagem ao Afeganistão, e no segundo dia por lá fui ao seu encontro.

Quando nos encontramos, notei que ela não tinha muita ideia do que eu estava a fazer ali. Percebi que vinha me comunicando com sua equipe de apoiadores, que sabiam mais do que ela sobre mim, mas que ela tinha aprovado o projeto. Quando ela percebeu que estrearia o filme como personagem, me pediu o seguinte: "Você pode, sim, contar sobre mim e quem eu sou, mas só porque através do meu nome e fama que consegui, podemos contar outras histórias, a história do meu povo”. Prontamente eu sorri e lhe disse que aquilo era justamente o que eu buscava. Ela me disse: "Você deve me usar para que, através de mim, outras pessoas possam falar”. Eu lhe respondi que aquilo era justamente o que eu pretendia, pois através da voz dela, e de como ela conta sua história e a história do Afeganistão, poderíamos mostrar tudo que eu tinha aprendido que deve ser dito, e que se ela me ajudasse a construir o filme, teríamos impacto também no público do Afeganistão. Ela começou no mesmo dia a buscar pessoas para entrevistarmos e visitarmos, com ou sem a presença dela. Havia ocasiões em que ela não poderia comparecer a entrevistas, mas ela sempre esteve a par de todas as entrevistas e agendava mesmo quando eram realizadas em outras cidades sem a presença dela. Conversávamos sobre como fazer, o que incluir, e ela também tomava a iniciativa de agendar entrevistas sem me comunicar antes, apenas me pedia para registrar o que outros iam dizer.

Em todos os lugares ouvi pessoas falarem dela como alguém que as representa, que as ouve e depois leva suas reivindicações às instituições e pessoas concernentes às questões. Viajamos, eu e meu assistente local, para diversas regiões do país e entrevistamos pessoas de várias etnias que tinham sofrido nas mãos dos socialistas afegãos ou russos nos anos 1980, nas mãos dos “mujahideen criminosos”, ou seja, 
daqueles que lutavam contra a dominação soviética nos anos 1980, mas que se voltaram contra seu próprio povo também nos anos 1990 - diferentemente dos "verdadeiros mujahideen” que, segundo Malalai Joya, pararam a luta depois que os soviéticos se foram em 1989. Colecionamos entrevistas com aqueles que Malalai chamava de "vítimas" das diferentes guerras causadas por soviéticos, mujahideen, fundamentalistas, e invasores como os Estados Unidos, entre outros grupos. Como queria Malalai, fizemos um filme que buscava a "voz dos sem voz", as pessoas massacradas nas guerras envolvendo países interessados no Afeganistão e senhores de guerra locais, muitos patrocinados pelos Estados Unidos, Irã, Paquistão, Rússia e que até hoje dominam a política afegã. Os “sem voz” eram os que ficavam em meio a tudo isso, sem necessariamente participar, mas que sofriam as consequências das guerras.

Numa cena do filme, Malalai afirma que eu como cineasta era um aliado ao dizer a uma assembleia de anciões em sua cidade natal de Farah:

Em minha viagem aos EUA, eu conheci Rodrigo, um professor universitário que está filmando agora, e ele expressou sua vontade de fazer um documentário baseado no meu livro. É alguém que tem as mesmas visões que todos nós. Ele não concorda com a invasão do Afeganistão, apóia os direitos das mulheres e a educação. É contra os Talibã, contra os senhores da guerra e as décadas de guerra. É contra todos eles. Ele tenta usar sua profissão como cinegrafista para servir ao nosso povo (...) Não deve ser somente eu, mas através de mim, todas as vítimas. Conforme ele viaja para diferentes províncias e faz entrevistas, as vítimas das guerras podem levantar suas vozes para o mundo todo, o que tem muito valor para nós, já que cada um aqui é um herói incógnito do Afeganistão. Seus sacrifícios e conquistas têm que ser transmitidas.

Ao fazer esse filme, nosso interesse, meu e de Malalai, foi de criar uma contramemória, contar a história das guerras do ponto de vista dos que mais sofreram seus efeitos, as pessoas que perderam familiares, amigos, ou uma perna em guerras em que a maioria nem participou, apenas sofreu suas consequências. Como afirma a acadêmica e documentarista Angela Aguayo (2014, p. 176, tradução nossa),

A documentação da contra-memória experimentada por pessoas marginalizadas cujas histórias são amplamente ignoradas é um terreno delicado que deve ser 
cuidadosamente navegado. A questão de “em cujo interesse” a história está sendo construída deve ter precedência. Esta é uma obrigação pesada: uma que eu não levo de ânimo leve e nem sempre acerto. Há uma rica história de profissionais da mídia agindo de maneiras que são frequentemente acríticas, dispostas a sacrificar a justiça social e a análise sistemática em troca de registrar traumas para um ganho profissional rápido.

O processo de montagem de Em Nome do Meu Povo também foi participativo e colaborativo até o final. Realizamos diversas montagens, Malalai sentava com sua equipe para assistir, anotavam sugestões de mudanças para me enviar pela internet. Eu avaliava os pedidos de mudança e acabei realizando praticamente todos da forma que me pediam. Quando tinha divergências, geralmente se baseavam na necessidade de deixar mais claro para um público não-afegão o que estava sendo contado no filme. Nosso público principal sempre foi o próprio povo do Afeganistão. Porém Malalai como ativista de atuação internacional sabia também da importância de levar o filme a outros países, pelo impacto desses no seu país. Criamos um filme que conta a história de um jeito que não é muito contada no Afeganistão, onde há condenação seletiva de crimes cometidos por senhores da guerra e militantes. Malalai condena todos os que praticaram crimes contra qualquer etnia do país. Seu senso de justiça não faz diferença por etnia, religião, nação, e isso permite que ela traga uma voz que é liberatória em seu país pois não está baseada na visão de algum grupo contra outros.

Essas estratégias e técnicas de produção participativa que utilizamos não foram inventadas por nós, obviamente. Como já demonstramos, desde seu início, ao menos desde Flaherty, o documentário foi realizado de modo participativo entre cineasta e sujeitos filmados. Cada produção escolheu seu modo de inserir a participação dos sujeitos filmados, chegando a seu modo de fazê-lo por razões e contingências diversas. Por vezes, os cineastas mantiveram a decisão final sobre a montagem, até porque tinham o domínio da produção e seus Outros sujeitos filmados não. Por outras, os cineastas chegaram ao ponto de instrumentalizar, capacitar tecnicamente os Outros sujeitos filmados na produção de filmes e vídeos, como no caso do projeto Challenge for Change, realizado por instituições do governo canadense e que tinha como propósito criar filmes e vídeos de base comunitária visando “dar voz aos sem voz” e com isso diminuir a pobreza. O programa, iniciado em 1967, produziu filmes de diversas maneiras, alguns em que os cineastas detinham todo o controle sobre a produção, e filmavam no estilo Cinema Direto ou Cinema Vérité, e outros onde as pessoas comuns, os Outros sujeitos filmados, eram capacitados para fazer parte da produção. Filmes sobre questões indígenas, das mulheres, 
de trabalhadores eram comuns. John Grierson, que tinha sido contratado à época pelo governo canadense para coordenar produções, era um entusiasta do programa pois afinal seriam feitos filmes com vistas a mudanças sociais, mas criticava a descentralização da produção, na parte do programa que visava capacitar pessoas comuns a produzir pois “isso era levar as coisas longe demais” (LOW In WAUGH et al., 2010, p. 15). O projeto visava criar um canal duplo de comunicação, onde a população, através dos filmes, mostraria os problemas que enfrentava e, esperava-se, poderia levar soluções ao governo e ao restante da população. O programa desenvolveu métodos de trabalho que envolviam aprovar o corte final dos filmes junto aos sujeitos filmados, antes que qualquer outra comunidade ou mesmo o governo pudesse vê-los. O livro Challenge for Change: Activist Documentary at the National Film Board of Canada traz testemunhos das produções realizadas, onde em algumas os efeitos dos filmes e vídeos para mudanças sociais são mais perceptíveis, em outras, os testemunhos de participantes comunitários revelam o processo de produção como mais importante que os filmes e vídeos finais, pois ali o mais importante teria acontecido em termos de suas ações.

Em outros países e em datas atuais, muitas escolas, pesquisadores e documentaristas renovam o filme documentário como instrumento de mudança social. Na Argentina, país onde o documentário continua a ser valorizado como instrumento de luta social, filmes têm sido realizados frequentemente em apoio a movimentos indígenas, campesinos, de trabalhadores, mulheres, entre outros. O legado do povo argentino é de um povo que se manifesta frequentemente politicamente nas ruas, chega a derrubar governos, e não é de assombrar que também tenha muitos documentaristas, escolas e coletivos de documentário ativistas. As crises de 2001 que assolaram o país levado pelo neoliberalismo econômico a uma crise econômica, deram novo ímpeto às produções de filmes documentários aliados de movimentos sociais. Em aliança com os movimentos por autogestão, mais críticos do Estado argentino por sua subserviência ao neoliberalismo, surgiu o Movimento de Documentaristas, que é descrito dessa forma por alguns de seus documentaristas mais expoentes como Fernando Buen Abad e Miguel Mirra:

$\S$ O Movimento de Documentaristas é estéril se não se move com os movimentos populares. Não é nada sem o encorajamento do movimento social.

$\S$ O lugar do documentarista é a luta contra a dependência e a escravidão. 
§ O lugar do movimento é a luta pela soberania política, econômica e cultural.

§ O lugar do movimento é a construção e participação criativa de meios de

comunicação popular e comunitária.

$\S$ A autogestão deve ser entendida como um instrumento de poder e aprendizagem a serviço da independência política.

§ Independência e autogestão são complementares à auto-representação frente à

sociedade global e participação das bases.

§ O movimento precisa de ação para propor linguagens audiovisuais em construção permanente.

$\S$ O movimento é mobilizado por ações humanas documentadas.

$\S$ O lugar dos documentaristas é o lugar de um aprendiz que deve tomar nota e

treinar-se politicamente se você não quer perder o passo dos movimentos da história.

É preciso notar que colocamos os ditos do Movimento de Documentaristas aqui não como um manifesto ou um método a virar modelo para documentaristas que querem representar a voz de Outros sujeitos em documentários, mas como um outro modo de se fazer, como uma das possibilidades de se pensar a produção de filmes. É claro que cineastas correm sempre o perigo de romantizar a voz do Outro como sendo portadora de verdades salvadoras. É claro que o mundo não funciona perfeitamente, isto é, para muitas situações não é possível que um filme seja realmente de ajuda, ou que as pessoas tenham saídas fáceis. Os filmes que se colocam como "saídas” perdem a relação com os movimentos sociais ou com ações sociais que representam. Explica Miguel Mirra (In PACHECO, 2018, p. 73, tradução nossa):

O Movimento de Documentaristas é totalmente contra a realização de filmes de vanguarda. A diferença do cinema militante era que esse faz uma mensagem para conscientizar, mobilizar, agitar, para o que quer que seja sempre como um cinema feito por uma vanguarda. Isto é o que muitos desses grupos de filmes militantes continuam a fazer, o que não é certo ou errado, nós seguimos de outra maneira. Nós não fazemos cinema militante. 
Miguel Mirra estabelece aqui o que seria a diferença de um cinema militante que é feito para Outros, para um cinema feito com Outros, que é a sua proposta. Para fazer o cinema com Outros, é necessário pensar em quantos níveis de participação do Outro na produção se pode ter. Mirra e o Movimento de Documentaristas discutem o documentário como um meio de intervenção, pautado nos movimentos sociais e sujeitos filmados e suas aspirações. Discutem para isso a inclusão dos sujeitos filmados na produção. O quanto o Movimento é capaz de cumprir com suas aspirações, é uma pergunta a ser feita aos sujeitos filmados, tendo em conta que os efeitos de documentários, especialmente se fazem parte de movimentos e ações sociais, são muito difíceis de discernir do restante das ações do Outro.

\subsection{Como se apresenta a voz do Outro no documentário}

A alteridade, como vimos, se coloca como um problema para a representação. Mas é um problema que permanece como problema muitas vezes somente no nível da teoria. Pois na prática, o documentarista é obrigado a fazer escolhas e, muitas vezes, fechar um discurso - emancipatório, ao menos na tentativa - sobre o Outro. Se o faz como Aliado, o documentarista fará sua representação sobre o Outro com o Outro tendo relativo domínio sobre os discursos que estão sendo enfrentados, bem como aqueles que estão sendo reproduzidos como forma de resistência, mesmo que parcial, mesmo que inerentemente não-total e falha. Nesse sentido, temos que colocar em questionamento qualquer fórmula ou protocolo para a representação do Outro. Por isso, não temos como ter um filme modelo na representação do Outro. Pois a crítica da representação da alteridade não pode dizer que há a maneira certa de representar o Outro. Essa maneira única não pode existir. Mesmo quando se coloca como uma maneira "não-finalizada, num falar de um modo que ainda não é parte de um sistema completo” (SHOTTER In HUSPEK \& RADFORD, 1997, p. 26), mesmo nessa maneira que seria aberta, essa pode ser justamente aquilo que o Outro não precisa.

Imaginemos fazer um filme que fale que um povo indígena acredita que sua terra, seu território, é sagrado como fazem os aborígenes no filme Two Laws, para depois dizer que "isso é apenas um modo de ver”? Em resposta aos discursos dominantes sobre o Outro, em que imperava até pouco tempo certa visão metafísica do Outro, hoje vemos reinar outra metafísica, a que relativiza os discursos sobre o Outro como apenas 
construções, sem lastro na realidade. É o mesmo tipo de cultura dominante que opera sobre os filmes documentários como apenas filmes, radicalizando a importância da “verdade do filme” e desconsiderando o que o filme tem a dizer sobre o mundo. É interessante como, a partir dos anos 1990, quando ressurge a produção em escala de documentários no Brasil e no mundo, ressurge também o discurso do documentário como arte desprovida de intencionalidade política-cultural. Obviamente, esse discurso impera mais nos círculos de especialistas e acadêmicos, e menos no consumo e recepção por parte do público. Os documentários ainda são vistos como fazendo suas asserções sobre o mundo, referindo-se diretamente ao mundo. Mas, como já apontamos, grande parcela da crítica, da universidade, dos festivais e das escolas de cinema no Brasil têm em grande parte rejeitado pensar o documentário em suas relações com o mundo vivido, em favor de pensar o documentário como arte. Nesse discurso, arte é o modo de criação de uma realidade paralela àquela do mundo vivido.

Ao representar a voz do Outro como arte, há uma vontade de valorização do Outro eticamente, há um temor sobre o fechamento da representação do Outro. Ao não querer que se cristalize um discurso potencialmente perigoso para o Outro, há uma preocupação louvável de que o discurso unívoco feche em conjunto também possibilidades de vida para esse Outro. Sem dúvida, essa preocupação com fechamentos unívocos sobre o Outro deve estar acima de qualquer questão apenas comunicativa, deve se tornar uma preocupação ética. Porém, o que vemos em teorias dominantes sobre a questão da representação em processos de comunicação mediatizada, mesmo aquelas que dizem se voltar a pensar o Outro eticamente, é que descartam as possibilidades de representação do Outro para além do Outro como ser unívoco. Comunicação não é tudo que importa - nem apenas qualquer relação. Faz-se necessário indagarmo-nos sobre a qualidade da relação estabelecida - seja comunicativa, seja de outro modo? Que efeitos para o Outro e para o mundo são trazidos por essa relação? A questão da voz se coloca novamente como um ponto articulador, pois a voz é uma produção que precisa considerar seu(s) público(s), já que voz é sempre relação.

A luta para acabar com a dominação, a luta individual para resistir à colonização, para se deslocar de objeto para sujeito, se expressa no esforço de estabelecer a voz libertadora - aquela maneira de falar que não é mais determinada pelo seu status de objeto - o ser oprimido. Essa maneira de falar é caracterizada pela oposição, pela resistência. Exige 
que os paradigmas mudem - que aprendamos a falar - a escutar - a ouvir de uma nova maneira.

Para fazer a voz liberada, é preciso confrontar a questão da audiência devemos saber a quem falamos. Quando comecei a escrever meu primeiro livro, Ain't I A Woman: black women and feminism, o manuscrito inicial completo era excessivamente longo e muito repetitivo. Lendo-o criticamente, vi que estava tentando não apenas abordar cada público potencial diferente - homens negros, mulheres brancas, homens brancos, etc. -, mas que minhas palavras foram escritas para explicar, aplacar, apaziguar. Eles continham o medo de falar que muitas vezes caracteriza o modo como aqueles que estão numa posição mais baixa dentro de uma hierarquia se dirigem àqueles em uma posição mais alta de autoridade. Aquelas passagens em que eu falava mais diretamente às mulheres negras continham a voz que era a minha mais verdadeira - foi então que minha voz foi ousada, corajosa. Quando eu pensava sobre a audiência - a maneira pela qual a linguagem que escolhemos diz quem é que colocamos no centro do nosso discurso - eu enfrentei meu medo de colocar eu mesma e outras mulheres negras no centro da fala. Escrever este livro foi para mim um gesto radical. Isso não só me colocou frente a frente com essa questão de poder; isso me forçou a resolver essa questão, a agir, a encontrar minha voz, a tornar-se aquele sujeito que poderia colocar a si mesma e a outras pessoas como ela no centro do discurso feminista. Eu fui transformada em consciência e ser (HOOKS, 1989, p. 15, tradução nossa).

Para bell hooks, não há escolha senão “chegar à voz” - onde não há a primazia do ato de falar sobre o conteúdo da fala. A fala de uma voz marginalizada ou silenciada é ato de resistência e busca efeitos políticos. Ela deixa de ser apenas diálogo para exigir mudanças na situação de opressão. Como uma fala situada em relações de poder e saber, sua ressonância se dá quanto mais ela confronta essas relações diretamente a partir do seu "lugar de fala” (RIBEIRO, 2017), no caso de hooks, como mulher negra e feminista que busca novas possibilidades de vida para as mulheres e negras. Sua fala exige mudanças sociais e, como tal, não pode ser interpretada apenas como diálogo: há um mundo e modo de vida ao qual ela se refere ao falar. Mas estamos falando de uma pessoa que já tem para si muitas questões sobre as quais precisa falar e apontar como seus problemas ou 
soluções. Aqui a tarefa do cineasta como Aliado seria de amplificar sua fala num filme, sem desvirtuar ou diminuir, colocando-a como definidora da voz do documentário. E quando o Outro não fala necessariamente como uma voz libertadora? Ou quando essa leitura é difícil para o cineasta, qual é a tarefa do cineasta Aliado?

Como Aliado, o cineasta deve trabalhar para amplificar em primeiro lugar seu Outro sujeito filmado. Mas não pode se esquecer de Outros sujeitos que não falam no filme, mas que podem se identificar com o Outro sujeito filmado do filme. Desse modo, o cineasta pode buscar em outras falas a ampliação do debate trazido pelo seu personagem do filme, porém como Aliado deve confirmar que as outras falas coligadas colaboram para a voz do seu personagem. Como fazer isso? O único que pode confirmar se sua fala é ampliada ou diminuída num filme, é o Outro sujeito filmado propriamente. Caso em que o cineasta, ao ter partes do filme recusadas ou haver pedidos de modificação do filme, deve avaliar se consegue continuar a ser um bom Aliado para o seu personagem ou se o personagem precisa ser outro. De toda forma, a única possibilidade de uma aliança progredir é se o filme trabalha em acordos entre cineasta e Outro sujeito filmado. Ao fazer isso, o cineasta precisa estar ciente de que ao afirmar uma voz liberatória num filme, necessariamente vai provocar críticas e resistências ao filme, se o mesmo é realmente portador dessa voz.

Para bell hooks, uma voz libertadora não é apenas uma pessoa falando demais em público. Uma pessoa pode falar bastante em público, mas falar apenas de modo reativo e crítico a outros, sem falar de um lugar de auto-afirmação e de poder próprio. A fala que só diz "Não!" a Outros ou a estruturas sociais sem se colocar como local de (auto)afirmação, do “Sim!” a si mesmo ou a aliados, é uma fala sem poder de libertação. A voz libertadora não apenas ressoa ou fala alto e longe, ela inclui o sujeito da voz numa afirmação de si mesmo e num reconhecimento dos Outros. Nesse reconhecimento, mesmo que crítico, dos Outros, está alguma chance de ser ouvida. Porém - sempre há um porém nessa questão da voz - como sempre relacional, para ser ouvida, uma voz precisa ser recebida com um mínimo de empatia. bell hooks sabe muito bem que uma voz libertadora é perigosa para os poderes estabelecidos, e que estes se voltarão contra essa voz, negando-lhe seu caráter libertador.

Quando nos atrevemos a falar com uma voz libertadora, ameaçamos até mesmo aqueles que inicialmente dizem querer nossas palavras. No ato de superar nosso medo da fala, de ser visto como ameaçador, no 
processo de aprender a falar como sujeitos, participamos da luta global para acabar com a dominação. Quando terminamos nosso silêncio, quando falamos com uma voz liberada, nossas palavras nos conectam com qualquer pessoa, em qualquer lugar que viva em silêncio. $\mathrm{O}$ foco feminista nas mulheres que encontram voz, no silêncio das mulheres negras, nas mulheres de cor, levou a um interesse crescente em nossas palavras. Este é um momento histórico importante. Ambos estamos falando de nossa própria vontade, do nosso compromisso com a justiça, da luta revolucionária para acabar com a dominação, e simultaneamente chamadas a falar, "convidadas" a compartilhar nossas palavras. É importante que falemos. O que falamos é mais importante. É nossa responsabilidade coletiva e individualmente distinguir entre a mera fala que é sobre o auto-engrandecimento, exploração do "outro" exótico, e o chegar à voz que é um gesto de resistência, uma afirmação de luta (HOOKS, 1989, p. 18, tradução nossa).

Uma fala libertadora é uma em que se dá formas a pensamentos e emoções, e entendimentos novos surgem sobre a situação de uma pessoa como Outro da sociedade dominante que busca libertação. Há um duplo trajeto de identificação de si como pessoa situada num mundo em que há brechas para se afirmar a própria vida, ao mesmo tempo que há um estranhamento em relação às estruturas de opressão. A afirmação de si não é pura, ela exige também afirmar as dificuldades de uma vida em luta constante. Essa vivência que busca auto-afirmação e afirmação da própria vida, ao mesmo tempo que reconhece que há embates em relações com o dominante, é um espaço ao mesmo tempo de auto-estranhamento pelas condições mesmas de se reconhecer como parte de uma sociedade que não afirma o Outro do dominante em sua totalidade. Além disso, como coloca bell hooks, a voz libertadora é uma que não é individual apenas, ela é já parte de relações, é sempre uma co-voz, voz como resultado de embates, de auto-afirmação e de auto-estranhamento, afirmação de possibilidades e estranhamento em relação a situações e estruturas sociais opressoras. A voz libertadora não é apenas crítica e não apenas aponta erros: porque ela parte da auto-afirmação, ela não é moralista. Por mais que possa falar de inimigos, o faz por conta das ações desses dentro de estruturas que os possibilitam de agir. A voz libertadora visa mudanças estruturais e reconhece que sujeitos são produzidos dentro delas. 
Um filme que trabalha com uma voz libertadora é Eu não Sou Seu Negro (Direção Raoul Peck, 2016). O filme começa dizendo que é co-escrito por James Baldwin ${ }^{31}$ e baseado no que seria o seu último livro, mas que Baldwin não escreveu antes de falecer. O filme é uma tentativa de escrever o texto do que seria o livro, reunindo escritos de Baldwin, lidos em voice-over por Samuel L. Jackson, e registros de falas de Baldwin em programas de televisão, entre as décadas de 1950 a 1970. O filme não tem pessoas interpretando o que Baldwin diz, porém há uma montagem que interpreta ao dividir o filme em capítulos com temas ${ }^{32}$. Nesse filme, Baldwin como Outro representado, não é filmado pelo cineasta, não há uma relação pessoal envolvida. O Outro, Baldwin, já não está vivo para decidir sobre sua representação. A ética do cineasta para com Baldwin, passa, portanto, para a relação com aqueles que Baldwin representa enquanto Outro do dominante: o "negro" que Baldwin recusa como Outro do "branco" no modo como sua alteridade foi construída. O "negro” como inferior e subalterno, é o negro que Baldwin problematiza, desconstruindo o seu lugar como Outro. Nesse sentido, Baldwin é aqui apenas um meio para o cineasta falar, não apenas de Baldwin, mas de usar Baldwin como instrumento de intervenção nos discursos correntes sobre o Outro chamado de "negro”. A aliança primeira do cineasta nesse caso está com os povos assim tornados Outros pela supremacia branca. Ao mesmo tempo, o filme não utiliza de outras vozes a interpretar o que diz Baldwin.

O filme também usa o passado para pensar o presente: às falas de Baldwin seguem imagens da atualidade para mostrar como o que ele falava ainda vive, como se dissesse que a História é o que acontece hoje, que é algo que o próprio Baldwin afirma. Aqui o cineasta imprime na voz do documentário uma crítica que é sua, ao presente. A montagem, também sua, imprime a voz do documentário. No entanto, ao se firmar principalmente nas falas de Baldwin, por quase todo o tempo do filme, essa voz se imprime como fala e som acima das imagens, pois por mais que há imagens fortes como a de brancos ridicularizando negros ou policiais violentando-os, as falas de Baldwin ainda dão o tom e o comentário sobre o que vemos. No filme, a voz de Baldwin tem caráter dominante. Por meio das falas de Baldwin, o documentário confronta a fabricação

\footnotetext{
${ }^{31}$ James Baldwin, escritor negro norte-americano, influenciou gerações ao escrever histórias que se dirigem a uma análise do racismo estrutural na cultura norte-americana. Ele atingiu renome ainda em vida e se tornou uma personalidade pública.

${ }^{32}$ Esse é fundamentalmente um documentário de montagem e de arquivo (com imagens históricas) ou seja, ele fala de Outro mas sem filmar ou entrevistar ou interpelar outros - o que é um gênero de documentário bem frequente, mas distinto daqueles que constroem personagens por meio de entrevistas ou em contato com o realizador. Nesse caso, não é o documentarista que fala diretamente do outro, mas ele mostra Baldwin, que problematiza seu lugar como Outro. Há mais camadas de representação e de mediação nesse caso.
} 
de estereótipos e preconceitos pelo cinema americano, enfrentando o discurso dominante sobre o negro. Baldwin demonstra sua admiração, não sem críticas, a alguns dos principais líderes do movimento negro americano na época: Malcolm X, Martin Luther King Jr. e Medgar Evers.

É interessante como Baldwin consegue ser crítico, por exemplo, da radicalidade em termos de Malcolm X, ao mesmo tempo em que entende que ele tem seu espaço legítimo para falar e ser. Baldwin age da mesma maneira com a cultura americana que ele entende como dominantemente racista, porém sua crítica parte da afirmação de si e dos negros como tendo seu lugar e importância na sociedade que não reconhece esse lugar e precisa de mudanças por isso. Baldwin não parte do moralismo e não quer vingança, ele acredita que a libertação dos negros é também a libertação dos Estados Unidos, e partindo desse lugar de auto-afirmação, ele consegue - por mais crítico que seja dos modos de opressão e de reprodução do racismo, seja de atitude ou estrutural -, falar de um lugar libertador. Sua voz é libertadora porque fala como um indivíduo que pertence a determinados grupos: negro, norte-americano e por isso fazendo parte da mesma sociedade dos brancos. Sua voz é libertadora porque não nega vida aos brancos, pede mudanças na vida de todos os norte-americanos para que as comunidades negras possam ter seu espaço de liberdade em igualdade.

Obviamente, como colocado anteriormente, a voz libertadora provoca reações contrárias também, e muitos brancos liam nos escritos de Baldwin uma voz que afirmava uma guerra aos brancos, mesmo isso sendo algo com que ele não compactuava. O diretor do filme, um negro haitiano, já havia lido Baldwin na adolescência, e para ele o escritor conseguia colocar em palavras e pensamentos questões que ele percebia. Como negro, Baldwin lhe falava sobre sua situação, mesmo sendo de outro país, pois algumas contingências se intersectavam. Como negro norte-americano, Baldwin conta que nos filmes de faroeste, em que havia os brancos-mocinhos e os índios-selvagens maus, Baldwin primeiro se identificava com os brancos dos filmes, e depois diz que levou um choque quando descobriu que, na verdade, os indígenas eram os negros também. Ele passa de um processo de identificação com o dominante, para identificação com o Outro do dominante, aquele que corria sempre o risco de ser aniquilado por ser diferente e tornado Outro. Disso e de outras experiências, Baldwin conclui que o "negro”, como um discurso do Outro, de uma alteridade discursiva do dominante, é uma criação branca para subjugar as comunidades chamadas de negras, ao modo como em outros lugares o termo 
“oriental” (SAID, 2003) foi usado para dominar o chamado Oriente e o termo "primitivo” ou “selvagem” (TORGOVNICK, 1990) para dominar povos nativos das américas.

Se o cineasta é parte do mesmo grupo ou comunidade do Outro sujeito filmado de alguma forma, a distância entre ouvir e afirmar a voz do Outro pode ser menor. Porém, como estamos todos sujeitos a dominações, identidade com o Outro não é garantia de escuta. Não há qualquer garantia de escuta nesse sentido, pois todos passamos, embora de maneiras diferentes, por socializações em dominações. Não se pode ignorar discursos dominantes sobre o Outro, pois isso é uma nova forma de reproduzir dominações pelo não-enfrentamento. O Outro muitas vezes esqueceu sua memória, história de seu povo, sua contra-memória. A voz liberatória é interseccional ${ }^{33}$, isto é, sem hierarquia de opressões, apesar de que quando o Outro fala em voz liberatória, o faz realizando uma priorização de vozes que é inerente a suas posições numa hierarquia. Porém, isso é muito diferente de criar uma hierarquia universal de opressões. A voz liberatória necessariamente encontra resistências a ela, pois o não-dominante resiste por necessidade e é resistido. Não se trata de “dizer a verdade ao poder” (NICHOLS, 1991), pois isso presume uma outra posição de autoridade: do cineasta que tem legitimidade para dizer apenas pelo dito. Uma resistência às formas de dominação não se resume a texto ou palavras. As palavras precisam estar sustentadas em práticas. Um filme sozinho não causa mudanças sociais, mudanças são feitas pelas pessoas que já carregam consigo a disposição para mudanças. Filmes intervém e podem acelerar o processo. O filme de Errol Morris, The Thin Blue Line (1988), por exemplo, influenciou na reversão de uma condenação por crime. O filme de Morgan Spurlock, Super Size Me (2004), sobre a experiência a qual o cineasta se submete, de dizer "Sim" a tudo que lhe é oferecido em lojas da McDonald's em refeições de tamanho maior, e depois de 30 dias sua experiência tendo que ser terminada por ele estar doente e obeso, culminou em apenas seis semanas depois o McDonald's dando fim ao seu programa de “Super Size”, embora a empresa negue vínculos desse fato aos efeitos do filme. Muitos filmes mostram que dizer verdades ao poder tem resultados.

\footnotetext{
${ }^{33}$ Conceito cunhado por Kimberlé Crenshaw para aglutinar as conversas dentro do movimento feminista negro sobre as diversas opressões que atingem as mulheres negras e outros grupos e como dar importância ao cruzamentos e interstícios entre opressões e como podem desse modo ser produzidas resistências que respondam a essa multiplicidade de opressões, inclusive aquelas que não afetam um sujeito diretamente, mas afetam suas possibilidades de vida porque perfazem estruturas opressivas que se afetam mutuamente. Desse modo, em relação a mulheres negras, por exemplo, não se pode pensar raça, gênero e classe de maneira isolada, sem interligar as três conjunturas sem reproduzir discursos e práticas opressivas sobre elas. Ao mesmo tempo, pensando-se na forma da interseccionalidade, pensa-se o combate a todas as formas de opressão, pois todas têm de algum modo um reforço na existência de outras opressões.
} 
Uma crítica baseada em Foucault poderia perguntar: e quem vai dizer sobre o poder para a verdade?; Quem pode determinar o que é resistir? "Nesse sentido a teoria não expressa, traduz, ou serve para aplicar a prática: é a prática” (FOUCAULT, 1977, p. 208). Uma crítica baseada em Derrida (1978) poderia afirmar que o crítico ser autoconsciente e não-dogmático precisa ser uma prática desconstrucionista, ser não-final, ser o vir-a-ser ou é só mais do Mesmo: metafísica, afirmação de uma Verdade e negação do Outro. É possível a pluralidade de visão num crítico individual? Não seria necessário, para isso, incluir outras vozes e mesmo assim possivelmente falhar? Uma voz é muitas vozes que nos ocupam, que podem nos deixar dóceis e úteis, ou preparados para resistir. Voz é diferença, confronto de vozes, voz só existe como co-voz, como relação, ao mesmo tempo em que uma voz é ligada a um corpo, uma voz só existe em face de outras vozes, não existe em si, não é uma essência. Pois se para existir a voz precisa de uma linguagem, ela só existe em face do Outro. O "pensamento não pode primeiro ser linguagem a não ser que se reconheça que o pensamento é primeiro e irredutivelmente uma relação com o outro.” (DERRIDA, 1978, p.104). No entanto, quem fala é sempre uma voz individual, e ligá-la a outras vozes é tomar um posicionamento em relação a elas. Dizer que alguém fala por Outros é tomar posição, contra outras posições possíveis. Quem coloca uma voz, a coloca numa relação que é uma “continuação numa história de interações” (KRIPPENDORF In HUSPEK \& RADFORD, 1997, p. 57). Há sempre uma parcialidade na voz, é sempre um $e u$ individual que fala, e sua pertinência e combinação, numa história de vozes e interações é uma questão de se reconstruir as relações entre vozes e práticas. A “atividade comunicativa” (LANGSDORF In HUSPEK \& RADFORD, 1997, p. 91) que dá origem à linguagem, dá também a condição para que a voz apareça numa história de relações em que um indivíduo é formado linguisticamente e subjetivamente enquanto uma pluralidade de vozes. Em sua dissertação de mestrado intitulada $A$ voz do outro no cinema brasileiro contemporâneo: a questão da primeira pessoa, Eduardo Silva (2009) afirma:

Todos os esforços para que se acabasse com o "modelo sociológico”, o saber unívoco e centralizado, e deixasse o outro falar "derrubaram o pedestal do documentarista”, como afirma Bernardet, contudo, não permitiram que o outro se expressasse integralmente, pois "a possibilidade de o outro de classe expressar-se está em relação direta com a propriedade dos meios de produção”. (BERNARDET, 2003, p. 
217). E, de certo modo, essa crítica talvez seja cabível ao documentário de perfil reflexivo, cujo esmero em tentar explicar suas metodologias para abordar o outro (ora revelando bastidores, ora a presença do diretor) criou, em alguns momentos, um método do discurso dentro do próprio filme, relegando, porém, a tomada dos meios pelo oprimido dos anos 60, ou pelo excluído da contemporaneidade. Sinal de que nada mudou e que é preciso relativizar ao falar de um cinema que deu e que dá voz.

\section{(...)}

Mais do que isso, alguns documentários inauguraram uma tendência não exatamente inovadora na linguagem, mas peculiar nos propósitos envolvidos: a de esquecer o outro de classe, admitindo-se a incapacidade de representá-lo ou de promover a auto-representação. Esse tipo de documentário, no qual o cineasta não responde mais pelo mundo, mas somente pela sua subjetividade, corresponde ao que Fernão Ramos chama de ética modesta.

\section{(...)}

Como ressalta Fernão Ramos, esse tipo de documentário, em que o cineasta estabelece asserções sobre a própria vida, caminha na mesma linha do filme de depoimentos, "mesmo quando as falas são articuladas pela presença do diretor” (RAMOS, 2008: 24), como é o caso de Eduardo Coutinho. Os enunciados assertivos, antes proferidos pela voz do saber, agora são assumidos "por entrevistas, depoimentos de especialistas, diálogos, filmes de arquivo (flexionados para enunciar as asserções de que a narrativa necessita)", resultando em vozes que falam do mundo ou de si. E como também mostramos anteriormente, quando se faz necessário para o diretor falar sobre o outro, essa fala está carregada de reflexividade, buscando sempre evidenciar o processo fílmico e a opacidade do discurso, a parcialidade do diretor em diálogo com as parcialidades do outro.

O que vemos, portanto, no documentário, é que a sobre-valorização da voz como fala do outro - uma fala qualquer, podendo ser fragmentada, desprovida de politização, subjetivista ou até abstrata - tomou o lugar da voz do Outro como voz da alteridade que possa reivindicar um lugar de fala diferente, do oprimido que busca um espaço de voz que é ao mesmo tempo sobrevivência e disputa de projetos de vida. Saímos de uma 
cultura cinemática dominante do Outro como tendo uma voz que pode irromper como chamado para mudanças sociais, como uma busca de uma voz potencialmente liberatória, para uma cultura cinemática dominante da voz do Outro apenas como fala entre outras falas. A voz do Outro no documentário hoje dominante no Brasil atua com palavras que nem ao Outro pertencem mais, pois pertencem ao filme como arte, e ao diretor do filme como artista que orquestra as falas. Quanto mais o cineasta artista implica sua subjetividade na construção do filme, maior o valor hoje dado ao documentário. Com isso o potencial do Outro ser ouvido como pertencente a um mundo que clama por ações, valores e práticas, é desvalorizado pois a voz do documentário é - ao menos parcialmente, ao menos enquanto potencial - desconectada do Outro em sua materialidade e existência. A tarefa do documentarista da “ética modesta” (Idem) é a de não se envolver com o Outro em suas lutas por uma vida melhor.

Mas podemos perguntar, a partir de Fernão Ramos: e se a valorização da ética do documentário que desconstrói sua voz, que se posiciona de maneira modesta em relação ao mundo ao qual se refere, for realmente apenas mais um momento da ética dominante do documentário? E se pudermos provar que, justamente no momento em que as chamadas minorias estão fazendo filmes, uma ética que diz que não se fala sobre as lutas do Outro no mundo vivido, é uma ética opressiva? E se o caminho não for apenas para frente, na história do documentário? E se pudermos reafirmar legados do documentário, reconhecer as várias possibilidades técnicas, as várias estratégias possíveis para o documentário se tornarem novamente abertas para nosso uso, visto que nossa ética é a de fazer um mundo melhor para todos, principalmente para aqueles que mais nos importam, os Outros sujeitos filmados oprimidos? E se o documentário pudesse novamente ser pensado como um instrumento de mudanças sociais, a partir de alianças com grupos oprimidos que lutam por mudanças?

Mas alguma coisa vem mudando na ética do documentário no Brasil, e não apenas porque os grupos minoritários agora finalmente tenham em mãos os meios de produção, ou porque tenhamos, de uma hora para outra e sem esforço, uma sociedade justa. As estruturas opressoras e de criação de desigualdades modificaram algumas relações nos últimos anos, em parte devido a programas de políticas afirmativas, inserindo negros e indígenas na universidade, por exemplo, em parte por lutas renovadas com a nova onda feminista. Os avanços em políticas públicas visando melhorar a vida de grupos oprimidos se deram também nas políticas de cultura nos anos 2000 a 2015, no Brasil, sob o governo do Partido dos Trabalhadores (PT). Ao ser deposto num golpe institucional, o governo a 
tomar o poder foi rápido em buscar frear as políticas públicas em cultura, chegando a extinguir o Ministério da Cultura no Brasil e recuando após protestos ${ }^{34}$. Em 2019, um novo governo levou a cabo a extinção do Ministério da Cultura e de programas essenciais de financiamento ao audiovisual no Brasil ${ }^{35}$. Apesar desse retrocesso nas políticas públicas, e apesar de muitas disparidades no acesso a recursos e produção de filmes feitos por cineastas negros, gays, indígenas, mulheres, no Brasil vemos cada vez mais produções por esses cineastas e também vemos uma atenção diferenciada do poder público ao criar editais que premiam ou favorecem essas produções. Além disso, os movimentos negro, feminista e indígena, entre outros, têm conseguido, por meio da internet, uma exposição de suas ideias e práticas que antes não conseguiam em escopo e profundidade. O resultado é que as discussões sobre gênero, raça, classe, etnia, religião e política tomam outras formas e caminhos, atingindo de novas maneiras pessoas que não tinham sido expostas a essas conversas e práticas. Cineastas e filmes são cada vez mais pensados na ótica de seus efeitos de representação, representatividade, lugar de fala, e em termos de linguagens e suas (re)produções de formas de opressão ou resistência em relação a grupos oprimidos. Com isso, a profusão de filmes no Brasil nos últimos anos sobre temas ligados a grupos oprimidos é notável, e só não avança mais por conta das estruturas de desigualdade sociocultural e econômica do Brasil.

\subsection{Alguns documentários e suas intervenções}

O curta-metragem Leve-Me Pra Sair começa logo com a questão feita a jovens que se identificam como LGBTs: Qual a sua opção sexual? Após alguns responderem, um terceiro vem com a reflexão levada de volta ao entrevistador: Opção? Segue-se daí que muitos jovens questionam se o que eles vivenciam como sua sexualidade é uma opção ou não, o quanto esse discurso da sexualidade como opção foi-lhes ensinado e dado como óbvio, mas que é questionável, pois ali muitos dizem que nunca escolherem

\footnotetext{
${ }^{34}$ Temer recua e decide recriar o Ministério da Cultura. Fonte:https://oglobo.globo.com/cultura/temer-recua-deciderecriar-ministerio-da-cultura-com-marcelo-calero-19351863

${ }^{35}$ Bolsonaro extingue Cultura e Esportes e deixa ministérios de Mulheres e Direitos Humanos para depois. Fonte: https://www1.folha.uol.com.br/poder/2018/11/bolsonaro-extingue-cultura-e-esportes-e-deixa-ministerios-de-mulherese-direitos-humanos-para-depois.shtml.

Sem patrocínio da Petrobras, diretores e produtores temem desmonte do cinema. Fonte: https://entretenimento.uol.com.br/noticias/redacao/2019/02/14/sem-patrocinio-da-petrobras-diretores-e-produtorestemem-desmonte-do-cinema.htm
} 
serem gays, lésbicas etc., que somente cresceram e se perceberam assim. O filme portanto, logo de início, confronta um discurso sobre o Outro LGBT, deixando que esse Outro responda ao dominante. Numa segunda pergunta, o filme mostra os personagens respondendo a como preferem ser categorizados: como gays, lésbicas ou outros nomes. Alguns colocam que gostam de ser chamados de gays (mesmo que o fenótipo seja mais feminino) e outros que preferem sapatão ou lésbica. A preferência de todos ali é pelo modo como o nome reflete melhor um estado de ser afirmativo de si mesmo, ou depreciativo. Alguns acham que lésbica soa mal, outros que é uma autoafirmação politizada, pela visibilidade de uma comunidade lésbica. Outro, ressoando os preconceitos com os quais as palavras homossexual, bicha e viado são usadas, não gostam de nenhum desses termos, e diz: "eu prefiro que fale gay”, mostrando que para esse sujeito, a palavra gay conseguiu um destaque, uma menor violência e maior abertura à aceitação.

Alguns personagens falam como o contexto de uso das palavras, mesmo aquelas que eles aceitam usar para eles mesmos, incomoda às vezes se feito por uma pessoa que obviamente é preconceituosa. A sexualidade também é tratada por um entrevistado como apenas mais uma faceta de sua identidade, talvez até com pouca importância para ele, enquanto outra diz que é importante, determina em parte a forma como as outras pessoas lidam com ela, e isso tem efeitos em sua vida. O filme segue contando histórias sobre “sair do armário” ou revelar-se gay ou homossexual ou outro para família e amigos e outros. O filme fica apenas naquele mesmo plano para todos os entrevistados, todos eles da mesma faixa etária e provavelmente residentes da mesma cidade. A experiência de ser LGBT portanto pode ali estar reduzida tanto em termos de idade, quanto de classe e localização.

Muitos outros filmes têm sido feitos sobre questões LGBT, no Brasil e no mundo. A tecnologia digital, junto a novas autoafirmações de grupos oprimidos, levou a produções que colocam as discussões sentidas por esses grupos em primeiro plano nos filmes. O valor educativo, pedagógico, desses filmes é muito grande, tanto para pessoas que não são a princípio LGBT, para que se questionem sobre seus preconceitos e ações, quanto para LGBTs que podem se identificar nos assuntos e situações pelas quais passam os personagens dos filmes. Leve-me Para Sair é um filme que tem várias vozes de Outros sujeitos filmados que se declaram LGBTs, e nenhuma delas atinge dominância sobre as outras. A voz que domina, portanto, é a da produção e montagem, que optou por planos únicos e iguais em composição para todos os entrevistados, filmados em primeiro plano. 
Há apenas a verbalização de autoentendimentos e vivências pessoais, que se desdobram em vivências coletivas ao serem confrontadas pela montagem umas com as outras. Há apenas aqueles que são os Outros da sociedade dominante heterossexista falando. Não há recurso a especialistas ou a pessoas preconceituosas para que falem. Não há o “outro lado” que fala no filme, pois esse outro lado é o do preconceito e da opressão. O dispositivo do filme, todo o conjunto de decisões sobre quem filmar, como filmar, quais perguntas fazer, tudo parte da opção de fazer ressoar as vozes de Outros da sociedade dominante, e silenciar as vozes que já tem espaço demais, as vozes do preconceito. Seria uma opção o filme confrontar mais de frente as formas de opressão contra LGBTs? Seria uma opção fazer outros recortes, no modo como a vivência do LGBT difere conforme a pessoa é de uma raça que não a branca e de uma classe social mais baixa? Seria se fosse outro filme, mais longo e com outros efeitos, pois ao confrontar a opressão trazendo-a para o embate direto dentro do filme, seria preciso dar conta de desconstruir as opressões em como elas são (re)produzidas nas relações, como vão além das intenções, e como impedem todos e não somente os LGBTs de terem uma vida melhor. Confrontar de frente as opressões é falar a partir da autoafirmação de uma voz libertadora, que não pode ser libertadora apenas para alguns, embora ela por necessidade priorize as vozes e vidas de quem é mais oprimido, numa visão interseccional e sempre em disputa, pois por mais que a ninguém pertença a régua da medição de opressões, algumas vezes é muito claro distinguir entre oprimidos, qual deve ser priorizado em escuta e ações, sem com isso criar hierarquias finais.

Numa chave muito diferente, o filme A Negação do Brasil - O Negro na Telenovela Brasileira (Direção Joel Zito Araújo, 2000) retrata os estereótipos a que atores negros deram vida em papéis na telenovela brasileira. O filme traz muitas imagens de arquivo das novelas com os comentários críticos que apontam os estereótipos, realizados pelo diretor, ele mesmo negro e que traz sua vivência de receptor daquelas imagens desde sua infância. Há testemunhos individuais e em grupo das maneiras pelas quais certos papéis de personagens foram criados, e formas de resistência dos atores e atrizes negros ao que lhes era proposto e que sentiam como papéis estereotipados. $\mathrm{O}$ filme confronta diretamente os estereótipos como parte de discursos dominantes sobre o negro que, ao mesmo tempo que reproduzem, são eles mesmos formas do racismo. Um racismo que é estrutural, no sentido de que na vida brasileira realmente o negro está geralmente em posições subalternas, como empregada doméstica e outros serviços, ou como bandido, mas que ao ser reproduzido pelas mídias acaba pro reforçar esse lugar do 
negro na sociedade, ainda mais quando reforça estereótipos do negro como desonesto, burro, incapaz ou submisso, como fizeram as telenovelas.

O filme se ocupa, em primeiro lugar, de discursos dominantes, representados pelas telenovelas, para a partir da crítica abrir a conversa sobre raça e racismo, e representação e representatividade do negro na televisão. O que se constata, pelos trechos de novelas e pelos testemunhos de atores negros da Rede Globo, é que há poucos papéis para atores e atrizes negros no Brasil, apesar da audiência ser majoritariamente negra, e que os papéis são na maior parte das vezes estereotipados e, assim, reprodutores de preconceitos e do racismo tanto de atitude, quanto estrutural na sociedade brasileira. $\mathrm{O}$ filme se tornou um marco na luta de atores e atrizes negros e dos movimentos negros como um todo no Brasil, para que além da representatividade, isto é, da aparição de mais atores e atrizes negras, haja também maior qualidade na produção de representações sobre o negro nas telenovelas, minisséries, e filmes realizados no Brasil. A Rede Globo, nos últimos anos, passou a instituir grupos de estudo para a realização de alguns programas para qualificar suas relações com a comunidade negra, como resultado direto de pressões dos movimentos negros que se posicionam a cada papel estereotipado do negro apresentado, pois reconhecem a importância da representação do negro na maior rede de televisão e de comunicação do país.

A voz do Outro, nesse caso, é a voz de atores e atrizes negros, mas também abrange a voz dos negros no geral no Brasil, que é silenciada ou estereotipada nas telenovelas. O que a voz do documentário nesse filme faz é um confronto direto com discursos dominantes sobre o Outro negro, que o tornam um Outro da sociedade dominante branca que detém os meios de produção das telenovelas, e que é socializada em representações problemáticas e racistas sobre o Outro. Assim, nesse filme a voz do Outro é aquela que, para se afirmar, precisa necessariamente primeiro destrinchar o que lhe impossibilita de falar, de representar a si própria de maneira que não recaia na reprodução das estruturas e discursos dominantes que mantêm o negro numa condição subalterna no Brasil.

A voz do Outro, representada tanto pelos atores e atrizes negros quanto pelo diretor e seu comentário analítico, mas também pessoal, se torna uma só com a voz do documentário ao se concentrar nos limites impostos à participação dos negros na produção das representações de si na telenovela. Obviamente, o modo de recepção vai determinar o modo como a voz do documentário se dá, mas como o filme é um em que o diretor-comentarista e Outros entrevistados estão numa conversa na qual há um discurso 
que se coaduna e se confirma entre vozes. Mesmo que não tenhamos controle ou capacidade de análise de todas as formas possíveis de recepção desse filme, não há como deixar de vê-lo como uma obra em que as vozes dos Outros e a voz do documentário são complementares, em que as vozes de atores e atrizes negros não servem apenas para ilustrar o que diz o diretor-comentarista, mas trazem novas perspectivas e atributos ao filme. Não é, desse modo, um filme que apenas confirma uma tese do diretor, mas traz nas várias vozes de Outros perspectivas específicas, que não necessariamente ou não muito facilmente podem ser resumidas numa grande tese, pois essas perspectivas são únicas e diversas em suas vivências.

A vivência do diretor-comentarista é a do espectador que vive os efeitos das produções de telenovelas, enquanto atores e atrizes trazem testemunhos que são em parte comuns a outros do mesmo ramo, em parte são histórias únicas e que não se explicam apenas por estruturas sociais, são histórias que também têm sua singularidade pois não se repetem nunca igualmente. Por exemplo, a escolha do ator branco Sérgio Cardoso para interpretar um protagonista negro na novela A Cabana do Pai Tomás, tendo o ator que se pintar de negro para atuar, num último blackface ${ }^{36}$ da telenovela brasileira, "provocou a primeira polêmica pública sobre a questão racial na televisão brasileira”, como comenta no filme o diretor. O documentário mostra que os atores e atrizes negros não eram apenas vítimas das formas de representação do negro, e muitas vezes resistiam a elas. Mas a instituição da Rede Globo era quem pré-definia os papéis possíveis aos negros, então seria nesse nível que os movimentos negros vieram a debater e influir com certo grau de sucesso nas próximas novelas e programas da Rede Globo.

O “modelo sociológico” tinha como um dos seus legados centrais os filmes sobre as "vítimas” da sociedade ou de alguma instituição. Muito se criticou tal legado por conta de seu enfoque, em alguns filmes, na criação de personagens vitimizados por algum sistema social. Mas isso em si não relega um filme a esse legado, ou não deve ser um signo exclusivo para caracterizar um filme como “sociológico”. Muitas vezes, um Outro é vitimizado e é dessa forma que precisa ser representado, especialmente quando caracterizá-lo como vítima é fundamental para ações judiciais e institucionais ligadas ao Estado. O filme A Guerra Invisível (Direção Kirby Dick, 2012) conta a história, até então pouco falada, das soldados mulheres no exército dos Estados Unidos que sofrem abusos sexuais e estupros nas mãos de colegas soldados e de seus superiores. Por conta do

\footnotetext{
${ }^{36}$ Blackface é uma prática de teatralização de estereótipos de negros, geralmente realizada por pessoas de raça branca. Ao se pintar de negro, a pessoa que faz a teatralização veste caricaturas que denotam racismo.
} 
sistema, elas não podem se mobilizar, não tem poder para tal, pois a pessoa para a qual institucionalmente deveriam reportar abusos é muitas vezes a mesma que as abusou ou estuprou. Por isso o filme, como prestador de testemunho a essas vítimas, foi essencial para que as instituições envolvidas tivessem que dar uma resposta. Como elas não tinham voz dentro da instituição, a luta de advogados e de movimentos feministas que foram instrumentalizados pelo filme alcançou mudanças em políticas públicas para enfrentar o problema. A prática dentro das Forças Armadas era fingir que nada havia acontecido e de causar o silenciamento das mulheres vítimas. A estratégia de mostrar o filme aos públicos que precisavam vê-lo, especialmente dos ministérios de defesa e instituições ligadas às Forças Armadas, foi fundamental para os efeitos sociais pretendidos. O filme venceu diversos prêmios, entre eles o do Público no Festival de Sundance em 2012 e também o de Impacto pela BRITDOC Foundation em 2013.

O filme Espero Tua (Re)Volta (Direção Eliza Capai, 2018) narra, pela voz de três estudantes ativistas, as lutas de estudantes secundaristas contra reformas propostas pelo governo do Estado de São Paulo que visavam fechar salas de aula e escolas pelo Estado, e como essas lutas estavam ligadas a outras lutas anteriores pelo transporte público, e se desenvolve para lutas posteriores pela educação no Brasil como um todo. Os comentários de três estudantes intencionam pontos de vista particulares ao filme, ao mesmo tempo em que fazem a ligação de cenas na montagem. Os comentários também esclarecem sobre suas escolhas e posicionamentos tanto perante as histórias a contar, quanto sobre a interpretação dos fatos, assim como sobre o modo a contar: a obra deixa claro porque escolhe duas personagens femininas e apenas um masculino, pois o movimento era composto em número maior por mulheres, assim como escolhe personagens negros, pois a dinâmica dos próprios movimentos estudantis se pautava tanto pela alternância de vozes em assembleias, quanto pela qualificação do lugar de fala de cada voz, como voz de mulher, de mulher negra periférica etc. Essa dinâmica é trazida para a própria construção da narração comentada feita pelos três personagens, que são também os narradores do filme, e ao final ficamos sabendo que eles co-escreveram essa mesma narração.

A linguagem adolescente provavelmente terá efeito sobre a recepção por adolescentes, pois a narração em primeira pessoa é comum a filmes teen norteamericanos, que chegam em massa ao Brasil. Essa narração também aproxima o espectador do ponto de vista dos adolescentes. O filme ainda não estreou no Brasil, porém temos como dizer que já se apresenta como importante veículo de contra-memória 
e de ressonância de vozes de resistência contra o modelo neoliberal vigente desde o golpe realizado por Michel Temer e da eleição judicializada pela prisão de Lula da Silva, que deu margem para a vitória de mais um governo neoliberal, que vem atuar pela precarização daquilo que é público em favor do privado. Nesse sentido, ao ser lançado no Brasil em 2019, esperamos que o filme possa ser uma nova referência para os estudantes que virão a ocupar as escolas públicas daqui para frente e têm consigo o registro organizado dessa história de vozes de resistência. Diferentemente do YouTube, em que as vozes aparecem mas sem uma continuidade histórica e sem uma aproximação narrativa que permite maior empatia e identificação, o valor do filme documentário é justamente o de provocar uma aproximação com essa história como se ela se desenvolvesse no aqui e agora do espectador, atualizando-o para a continuidade de lutas. Assim como os estudantes secundaristas foram influenciados por um documentário sobre as ocupações de escolas no Chile, espero, realmente, dado o estado atual de nossa política, que o documentário nos impulsione novas (re)voltas. O filme ganhou o prêmio da Anistia Internacional no Festival de Berlim e a diretora também realizou um protesto $^{37}$.

Como podemos ver pelos conceitos e exemplos trazidos ao longo da tese, não é possível a instituição de manuais de inserção de vozes de Outros no documentário, especialmente se visamos efeitos específicos. Se buscamos ser Aliados de Outros, nosso “manual” de ações é feito na prática da realização do filme, ao buscar no Outro mesmo a validação de nossas escolhas de representação e de análise de seus possíveis efeitos. Por mais que tentemos fazer o melhor, nossa cumplicidade com opressões é inevitável, inexorável. Sempre vamos falhar em algum ponto, ao tentar incluir vozes e vidas de Outros num documentário. Pois não temos como trazer a vida como um todo para dentro de um filme. Um filme é sempre um recorte, e desse modo é sempre silenciamento de vozes. O que alguns filmes nos mostram, no entanto, é que apesar desse silenciamento, há sim outras vozes que se apresentam no documentário e que ressoam, produzindo efeitos, muitos deles pretendidos pelos seus produtores, outros que escapam a seu controle, pois o controle da recepção é uma ilusão. O filme, quando posto no mundo, toma uma vida própria, determinada somente em parte por quem o criou. Isso não tira, contudo, a responsabilidade de quem cria. Pelo contrário, por ser perigoso colocar criações culturais, especialmente aquelas que questionam e invocam espaços para quem

\footnotetext{
${ }^{37}$ Fonte: https://www.revistaforum.com.br/diretora-brasileira-eliza-capai-ganha-premio-em-berlim-e-protesta-contragoverno-bolsonaro/
} 
tem pouco poder e recursos, pouco espaço de articulação de suas vozes, é que a responsabilidade ética de seus produtores deve ser pensada com maior importância, relevância, urgência.

\subsection{A ética e política da voz do Outro na voz do documentário}

No livro Introdução ao Documentário, Bill Nichols pergunta: “O que fazer com as pessoas? Formulada de outra maneira, a pergunta é "que responsabilidade têm os cineastas pelos efeitos de seus atos na vida daqueles que são filmados?” A pergunta é inerentemente ética. Mas o que é ética no trabalho do documentário? Quando é que o cineasta deve começar a considerar questões éticas? Se filmes têm efeitos na vida dos sujeitos filmados, quando é que o trabalho de considerar a ética tem lugar?

Talvez a questão esteja mal formulada. Pois se a ética entra somente depois que um filme já teve início, que um processo de construção de um filme está em curso, então temos uma decisão - política - feita de somente considerar o Outro sujeito filmado e o público depois que a construção da representação já está em movimento. A ética como prática da justiça não se inicia, é uma prática contínua sem começo nem fim. É a prática da existência de um Outro: pois sem “esse 'deixar-ser' de um (Outro) existente como algo existindo fora de mim na essência do que é (primeiro em sua alteridade), nenhuma ética seria possível” (DERRIDA, 1978, p. 138). Desse modo, como uma prática contínua da justiça em relação ao Outro, a ética é muito mais do que apenas a prática de minimizar efeitos prejudiciais de documentários. A ética no documentário é considerar que como prática social relacionada a Outros, a produção de filmes precisa estar atenta desde seu início, desde sua concepção, às suas relações com Outros. Pois de outra forma, estamos falando apenas de normas, de normalização do trabalho do documentário. Atingir manuais de ética no documentário, reduzir a ética a algumas normas a seguir, é tanto reduzir o potencial do documentário, quanto reduzir o Outro a um objeto cognoscível. A normalização da ética no documentário produz uma reificação de ideias como primárias a ações no mundo, e o Outro como efeito de controle do cineasta. O Outro passa a ser aquele que precisa ser respeitado, numa relação que impõe ao Outro o seu lugar na representação, não permitindo de antemão que o Outro possa de fato se tornar criador da voz do documentário. O cineasta dificilmente sai do seu papel, de personagem-diretor. E para manter-se nesse papel, precisa que o Outro tenha também um papel, que o cineasta lhe incute de antemão, sem muitas vezes ouvir do Outro se este quer ser personagem, ou 
se quer outro filme. Os limites ao Outro quanto à sua atuação são baseados numa política da representação ${ }^{38}$, que em grande parte dos documentários, mantém o diretor do filme na posição da definição do modo como o Outro sujeito filmado vai ser representado. Ética é fundamentalmente sobre relações e seus efeitos, e no documentário essas relações, muitas-vezes já desiguais, onde quem define sobre a adequação, meios, propósitos, estratégias, técnicas, é raramente o Outro sujeito filmado, são relações que tendem a reproduzir desigualdades entre quem filma e quem é filmado. Isso ocorre tanto no nível de relações face a face, quanto no de reprodução de desigualdades sociais estruturais. Ao fazer filmes, a responsabilidade é imensa para quem os faz. Não há escolha de não lidar com os problemas do Outro, com o mundo vivido do Outro sujeito filmado. As escolhas de quem filmar, como filmar, como finalizar e fazer circular um filme, são escolhas políticas. O que essas escolhas demonstram é o tipo de intervenção que um cineasta está a produzir (e isso é mais do que suas intenções ou motivações, porque sua intervenção vem em parte de sua bagagem cultural, de sua formação e atuação no mundo, mesmo que em parte inconsciente). Essas escolhas sobre a produção de um filme são políticas. Elas refletem o quanto um cineasta quer estar junto de Outros na construção do mundo vivido, ou como busca se afastar. Mas a relação com Outros, e a produção de efeitos sobre a vida de Outros, é inescapável na produção do documentário.

Trabalhar com a voz do Outro por efeitos vai além da denúncia, ou da observação antropológica, da descrição da vida do Outro enquanto alteridade idealizada. Pois apenas a denúncia, colocando o Outro como um ser que vive numa realidade problemática, tende a reproduzir os discursos dominantes sobre o Outro. No filme Falcão - Meninos do Tráfico (Direção MV Bill, 2006), vemos a representação de meninos envolvidos para as drogas e o tráfico. As vozes dos meninos que ouvimos, enquanto vemos seus rostos mascarados, relatam aquilo que são perguntados, como para confirmar que o tráfico é definidor de suas vidas. Podemos ver que são meninos negros, mas não há uma leitura racial feita no documentário. Podemos ver que são meninos das favelas, mas não há uma leitura das favelas. Para moradores das favelas, talvez o filme seja relativizado e os meninos do tráfico, vistos realmente como meninos, crianças. Nessa política da representação onde é dado que o espectador sabe o que é a favela, a leitura dominante da classe média e rica branca é a de que aqueles são meninos perdidos para as drogas e o

\footnotetext{
38 Usamos o termo política da representação para nos referirmos à conjuntura da produção de representação no aspecto do controle dos modos e dos meios de produção da representação e os efeitos resultantes sobre os sujeitos que detém esse controle e que impõem sobre a representação suas marcas.
} 
tráfico. Quem mora no Brasil já deve ter ouvido esse que é um dos discursos dominantes sobre o Outro envolvido com drogas e tráfico. Como sabemos? Filmes cegos para o racismo e o classismo, os reproduzem. A história dos meninos é trágica e sem saída no filme, o que acaba por reproduzir o discurso dominante, que pensa precisamente dessa forma trágica. Escrevendo a respeito de outros filmes sobre violência típicos dos documentários dos anos 1990 no Brasil, como Notícias de Uma Guerra Particular (Direção João Moreira Salles e Kátia Lund, 1999) e Ônibus 174 (Direção José Padilha, 2000), afirma Esther Hamburger (2005, p. 313) que podemos “enriquecer o debate sobre como representar a violência e a pobreza no Brasil sem reproduzi-las.” Isso passa por como criar uma política da representação que traga o Outro sujeito filmado para influir na produção de sua representação, e mais: passa pela atenção aos efeitos da representação sobre todo o conjunto de Outros afetados por ela. Pois ao representar um Outro tragicamente, se reproduz a ideia do destino como fatal a Outros que possam ser identificados como o Mesmo do sujeito filmado no discurso dominante.

Filmes sempre vão produzir significados e representações múltiplas e contraditórias. Michael Moore, em uma cena em Tiros em Columbine leva dois dos meninos que tomaram tiros no massacre, tiros de balas compradas em lojas K-mart, à sede da K-mart e mostra os meninos com suas marcas de balas a alguns representantes da empresa. Os dois estão ali, na frente da representante, um deles em cadeiras de rodas, como efeito do massacre. A cena é impactante. São os dois meninos que falam e justificam a necessidade das lojas K-Mart pararem de vender munições. Eles são mal recebidos pela empresa. Um dos meninos dá a ideia de ir a uma loja K-Mar próxima e comprar todas as munições de lá. Eles levam essas munições de volta à sede da empresa, acompanhados por vários veículos de mídia, e entregam as balas de volta. Isso leva a empresa a dar no mesmo ato uma declaração à mídia ali presente de que a K-Mart não venderia mais munições para revólveres em até 90 dias. Segundo diz Moore, esse resultado é mais do que ele e os meninos pediram. Esse impacto direto do filme é impressionante, e se dá em grande parte à presença de Michael Moore, já muito conhecido à época. Por outro lado, ao circular, o filme também é assistido por muitos jovens que passaram a idolatrar a ação dos meninos que foram os assassinos em Columbine. A ação do massacre vira um exemplo para muitos jovens. Os massacres que aconteceram no Brasil nas cidades de Realengo em 2011 e em Suzano em 2019 foram 
realizados por meninos que segundo informações de amigos próximos ${ }^{39}$ e de investigações policiais, tinham o massacre de Columbine como exemplo a ser seguido ${ }^{40}$. Teria o documentário de Moore ajudado a influenciá-los? Se o fez, não o fez sozinho. No caso do massacre de Suzano, por exemplo, os meninos que cometeram o assassinato eram fãs de Slender Man (Direção Sylvain White, 2018), um filme de ficção em que um monstro ataca uma escola, e de videogames de violência. Todas essas produções culturais se ligam ao ato cometido por eles, de um modo ou de outro. Filmes provocam sensações, e em algumas pessoas o desejo de realizar essas sensações na vida. A aura e sensações, afetos, materialidades que um documentário é capaz de realizar, são impactantes emocionalmente e se ligam às contingências da vida de quem assiste. Mas assim como os efeitos de filmes são incontroláveis, eles incluem os efeitos contrários às intenções de seus realizadores. Não podemos medir a proporção do impacto de filmes em meio a outras contingências, mas quando temos dados que mostram poder haver uma relação, é prudente também deixar aberta a possibilidade de que um filme pode ter ajudado a produzir justamente o que queria criticar.

A ética do documentário na representação do Outro deve sempre pensar em que nível pode estar ajudando a reproduzir opressões sobre Outros. Mas para isso, é preciso que a ética seja primeiramente uma relação entre iguais, uma condenação do Outro junto a quem se quer ser aliado não pode ser dos efeitos dominantes de um filme. Se isso ocorre, é porque politicamente o filme escolheu errado seu alvo e não parte de um lugar de afirmação do Outro em sua diferença. A representação do Outro que reproduz opressões é uma forma de violência. Em certa medida, isso está fora do controle do cineasta. Pois como já afirmamos, a voz do documentário vive a partir do momento de sua escuta, a partir do momento em que pessoas assistem a um filme, é só assim que um filme vive. E não é possível prever todos os efeitos da vida do Outro, quanto menos de um filme na vida de Outros.

Nesse dualismo estabelecido pelo discurso dominante sobre a voz do Outro na voz do documentário, o que fica de fora é a ética e a política do documentário. Impera o jogo de identidade/alteridade como momentos de consciência, como imagem ou narrativa, e não como processo social e histórico com seus efeitos. Para pensar a ética e a política do documentário, é necessário pensá-lo como (re)produtor da cultura e da

\footnotetext{
${ }^{39}$ Uma reportagem exibida no canal Record em 13/03/2019 mostrava um amigo dos meninos que realizaram um massacre na cidade de Suzano dizendo que eles tinham Columbine como exemplo.

${ }^{40}$ Fonte: https://www.vice.com/pt_br/article/qvya87/nos-chans-ja-se-celebra-o-massacre-na-escola-desuzano?fbclid=IwAR2aYVu1_dBDLfY6kjpf3tT9nZSmpa1-Hd0U6M1tBP4oPxMNWJnLhp6zdOY
} 
sociedade. É necessário pensá-lo em sua materialidade, em seus afetos (re)produzidos, em como sempre ele opera enquanto discurso sobre Outros e sobre o mundo que é. Discursos também são práticas sociais, não ficam delimitados à arte enquanto uma dessas práticas. Muitos documentaristas podem não querer se comprometer com o Outro, por isso o mais fácil pode ser para eles acreditar ser impossível representar a voz de Outros. Mas eticamente falando, se você trabalha como cineasta com vozes de Outros, ou com representações de Outros, ou com representações que tenham efeitos nas vidas de Outros, sua cumplicidade com os Outros e com o que lhes acontece estará dada. Não há escolha, quando se fala de ética, sobre ter ou não efeitos nas vidas de Outros. A falsa escolha nesse sentido é uma posição política com efeitos. Fernão Ramos anuncia que

A antropologia visual do final do século XX possui sua própria visão da ética do documentário, centrada na desconstrução da subjetividade da voz que enuncia. (...) Não há porque deixar de supor que a visão ética dominante na antropologia visual contemporânea terá um dia sua validade histórica ultrapassada, na mesma medida em que a ética de Flaherty representa hoje para muitos uma visão de mundo deslocada.” (RAMOS, 2008, p. 33).

Talvez, apenas talvez, a nova ética do documentário possa ser a ética da relação com Outros como inescapável, como tendo que levar ao questionamento das relações estabelecidas entre cineastas, sujeitos filmados e públicos. Onde o que importa acima de tudo é que, por essas relações, se visa chegar a efeitos que - embora não garantidos estão baseados em relações de aliança. Que a nova ética do documentário possa permitir que se reconheça o potencial dos filmes em fazer ressoar vozes de Outros onde estas demorariam mais ou nunca chegariam, ressoando particularmente onde precisam fazê-lo para alcançar melhorias de vida para Outros. A voz do Outro na voz do documentário não pode ser um fim em si mesmo, o fim de produzir filmes que apenas entretêm. Estes devem continuar a ter espaço, mas se esse espaço é resultado de uma política da representação baseada na aliança, onde a prática e os resultados do documentário não venham a (re)produzir mais opressões e violências do que o contrário. Uma ética do documentário produzida na relação com o Outro sujeito filmado é a da responsividade à alteridade, na voz do Outro como condição da política da representação, onde os efeitos de filmes na vida de Outros, mesmo que incomensuráveis como o Outro é 
incomensurável, sejam mesmo assim o centro do trabalho do documentarista. A ética do documentário, longe de ser baseada na moral julgadora de Outros, é orientada para a ação social, para direcionamentos a efeitos pretendidos. A renovação da ética no documentário já está acontecendo, e ela está centrada, por diversos meios e estratégias, na produção da voz do documentário como subserviente à voz de Outros que podem co-criar a representação de si mesmos, desafiando discursos dominantes sobre si e Outros, afirmando sua voz a quem tiver disposição e condições de ouvir. 


\section{CONSIDERAÇÕES FINAIS}

\section{Para quê serve a representação do Outro?}

Todo filme documentário é político, pois todos, para serem realizados, necessitam de pré-concepções que incluem escolher quem filmar, como filmar, onde filmar e como contar uma história. Os vários legados do documentário trouxeram diversas vezes à tona a discussão sobre as relações entre os filmes e o mundo vivido. Os discursos sobre o documentário em sua relação com Outros sujeitos filmados e os propósitos envolvidos variaram conforme o tempo, saindo do primeiro legado dualista dos embates entre Flaherty e Grierson, até o Cinema Direto e Cinema Verdade, e à “ética modesta” (RAMOS, 2008) dos documentários subjetivos ou da “verdade do filme” em resposta ao modelo sociológico. Em todos esses, temos as discussões sobre métodos de trabalho como definidoras da verdade possível aos filmes. Flaherty e Grierson acreditavam poder representar a realidade, só diferiam nos Outros que representavam. Cinema Direto e Cinema Verdade acreditavam no dispositivo acima de tudo, que no Cinema Direto se traduzia na não-intervenção, visando assim aguardar que o público tirasse suas conclusões sozinho, enquanto no Cinema Verdade acreditava-se ser possível produzir a “verdade do filme” por conta da intervenção mesma do processo de filmagem, num percurso que ainda tinha no Outro um participante mais ativo da "verdade do filme". Enquanto o modelo sociológico explicava o mundo, o modelo da "ética modesta” (Idem) evita qualquer explicação que possa ser considerada generalizante, e para isso tem evitado também o Outro como aliado, como cocriador de suas representações, assim como fazia o modelo sociológico. Pois só é cocriador, o Outro que participa da política de representação do documentário, ativamente, como aliado do cineasta. Nos jogos de dualismos dos legados do documentário, sempre há um plano em comum no qual o jogo se torna possível.

Na atualidade, a política da representação que se baseia em uma negação ao modelo sociológico, em uma reatividade, repete esse mesmo modelo ao não incluir o Outro como aliado na produção. Ao não querer criar representações de realidades socioculturais, como faziam Flaherty e Grierson; ao usar o dispositivo como definidor último e majoritário de filmes, e não apenas como incitador do processo ; ao evitar o modelo sociológico que falava sobre Outros num gesto reativo de recusa à representação do Outro, acabou por transformar o campo do documentário num espaço que, embora 
contestado, domina o discurso de que representar o Outro é indesejável porque impossível. O que é interessante, já que foi a própria construção reativa de um discurso junto a filmes também reativos ao modelo sociológico, que consagraram a ética dominante do documentário como apolítico, o que gerou novamente a valorização de filmes que produzem rejeição a qualquer forma de representação de realidade que seja politizada em torno de movimentos de Outros no mundo que visam efeitos sobre esse mundo. O discurso dominante coloca que filmes não representam realidades, logo dispositivos criam realidades do filme, com o fim de produzir bons personagens. Temos a verdade do filme. Não temos nada contra esse modo de produzir. O que estamos defendendo é que o modo dominante de discursar e produzir filmes documentários hoje, ao menos no Brasil, é baseado numa reatividade a toda a história dominante do documentário, ao mesmo tempo em que é a criação, como toda reatividade, de um espaço alienado de produção que se distancia do mundo para que filmes sejam pensados e produzidos a partir dos cineastas e, principalmente para outros cineastas, pela arte desinteressada no mundo e nos Outros, porque interessada apenas no que lhe interessa. Os interesses dos Outros, nos discursos e práticas hoje dominantes no Brasil, são secundários, quando muito, ao interesse da arte, que é o interesse das elites e dos cineastas e teóricos do cinema. O documentário, para ser mais relevante novamente, precisa ser valorizado onde é mais potente: na (re)produção e circulação de vozes de Outros oprimidos e subalternizados. Novamente, não estamos a propor uma hierarquia. Estamos apontando que há uma hierarquia estabelecida por discursos e práticas do documentário hoje como arte acima da política.

O pós-modernismo é caracterizado por uma recusa a totalizações. Nessa recusa a representar o Ser, o Sujeito, a Verdade, no entanto, temos ainda a proposição de verdades que se colocam como parciais. A crítica pós-moderna ao Self unitário e essencialista, o sujeito da modernidade, abriu novas possibilidades de agência, novas possibilidades de crítica da representação. Por outro lado, ao rejeitar a representação do Outro como agente da cultura e da política, justamente no momento em que muitos Outros estão produzindo documentários, cria-se uma barreira para a escuta do Outro. Se antes tínhamos dificuldade na representação do Outro por conta de discursos e práticas dominantes que circulam em vários meios, hoje temos uma barreira a mais no documentário, em que uma abertura à conversa sobre “o que [Gayatri] Spivak denomina 'essencialismo estratégico' e o que [Stuart] Hall chama de 'necessidade ficcional do fechamento arbitrário’” (STAM e SHOHAT, 2005, p. 404-405) ficou difícil de se alcançar. Pois os documentários são 
julgados como essencialistas ou sociológicos, mas devemos atentar aos porquês das escolhas de certas representações do Outro sem considerar para a possibilidade do Outro preferir esse modo de representação porque visa efeitos específicos, e não porque acredita que só exista uma verdade verdadeira.

Assim como os discursos dominantes sobre o Outro agem de modo dualista, colocando o Outro geralmente na posição inferior, também os discursos dominantes sobre o documentário escolhem um Outro em relação ao qual se colocam como oposição binária e em superioridade moral. O moralismo impede qualquer ética na relação com o Outro, pois a instituição de um modo correto ou verdadeiro de fazer documentários coloca-se, assim, acima de uma avaliação de efeitos pretendidos. Fazer documentários a partir da posição moralista, da maneira certa de se fazer, impede a ética, pois a ética só se produz da relação com Outros, e é impedida se se parte de um modelo qualquer, mesmo que o modelo seja apenas uma reatividade, um não fazer desse modo ou daquele outro. Temos desse modo, no documentário, a dominância de políticas da representação que impedem uma ética do documentário. Pois ética não é a criação de dogmas, a moral sim. E toda moral está ligada a dominâncias de verdades sobre o mundo e os Outros.

Buscar a ética no documentário seria nos determos sobre o legado do documentário como engajado na produção da representação do Outro, nos termos desse Outro e de suas comunidades. Desde Flaherty passando por Rouch, pelo Cinema Direto e pelo Cinema Verdade, documentaristas buscaram o ponto de vista dos sujeitos filmados. Os graus de participação do Outro nas produções de filmes variaram, bem como as estratégias e técnicas utilizadas. No entanto, muitas vezes o ponto de vista dos sujeitos filmados foi apenas um meio para a realização de produções que não partiram do Outro, nem de modos de aliança com Outros que permitiriam a esses escolher o que filmar, por que e como. O Outro foi tratado, assim, na história do documentário, como fundamentalmente despolitizado, como um ser que não tem participação e não é inserido como produtor dos efeitos dos filmes. O Outro, desde os primórdios do documentário, foi tratado dominantemente como um meio para os fins dos cineastas. Desse modo, o cinema documentário trouxe, desde seu início, potencial para ser realizado sobre Outros e com Outros, e nesses dois as variações existem. Pois fazer filmes sobre Outros ou com Outros não são necessariamente polos opostos ou extremos, podem ser o mesmo processo inclusive, mas é justamente esse pensamento que é não-dominante. No discurso dominante hoje, é quase impossível pensar em fazer filmes sobre Outros e com Outros, onde os Outros como co-criadores partilham de todo o processo no filme. No entanto, 
apesar de todas as críticas ao legado de falar pelo Outro, ainda pouco se produz filmes com Outros, ainda perdura o fazer filmes sobre Outros, pois mesmo os filmes que rejeitam tipificações e generalizações são como efeito de seus dispositivos, modos e meios de produção que ficam somente nas mãos dos cineastas, filmes que, para além das intenções de seus realizadores, são sobre Outros.

Quando Outros dos discursos dominantes passaram a se auto-representar, ou a representar sujeitos de suas comunidades, vimos surgirem produções que trouxeram um confronto a discursos dominantes tanto no modo da produção de vozes de Outros, quanto nas próprias construções de narrativas e de imagens. Cineastas queer, negros e de comunidades oprimidas confrontaram diretamente as representações dominantes sobre si. Questionando a univocidade de representações, não deixam de lidar com discursos dominantes sobre o Outro LGBT, negro, mulher. Questionam as (im)possibilidades de representação de Outros, mas não deixam de enfrentar as representações dominantes. Trabalham na tentativa de produzir efeitos, de romper com essas representações sobre o Outro no mundo vivido.

A maioria dos teóricos e documentaristas, atualmente, sabe que o documentário não é a reprodução da realidade, é sempre uma construção. Desse modo, o que divide teóricos e documentaristas, hoje, diz respeito à capacidade do documentário de, ao representar Outros e seus mundos vividos, intervir nas realidades vividas por esses Outros e suas comunidades. Tal divisão, ao menos no Brasil, parece ser entre quem acredita que filmes são ou devem ser apenas um aparato estético, no sentido de serem uma produção cultural desligada de anseios politizados para o mundo, e quem acredita que o filme documentário pode ser um instrumento de intervenção no mundo, mesmo que não haja garantias para isso.

As formas de representação de Outros, particularmente se esses são de comunidades oprimidas, carrega sempre o fardo de poder reproduzir dominação sobre Outros. Mesmo quando atua em confronto a discursos dominantes, essa possibilidade sempre está dada. Por não ser a origem dos discursos sobre Outros, por haver sempre representações dominantes que o antecedem, o filme documentário atua dentro de uma rede de discursos que lhe preparam o campo de possibilidades de representação. Não atentar para o campo de representações atuante sobre Outros é estar menos instrumentado e menos engajado na vida dos Outros.

Como documentaristas, temos que perceber nossas socializações em discursos e práticas dentro dos quais somos socializados, porém não apenas como realizadores de 
documentários, ou como pensadores. Temos que atentar para os modos de nossa socialização em legados de pensamento e prática que vão além da profissão, que nos formam como sujeitos. Pois nossos modos de pensar a nós mesmos e de pensar Outros é sempre resultado dessas socializações, seja porque as reproduzimos acriticamente, seja porque buscamos vias de rompimento. De todo modo, estamos sempre em conversa, em relação que pode ser mais ou menos reativa, já que podemos ser mais ou menos formados pela maneira como reagimos aos modos dominantes e aos modos subalternos de nos colocarmos em ação. Se nossa ação é pela inclusão de nós mesmos e de Outros nos modos dominantes, buscando aceitação, vamos reproduzir o dominante como ação. Se, por outro lado, o que buscamos é o rompimento com discursos e práticas dominantes, por conta de que essas limitam o pensamento e as possibilidades de vida, então ao romper não podemos apenas nos moldar pelo dominante, agindo reativamente, fazendo o contrário dentro de um sistema maior que fica sem ser questionado. Não basta reagir com um não à Voz de Deus como legado, ou a nenhum modelo no documentário. Se o que se quer é romper com discursos dominantes por eles criarem representações problemáticas que vivem no mundo de modos problemáticos, é nesse mundo, nos efeitos advindos de filmes em relação ao mundo, no modo como filmes vivem e produzem efeitos, que a avaliação de sua relevância e ressonância deve ser feita.

Nesta tese, buscamos compreender a efetividade do conceito de "voz do documentário” de Bill Nichols e acabamos por alargar o conceito, pois viemos a entender que a voz do documentário só vive ao ser ouvida e interpretada, necessita da recepção para existir como voz. Como apontam os estudos de recepção da comunicação, essa se dá de formas múltiplas e contraditórias, não podendo os significados serem fixados. No entanto, havendo discursos, formam também o modo de produção; o modo como os cineastas produzem, como decidem por construir narrativas, tende a constranger a voz do documentário - a produção é fundamental no resultante dessa voz, mas ela nunca é determinada pelos cineastas. O circuito entre produção-recepção é que vai realizar a voz do documentário e essa terá seus efeitos a depender tanto de cineastas e seus processos de produção, quanto públicos e seus processos de recepção.

Os modos de produção do documentário mudaram através dos tempos. Com isso, a voz do documentário também vem mudando. Em parte, por questões técnicas, tais como o advento do som e depois de outras tecnologias, em parte pelos novos modos de produzir ou de distribuir, mas muito se deu em decorrência dos discursos sobre o documentário, sobre o que um filme pode ou não realizar. Quando o documentário é 
tratado como meio de intervenção no mundo, isso influi não somente para a escolha de temas e sujeitos a filmar, mas também nos sentidos dados para o próprio documentário enquanto prática social, enquanto agir no mundo com Outros. Quando o documentário é tratado enquanto arte desvinculada de qualquer propósito que não sejam as artes propriamente, outros sentidos vivem através dele. Em um e outro caso, os sentidos produzidos o são a partir de discursos e práticas culturais estabelecidas. Porém, como demonstramos, os discursos dominantes - porque reproduzidos por documentaristas e teóricos do documentário dominantes no Brasil - carregam a concepção de que o filme documentário é arte, ou deve ser prioritariamente arte, no sentido de que não busca politizar-se e (re)criar mundos, ou afetar pessoas de modo a que se tornem Outras. Ou, ainda, que os Outros oprimidos e subalternos, que não se enquadram pelos discursos dominantes, possam flexionar os discursos e práticas, mudando-os para que o mundo se torne mais favorável a eles.

A voz do documentário sempre é ouvida de maneira múltipla. As maneiras múltiplas existem por conta dos modos de vida múltiplos de cada público, e da multiplicidade de vozes que atravessa cada sujeito. Nesse sentido, toda produção de um filme é um ato político, é um emaranhado de posicionamentos sobre relações de poder, saber, discurso e práticas sociais que podem se complementar ou se chocar, dependendo do público a ver, ouvir, sentir-se afetado. A voz do documentário é política, sempre. Não se trata de escolhas. Não existe arte não-mundana, não-atravessada por discursos e práticas sociais. A questão é: quão ciente da sua (falta de) politização são os realizadores de filmes? Quão engajados em praticar o documentário como intervenção que mapeia seus efeitos nos discursos e práticas sociais estamos? Ou estamos engajados em desengajar-nos, em buscar, por meio do discurso da arte por ela mesma, uma desresponsabilização por nossas escolhas de intervenção no mundo?

Nesse sentido, interpretamos a voz do Outro com viés mundano, politizado. Nenhuma voz existe num vácuo de poder e de discurso. Se não temos como impedir a politização, se todo filme será julgado quanto à sua representação do Outro, vale então refletir se a questão é tentar o impossível - evadir qualquer discurso dominante sobre Outros - ou encarar de frente, contestar, confrontar discursos nos seus interstícios, em que o dominante está presente porém é apontado e destrinchado em sua necessidade do Outro subalterno. Como nos ensinou Michel Foucault, não há discurso dominante que não tenha suas margens e limites, e esses se dão justamente no ponto onde Outros os resistem. Dessa maneira, para que um Outro possa ter alguma chance de ser ouvido, é 
preciso mostrar as margens, aqueles discursos orais, textuais, imagéticos onde o Outro resiste. Esses limites caminham, são fluidos, não estamos aqui a querer localizar o Outro de maneira fixa no tempo. Como a vida, um filme reflete seu tempo, deve ser assim, não há escapatória. Porém, ao tomar vida, um filme deve ser acompanhado em seus efeitos na vida de Outros, e quando necessário, deve morrer também de alguma forma, se vier a se tornar um fardo para Outros. Talvez essa angústia perante a possibilidade da morte de um filme, sobre a possibilidade dele não ser mais um ser a favor de Outros, faça muitos documentaristas se esquivarem da representação de Outros em mundos vividos. Pois um filme que se posiciona, que toma lados, pode errar, pode reproduzir o que critica - como todos podem - e isso é assustador.

A responsabilidade sobre a vida de Outros, mesmo quando parcial, assusta. Por que um documentarista vai querer se colocar a serviço de Outros, se pode fazer filmes que encantam multidões e não trazem cargas pesadas de responsabilidade? Por que escolher lutar por justiça, direitos humanos, meio ambiente, e não apenas fazer filmes que entretêm? Assim como ao fazer documentários, cineastas dizem sempre sobre o mundo, dizem sobre si mesmos também. Um cineasta que escolhe falar do mundo, de Outros oprimidos, não é melhor nem pior que outros. A diferença está em escolhas éticas e políticas, de qual relação com o mundo se tem ou se quer ter. Ou se pode ter. Pois como somos todos formados dentro de socializações de raça, classe, gênero, cultura, além de nossas trajetórias individuais dentro dessas, somos sempre em parte resultado dessas, e isso se expressa em nossas relações e trabalhos. Realmente, seria muito pedir a um homem branco privilegiado que produza filmes sobre grupos oprimidos e tenha a voz do Outro na voz do documentário como sua tarefa primordial. Ao mesmo tempo, fazer esse pedido é perigoso, pois dado que o homem branco privilegiado foi socializado a ouvir e agir no mundo de certas maneiras problemáticas, talvez seja melhor mesmo concordar com Eduardo Coutinho e não instigar esses a produzir filmes sobre Outros visando serem aliados desses. Talvez. São escolhas dentro de circunstâncias em parte pré-determinadas. Mas se concordarmos e reproduzirmos o discurso dominante de que documentários não podem representar a voz de Outros de maneiras a melhorar a vida de Outros, uma coisa é certa: estaremos menos atentos a possibilidades de melhorar nossas práticas.

A politização inerente a filmes, como produções culturais que são, nos fez ter proposto pensar a produção de filmes por meio da aliança entre cineastas e Outros sujeitos filmados. Essa Aliança, afirmamos, é um processo de construção partilhada sem fim, pois visa efeitos no mundo, e o filme apenas como meio para a produção de efeitos. 
O filme deixa de ser o fim, como é quando produções culturais são valorizadas como parte da (re)produção de uma sociedade. Sendo o fim algo além do filme, esse visto como meio de intervenção, as relações entre cineastas, Outros sujeitos filmados e suas comunidades, e diferentes públicos é que têm prioridade no pensamento e na ação da produção. Não se trata, aqui, de prover uma metodologia de trabalho, de produção de filmes, de relações. Muito pelo contrário. Se o que importa são as relações, e os efeitos possíveis por meio dessas, é no contexto específico de cada produção que se deve pensar nos processos de Aliança e o que significam. Não estamos aqui propondo que documentaristas deixem de fazer filmes que se pretendem despolitizados. Apenas apontamos que se trata de um discurso legitimador de práticas politizadas desde sempre.

A escolha é entre reconhecer a despolitização no modo como Outros são representados em filmes como personagens sem tecer relações para além disso, ou reconhecer nos Outros sua presença nos filmes não apenas como personagens deles mas como Outros que, ao serem representados, necessariamente produzirão efeitos diversos para si e para suas comunidades ou grupos aos quais estão ligados por nação, raça, etnia, classe, gênero etc. O Outro é incomensurável, mas ainda assim pesam sobre toda representação os discursos dominantes que atuam sem que tenhamos como evitar. Esses discursos e práticas dominantes, ao serem recusados na produção, retornam pela voz do documentário enquanto um filme circula e assim vive.

A produção de documentários onde se visa representar Outros é ética na medida em que essa produção visa ser Aliada desses Outros. Em circunstâncias nas quais a representação de Outros não é a intenção dos realizadores de documentários, os efeitos dos filmes ainda serão sentidos em relações com Outros. Como é que se pode avaliar efeitos de produções? Apenas em uma relação de aliança ao Outro mais afetado diretamente em suas possibilidades de uma vida melhor. Mesmo que não tenhamos todos os meios para avaliar os efeitos de sentido de documentários que representam Outros, deixar isso à mercê das circunstâncias pode ser catastrófico.

Quando não se tem aliados com os quais juntamos nossa voz, não temos bases para uma ética. Para termos uma ética do documentário, precisamos deixar o legado evolucionista na visão das artes e do documentário em geral, em que haveria “vanguardas” à frente e o passado sendo deixado para trás, para uma visão da pluralidade de modos de se fazer e de efeitos possíveis em cada modo, sempre escapando, em última instância, de nossa capacidade de controle pleno. Para termos uma ética do documentário, precisamos de uma política da representação em que os efeitos de representações são 
valorizados acima de estratégias e técnicas. Em que a voz do Outro na voz do documentário não seja apenas a criação de personagens para um filme, seja sempre criação de possibilidades de uma vida melhor para Outros. Pois se não é isso, se não trata de relações do mundo vivido, talvez não devesse se chamar documentário. Pois a ética no documentário é a prática de uma política da representação que coloca os efeitos dos filmes no mundo de Outros aos quais estamos em aliança acima dos filmes como fim. 


\section{REFERÊNCIAS}

AGUAYO, A. J. "Documenting Grassroots History as a Means to Social Change: 778 Bullets, community engagement and the legacy of rural civil rights”. In: NOVOTNY, L. (Ed.). Documenting the black experience: essays on African American history, culture, and identity in nonfiction films. Jefferson, North Carolina: MacFarland \& Company, 2014. pp.153-169.

ALCOFF, L. M. “The Problem of Speaking For Others”. Cultural critique. Winter, 1991-92. pp. 5-32.

ALMEIDA, S. O que é racismo estrutural. Belo Horizonte: Letramento, 2018.

ARAÚJO, J. Z. A negação do Brasil. São Paulo: Senac, 2000.

ASHCROFT, B.; AHLUWALIA, P. Edward Said. New York: Routledge, 1999.

ASHCROFT, B.; GRIFFITHS, G.; TIFFIN, H. (Ed.). The post-colonial studies reader. New York: Psychology Press, 1995.

AVELAR, J. C. “A câmera lúcida.” In: MIGLIORIN, C. Ensaios no real: o documentário brasileiro hoje. Rio de Janeiro: Beco do Azougue Editorial, 2010. pp.123148.

BAKHTIN, M. M. The dialogic imagination: four essays. Austin: University of Texas Press, 2010.

BERNARDET, J.-C. Cineastas e imagens do povo. São Paulo: Companhia das Letras, 2003.

BHABHA, H. K. O local da cultura. Belo Horizonte: Editora UFMG, 2001.

BHABHA, H. K. The location of culture. New York: Routledge, 1994.

BONOTTO, A. "Bill Nichols fala sobre documentário: vozes e reconstituições”. Doc On-line, n. 6, pp. 250-263, ago. 2009. Disponível em: www.doc.ubi.pt.

BRAIT, B. (Org.). Bakhtin: conceitos chaves 1. São Paulo: Contexto, 2005.

BURTON, J. (Org.). The social documentary in Latin America. Pittsburgh: University of Pittsburgh Press, 1990.

CHATTERJI, A. Violent Gods: Hindu nationalism in India's present. Narratives from Orissa. New Delhi: Three Essays Collective, 2009.

CHURCHILL, W. Fantasies of the Master Race: literature, cinema, and the colonization of American Indians. San Francisco: City Lights Books, 1998.

CHOW, R. Primitive Passions: visuality, sexuality, ethnography, and contemporary Chinese cinema. New York: Columbia University Press, 1995. 
CLIFFORD, J. The predicament of culture. Cambridge: Harvard University Press, 1988

CLIFFORD, J.; MARCUS, G. Writing culture: the Poetics and Politics of Ethnography. Oakland: University of California Press, 1986.

CORNER, J.; ROSENTHAL, Allan (Orgs.). New challenges for documentary. Manchester: Manchester University Press, 2005.

COUTINHO, E.; OHATA, M. (Org.). Eduardo Coutinho. São Paulo: Cosac Naify, 2013.

COUTINHO, E. Encontros. Organização de Felipe Bragança. Rio de Janeiro: Beco do Azougue. 2008.

DA-RIN, S. Espelho partido: tradição e transformação do documentário. Rio de Janeiro: Azougue, 2004.

DE GRANDE, A. M. "Sujeitos barrados: a voz do infrator em dez documentários brasileiros.” Dissertação [Mestrado]. Campinas: Unicamp, Instituto de Artes, 2004.

DERRIDA, J. Gramatologia. São Paulo: Perspectiva, 2000.

Limited, Inc. Illinois: Northwestern University Press, 1988.

Margins of philosophy. Chicago: University of Chicago Press, 1982.

Writing and difference. Chicago: The University of Chicago Press, 1978.

DE KOCK, L. "Interview with Gayatri Chakravorty Spivak: New Nation Writers Conference in South Africa”. ARIEL: a review of international English literature. v. 3, n. 23, p. 29-47, 1992.

DELEUZE, G. A imagem-movimento. São Paulo, Brasiliense, 1985.

A imagem-tempo. São Paulo, Brasiliense, 1990.

DOANE, M.-A. “A voz do cinema: a articulação entre corpo e espaço”. In: XAVIER, I. (Org.). A Experiência do Cinema. Rio de Janeiro: Graal, 1983.

ELLIS, J. C. \& MCLANE, B. A. A new history of documentary film. New York: Continuum, 2005.

ESQUENAZI, J.-P. “Quand un produit culturel industriel est-il une ‘Euvre Politique’?” La Découverte, v. 3, n. 167, p. 189-208, 2011. Disponível em: https://www.cairn.info/revue-reseaux-2011-3-page-189.htm. Acessado em: 12 nov. 2018.

FANON, F. Black skins, white masks. New York: Grove Press, 2007. 
FICHMAN, M. Evolutionary theory \& Victorian culture. New York: Humanity Books, 2002.

FISH, S. Is there a text in this class? The authority of interpretive communities. Boston: Harvard University Press, 1980.

FOUCAULT, M. Discipline and punish: The Birth of the Prison. New York: Vintage Books, 1995.

2012.

. “Estratégia, Poder - Saber”. Ditos e escritos IV. São Paulo: Forense Universitária,

Dits e écrits IV. Paris: Gallimard, 1994.

História da sexualidade. São Paulo: Graal, 2001.

1977.

Language, counter-memory, practice. New York: Cornell University Press,

"What is an author?". In: Michel Foucault: aesthetics, method and epistemology. New York: The New Press, 1998.

"On the Genealogy of Ethics: An Overview of Work in Progress". In: Hubert L. Dreyfus and Paul Rabinow, Michel Foucault: beyond structuralism and hermeneutics. 2nd ed. Chicago: University of Massachusetts Press, 1983.

. The archaeology of knowledge. New York: Pantheon Books, 1972.

. The hermeneutics of the subject. New York: Picador, 2005.

. The politics of truth. Cambridge: MIT Press, 2007.

Vigiar e punir. Petrópolis: Vozes, 1987.

FREIRE, M. “Jean Rouch e a voz do Outro no documentário”. Doc On-line, n. 3, pp. 5565., dez. 2007. Disponível em: www.doc.ubi.pt. Acessado em: em 11 out. 2018.

FUSS, D. Essentially Speaking. Londres: Routledge, 1989.

GALINDO, B. “O negro no documentário brasileiro”. In: SILVA, P. H. (Org.). Documentário brasileiro: 100 filmes essenciais. Belo Horizonte: Letramento: Canal Brasil: Abraccine, 2017.

GERVAISEAU, H. A. O Abrigo do tempo: abordagens cinematográficas da passagem do tempo. São Paulo: Alameda, 2012.

GRAHAM, M. Afghanistan in the cinema. Chicago: University of Illinois Press, 2010.

GRIERSON, J. “The Documentary producer”, Cinema quarterly, v. 2, n. 1, p.7-9, 1993. 
Postwar patterns. Hollywood quarterly. v. 1, n. 2, p.161, jan. 1946. Oakland: University of California Press.

HALL, S. A identidade cultural na pós-modernidade. Rio de Janeiro: DP\&A, 2003. . “Encoding/Decoding”. In: DURHAM, M. G. \& KELLNER, D. M. (Eds.). Media and cultural studies: keyworks. Oxford: Blackwell Publishing, 2006.

HALL, S. Representation: cultural representations and signifying practices. London: SAGE Publications Ltd., 1997.

HAMBURGER, E. Políticas da representação: ficção e documentário em Ônibus 174. In: LABAKI, A.; MOURÃO, M.D. (Eds.). O cinema do real. São Paulo: Cosac Naify, 2015.

HARDY, F. (Ed.). Grierson on documentary. Berkeley: University of California, 1966.

HOOKS, b. Black looks: race and representation. Boston: South End Press, 1992.

"Postmodern blackness". In: WILLIAMS, P.; CHRISMAN, L. (Eds.). Colonial Discourse and Postcolonial Theory. New York: Columbia University Press, 1994. pp. 421-427.

Displacing whiteness: essays in social and cultural criticism. Durham: Duke University Press, 1997.

Feminism is for everybody. New York: Routledge, 2000.

Talking back: thinking feminist, thinking black. Boston: South End Press, 1989.

HOFFMAN, B. Inside terrorism. New York: Columbia University Press, 2006.

HUSPEK, M.; RADFORD, G. P. (Eds.). Transgressing discourses: communication and the voice of the other. Albany, NY: State University of New York Press, 1997.

JACOBS, L. “From political activism to women's consciousness”. In: JACOBS, L. (Ed.) The documentary tradition. New York: W.W. Norton, 1979.

JOHNSTON, C. Women's cinema as counter cinema. In: NICHOLS, B. (Ed.), Movies and methods. Oakland: University of California Press, 1976.

JONG, W. et al. Creative documentary: theory and practice. New York: Routledge, 2011.

LABAKI, A. Introdução ao Documentário Brasileiro. São Paulo: Francis, 2006.

LINS, C.; MESQUITA, C. Filmar o real: Sobre o documentário brasileiro contemporâneo. Rio de Janeiro: Zahar, 2008.

LINS, C. O Documentário de Eduardo Coutinho. Rio de Janeiro: Zahar, 2004. 
LYOTARD, J.-F. The postmodern condition: A Report on Knowledge. Minneapolis: University of Minnesota Press, 1984.

MACHUGH, K. "Irony and dissembling: queer tactics for experimental documentary". In: HOLMLUND, C.; FUCHS, C. (Orgs.). Between the sheets, in the streets: queer, lesbian, gay documentary. Minneapolis: University of Minnesota Press, 1997. pp. 224240.

MARGOLIS, J. Redeeming Foucault. In: CAPUTO, J.; YOUNT, M. Foucault and the critique of institutions. Pennsylvania: The Pennsylvania State University Press, 1993.

MARX, K. “O 18 de Brumário de Louis Bonaparte”. In: MARX, K.; Engels, F. Obras escolhidas. Moscou: Progresso, 1982.

MCROBBIE, A. Feminism, postmodernism and the "real me”. In: DURHAM, M. G.; KELLNER, D. M. (Eds.). Media and cultural studies: keyworks. Oxford: Blackwell Publishing, 2006.

MIGLIORIN, C. Ensaios no real: o documentário brasileiro hoje. Rio de Janeiro: Beco do Azougue, 2010.

MOURÃO, M. D.; LABAKI, A. (Org.). O Cinema do real. São Paulo: Cosac \& Naify, 2005.

NICHOLS, B. Engaging cinema: an introduction to film studies. New York: W. W. Norton, 2010.

Introdução ao Documentário. Campinas: Papirus, 2012.

Representing reality: issues and concepts in documentary. Bloomington: Indiana University Press, 1991.

Speaking truths with film: evidence, ethics, politics in documentary. Oakland: University of California Press, 2016.

NIETZSCHE, F. Assim falou Zaratustra. Rio de Janeiro: Civilização Brasileira, 1986.

ODIN, R. "Filme documentário, leitura documentarizante”. Significação. São Paulo, ano v. 39, n. 37, 2012.

PACHECO, L. J. O. O cinema documentário de Miguel Mirra e o Movimento de Documentaristas. O cinema junto aos oprimidos. Dissertação de Mestrado. UFSCar. 2018.

POLYDORO, F. “Uma ontologia dos vídeos amadores de acontecimentos”. Dissertação (Mestrado) - Escola de Comunicações e Artes, Universidade de São Paulo, São Paulo, 2011.

RABINOWITZ, P. They must be represented: the politics of documentary. New York: Verso, 1994. 
RANCIÈRE, J. A partilha do sensível: estética e política. São Paulo: Editora 34, 2009. Le destin des images. Paris: Fabrique, 2009.

. Le spectateur émancipé. Paris: Fabrique, 2009.

. O mestre ignorante. Belo Horizonte: Autêntica, 2002.

RAMOS, F. P.; MIRANDA, L. F. Enciclopédia do cinema brasileiro. São Paulo: Editora Senac, 2000.

. Mas afinal... O que é mesmo documentário? São Paulo: Editora Senac, 2008. Senac, 2005

Teoria contemporânea do cinema - Volumes 1 e 2. São Paulo: Editora

RENOV, M. “Documentary horizons: an afterword”. In: RENOV, M.; GAINES, J. M. (Orgs.). Collecting visible evidence. Minneapolis \& London: University of Minnesota Press, 1999. pp. 313-326.

RENOV, M. (Ed.). Theorizing documentary. New York: Routledge, 1993.

RENOV, M. The subject of documentary. Minneapolis: University of Minnesota Press, 2004.

RIBEIRO, D. O que é Lugar de Fala? Belo Horizonte: Letramento, 2017.

ROTHA, P. Documentary film. Londres: Faber and Faber, 1936.

ROUCH, J. The camera and man. Disponível em: http://www.der.org/jeanrouch/pdf/CameraandMan-JRouch.pdf. Acessado em: 22 mar. 2105.

SAID, E. Humanismo e crítica democrática. São Paulo: Companhia das Letras, 2007.

SAID, E. Orientalism. New York: Vintage, 2003.

SAID, E. The word, the text and the critic. Cambridge: Harvard University Press, 1983.

SALLES, J. M. “A dificuldade do documentário”. In: MARTINS, J. S.; ECKERT, C.; CAIUBY, N. S. (Orgs.). O imaginário e o poético nas ciências sociais. Bauru: EDUSC, 2005.

SERELLE, M. “A ética da mediação: aspectos da crítica da mídia em Roger Silverstone”. Matrizes. v. 10, n. 2, pp. 75-90, maio/ago. 2016.

SHOHAT, E.; STAM, R. Crítica da imagem eurocêntrica. São Paulo: Cosac Naify, 2006. 
SILVA, E. M. "A voz do outro no cinema brasileiro contemporâneo: a questão da primeira pessoa”. Dissertação de Mestrado. Pontifícia Universidade Católica do Rio de Janeiro. 2009.

SILVA, G. S. "Pontos de vista em documentários de periferia: estética, cotidiano e política”. Tese (Doutorado) - Escola de Comunicações e Artes, Universidade de São Paulo, São Paulo, 2011.

SILVA, M. "Ponto de vista a(u)torizado: composições da autoria no documentário brasileiro contemporâneo". Tese (Doutorado) - Escola de Comunicações e Artes, Universidade de São Paulo, São Paulo, 2013.

SOARES, R. L. Margens da comunicação: discurso e mídias. São Paulo: Annablume Editora, 2009.

. "De palavras e imagens: estigmas sociais em discursos audiovisuais”. E-

Compós - Revista da Associação Nacional dos Programas de Pós-Graduação em Comunicação. Brasília, v. 12, n. 1, 2009.

"Pequeno inventário de narrativas midiáticas: verdade e ficção em discursos audiovisuais”. Significação - Revista de Cultura Audiovisual. São Paulo, n. 34, p. 5572, 2010.

SONTAG, S. Regarding the pain of others. New York: Picador, 2003.

SPIVAK, G. S. “Can the subaltern speak?”. In: WILLIAMS, P.; CHRISMAN, L. (Eds.). Colonial discourse and postcolonial theory. New York: Columbia University Press, 1994. pp. 421-427. Colonial discourse and postcolonial theory. New York: Columbia University Press, 1994. pp. 66-111.

SPIVAK, G. C. “Can the Subaltern Speak?” In: GROSSBERG, Lawrence et al. (Org.). Marxism and the interpretation of culture. London: Macmillan Education, 1988. p. 271-315.

SPIVAK, G. S. Other Asias. Malden, MA: Blackwell Publishing, 2008.

SPIVAK, G. C. The post-colonial critic: interviews, strategies, dialogues. HARASYM, S. (Org.). New York: Routledge, 1990.

STAM, R.; SHOHAT, E. “Teoria do Cinema e espectorialidade na era dos 'pós””. In: RAMOS, F. P. (Org.), Teoria contemporânea do cinema, V. II. São Paulo: Editora Senac São Paulo, 2005. pp. 393-424.

TEIXEIRA, F. E. (Org.). Documentário no Brasil: tradição e transformação. São Paulo: Summus, 2004.

THOMAIDIS, K. Theatre \& voice. London: Plagrave, 2017. 
TORGOVNICK, M. Gone primitive: savage intellects, modern lives. Chicago: University of Chicago Press, 1990.

WAUGH, T.; BRENDAN, M. B.; WINTON, E. (Eds.). Challenge for change: activist documentary at the National Film Board of Canada. McGill-Queen's University Press, 2010.

WILLIAMS, R. Marxism and literature. Oxford: Oxford University Press, 1987.

WINSTON, B. Claiming the real: the documentary film revisited. Londres: British Film Institute, 1995.

WOLFE, C. "Historicising the 'Voice of God': the place of vocal narration in classical documentary”. Film History, v. 9, n. 2, pp. 149-167, 1997. JSTOR, Diseponível em: www.jstor.org/stable/3815172.

XAVIER, I. "Indagações em torno de Eduardo Coutinho e seu diálogo com a tradição moderna”. In: MIGLIORIN, C. Ensaios no real: o documentário brasileiro hoje. Rio de Janeiro: Beco do Azougue Editorial, 2010. pp. 65-80.

"O Olhar e a voz: a narração multifocal do cinema e a cifra da História em São

Bernardo”. Literatura e Sociedade: Revista de Teoria Literária e Literatura Comparada. São Paulo, n. 2, p. 126-38, 1997.

O Discurso cinematográfico: a opacidade e a transparência. São Paulo: Paz e Terra, 2012.

\section{FILMOGRAFIA}

A guerra invisível (Direção Kirby Dick, 2012).

A negação do Brasil - O Negro na Telenovela Brasileira (Direção Joel Zito Araújo, 2000).

A pessoa é para o que nasce (Direção Roberto Berliner, 2005).

Arraial do Cabo (Direção Mário Carneiro e Paulo César Saraceni, 1959).

Aruanda (Direção Linduarte Noronha, 1959).

Berlin: sinfonia de uma metrópole (Direção Walther Ruttmann, 1927).

Crônicas de um verão (Direção Jean Rouch e Edgar Morin, 1961).

Brains on toast: the Inexact science on gender (Direção Joyan Saunders, 1992).

Edifício Master (Direção Eduardo Coutinho, 2002).

Em nome do meu povo (Direção Rodrigo Guim, 2018).

Eu não sou seu negro (Direção Raoul Peck, 2016).

Eu, um negro (Direção Jean Rouch, 1958).

Espero tua (re)volta (Direção Eliza Capai, 2018).

Falcão - meninos do tráfico (Direção MV Bill, 2006).

Here in the Southwest (Direção Joyan Saunders, 1984).

Hospital (Direção Frederick Wiseman, 1970).

Housing problems (Direção Edgar Anstey e Arthur Elton, 1935).

How the myth was made: a study of Robert Flaherty's Man of Aran (Direção George Stoney e James Brown, 1984). 
Ilha das Flores (Direção Jorge Furtado, 1989).

Jaguar (Direção Jean Rouc, 1967).

Let there be light (Direção John Huston, 1946).

Leve-Me pra sair (Direção Alana Menk, Babi Sonnewend, Jessica Puga, José Agripino e Juily Manghirmalani, 2013).

Maioria absoluta (Direção Leon Hirszman, 1964).

Nada além das horas (Direção Alberto Cavalcanti, 1926).

Nana, mom, and me (Direção Amalie Rothschild, 1974)

Nanook of the North (Direção Robert Flaherty, 1922).

Notícias de uma guerra particular (Direção João Moreira Salles e Kátia Lund, 1999).

O fim e o princípio (Direção Eduardo Coutinho, 2006).

O homem de Aran (Direção Robert Flaherty, 1934)

O prisioneiro da grade de ferro (Direção Paulo Sacramento, 2003).

Ônibus 174 (Direção José Padilha, 2000).

Primary (Direção Robert Drew, 1960).

Santiago (Direção João Moreira Salles, 2007).

Sweetgrass (Direção Lucien Castaing-Taylor e Ilisa Barbash, 2009).

Terra sem pão (Direção Luis Buñuel, 1933).

Titicut follies (Direção Frederick Wiseman, 1967).

The thin blue line (Direção Errol Morris, 1988).

Tongues untied (Direção Marlon Riggs, 1989).

Two laws (Direção Alessandro Cavadini e Carolyn Strachan, 1982).

Wai'á e o mundo Xavante (Direção Rodrigo Guim, 2000).

Why we fight (Direção Eugene Jarecki, 2015). 